\title{
GÊNESE DAS OCORRÊNCIAS DE ARENITO ASFÁLTICO DA BORDA LESTE DA BACIA DO PARANÁ, SP
}

\author{
CARLOS CÉSAR DE ARAÚJO
}

Orientador: Prof. Dr. Jorge Kazuo Yamamoto

TESE DE DOUTORAMENTO

COMISSÃO JULGADORA

Nome

Presidente: Prof. Dr. Jorge Kazuo Yamamoto

Examinadores: Dr. Flávio Luís Fernandes

Prof. Dr. Jorge Alberto Trigüis

Prof. Dr. Sidnei Pires Rostirolla

Prof. Dr. Walter Malagutti Filho

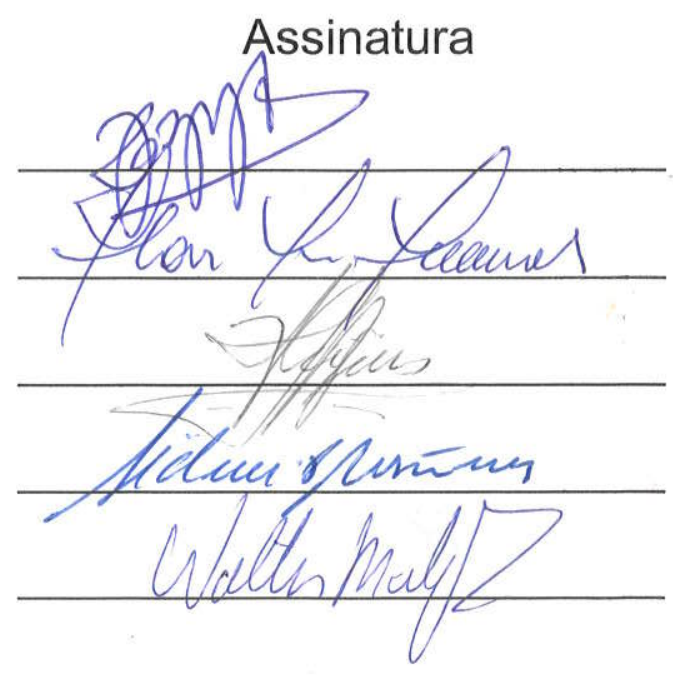

SÃO PAULO

2003 
UNIVERSIDADE DE SÃO PAULO

INSTITUTO DE GEOCIÊNCIAS
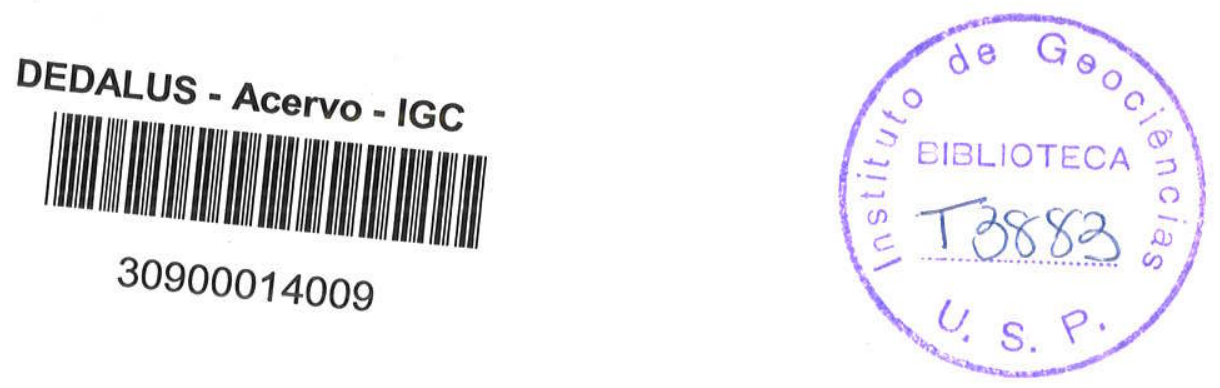

\section{GÊNESE DAS OCORRÊNCIAS DE ARENITO ASFÁLTICO DA BORDA LESTE DA BACIA DO PARANÁ, SP.}

Carlos César de Araújo

Orientador: Prof. Dr. Jorge Kazuo Yamamoto

Co-orientador: Prof. Dr. Sidnei Pires Rostirolla

TESE DE DOUTORAMENTO

Programa de Pós-Graduação em Geologia Sedimentar

SÃO PAULO

2003 


\section{Agradecimentos}

Este trabalho foi possível somente com o apoio da Fapesp, por intermédio da bolsa de doutorado e auxílio à pesquisa (processos 99/10417-7 e 00/01852-0).

Várias pessoas me ajudaram durante a execução da pesquisa, se esqueço alguém nos agradecimentos é porque a memória me trai, mas em meu coração sou grato a todos.

Agradeço ao Instituto de Geociências da USP pelo apoio institucional.

Agradeço ao Prof. Dr. Jorge Kazuo Yamamoto, orientador, pelo incrivel incentivo e apoio científico na forma de discussão dos assuntos e revisão do texto. Sua postura como pesquisador é exemplar.

Agradeço ao co-orientador Prof. Dr. Sidnei Pires Rostirolla pelas sugestões dadas ao longo do desenvolvimento do trabalho e também pela participação em cursos e excursões de campo da Universidade Federal do Paraná.

Agradeço ao Prof. Dr. Thomas Rich Fairchild, coordenador de pós-graduação, pelo apoio acadêmico e pelas sugestões ao abstract.

Agradeço ao Prof. Dr. Paulo Veneziani pela importante ajuda com a interpretação morfoestrutural da área.

Ao Prof. Francisco José Fonseca Ferreira pela cessão dos dados geofísicos.

Agradeço ao Prof. Dr. Ginaldo Adhemar da Cruz Campanha pelas discussões sobre os aspectos estruturais da área.

Aos Profs. Walter Malagutti e João Carlos Dourado do IGCE-UNESP pelo apoio aos levantamentos gravimétricos de campo, assim como agradeço ao Francisco Manoel Garcia Barrera, o Paco, pela ajuda nos trabalhos de campo. Ao Maximillian Forlin, o Max, pela ajuda nos trabalhos de levantamento gravimétrico.

Ao Prof. Dr. Nelsi Cogo de Sá, do IAG-USP, pela cessão dos dados gravimétricos e programa de redução e ao Prof. Dr. Éder Cassola Molina pelo auxílio com a entrada e processamento dos dados.

Também agradeço ao Carlos Alberto Birelli e Vicente Luiz Galli, ambos do IPT, pelo apoio ao levantamento magnetométrico de campo.

Agradeço ao Prof. Paulo César Fonseca Gianinni pela discussão de vários temas em sedimentologia e estratigrafia e também ao Isaac Jamil, à Bruna e ao Douglas pelo apoio na utilização dos equipamentos do Laboratório de Petrografia Sedimentar.

Agradeço ao grupo do Centro de Pesquisas Geocronológicas, à Ivone Sonoki e à Helen Sonoki pela importante ajuda com a compilação dos dados geocronológicos e ao Artur Onoe pela colaboração no trabalho de laboratório. Ao Vasco pela ajuda na preparação das amostras.

Ao Prof. Dr. Paulo Roberto Santos por ter cedido os perfis geológicos e pelas sugestões. 
Agradeço ao Henrique, ao Claudionor, ao José pela ajuda nos trabalhos do dia a dia na gráfica.

Agradeço ao Jaime de Souza Marcos pelo auxílio com as cópias das fotografias aéreas. Ao Prof. Dr. Ailton Luchiari do Laboratório de Aerofotogeografia e Sensoriamento Remoto, FFCLH/USP, por gentilmente ter cedido as fotos aéreas utilizadas neste estudo.

Aos Profs. Fábio Taioli e José Domingos Faraco Gallas pelas sugestões sobre os trabalhos de geofísica.

Ao Prof. Claudio Riccomini pelas sugestões dadas na qualificação.

Ao Prof. Jorge Hachiro pela ajuda com algumas referências bibliográficas. Agradeço ao Prof. Jorge Triguis por gentilmente ter enviado cópia de sua tese de doutorado.

Ao Marcelo Rocha pela ajuda com os problemas de informática, e à Veridiana Martins pelas sugestões ao texto. Agradeço à Liliane Janikian e ao Renato Paes de Almeida pelas discussões e sugestões.

Ao Sílvio Luis pela ajuda com as amostras e trabalho de campo. Agradeço ao Thiago Piacentini pela ajuda no trabalho de campo.

Ao André Oliveira Sawakuchi pelo auxílio no trabalho de campo e discussões sobre estratigrafia e sedimentologia.

Ao Sérgio Vicente Liotte, velho amigo, pelo ajuda no trabalho de magnetometria e pela digitalização de mapas.

Agradeço a Bárbara Lipski da UFPR pela presteza nas discussões acerca da análise estrutural em bacias sedimentares e trabalho de campo. Do mesmo modo, agradeço ao Prof. Dr. Fernando Alkmin da UFOP pela atenção e sugestões para detecção das estruturas em campo.

Agradeço ao Sr. Augustinho Gonçalves e esposa, de Anhembi, pela paciência com que me receberam em sua propriedade inúmeras vezes. Do mesmo modo, agradeço ao $\mathrm{Sr}$. Takao de Piapara que do mesmo modo foi muito hospitaleiro.

Ao Ericsson Zanon da seção de informática pela ajuda com o scanner e outros equipamentos.

Aos funcionários da biblioteca do Instituto de Geociências, em especial à Brenda Maria Mascarenhas pela presteza constante.

Às secretárias da seção de pós-graduação Ana Paula Cabanal Pentagna, Magali Polli Fernandes Rizzo e ao Thadeu Caggiano pela ajuda e empenho em resolver o trabalho burocrático.

Um especial agradecimento à Vanessa Madrucci pelo apoio constante e entusiasmo pelo trabalho. Sua contribuição foi significativa para a conclusão da tese.

E finalmente agradeço ao Marcos, meu irmão, e à Orbélia, minha mãe, pelo apoio incondicional ao longo de todos estes anos. 


\section{Sumário}

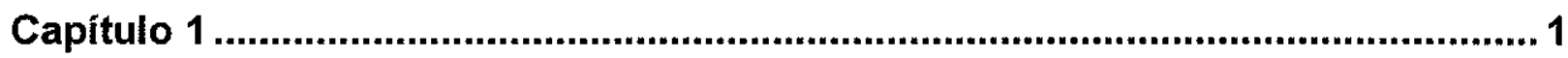

Introdução .................................................................................................................. 1

1.1 Importância dos arenitos asfálticos (econômica e científica) ........................................2

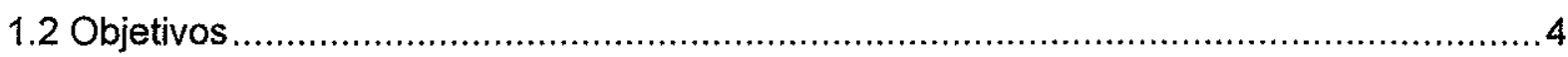

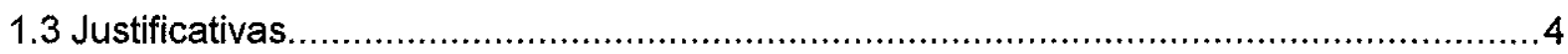

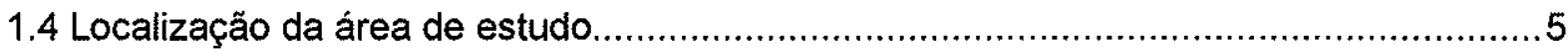

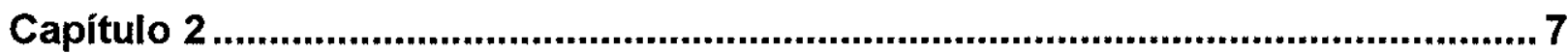

Dados anteriores ................................................................................................ 7

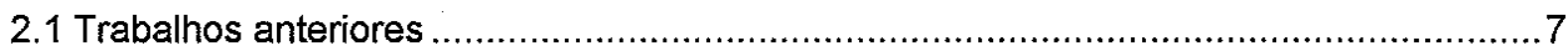

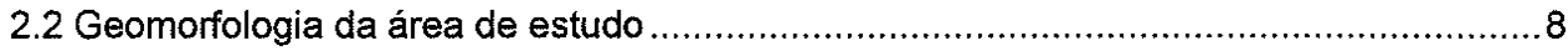

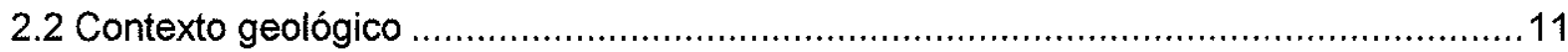

2.3 Bacia do Paraná - sedimentação, estratigrafia e tectônica .....................................13

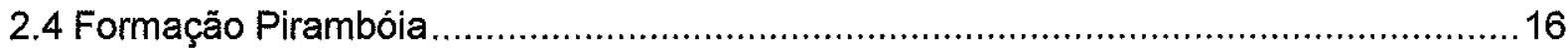

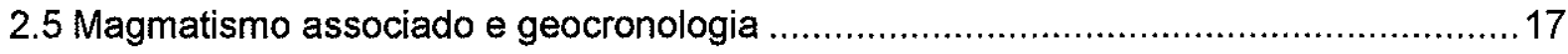

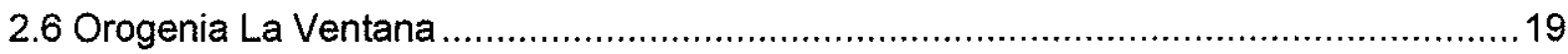

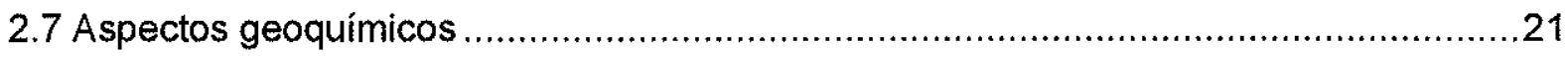

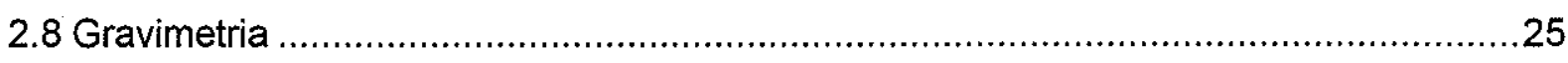

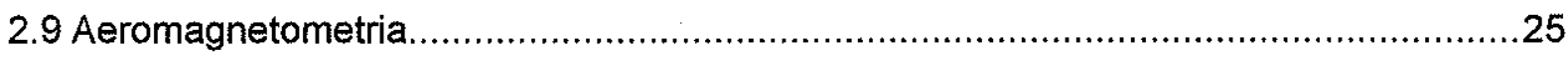

Capítulo 3 ................................................................................................... 27

Materiais e métodos ........................................................................................... 27

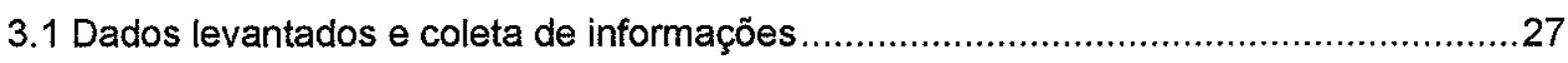

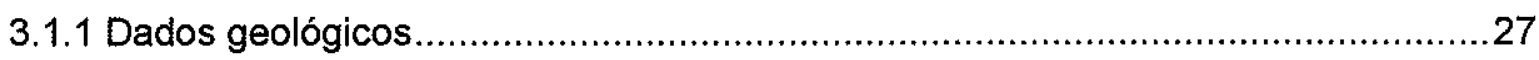

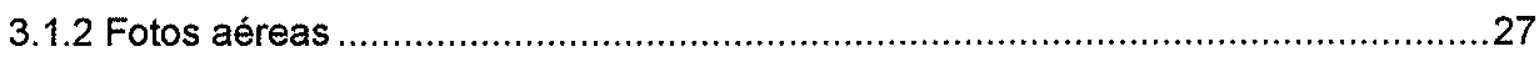

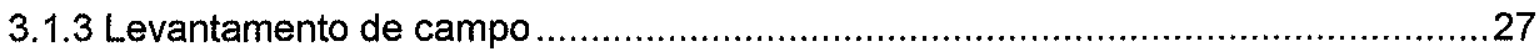

3.2 Base planialtimétrica e digitalização de dados topográficos ..................................28

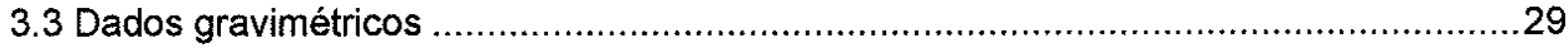

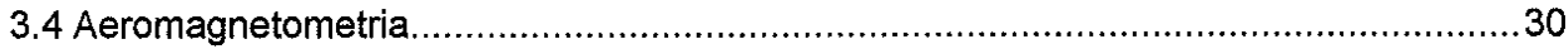

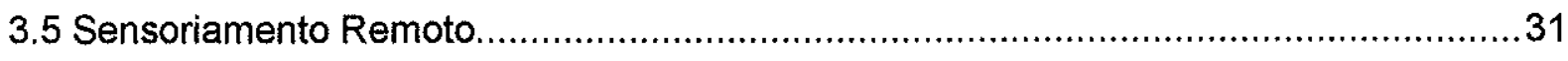

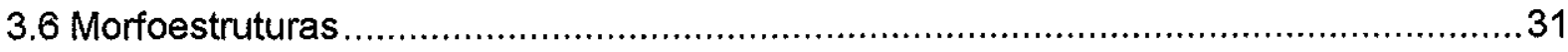

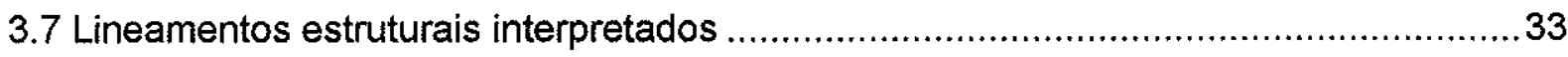

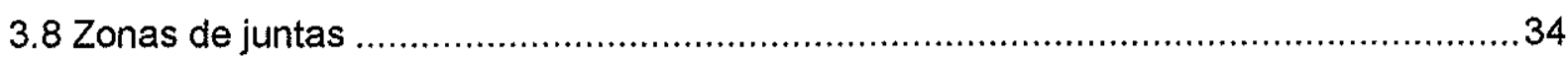

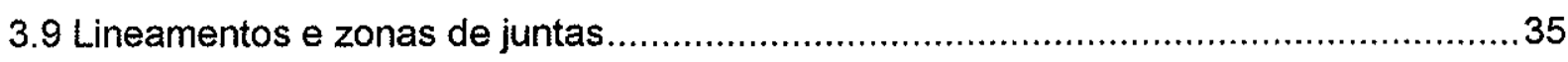

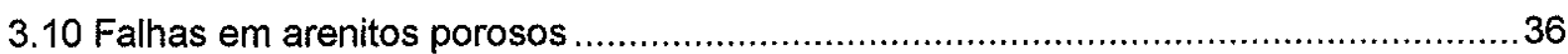

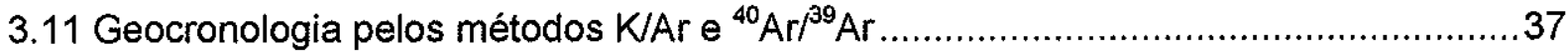




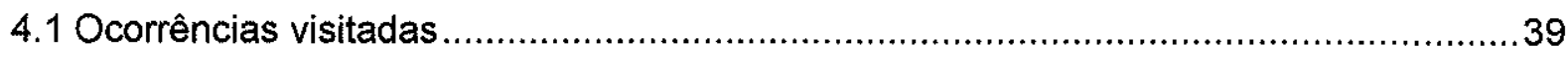

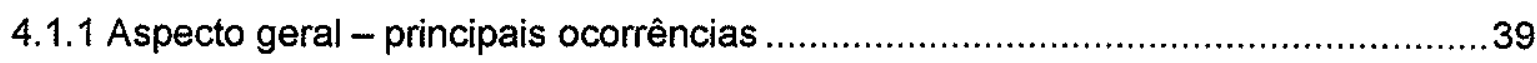

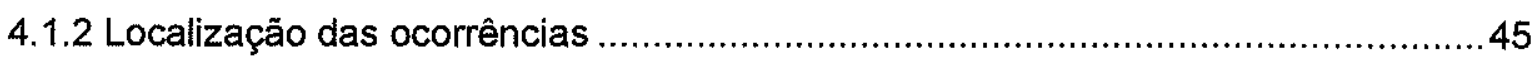

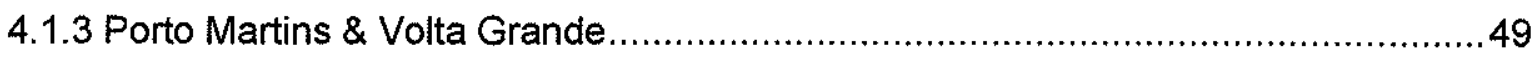

4.1.4 Betumita, Moquém e Moquém II................................................................49

4.1.5 Morro do Bofete, Fazenda São Jorge, Bairro da Mina e Estrada da Mina ............52

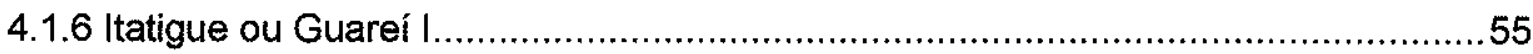

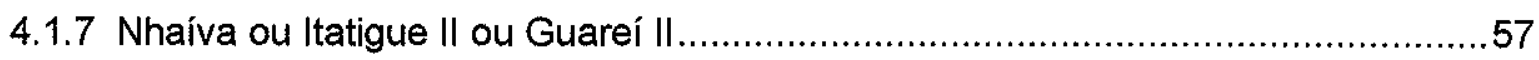

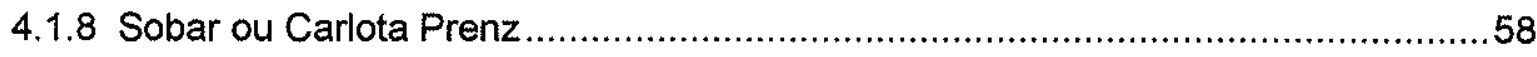

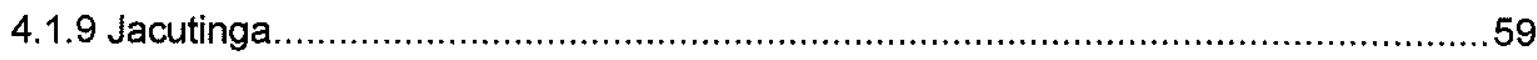

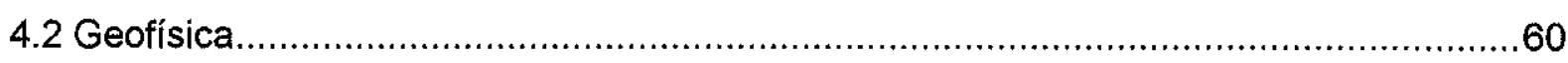

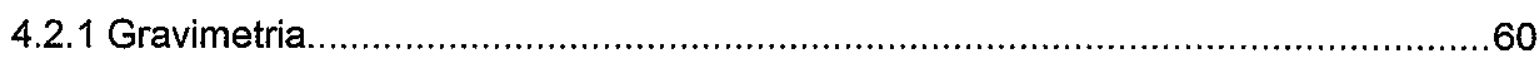

4.2.1.1 Interpretação de dados gravimétricos................................................65

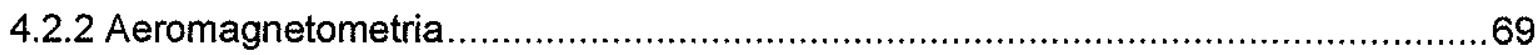

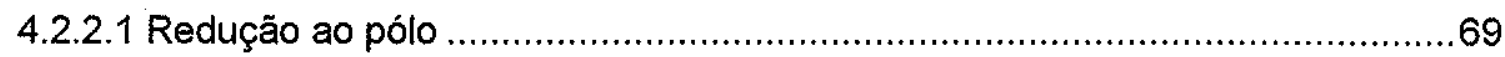

4.2.2.2 Micronivelamento e Filtragem direcional................................................ 70

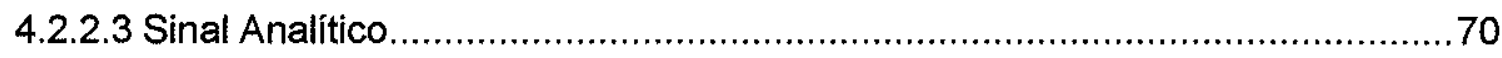

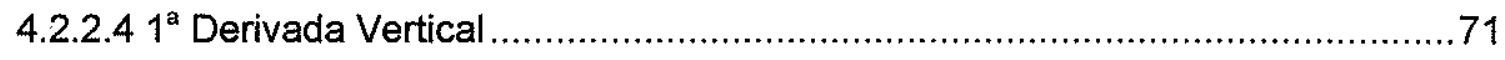

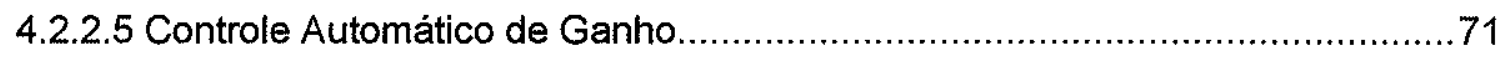

4.2.2.6 Interpretação de dados aeromagnéticos............................................. 71

4.2.3 Magnetometria terrestre .......................................................................... 75

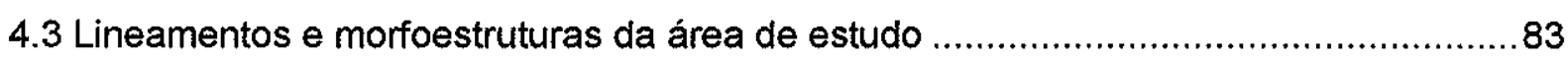

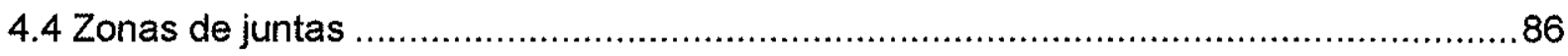

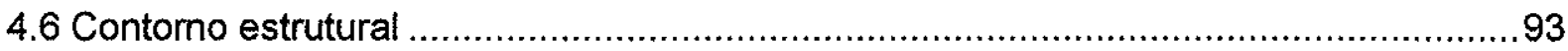

4.9 Tectonismo deformador na área de ocorrência de arenito asfáltico...........................95

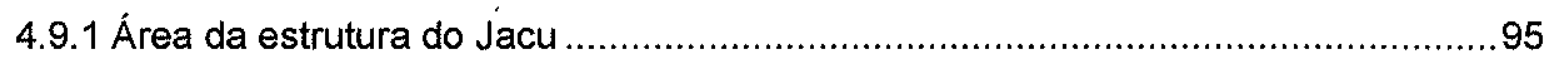

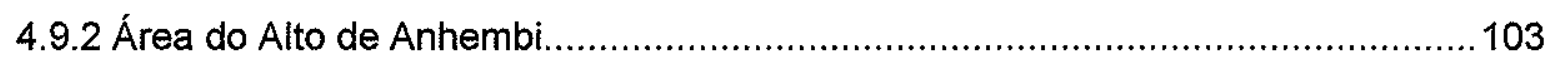

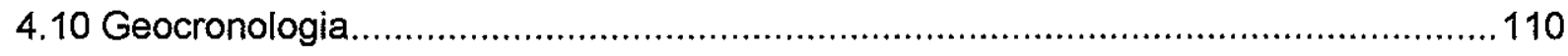

4.11 Observações geológicas acerca da área de estudo .........................................116

4.12 Posicionamento espacial das ocorrências e o magmatismo associado................... 118

4.13 Gênese dos arenitos asfálticos ............................................................... 120

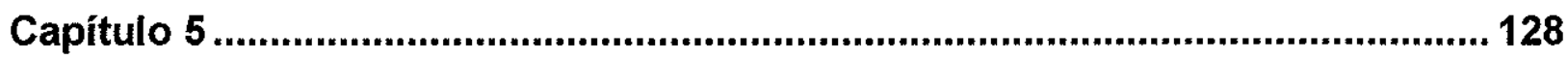

Considerações fínais..................................................................................... 128

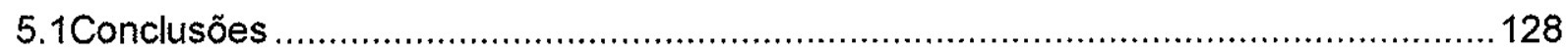

Referências bibliográficas .......................................................................... 130 


\section{Lista de figuras}

Figura 1.1: Localização da área de estudo.

6

Figura 2.1: (A) Contexto geomorfológico e (B) modelo numérico de terreno (MNT). Ocorrências: 1 - Porto Martins; 2 - Volta Grande; 3 - Braço da Represa; 4 - Betumita; 5 Moquém I; 6 - Moquém II; 7 - Piapara; 8 - Morro do Bofete; 9 - Fazenda São Jorge; 10 Estrada da Mina; 11 - Bairro da Mina; 12 - Bairro da Mina II; 13 - Estrada da Mina II; 14 Nhaíva; 15 - Sobar; 16 - Sobar II; 17 - Itatigue; 18 - Jacutinga......................................... 10 Figura 2.2: Litoestratigrafia da área de estudo. ............................................................ 12 Figura 2.3: Elementos estruturais da Bacia do Paraná, Brasil (modificado de Zalan, 1991; CPRM, 2001a e b)................................................................................................. 15

Figura 2.4: Sumário das datações geocronológicas disponíveis na região de estudo. ...........18 Figura 2.5: Esboço geológico da porção centro-atlântica da Argentina. (1) Plutonismo Paleozóico; (2) Cobertura sedimentar (Pré-cambriana nas Sierras Setentrionales, Paleozóica Inferior no nordeste da Patagônia e Siluro-Neopaleozóica nas Sierras Australes); (3) Embasamento cristalino Pré-cambriano. (Modificado de Cobbold et al., 1986 e Rosselo et al.,

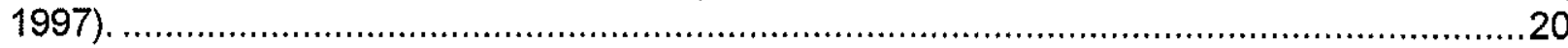

Figura 2.6: Comparação entre cromatogramas........................................................22 Figura 2.7: Mapa de volume de hidrocarbonetos disponíveis para migração $\left(\mathrm{m}^{3} / \mathrm{km}^{2}\right)$. A área de estudo está assinalada pelo retângulo preto (Segundo Araújo et al. 2000) .....................24

Figura 3.1: Articulação das cartas topográficas $1: 50.000$ utilizadas. .................................28

Figura 3.2: Esquema de traçado de morfoestruturas (linhas vermelhas) ............................32

Figura 4.1: Detalhes das amostras de mão do arenito asfáltico. ......................................40

Figura 4.2: Imagens de amostras de arenito asfáltico em lâminas delgadas........................41

Figura 4.3:Tipo de contatos de grãos observados em lâminas delgadas, amostras de arenito asfáltico.

.42

Figura 4.4: Imagens da lâmina de arenito asfáltico do Morro do Bofete utilizadas para

determinação de porosidade .................................................................................44

Figura 4.5: Localização das principais ocorrências e geologia da área. .............................46 46

Figura 4.6: Detalhe da localização das principais ocorrências de arenitos asfálticos. (A) Porto Martins \& Volta Grande; (B) Betumita \& Moquém; (C) Morro do Bofete; (D) Nhaíva \& Itatigue; (E) Sobar; (F) Jacutinga. Imagem Landsat 7 ETM+ banda pancromática de 29 de novembro de 1999.

Figura 4.7: Lavra abandonada na ocorrência Betumita. Observa-se estratificações cruzadas de grande porte preenchidas por hidrocarbonetos.......................................................50

Figura 4.8: Instalações de britagem do arenito asfáltico da mina Betumita. ..............................51

Figura 4.9: Esboço geológico das ocorrências do Morro do Bofete.....................................53

Figura 4.10: Fraturamento na ocorrência Morro do Bofete. (A) Padrão de fraturamento NW/NE. (B) Detalhe de fraturas geradas a partir de bandas de deformação, indicadas pelas setas. (C) Bandas de deformação não preenchidas por hidrocarbonetos. .........................54

Figura 4.11: Perfil geológico esquemático na área do Morro do Bofete. ...............................55

Figura 4.12: Esboço geológico das ocorrências de Itatigue e Nhaiva................................56

Figura 4.13: Aspecto da ocorrência Itatigue. Alternância do preenchimento por hidrocarbonetos em camadas eólicas $e$ de interdunas...................................................56

Figura 4.14: Aspecto do arenito asfáltico, ocorrência Nhaíva. (A) Estratificações cruzadas preenchidas por óleo, aspecto listrado. (B) Peturbação das estratificações, evidenciada pelo preechimento por hidrocarbonetos, na forma de canais centimétricos...............................57 Figura 4.15: Esboço geológico da ocorrência do Sobar. As ocorrências localizam-se próximo à área de afloramento da $\mathrm{Fm}$. Teresina, na região do Domo de Carlota Prenz.....................58 Figura 4.16: Distribuição dos pontos de leitura de observações gravimétricas - área Jacu. Imagem ETM+ Landsat 7 banda pancromática, coordenadas em metros........................61 Figura 4.17: Distribuição dos pontos de leitura de observações gravimétricas - área Anhembi. Imagem ETM+ Landsat 7 banda pancromática, coordenadas em metros. 
Figura 4.18: Mapa de anomalia - Bouguer - área Jacu. ...............................................63

Figura 4.19: Mapa de anomalia Bouguer - área Anhembi. ...........................................63

Figura 4.20: Mapa de anomalia Bouguer - levantamentos sobrepostos. ..............................64

Figura 4.21: Mapas de resíduos de grau 1 da anomalia Bouguer. ......................................65

Figura 4.22: Gravimetria regional. A) Gravimetria regional Bouguer; (B) Resíduo de $1^{0}$ grau;

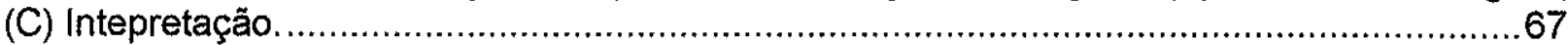

Figura 4.24: Imagens gravimétricas e interpretação na área do Alto Estrutural de Anhembi. (A)

Campo total; (B) Resíduo de $1^{\circ} \mathrm{grau} ;(\mathrm{C})$ Interpretação. ...............................................68

Figura 4.25: Aeromagnetometria, campo total. ......................................................... 72

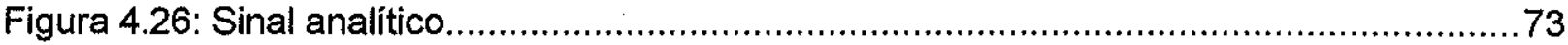

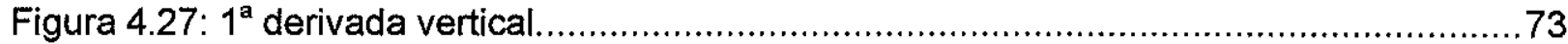

.

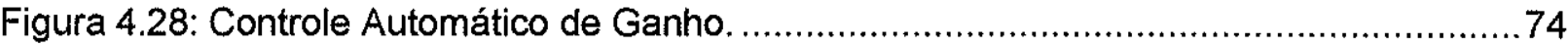

Figura 4.29: Interpretação de lineamentos magnéticos.............................................74

Figura 4.30:Apresentação dos mapas magnéticos e interpretações dos alvos na porção norte da área de estudo: Mina Betumita, Moquém e Braço da Represa. ...................................77

Figura 4.31: Apresentação dos mapas magnéticos e interpretações dos alvos na porção sul da área de estudo: Morro do Bofete, Nhaíva, Itatigue e Sobar............................................78

Figura 4.32: Comparação entre campo total e sinal analítico - Betumita. .............................79

Figura 4.33: Comparação entre campo total e sinal analítico - Moquém. ............................79

Figura 4.34: Comparação entre campo total e sinal analítico - Braço da Represa.................80

Figura 4.35: Comparação entre campo total e sinal analítico - Morro do Bofete................... 81

Figura 4.36: Comparação entre campo total e sinal analítico - Nhaíva.............................. 82

Figura 4.37: Comparação entre campo total e sinal analítico - Sobar..............................82

Figura 4.38: Comparação entre campo total e sinal analítico - Itatigue. .............................83

Figura 4.39: Rede de drenagem. .......................................................................... 84

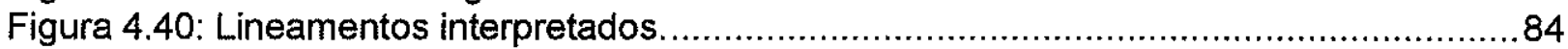

Figura 4.41: Mapa morfoestrutural. Os maiores valores correspondem a altos morfoestruturais, os menores valores correspondem a baixos morfoestruturais. ................. 85

Figura 4.42: Feições retilíneas de drenagem interpretadas e mapas de densidade.............87

Figura 4.43: Mapa com divisão estratigráfica utilizada para separação de juntas. ................89

Figura 4.44: Roseta do conjunto total de feições retilíneas de drenagem. ..........................91

Figura 4.45: Rosetas de feições retilíneas de drenagem por período geológico. .................92

Figura 4.46: Contorno estrutural (Fm. Teresina). Ocorrências: 1 - Porto Martins; 2 - Volta Grande; 3 - Braço da Represa; 4 - Betumita; 5 - Moquém I; 6 - Moquém II; 7 - Piapara; 8 Morro do Bofete; 9 - Fazenda São Jorge; 10 - Estrada da Mina; 11 - Bairro da Mina; 12 Bairro da Mina II; 13 - Estrada da Mina II; 14 - Nhaíva; 15 - Sobar; 16 - Sobar II; 17 Itatigue; 18 - Jacutinga........................................................................................ 94 Figura 4.47: Rosetas de falhas. (A) Roseta dos lineamento interpretados em imagens de satélite e MNT; (B) Falhas NE sinistrais; (C) Falhas NW dextrais. .....................................96 Figura 4.48: Exemplos de indicadores cinemáticos. (a) Bandas de deformação; (b) Fraturamento ................................................................................................. 96 Figura 4.49: Lineamentos interpretados e rosetas de sistemas de fraturamento na área da estrutura do Jacu. ................................................................................................ 97 Figura 4.50: Diques clásticos e pólos das orientações. (A) Diques clásticos, $2,5 \mathrm{~km}$ SW de Porangaba (E791764, N7433165); (B) Diques clásticos, 2,0 km NE de Torre de Pedra (E789872, N7427098); (C) Diques clásticos, 5,0 km NE de Guareí, Espigão da Areia Branca (E791607, N7416907). (D) Pólos das orientações de 12 diques clásticos medidos nos pontos A, B e C. .98

Figura 4.51:Falhas pós-deposicionais na Formação Teresina encontradas na região do Jacu. (CC560) Fazenda São Jorge (E784959, N7431189); (CC597, CC597a) Estrada BofetePorangaba (E789086, N7440083) .................................................................99

Figura 4.52: Mapa de contorno estrutural da Fm. Teresina, área da estrutura do Jacu. 1Morro do Bofete I II e III; 2 - Faz. S. Jorge I e II; Estrada da Mina; Bairro da Mina I, II e III; 5 Nhaíva; 6 - Itatigue; 7 - Sobar I, II e III; 8 - Jacutinga. 
Figura 4.53: Diagrama com as diferentes evidências estruturais e componentes relacionados às hipóteses de gênese do arenito asfáltico na área do Domo do Jacu. (A) Diagrama de falha oblíqua dextral na área da ocorrência do Morro do Bofete. (B) Falhas normais relacionadas à região de alívio. (C) Banda de deformação no reservatório Pirambóia. (D) Banda de Deformação na ocorrência de arenito asfáltico. (E) Imagem ETM+ Landsat Pancromática com indicação da falha oblíqua dextral e dos lineamentos NE, diques de rocha básica e ocorrência estão assinalados. (F) Esboço geológico da porção leste da estrutura do Jacu com várias ocorrências, diques de rochas básicas, falhas e lineamentos. (G) Modelo de Riedel comparado aos elementos presentes na imagem de satélite e mapa geológico................. 102 Figura 4.54: Principais indicadores cinemáticos encontrados na região de Anhembi. (A) Fraturas escalonadas em siltitos da Fm. Teresina, ponto CC279; (B) Estrias em siltitos da Fm. Teresina, ponto CC585; (C) Banda de deformação em arenito da Fm. Pirambóia, ponto CC444; (D) Estrias em arenito com "filme" de óxidos de ferro, ponto CC444.....................104 Figura 4.55: Rosetas de falhas e lineamentos. (A) Roseta das falhas NE sinistrais e falhas NW sinistrais; $(B)$ roseta dos lineamentos interpretados em imagens de satélite, MNT e rede de drenagem. 105 Figura 4.56: Estereogramas das lineações e planos correspondentes encontrados na região de Anhembi. 106 Figura 4.57: Mapa de contorno estrutural da Formação Teresina na região do Alto de Anhembi. Ocorrências: 1 - Porto Martins; 2 - Volta Grande; 3 - Braço da Represa; 4 Betumita; 5 - Moquém I; 6 - Moquém II; 7 - Piapara; 8 - Faz. Ribeirão Claro................... 107 Figura 4.58: Bandas de deformação encontradas na ocorrência Betumita (CC199). (A)Zona de Banda de deformação com rejeito aparente de $10 \mathrm{~cm}$; (B) Detalhe do rejeito; (C); Estrias no plano de falhamento; (D) Fotografia em lupa com aumento de $6 x$, cimentação silicosa de grãos na banda de deformação com ausência de hidrocarbonetos. ................................. 108 Figura 4.59: Esboço geológico com lineamentos intepretados e rosetas de sistemas de fraturamento na área do alto estrutural de Anhembi. ..................................................109 Figura 4.60: Localização das amostras de rochas básicas utilizadas para datação KJAr e $\mathrm{Ar}^{40} / \mathrm{Ar}^{39}$ 110

Figura 4.61: Exemplo de felspato alterado em diabásio da amostra CC252.

Figura 4.62: Espectro de liberação de gás para os 3 grãos de rocha total da amostra CC11y.

Figura 4.63: Ideograma da amostra $\mathrm{CC11y}$ com freqüencia de análises, razão $\mathrm{Ca} / \mathrm{K} e$ quantidade de gás disponivel (Moles de ${ }^{39} \mathrm{Ar}$ ).

Figura 4.64: Espectro de liberação de gás para os 3 grãos de rocha total da amostra CC236.

Figura 4.65: Ideograma da amostra $\mathrm{CC} 236 \mathrm{com}$ freqüencia de análises, razão $\mathrm{Ca} / \mathrm{K}$ e quantidade de gás disponível (Moles de ${ }^{39} \mathrm{Ar}$ ). 115

Figura 4.66: Ideograma e espectro de liberação de gás da amostra CC246e com freqüência de análises, razão $\mathrm{Ca} / \mathrm{K}$ e quantidade de gás disponível (Moles de ${ }^{39} \mathrm{Ar}$ )...... 115

Figura 4.67: Principais elementos presentes nas ocorrências de arenito asfáltico e indicação dos principais caminhos de migração.

Figura 4.68: Principais elementos relacionados à gênese do arenito asfáltico.

Figura 4.69: Quadro de eventos - arenitos asfálticos. Principais elementos e cronologia relacionados a gênese dos arenitos asfálticos na borda leste da Bacia do Paraná (Adaptado a partir de Araújo et al. 2000).

Figura 4.70: Quadro de eventos - Sistema petrolífero Irati-Pirambóia. Relações dos elementos e processos essenciais, assim como o tempo de preservação e momentos críticos do sistema petrolífero Permiano da Bacia do Paraná (Retirado de Araújo et al. 2000).......124 


\section{Lista de tabelas}

Tabela 1: Recursos recuperáveis de arenito asfáltico no mundo. Campbell (1997 apud OSRRN, 2003) 3

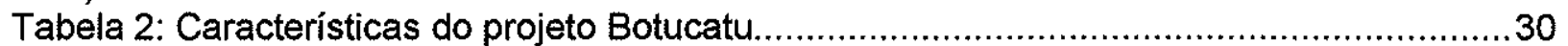

Tabela 3: Observações em lâmina delgada. ................................................................43

Tabela 4: Porosidade do arenito asfáltico medida em lâmina delgada, Morro do Bofete........43

Tabela 5: Localização das ocorrências de arenitos asfálticos. .......................................45

Tabela 6: Parâmetros de redução ao pólo dos dados magnéticos......................................69

Tabela 7: Sumário dos dados de medição magnética terrestre.........................................75

Tabela 8: Ocorrências de arenitos asfálticos e valores de densidade de zonas de junta. ......90

Tabela 9: Tipos litoestratigráficos utilizados na separação das zonas de juntas. ..................90

Tabela 10: Feições lineares de drenagem por período geológico ......................................91

Tabela 11: Datações em amostras de basaltos e diabásios da área de estudo. .................111 
Resumo

Foram estudadas as ocorrências de arenitos asfálticos da borda leste da Bacia do Paraná, Estado de São Paulo (SP), para o desenvolvimento de um modelo genético. Estas ocorrências têm sido estudadas desde o século 19, entretanto nunca foi proposto um modelo para sua gênese. Este trabalho apresenta um modelo genético baseado na análise integrada de dados espaciais em um banco de dados composto de dados morfoestruturais, modelo numérico de terreno (MNT), trabalho de campo, datação geocronológica, magnetometria terrestre e aérea, sensoriamento remoto e dados gravimétricos.

Como resultado, concluiu-se que o melhor modelo relaciona a geração de óleo à intrusão de soleiras Cretáceas da Fm. Serra Geral nos folhelhos negros Irati Permianos; migração por falhas e paredes de diques e acumulação nos arenitos Triássicos Pirambóia. Fácies de interduna e fluviais da Formação Pirambóia agiram como armadilhas horizontais enquanto os diques básicos agiram como armadilhas verticais. Os diques e soleiras relacionados às ocorrências foram datados utilizando o método ${ }^{40} \mathrm{Ar} /{ }^{39} \mathrm{Ar}$ que forneceu uma idade de $134 \pm 2 \mathrm{Ma}$. Além disso, processos denudacionais iniciados no Cretáceo Superior erodiram as acumulações expondo-as.

Elementos estratigráficos e estruturais são relacionados à gênese dos arenitos asfálticos. Entretanto, os elementos estruturais derivados da Reativação Pós-Paleozóica foram considerados como os principais responsáveis pela geração, migração e acumulação. 


\section{Abstract}

Tar sandstones occurring in the eastern border of the Paraná Basin, state of Sao Paulo (SP), were studied in order to develop a genetic model. These occurrences have been studied since the $19^{\text {th }}$ century, however a model has not yet been proposed for their genesis. This work presents a genetic model based on an integrated spatial analysis of a database composed of morphostructural, digital elevation model (DEM), field work, geochronologic dating, airborne and land magnetometrics, remote sensing and gravimetric data.

As a result it was concluded that the best model relates oil generation to the intrusion of Cretaceous sills of the Serra Geral Formation into the Permian black shales of the Irati Formation; migration along faults and dyke walls and accumulation in Triassic sandstones of the Pirambóia Formation. Interdune and fluvial facies of the Piramboia Formation acted as horizontal traps, whereas the basic dykes acted as vertical traps. The basic dykes and sills associated with these occurrences were dated using the ${ }^{40} \mathrm{Ar} /{ }^{39} \mathrm{Ar}$ method, which gave an age of $134 \pm 2 \mathrm{Ma}$. Denudation processes beginning in the Late Cretaceous have exposed the tar sandstones.

Stratigraphic and structural elements were fundamental to the genesis of tar sandstones. The structural elements related to the Post-Paleozoic Reactivation were mainly responsible for hydrocarbon generation, migration and accumulation. 


\section{CAPÍTULO 1}

\section{INTRODUÇÃO}

Os arenitos asfálticos são compostos por grãos siliciclásticos ou carbonáticos impregnados, nos poros, por um óleo cru pesado, semelhante ao asfalto, chamado betume. $O$ betume é demasiadamente viscoso para ser recuperado por técnicas convencionais de extração de petróleo. Em média, os arenitos asfálticos contêm de 10-15\% de betume e o restante é composto de arenito ou outros materiais inorgânicos (OSSRN, 2003).

$\mathrm{Na}$ Bacia do Paraná, existem diversas ocorrências de hidrocarbonètos, as quais foram descritas principaimente a partir de afloramentos e sondagens. A borda leste da Bacia do Paraná no Estado de São Paulo é rica em afloramentos de arenitos asfálticos ou betuminosos. Estas ocorrências são compostas principalmente por arenitos da Formação Pirambóia, principalmente de granulometria média e de boa permeabilidade/porosidade, os quais foram preenchidos secundariamente por hidrocarbonetos. A maior parte dos afloramentos não contém óleo no estado líquido.

Historicamente, a área de estudo tem grande importância como marco do início da pesquisa de petróleo no Brasil. Em 1890 o cientista belga Auguste Collon foi contratado pelo fazendeiro Ferreira Camargo. A partir do trabalho de Collon foi perfurado o primeiro poço exploratório, na Bacia do Paraná, junto ao Morro do Bofete, próximo a uma ocorrência de arenito asfáltico.

As ocorrências de arenitos asfálticos no Estado de São Paulo foram alvo de intenso estudo durante a primeira metade do século passado. Após a primeira guerra mundial, houve a percepção no país da necessidade de se procurar reservas próprias de hidrocarbonetos. Nesta época foram instaladas duas minerações de arenito asfáltico visando obtenção de um produto para pavimentação à frio e também para destilação de petróleo. Na segunda metade do século, a Petrobrás pesquisou a região visando acumulações de óleo e gás em armadilhas estruturais. A partir do final dos anos 70 e início dos anos 80 , a Paulipetro também pesquisou a região executando levantamentos geológicos e geofísicos.

A gênese das ocorrências de arenito asfáltico encontradas na área está relacionada aos sistema petrolífero Irati-Pirambóia (Araújo et al., 2000). A rocha geradora é composta pelos folhelhos negros da Fm. Assistência, Subgrupo Irati (Hachiro et al., 1993). As rochas reservatório são compostas por arenitos da Fm. Tatuí e Fm. Pirambóia.

Este trabalho apresenta inicialmente a distribuição espacial das principais ocorrências de arenitos asfálticos no Estado de São Paulo e discute seus aspectos descritivos. Foram realizados levantamentos geológicos e geofísicos em escalas regionais e em semi-detalhe. 
Os aspectos descritivos das ocorrências apresentados inicialmente são analisados espacialmente com os dados de levantamentos geológicos e geofísicos. Finalmente, apresentam-se questões relacionadas à gênese dos arenitos asfálticos e hipóteses de trabalho plausíveis, segundo os dados disponíveis.

O trabalho envolveu, além de visita e catalogação das ocorrências da área, processamento digital de imagens de sensoriamento remoto e processamento de dados aeromagnetométricos, gravimétricos e magnetométricos. Foi realizada a interpretação de lineamentos e feições magnéticas, de relevo e drenagem.

Dados de campo demonstram que o magmatismo Serra Geral relaciona-se às ocorrência nos processos de geração e migração primária e secundária. Procura-se estabelecer neste trabalho a cronologia dos eventos relacionados aos processos de migração e acumulação. Datações geocronológicas $\mathrm{K} / \mathrm{Ar}$ e ${ }^{40} \mathrm{Ar} /{ }^{39} \mathrm{Ar}$ foram realizadas em rochas básicas da Fm. Serra Geral relacionadas às ocorrências. Não é descartada a importância de eventos Permianos ligados à Orogenia La Ventana nos processos de migração. Este evento propiciaria a formação de estruturas que afetaram desde os sedimentos permianos até o embasamento e que foram posteriormente reativadas durante os eventos tectonomagmáticos no Juro-Cretáceo. Deste modo, estas estruturas condicionariam tendências estruturais e caminhos de migração.

O objetivo principal do estudo é a proposição de um modelo genético a partir da análise das relações espaciais das ocorrências com as interpretações de dados aeromagnetométricos, gravimétricos, dados de sensoriamento remoto e de campo. Neste trabalho são apresentados e discutidos modelos para a ocorrência de arenitos asfálticos na região.

\subsection{Importância dos arenitos asfálticos (econômica e científica)}

$\mathrm{O}$ arenito asfáltico também chamado de arenito betuminoso e em inglês de oil sands, tar sands, asphaltic sandstones, heavy-oil deposits ou bitumen-impregnated sandstones, ocorre em diversas regiões do mundo. $O$ tamanho das reservas mundiais não está bem definido (Tabela 1); os recursos recuperáveis variam de 354 à 670 bilhões de barris de betume (OSSRN, 2003). Entretanto, há fontes que indicam reservas no Canadá da ordem de 1,6 trilhão até 2,5 trilhões de barris de betume e na Venezuela da ordem de 1,2 trilhão de barris (O Estado de São Paulo, Domingo, 17 de agosto de 2003). Grandes reservas também são encontradas na Rússia. As principais acumulações canadenses ocorrem na província de Alberta na região oeste daquele país, próximas ao Rio Athabasca. Estas ocorrências são as maiores do mundo em arenito asfáltico e também como hidrocarboneto. As reservas de Alberta são da ordem de 260 bilhões de barris e podem conter cerca de 1/3 das reservas mundiais de arenito asfáltico (OSSRN, 2003; Tabela 1). Estas acumulações têm volumes 
expressivos a ponto de serem consideradas como uma fonte alternativa às grandes acumulações do Oriente Médio. Entretanto, existem problemas de ordem econômica, relativos ao custo de produção, e questões de ordem ambiental, associados à sua lavra e disposição de rejeitos, bem como o problema associado à emissão de gases provocadores do efeito estufa derivado da extração e refino do óleo pesado.

Também existem ocorrências menores nos estados norte americanos de Utah e Kentucky ( 3 bilhões de barris; Noger, 1999). Pequenas ocorrências localizam-se nos estados do Alabama, Califórnia, Novo México; Ohio, Texas, Wyoming e Montana. Outras ocorrências também são descritas em Trinidad \& Tobago. Além disso, há depósitos na Nigéria com volume de 30 bilhões de barris (The Guardian, quarta-feira, 2 de Abril de 2003).

Geologicamente estas ocorrências não podem ser explicadas por um único controle geológico. Em comum, a maioria das ocorrências, no mundo, têm a localização próxima da borda da bacia sedimentar, este controle demonstra a área de exumação do pacote sedimentar mas também pode indicar fluxós hidrodinâmicos para fora da bacia em função da compactação dos pacotes sedimentares ao longo do tempo geológico.

A localização das ocorrências conhecidas no Estado de São Paulo também não podem ser explicadas por um único controle geológico. Os trabalhos de pesquisa superficial indicam que a proximidade dos depósitos em relação a lineamentos, falhamentos e altos estruturais sugerem controle e orientação estruturais. $O$ posicionamento estratigráfico exclusivamente em arenitos da base da Fm. Pirambóia indica a possibilidade de armadilhas estratigráficas ou posicionamento em zonas porosas localizadas. $O$ detalhamento através de estudos geofísicos potenciais indica a relação direta com diques de rochas básicas. Há consenso em relação à origem dos hidrocarbonetos que provêm dos folhelhos negros da Fm. Assistência do Subgrupo Irati (subdivisão proposta por Hachiro et al. 1993).

Tabela 1: Recursos recuperáveis de arenito asfáltico no mundo. Campbell (1997 apud OSRRN, 2003).

\begin{tabular}{|l|c|}
\hline \multicolumn{2}{|c|}{ Recursos de arenito asfáltico recuperáveis no mundo* } \\
\hline \multicolumn{1}{|c|}{ Regiăo } & Recursos recuperáveis \\
\hline Estados Unidos & 4,3 \\
\hline Canadá & 265,5 \\
\hline América do Sul & 0,9 \\
\hline Europa Ocidental & 0,0 \\
\hline Europa Oriental & 0,1 \\
\hline Rússia & 76,2 \\
\hline Transcaucásia e Ásia Central & 2,0 \\
\hline África & 4 \\
\hline Ásia & 0,0 \\
\hline China & 1 \\
\hline Total mundial & 354,0 \\
\hline "Em bilhöes de barris assumindo um fator de recuperação de 10\%; dados adaptados do USGs, Oil \& Gas Journal \\
e AAPG.
\end{tabular}




\subsection{Objetivos}

A pesquisa tem como objetivo geral o estudo das ocorrências de arenitos asfálticos, de uma área na borda da Bacia do Paraná, para entendimento de sua gênese, a partir de análise estrutural/morfoestrutural e de dados geofísicos. Pretende-se compreender a relação das ocorrências de arenitos asfálticos conhecidas com a tectônica formadora/deformadora da bacia.

A cronologia dos processos de geração, migração e acumulação tem estreita relação com eventos tectônicos da Bacia, assim como com o magmatismo Serra Geral. Desse modo, estuda-se 0 arcabouço estrutural da área das ocorrências e realizam-se datações geocronológicas absolutas das rochas básicas na área.

A partir da realização dos trabalhos de campo, análise dos dados bibliográficos e dos dados levantados, algumas características dos arenitos asfálticos podem ser consideradas como pontos-chave para o entendimento de sua gênese. Estes pontos chave são apresentados a seguir como questões a serem respondidas e cujas respostas compõem as hipóteses de trabalho:

- As ocorrências são caracterizadas como reservatórios exumados ou exsudações (oil seeps)?

- Qual o papel do magmatismo Serra Geral na gênese das ocorrências?

- Quais elementos geológicos compõem o processo de migração?

- Como explicar o posicionamento estratigráfico das ocorrências?

- Como são caracterizadas as armadilhas nas ocorrências?

- Qual é a cronologia dos eventos que compõem o modelo de geração, migração e acumulação?

- Qual é o modelo geral para gênese de arenitos asfálticos? Há apenas um modelo?

- Todas as ocorrências foram geradas segundo o mesmo modelo?

\subsection{Justificativas}

O estudo da gênese das ocorrências de arenitos asfálticos auxilia o entendimento dos fatores envolvidos nos processos de migração de hidrocarbonetos na Bacia do Paraná. $O$ estudo de fatores relacionados à migração, como estratigrafia, arcabouço estrutural $e$ aspectos temporais, auxilia a caracterização do sistema petrolífero Irati-Pirambóia.

Apesar das ocorrências de arenitos asfálticos em São Paulo serem conhecidas há mais de um século, não há um modelo genético que as caracterize. Os trabalhos mais importantes acerca do tema (Franzinelli, 1972 e Thomaz Filho, 1982) levantam hipóteses com base em dados de afloramento. Há falta de modelos que considerem a história evolutiva da 
Bacia do Paraná durante o período de gênese das ocorrências, ou seja, que utilizem ferramentas de estudo do arcabouço estrutural e estratigráfico da bacia.

Além disso, o estudo de afloramentos na borda da bacia auxilia a prospecção nas porções mais profundas. Apesar do desenvolvimento tecnológico na aquisição de dados sísmicos propiciar imágeamento de alta qualidade, a utilização de analogias entre a geologia de áreas da borda com porções profundas da bacia ainda se faz muito útil. A utilização de dados geofísicos potenciais é outra ferramenta que pode ser empregada com excelentes resultados, especialmente quando interpretada com base em dados de superfície correlacionáveis à geologia não aflorante. Posteriormente, estes dados podem ser interpretados para as porções mais profundas da bacia com base nos princípios desenvolvidos na área de afloramento dos arenitos asfálticos a custos relativamente baixos.

\subsection{Localização da área de estudo}

A área de estudo localiza-se na região centro leste do Estado de São Paulo. Na porção norte da área estão as cidades de Botucatu. Anhembi e Conchas; na porção sul encontram-se Bofete, Guareí, Angatuba, Torre de Pedra e Porangaba. A área está completamente inserida na Bacia do Paraná, em sua borda leste.

O acesso à área (Figura 1.1) pode ser feito, a partir da cidade de São Paulo, através da rodovia Castelo Branco (SP-280), cidades de Bofete e Botucatu, também pode-se utilizar a rodovia Raposo Tavares (SP-270) para se chegar ao sul da área, cidades de Angatuba e Guareí. 


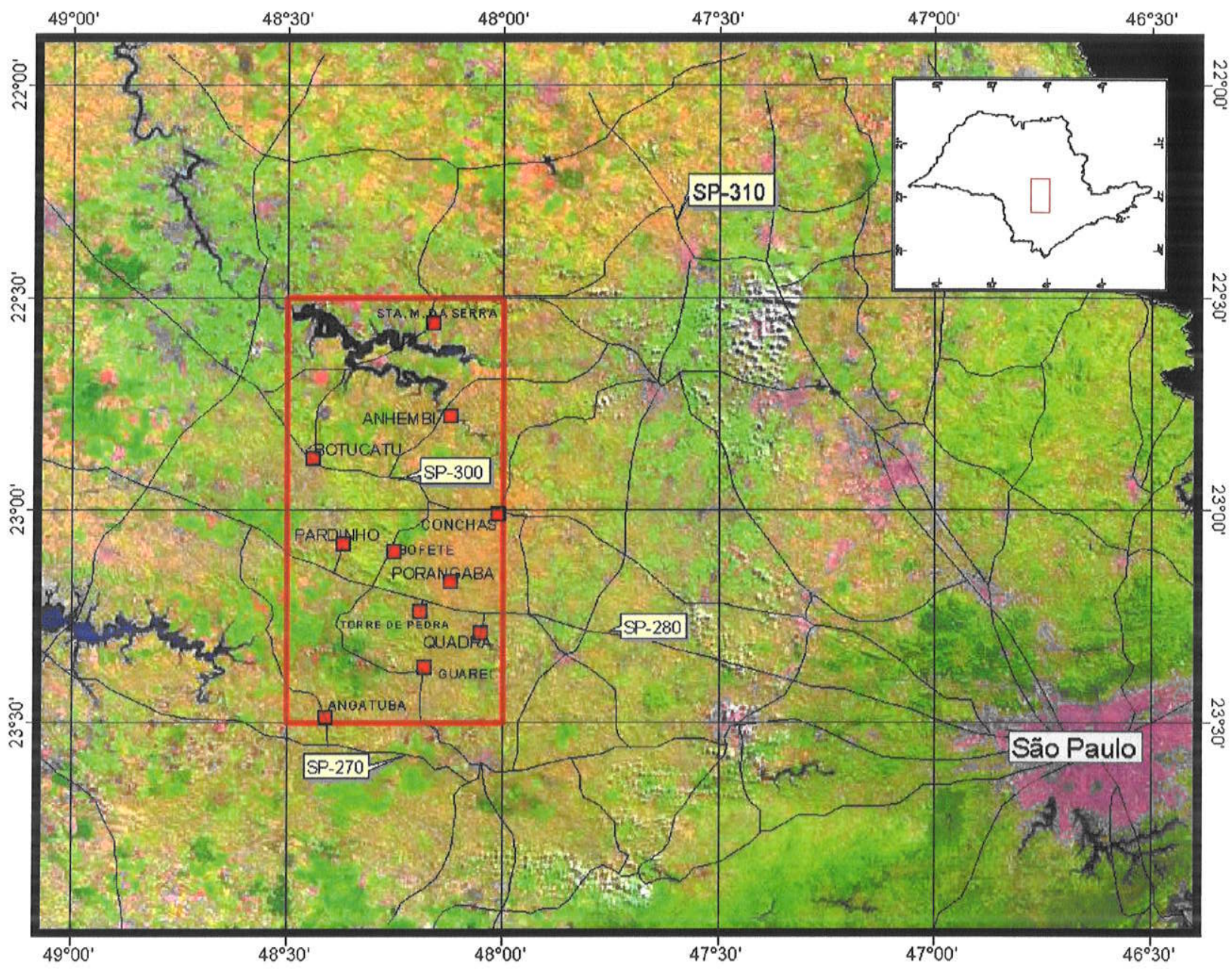

Figura 1.1: Localização da área de estudo. 


\section{CAPÍTULO 2}

\section{DADOS ANTERIORES}

Na região do Morro do Bofete, porção centro-sul da área de estudo, foi perfurado o primeiro poço de petróleo no Brasil (Souza, 1997). Era o ano de 1892 e o poço teve uma profundidade de $488 \mathrm{~m}$ donde extraiu-se 2 barris de óleo. A área de ocorrência dos arenitos asfálticos é estudada há décadas, há uma extensa bibliografia sobre o assunto. Neste capítulo são apresentados os principais trabalhos.

\subsection{Trabalhos anteriores}

A presença de arenitos asfálticos na borda leste da Bacia do Paraná é conhecida há várias décadas. Existem trabalhos clássicos desenvolvidos na região como os de Collon (1897), Oliveira (1920, 1940), Washburne (1930) e Franzinelli (1972).

O primeiro estudo da ocorrência de arenito asfáltico foi apresentado pelo belga Auguste Collon em 1897 numa área no Morro do Bofete. Neste primeiro trabalho, Collon (1897) atribui o betume do arenito à proveniência de um reservatório de petróleo rupturado em profundidade. Oliveira (1920) fez uma das primeiras descrições de afloramentos de arenitos asfálticos no interior do Estado de São Paulo. Segundo o autor, estas ocorrências acham-se sempre nas proximidades de diques de rochas eruptivas.

Segundo Washburne (1930), o arenito Botucatu incluindo o Pirambóia está situado na melhor posição para juntar todo o óleo que possa originar-se no folhelho Irati. $O$ autor faz referência a alguns indícios superficiais de petróleo. O maior deles é uma camada de arenito formando paredões ao sul do Rio Tietê na Fazenda Saltinho, próximo a Porto Martins.

Oliveira (1940) também cita diversos afloramentos de arenitos asfálticos em São Paulo. O autor teoriza que cada um desses afioramentos era um "lençol" de petróleo, a erosão carregou os sedimentos que protegiam essas jazidas, facilitando as ações das intempéries que sobre eles atuaram, polimerizando o petróleo e transformando-o em óleo pesado ou em produtos asfálticos.

O relatório do Conselho Nacional do Petróleo (CNP, 1944) evidencia a constância de arenitos betuminosos entre Guareí e as margens do Tietê, balizando sensivelmente linhas paralelas sul-norte. Para os autores do relatório (CNP, 1944), este "alinhamento" faz supor que esses depósitos são "jazidas fósseis" de óleo, postas a descoberto pela erosão.

Segundo Andrade \& Soares (1971), as principais ocorrências de hidrocarbonetos na borda leste da Bacia do Paraná encontram-se impregnando arenitos da Formação Pirambóia, 
ao sul do paralelo $22^{\circ} 15^{\prime} 00^{\prime \prime}$. Para os autores, devido à localização geográfica das jazidas e sua posição na coluna geológica, trata-se de óleo gerado no Subgrupo Irati porque somente a sul do referido paralelo, onde elas existem, ocorre toda a seção do Irati, que comprovadamente constitui a principal rocha geradora da área. Ainda que pouco definidas, para os autores, as observações de campo mostram a existência de um certo controle estrutural destas ocorrências de óleo. Segundo os autores, nenhuma evidência de óleo em superfície foi observada nas formações abaixo do Subgrupo Irati. Contudo, os poços perfurados na região de São Pedro e Bofete revelaram indícios de óleo e gás abaixo da referida formação.

Franzinelli (1972) descreve os arenitos Pirambóia como os acumuladores de hidrocarbonetos. Segundo a autora, o asfalto proviria do betume do calcário de sedimentos do Subgrupo Irati. Desse modo, ela considera a migração primária como responsável pela colocação do betume nos calcários. A autora observa que os arenitos asfálticos têm ocorrência em flancos de altos estruturais. A migração do betume do Subgrupo Irati até os arenitos teria ocorrido, segundo a autora, devido à formação de capilaridade e/ou devido à pressão gerada pelas intrusivas básicas. Falhamentos e fraturamentos teriam facilitado a migração do óleo.

Thomaz Filho (1982) estudou a ocorrência de arenito betuminoso em Anhembi (SP). Foram realizadas 26 sondagens, testemunhadas e perfiladas. As impregnações têm teores que variam desde indícios até valores ao redor de $17 \%$ de óleo em peso, com média de $5,5 \%$. A área de ocorrência do óleo atinge aproximadamente $0,4 \mathrm{~km}^{2}$ e a espessura de arenito impregnado chega a atingir valores superiores a $80 \mathrm{~m}$. Segundo o autor, comparandose a distribuição do arenito impregnado, com o mapa de contorno estrutural da base da Formação Pirambóia, observa-se que, além do dique de diabásio (constitui barreira no sentido horizontal para a migração do óleo), o posicionamento da impregnação ao longo do dique foi condicionado ao alto definido pelo contorno estrutural da base da Formação Pirambóia. Fúlfaro et al. (1997) apresentam um resumo descritivo dos condicionantes geológicos relacionados às ocorrências de arenitos asfálticos.

\subsection{Geomorfologia da área de estudo}

De modo geral, a área de ocorrência de arenitos asfálticos é caracterizada pela presença de depressões circundantes a planaltos sedimentares. No contato entre depressão e planalto encontram-se relevos escarpados na forma de cuestas. Na área de estudo, a partir de um ponto na Depressão do Paranapanema é possível observar a espetacular frente da cuesta de Botucatu, que é uma visão do Planalto de Botucatu. Este planalto tem desnível de até 200 metros numa distância de algumas centenas de metros. O planalto Residual de Botucatu, segundo Ross \& Moroz (1997), corresponde ao reverso da Cuesta no interflúvio 
Tietê/Paranapanema. As ocorrências encontram-se preferencialmente nas áreas de depressão, seja na região do Médio Tietê ou na região do Vale do Paranapanema.

Toda a área de estudo está na unidade Morfoestrutural da Bacia Sedimentar do Paraná (Ross \& Moroz, 1997). 'Esta unidade está dividida em unidades morfoesculturais, que na área são o Planalto Ocidental Paulista e a Depressão Periférica Paulista (Figura 2.1A). Na Figura 2.1B está o modelo numérico de terreno com a localização das principais ocorrências de arenitos asfáltico. Das unidades do Planalto Ocidental destacam-se: o Planalto Centro Ocidental e o Planalto Residual de Botucatu. Das unidades da Depressão periférica destacam-se: a depressão do Médio Tietê e a depressão do Paranapanema.

A região é caracterizada pela presença de colinas amplas e baixas com topos convexos e topos aplanados ou tabulares.

As áreas da depressão do Paranapanema e Médio Tietê, onde ocorre o arenito asfáltico, apresentam padrões de drenagem paralelos e também dendríticos, freqüentemente com alinhamentos de drenagem de direções NE e NW relacionados diretamente ao padrão de fraturamento da Bacia do Paraná. Nas áreas de ocorrência de arenito asfáltico as formas de relevo são de colinas de topos convexos e tabulares. Localmente, observam-se as ocorrências em fundo de vales e em encostas. Não foram observadas ocorrências em topos de morros. 
A

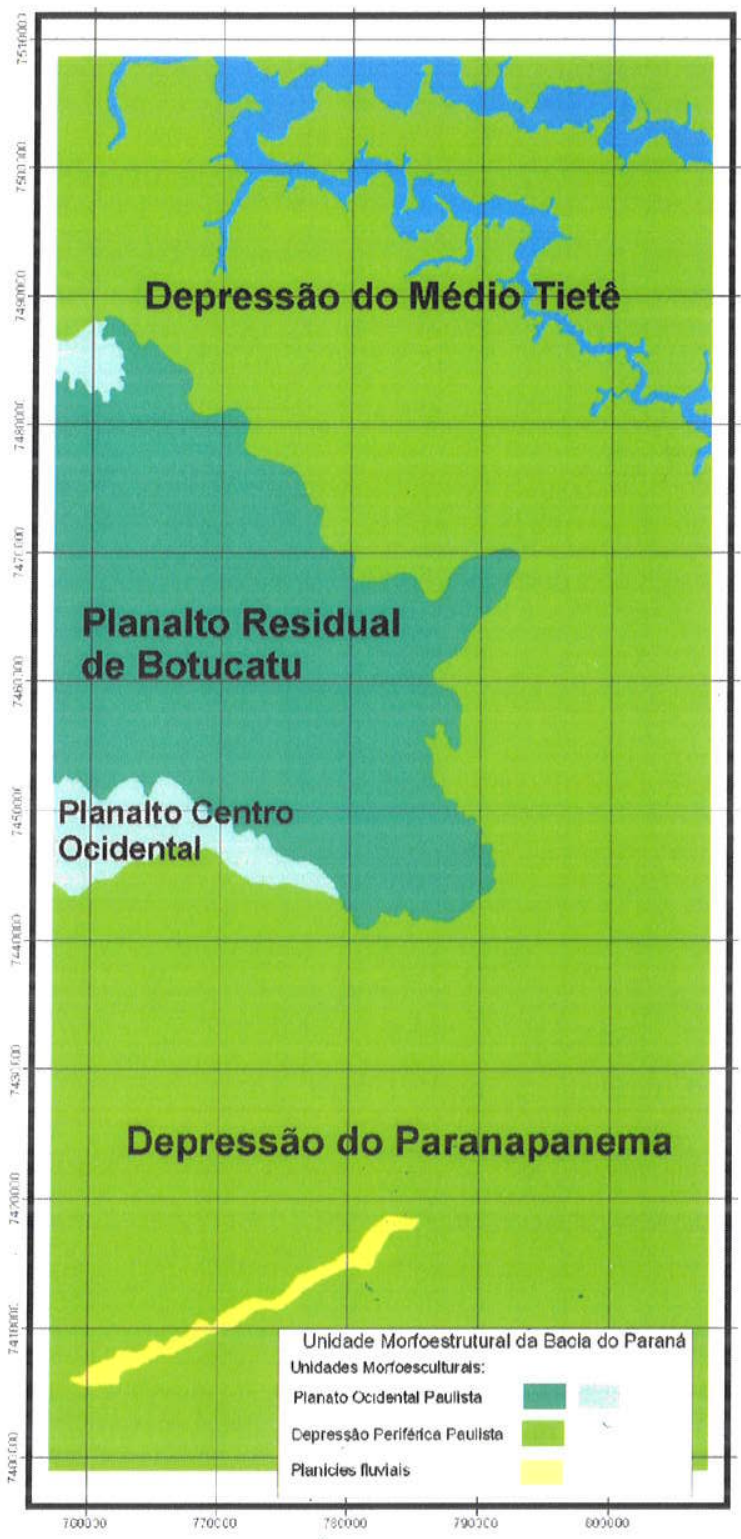

B

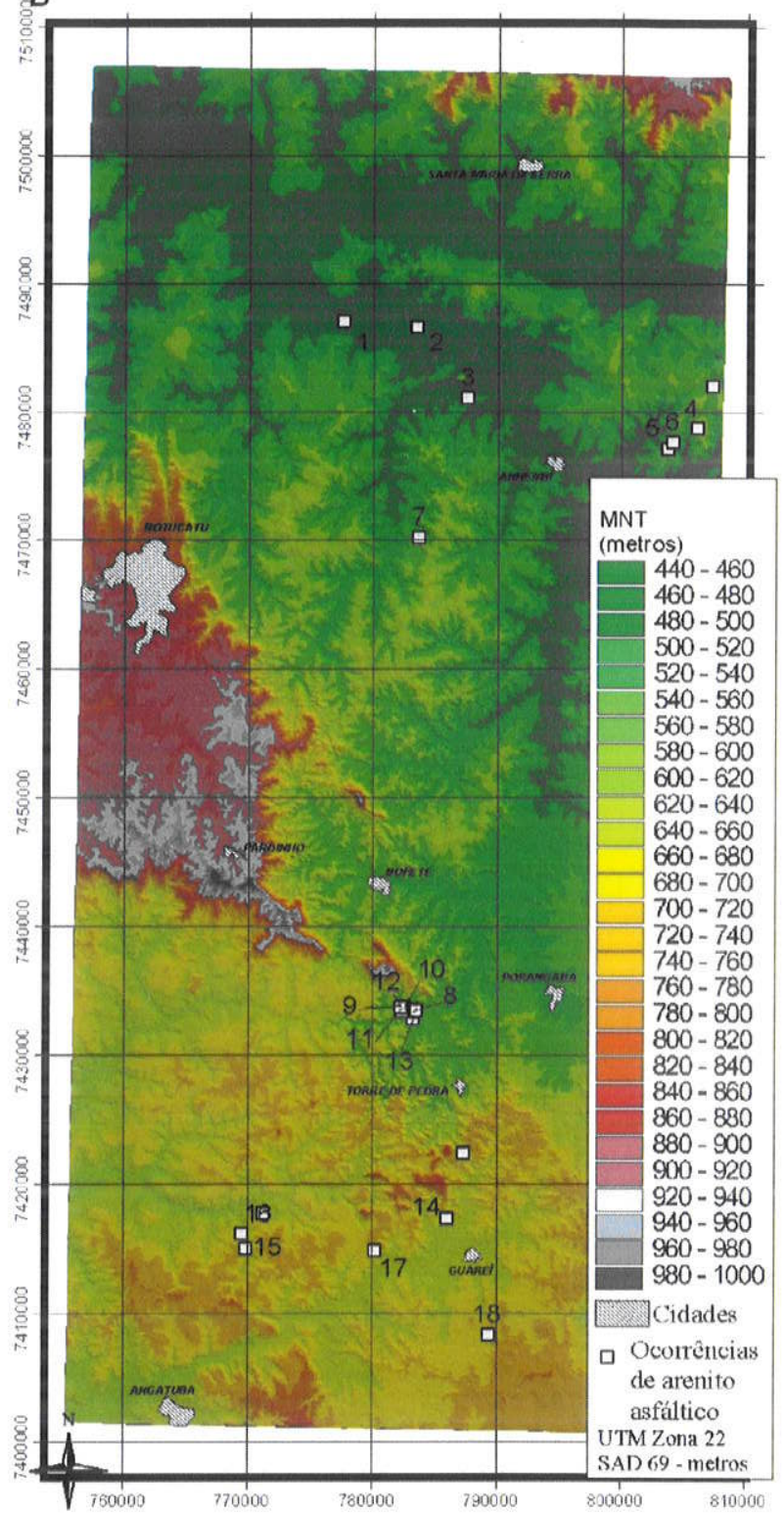

Figura 2.1: (A) Contexto geomorfológico e (B) modelo numérico de terreno (MNT). Ocorrências: 1 Porto Martins; 2 - Volta Grande; 3 - Braço da Represa; 4 - Betumita; 5 - Moquém I; 6 - Moquém II; 7 - Piapara; 8 - Morro do Bofete; 9 - Fazenda São Jorge; 10 - Estrada da Mina; 11 - Bairro da Mina; 12 - Bairro da Mina II; 13 - Estrada da Mina II; 14 - Nhaíva; 15 - Sobar; 16 - Sobar II; 17 - Itatigue; 18 Jacutinga.

Vários autores citam os processos erosionais instalados na Bacia do Paraná e regiões circunvizinhas e relacionam superfícies de aplainamento ao longo do tempo geológico (King, 1956, Almeida, 1964; Ab'Saber, 1969). Sem dúvida, estes processos erosionais iniciados no final do Cretáceo e posteriores desnudaram as coberturas geológicas que encobriam as acumulações de hidrocarbonetos da Fm. Pirambóia.

Para King (1956), a discordância do Cretáceo em relação às lavas triássicas (Fm. Serra Geral, Cretáceo) ao arenito Botucatu e às formações permianas e carboníferas, representa a superfície Gondwana, que é posteriormente modificada por um ciclo post- 
Gondwânico, representado pela superfície Pós-Gondwana. Segundo o autor, esta superfície forma uma zona de terrenos acidentados entre um remanescente da superfície Gondwana e a superfície Sul-Americana. Finalmente, segundo King (1956), a superfície Sul Americana foi esculpida durante um longo período no decorrer do Terciário inferior e atingiu grande uniformidade e aplainamento. Ainda segundo esse autor, esta superfície constitui um planalto dissecado e recobre a maior parte do oriente paulista. Vários autores têm atribuído à superfície Sul-Americana idades que vão desde o Eoceno ao Plioceno. King (1956) admite idades de aplainamento desta superfície no intervalo entre o fim do Cretáceo e o início do Mioceno.

Segundo Almeida (1964), há evidências da presença de uma antiga superfície de erosão senil que nivelou e esculpiu estruturas pré-cambrianas no Estado de São Paulo. Em relação a esta antiga superfície, Ab'Saber (1954 apud Almeida, 1964) afirma que há simultaneidade entre a sedimentação cretácea da Bacia do Paraná e processos de pediplanação, dos quais resultaria a superfície chamada de Japi. Segundo IPT (1981), a superfície do Japi é uma das mais extensas superfícies de aplainamento do sul do Brasil. Segundo Almeida (1964), pode se ter certeza que a superfície do Japi é anterior à sedimentação Pliocênica das bacias do Paraíba e São Paulo.

\subsection{Contexto geológico}

$\mathrm{Na}$ área de estudo, afloram as rochas do Subgrupo Irati e da Formação Teresina, Permiano e Grupo São Bento, Triássico-Jurássico assinalados na Figura 2.2. Na base da seqüência aflorante, estão as rochas do Subgrupo Irati compostas por seqüências de folhelhos e calcários. Em seguida, encontram-se os litotipos da Formação Serra Alta (na base) e Formação Teresina (no topo), compostos basicamente por siltitos arroxeados intensamente fraturados, apresentando-se "empastilhados" nos afloramentos. No topo da Formação Teresina encontra-se a Camada Porangaba (Matos, 1995; Matos \& Coimbra, 1997), composta por brechas, ora de matriz pelítica, ora de matriz arenosa com intraclastos. 


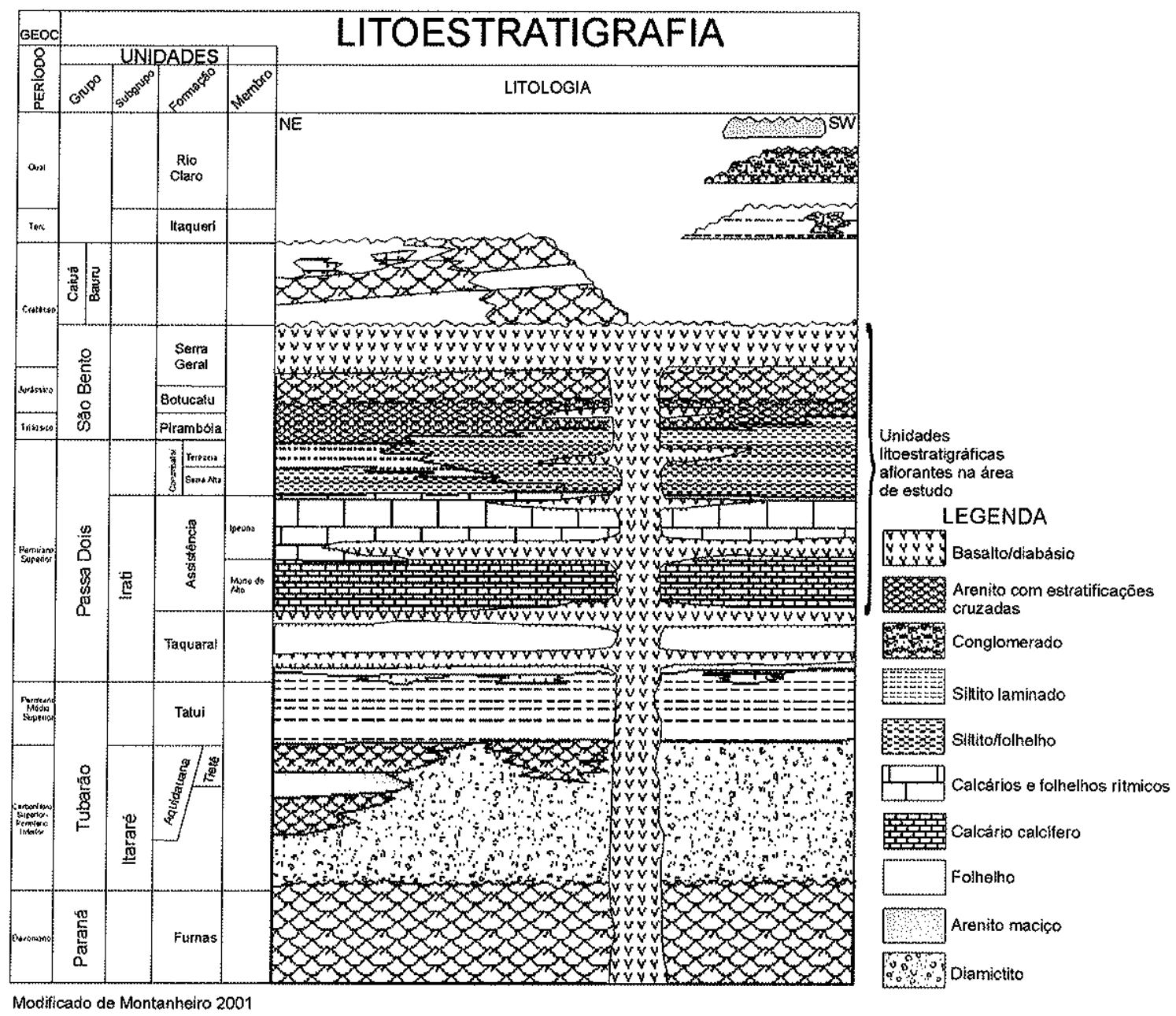

Figura 2.2: Litoestratigrafia da área de estudo.

O Grupo São Bento na área de estudo é constituído pelas Formações Pirambóia, Botucatu e Serra Geral. Em contato, ora abrupto, ora transicional com a camada Porangaba encontram-se os arenitos da Formação Pirambóia, constituídos por arenitos médios e finos em seqüências de estratificações cruzadas métricas de grande porte. Por vezes, verificam-se estratificações plano-paralelas nos arenitos da Formação Pirambóia próximos ao contato com a Camada Porangaba. Também foram observados litotipos compostos por siltitos e argilitos, de forma lenticular intercalados nas seqüências de estratificações cruzadas, provavelmente relacionados a depósitos de interdunas. A Formação Botucatu contém arenitos avermelhados com grãos foscos bem arredondados médios. Esta litologia, na área de estudo, tem um aspecto monótono com estratificações cruzadas, de grande porte, tangenciais na base. $\mathrm{Na}$ área afloram rochas básicas da Formação Serra Geral na forma de derrames tabulares sobrepostos à Formação Botucatu e também na forma de soleiras na Formação Pirambóia e no contato Teresina/Pirambóia, além de numerosos diques dispersos por toda a região.

As principais estruturas presentes na área são os altos estruturais de Anhembi e Carlota Prenz, além do sistema de falhas Torre de Pedra e Morro do Bofete. Estas estruturas 
caracterizam-se pelo afloramento de rochas da Formação Teresina (Permiano) contornadas por rochas da Formação Pirambóia (Triássico). Mais de $90 \%$ das ocorrências estudadas estão espacialmente próximas destas estruturas.

Junto à represa de Barra Bonita, às margens do Rio Tietê, cercanias da cidade de Anhembi, tem-se o Alto Estrutural de Anhembi (Soares, 1974). As cotas topográficas na área variam de 450 a $600 \mathrm{~m}$ e os contatos entre a Formação Pirambóia e Teresina variam de 460 até $545 \mathrm{~m}$, de acordo com levantamentos de campo. A estrutura de Anhembi caracteriza-se por um eixo maior de direção N50W e falhas de direção N, NW e NE, as quais separam os arenitos da Formação Pirambóia dos siltitos roxos da Formação Teresina. Esta estrutura pode ser compartimentada em três blocos (Petrobrás 1971, apud Franzinelli 1972) chamados Alto de Anhembi, na porção norte da estrutura, Alto de Anhembi Sul, na porção intermediária e Alto de Piapara, na porção sudoeste.

O alto estrutural de Carlota Prenz (Still 1952, apud Soares 1974) aflora na porção sul da área de estudo, ao norte da cidade de Angatuba. Nesta estrutura afloram rochas sedimentares da Formação Teresina circundadas pelos arenitos da Formação Pirambóia. Os siltitos Teresina afloram em dois corpos quilométricos de forma elíptica, cujo eixo maior tem direção aproximada N-S. O alto estrutural de Carlota Prenz ocorre dentro de uma estrutura anelar, aqui denominada Estrutura de Jacu. Esta estrutura caracteriza-se por uma forte anomalia de drenagem anelar (rios Santo Inácio e Capivari) e drenagens radiais concêntricas presentes na porção sul da estrutura (Ribeirão Antônio José e Ribeirão da Restinga). $O$ alto estrutural de Carlota Prenz localiza-se junto a estas drenagens radiais. Em toda a extensão desta estrutura anelar afloram arenitos da Formação Pirambóia, à exceção da área do Domo de Carlota Prenz onde afloram siltitos roxos da Formação Teresina.

O sistema da falhas Torre de Pedra tem direções que variam de N30E a N4OW, este sistema localiza-se no limite leste da estrutura anelar. Segundo Soares (1973) e Franzinelli (1972), uma falha normal deste sistema aflora na Rodovia Castelo Branco, km 183 próximo à ocorrência de arenito asfáltico do Morro do Bofete. O sistema Guareí tem direção N40E e localiza-se na porção SE da estrutura anelar e o sistema Morro do Bofete de direção N50W está no limite N-NE da estrutura.

\subsection{Bacia do Paraná - sedimentação, estratigrafia e tectônica}

A Bacia do Paraná implantou-se no Cambro-Ordoviciano sobre um embasamento cratônico. Segundo Zalan et al. (1991), o início da bacia ocorreu por subsidência termal conforme se deu o resfriamento de grandes áreas quentes afetadas por metamorfismo, plutonismo e deformação durante o evento orogênico Brasiliano. Este embasamento cratônico tem uma estruturação NW com blocos limitados por falhas nesta mesma direção. Segundo Fúlfaro et al. (1982), a sedimentação no Devoniano e início do Permocarbonífero 
apresenta distribuição e maior espessura de sedimentos na direção NW-SE devido ao controle dos limites destas antigas estruturas.

Segundo Zalan et al. (1991), a evolução tectono-sedimentar da bacia consistiu, no Paleozóico, de deposição de três seqüências sedimentares trangressivo-regressivas (Siluriano, Devoniano e Permo-Carbonífero). Durante o Mesozóico, a bacia desenvolveu-se via deposição de duas seqüências sedimentares principais (Triássico, Juro-Cretáceo). A deposição destas seqüências foi influenciada pelo clima, por anomalias termais e por tensões relacionadas com o manto derivadas da ruptura entre a América da Sul e a África. Segundo os autores, estas seqüências são separadas por inconformidades e foram depositados durante as três principais fases de subsidência (Siluriano-Devoniano, Carbonifero Superior-Permiano, Jurássico Superior-Cretáceo Inferior), cada uma sendo interpretada como representando bacias diferentes em tempo e espaço.

Fúlfaro et al. (1982) descrevem, para a transição permo-triássica, uma mudança do nível de base regional. Neste período, um mar raso (Teresina/Corumbataí) é ocupado por dunas litorâneas (Pirambóia) e posteriormente por dunas de um deserto continental (Botucatu). Para Fúlfaro et al. (1982), esta mudança ocorreu, em princípio devido ao levantamento dos Andes Meridionais e a movimentação tectônica positiva do assoalho da Bacia do Paraná.

Riccomini (1995) descreve diques clásticos presentes em litotipos da Formação Teresina como evidências diretas do tectonismo sinsedimentar no Permiano Superior da Bacia do Paraná. O autor considera estas feições como resultantes de abalos sísmicos durante estágios precursores da ruptura continental; estudos posteriores estenderam esta interpretação para deformações presentes em depósitos arenosos da Formação Pirambóia e Formação Rio do Rasto. Riccomini (1995) conclui, após a análise da orientação preferencial dos diques, que houve uma direção de extensão segundo NW-SE, compativel com os primeiros esforços de ruptura do Gondwana, provavelmente relacionados à reativação de estruturas antigas do substrato da bacia. 


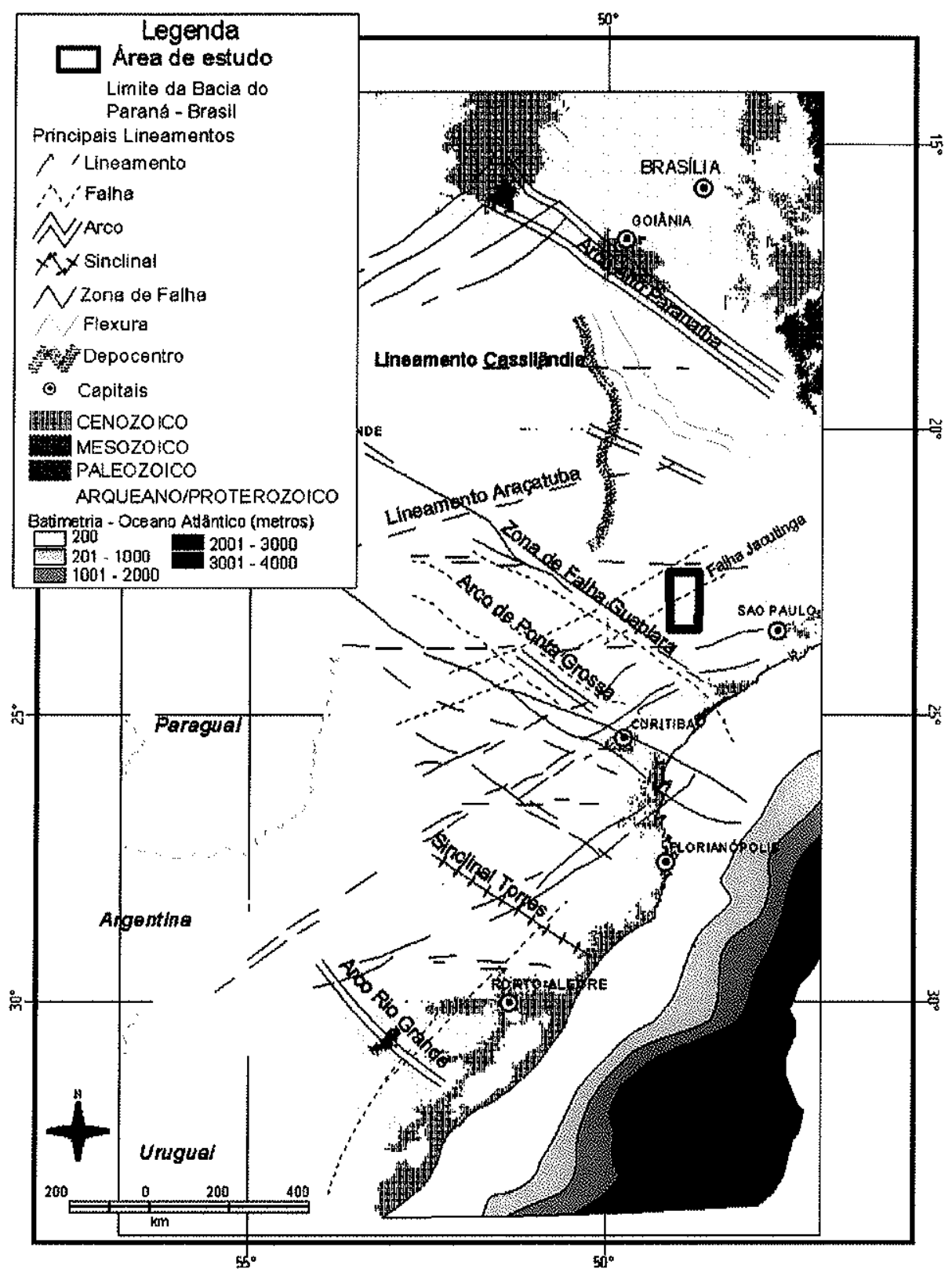

Figura 2.3: Elementos estruturais da Bacia do Paraná, Brasil (modificado de Zalan, 1991; CPRM, 2001a e b).

Segundo Fúlfaro et al. (1982), durante o Juro-Cretáceo, intenso vulcanismo afeta toda a Bacia do Paraná. Diques de rochas básicas alinhados NW desde o litoral sul de São Paulo até o interior dó Paraná constituem o Arco de Ponta Grossa. Ferreira (1982) admite a atuação tectônica do Arco de Ponta Grossa desde o Devoniano com a maior atividade no JuroCretáceo. Segundo Ferreira (1982), o Alinhamento de Guapiara, integrante do Arco de Ponta Grossa em sua porção NE, possui um comportamento heterogêneo relativamente às direções estruturais, polaridades e incidência de diques. Para o autor, o conjunto de fenômenos responsáveis pelo condicionamento tectônico dos diques deu-se em intervalos diferentes do tempo geológico. Segundo Ferreira (1982), a direção predominante dos diques da região 
central do Arco de Ponta Grossa é N50W, embora observe-se que ela varia desde N30W até E-W.

$\mathrm{Na}$ área de ocorrência dos arenitos asfálticos é notável a presença de estruturas lineares de duas direções principais: NW e NE. Estas estruturas são compostas por falhas, diques de rochas básicas e alinhamentos aeromagnéticos e de relevo. Considera-se que o padrão NW está ligado ao Arco de Ponta Grossa, principalmente às reativações ao longo do alinhamento Guapiara, ou seja, ao tectonismo derivado da Reativação Wealdeniana (Almeida, 1967), termo modificado para Evento Sul-Atlântico por Schobbenhaus et al. (1984). Adotou-se o termo Reativação Pós-Paleozóica (Almeida \& Carneiro, 1989) para os eventos tectono-magmáticos atuantes desde o Triássico e durante o Jurássico relacionados à origem do Oceano Atlântico e fragmentação do supercontinente Pangea. O padrão NE também sofreu influência dos fenômenos citados acima, mas considera-se sua origem principal nas zonas de fraqueza do embasamento. Em toda a Bacia do Paraná, segundo Zalan et al. (1991), dois estilos estruturais principais estão presentes: deformações associadas a intrusões ígneas e deformações associadas a reativações com elementos tectônicos lineares de direção NE e NW (Figura 2.3).

\subsection{Formação Pirambóia}

A Formação Pirambóia é composta por sedimentos siliciclásticos de idade Triássica. O aspecto geral é o de afloramentos com arenitos brancos, cinzas, amarelados e avermelhados, onde ocorrem estruturas sedimentares como estratificações cruzadas de médio e grande portes e estratificações plano-paralelas em depósitos de interdunas. Os arenitos têm granulometria média, os grãos são polidos, subangulares e subarredondados, mal selecionados, há porções siltosas e argilosas (Petri \& Fúlfaro, 1983). Na área de estudo, a formação atinge espessuras de até $130 \mathrm{~m}$ em poços na região de Anhembi.

O clima semi-árido durante a sedimentação é aceito pela maioria dos autores (Petri \& Fúlfaro 1983, Briguetti 1994, Caetano-Chang 1997). Em termos de fácies, a Fm. Pirambóia contém elementos que indicam presença de deposição eólica e aquosa na base da formação e domínio das condições de deposição eólica para o topo da formação. Entretanto, não há mapeamentos sistemáticos de fácies deposicionais da Fm. Pirambóia demonstrando seu comportamento espacial.

'Briguetti (1994) identificou quatro grupos de fácies na Formação Pirambóia: dunas, interdunas, lençóis de areia e fluviais. Próximo à base da formação, na proximidade com o contato da Formação Corumbataí, ocorrem depósitos tipicamente formados em regime eólico, caracteristicamente de dunas eólicas. Em toda a porção média e também em direção ao topo predominam depósitos de dunas e interdunas. Próximo ao contato com os sedimentos da 
Formação Botucatu, Briguetti (1994) observou depósitos de dunas eólicas com predomínio de granulometria fina e alto grau de foscagem nos grãos.

Caetano-Chang (1997), a partir de perfis de poços na região de Anhembi, descreve que as variações de fácies evidenciam, de modo geral, a diminuição da presença de água influenciando a sedimentação. Ou seja, na base dos perfis Caetano-Chang (1997) identificou predominância de fácies aquáticas inclusive fácies de interdunas. Em direção ao topo Caetano-Chang (1997) interpreta a deposição de extensos depósitos de areias eólicas em condições de maior aridez.

O contato basal da Formação Pirambóia com a Formação Teresina tem origem controversa. Segundo Petri \& Fúlfaro (1983), o início da deposição de Formação Pirambóia é marcado, em grande área do Estado de São Paulo, por regolito fóssil, sob forma de brecha de siltito em matriz arenosa. A partir de estudo de fácies, Matos (1995) reconhece a atuação de processos deposicionais regidos por marés no regolito fóssil, intercalando produtos de deposição de sedimentos finos e de exposição e constituindo uma sucessão de fácies com passagem transicional. $O$ autor propôs o estabelecimento de nova unidade litoestratigráfica denominada camada Porangaba, substituindo a denominação "regolito fóssil" e passando a integrar o topo do Grupo Passa Dois, o que caracteriza o contato transicional Teresina/Pirambóia. Em relação ao contato basal, Caetano-Chang (1997) comenta que as pseudo-brechas e brechas de intraclastos que antecedem a sedimentação Pirambóia fazem parte da história sedimentar do final da sedimentação Corumbataí/Teresina. Segundo a autora, os arenitos eólicos da Fm. Pirambóia localmente, assentam-se diretamente sobre os sedimentos finos subjacentes, indicando ação de erosão eólica mais pronunciada. Dessa forma, a autora afirma que os dados confirmam a existência de extensiva discordância préPirambóia na porção nordeste da Bacia.

\subsection{Magmatismo associado e geocronologia}

$\mathrm{Na}$ Bacia do Paraná foram realizadas diversas datações geocronológicas a partir de amostras das rochas vulcânicas. A Figura 2.4 apresenta as datações geocronológicas de rochas vulcânicas na Bacia do Paraná próximas à área de estudo.

Estas rochas foram datadas na região por Melfi et al. (1967) utilizando o método K-Ar em amostras de testemunhos de sondagens. Dentro da área de ocorrência dos arenitos asfálticos, a única datação disponível até o momento foi feita próximo à ocorrência Sobar, a partir de amostra de testemunho de sondagem do Poço CP-1-SP (Petrobrás). Na área de perfuração ocorre a estrutura dômica de Carlota Prenz. A idade de $128.4 \mathrm{Ma}$ foi obtida para amostra de rocha total de diabásio.

Os diques associados às ocorrências de arenito asfáltico são classificados como derivados do magmatismo Serra Geral. Entretanto, a idade Serra Geral não está claramente 
definida. Segundo Rocha-Campos et al. (1988), ao considerar o magmatismo em toda a Bacia do Paraná, conclui-se que há mais de um evento ígneo envolvido. Segundo os autores, é quase certo que pilhas completas de fluxos de lava de centenas de metros de altura podem ter sido extrudidas em um curto intervalo de tempo. Além disso, também é igualmente verdadeiro que regionalmente os eventos vulcânicos exibem claras variações de idade. Para Rocha-Campos et al. (1988), a fase principal da atividade vulcânica é indicada por resultados radiométricos K-Ar como Cretáceo Inferior (130-135Ma) e a duração do magmatismo (basaltos de derrames e vulcânicas associadas) tem um intervalo sugerido entre 160 e 100 Ma.

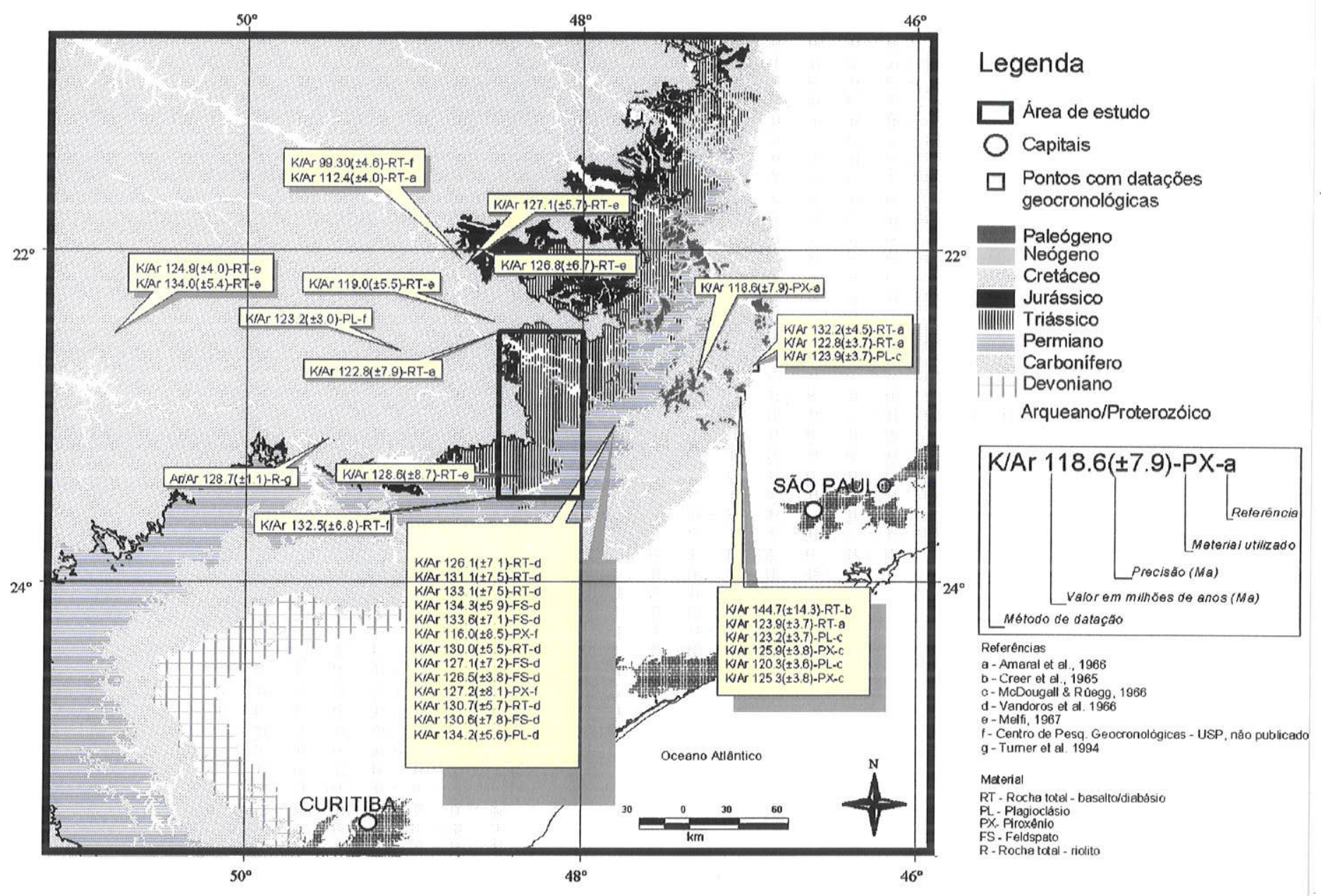

Figura 2.4: Sumário das datações geocronológicas disponíveis na região de estudo.

Renne et al. (1992) apresentam a idade do vulcanismo da Bacia do Paraná a partir de idades ${ }^{40} \mathrm{Ar}-{ }^{39} \mathrm{Ar}$ da ordem de $132.9 \pm 0.6 \mathrm{Ma}$ a $131.4 \pm 1.6 \mathrm{Ma}$. Para os autores o magmatismo de toda a província ocorreu em um intervalo aproximado de $1 \mathrm{Ma}$.

Turner et al. (1994) mostram resultados de datações que a bacia do Paraná teve erupções em um período de 10 Ma entre 137 e 127 Ma. Segundo os autores, as idades mais antigas de rochas vulcânicas são encontradas na porção norte e oeste da bacia, já as idades 
mais jovens estão concentradas no sul e leste sugerindo uma migração do magmatismo ao longo do tempo.

Stewart et al. (1996), utilizam dados geocronológicos ${ }^{40} \mathrm{Ar}-{ }^{39} \mathrm{Ar}$, complementam a amostragem de Turner et al. (1994) e confirmam que a duração total do magmatismo na Bacia do Paraná foi de 10 - $12 \mathrm{Ma} \mathrm{com} \mathrm{uma} \mathrm{migração} \mathrm{do} \mathrm{magmatismo} \mathrm{de} \mathrm{direção} \mathrm{NW} \mathrm{para}$ SE. A datação mais próxima da área de ocorrência de arenitos asfálticos localiza-se à nordeste da área, na região de Pitanga (SP), onde apresentam a datação de um derrame

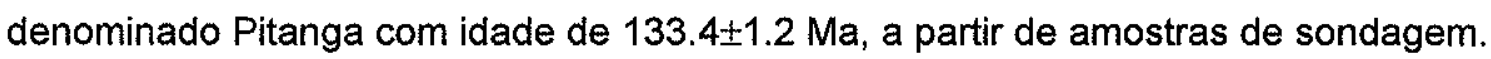

Para a área de estudo essas variações de idade não estão claramente definidas. A correta definição da idade do evento que causou a intrusão dos diques de rochas básicas associados aos arenitos asfálticos auxiliará no entendimento do processo de migração e acumulação dos hidrocarbonetos na área.

Para Yoshida \& Gama Jr. (1982), a presença de rochas básicas nunca representou um fator negativo à potencialidade da Bacia do Paraná. Os autores afirmam que a presença de soleiras de diabásio representa um fator positivo de máxima importância à ocorrência de acumulações de hidrocarbonetos. Este fato positivo se concretiza em três sentidos (Yoshida \& Gama Jr., 1982):

a. na geração, como resultado do calor introduzido nas rochas geradoras, favorecendo as reações termoquimicas de transformação de matéria orgânica em hidrocarbonetos;

b. na acumulação, pela presença de fraturas que emprestam ao diabásio características de reservatório;

c. no selamento de estruturas, quando o diabásio se apresenta em forma de diques associados a soleiras de diabásio maciço.

Conforme os estudos geoquímicos realizados pelo Paulipetro (Yoshida \& Gama Jr., 1982), seguindo as idéias de Oliveira (1971 apud Yoshida \& Gama Jr 1982), a geração seria de idade tardia, no máximo $140 \mathrm{Ma}$. A comprovação definitiva teve lugar com a descoberta de gás em fraturas de diabásio no poço de Cuiabá Paulista. Acredita-se que, embora a geração tenha se iniciado com o acréscimo térmico introduzido na bacia pelo vulcanismo Serra Geral, o soterramento decorrente foi suficiente para situar os geradores nas janelas naturais de óleo ou gás.

\subsection{Orogenia La Ventana}

Há evidências de um evento orogênico Permo-Triássico que atingiu principalmente o sul do continente Sul Americano. A região melhor preservada para o estudo desta orogenia compreende as Sierras Australes que também são conhecidas como Sierra de La Ventana (Figura 2.5). Para o estudo dos arenitos asfálticos, o conhecimento das características deste 
evento é importante para o entendimento de estruturas presentes na área de estudo que podem estar diretamento relacionadas ou mesmo terem sido reativadas.

Segundo Cobbold et al. (1986), as Sierras Australes são um cinturão de dobramento isolado com direção NW-SE paralelo à margem do cráton La Plata, com um comprimento de aproximadamente $180 \mathrm{~km}$, localiza-se a aproximadamente $500 \mathrm{~km}$ a sul do Rio da Prata e Buenos Aires. Segundo os autores, o embasamento granítico e sua cobertura sedimentar Paleozóica sofreram intensa deformação sob condições da fácies xisto-verde.

Segundo Rosselo et al. (1997), a idade da deformação das Sierras Australes é Permiana e Triássica Inferior. Isto é baseado em eventos metamórficos indicados pela

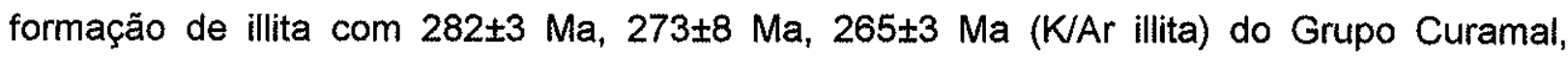
Siluriano. Evidência de magmatismo sintectônico é fornecida por datação radiométrica de $245 \pm 12 \mathrm{Ma}$ (K/Ar hornblenda) para o granito López Lecube, imediatamente a oeste das Sierras Australes.

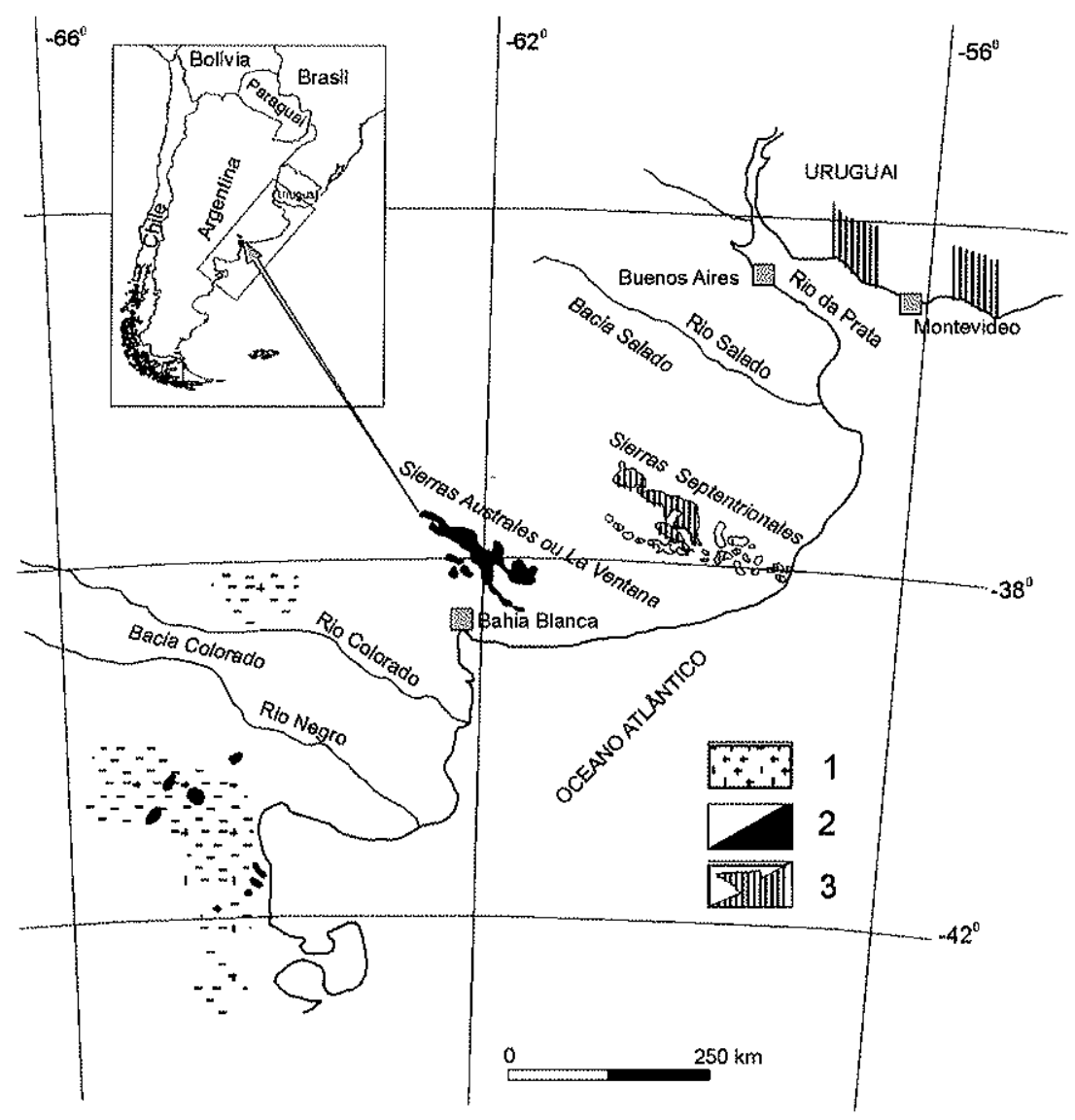

Figura 2.5: Esboço geológico da porção centro-atlântica da Argentina. (1) Plutonismo Paleozóico; (2) Cobertura sedimentar (Pré-cambriana nas Sierras Setentrionales, Paleozóica Inferior no nordeste da Patagônia e Siluro-Neopaleozóica nas Sierras Australes); (3) Embasamento cristalino Pré-cambriano. (Modificado de Cobbold et al., 1986 e Rosselo et al., 1997).

Segundo Cobbold et al. (1986), o deslocamento regional é de encurtamento NE-SW, cavalgamento para NE e transcorrência destral. Deste modo, o cinturão de dobramento sofreu convergência oblíqua (transpressão). 
Cobbold et al. (1992), a partir de investigações estruturais em bacias Paleozóicas da do sudoeste do Gondwana, concluem que a deformação intracontinental foi espacialmente generalizada durante o Permo-Triássico. Segundo os autores, o estilo de deformação variou de espessamento crustal no sul e oeste, falhamentos transcorrentes no centro até rifteamento no norte e leste. Os autores inferem uma tensão compressiva, atenuada pela distância a partir de uma margem compressiva do tipo Andina. Segundo Cobbold et al. (1992), na Bacia do Paraná a direção de contração parece ser NE-SW na porção sul, e na região norte da bacia aproxima-se de E-W. Segundo os autores, os mapas de isópacas indicam uma história complexa, com desenvolvimento de altos e baixos internos, incluindo o arco Rio Grande, arco de Ponta Grossa (direção NW-SE) e arco de Assunção (direção N-S).

\subsection{Aspectos geoquímicos}

Segundo Thomaz Filho (1982), o óleo presente na ocorrência de arenito asfáltico da Fazenda Betumita contém óleo pesado, imaturo, de alta viscosidade (aproximadamente $5^{0}$ API) com médio a alto teor de enxofre ( 2 a $3 \%$ em peso). Quadros (1982 apud Thomaz Filho 1982) faz comparação isotópica e de cromatografia líquida e gasosa do óleo da ocorrência de Anhembi com os extratos orgânicos das rochas geradoras da Bacia do Paraná. Segundo o autor, há semelhança entre os cromatogramas da ocorrência e do extrato orgânico do Subgrupo Irati (Figura 2.6). O autor sugere o Subgrupo Irati como gerador do óleo, e indica o óleo como imaturo.

Triguis (1986) descreve a análise de 3 amostras de arenitos asfálticos de afloramentos no Estado de São Paulo, nas ocorrências de Jacutinga, Piapara e Anhembi. Apresenta parâmetros de maturidade calculados a partir de razões isoméricas, as quais podem não ser precisas pois podem estar alteradas pelo ataque de bactérias. Segundo o autor, para as amostras de Anhembi e Piapara, há indicação que o óleo presente no arenito asfáltico está quase no final do ponto de isomeria, que corresponde ao início da zona de geração, isto indica baixo nível de maturidade do óleo extraído. $O$ autor conclui que o resultado da análise de maturidade da amostra do poço correlacionado com a mesma análise para 0 arenito asfáltico (Piapara e Anhembi) indica que o óleo foi gerado por uma fonte de maturidade juvenil. 


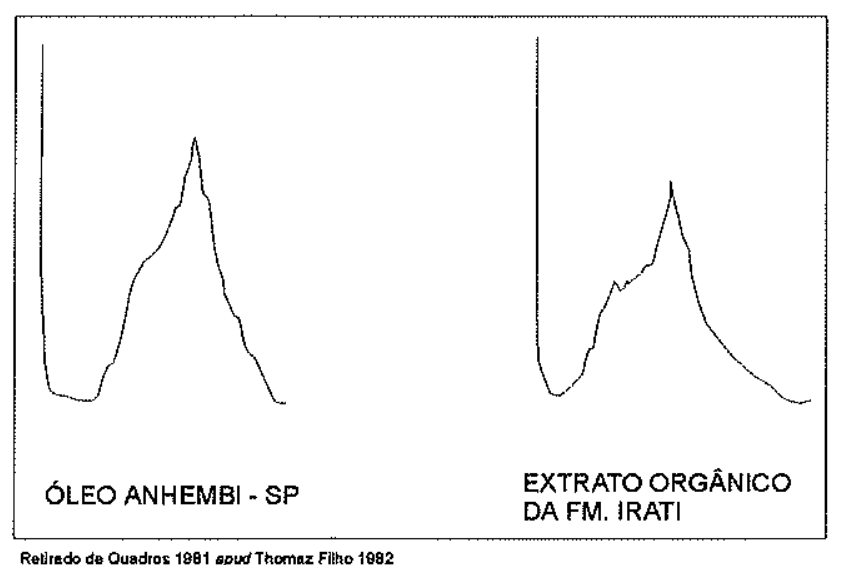

Figura 2.6: Comparação entre cromatogramas.

Segundo Quadros \& Santos (1980), os efeitos das intrusões de diabásio sobre as rochas sedimentares adjacentes se restringem às imediações dos contatos, até uma distância que não excede à metade da espessura do corpo intrusivo. Os autores estudaram os efeitos térmicos das intrusões de diabásio sobre a matéria orgânica do Subgrupo Irati nas imediações da cidade de Canoinhas (SC). Segundo os autores, a quantidade e a composição do extrato orgânico não são alterados significativamente pelas intrusões, mesmo a distâncias muito pequenas. A primeira camada de "xisto" do Subgrupo Irati não perdeu seu potencial oleogenético. A presença de intrusões nessa unidade não deve ser considerada elemento condenatório de seu aproveitamento para a obtenção do óleo de folhelho negro. Segundo Quadros \& Santos (1980), os efeitos insignificantes das intrusões de diabásio, conforme indicado na presente investigação, desautorizam considerá-las quer como mecanismo de geração de petróleo nas bacias sedimentares, quer como fator de destruição de acumulações petrolíferas preexistentes.

Segundo Goulart \& Jardim (1982), em uma avaliação geoquímica em toda a Bacia do Paraná, os dados disponíveis se mostraram extremamente afetados pelas intrusões ígneas, elas alteram localmente a matéria orgânica e provocam o aparecimento de zonas maturas ou mesmo supermaturas em meio a zonas menos evoluídas. Segundo os autores, a zona de influência é proporcional à espessura da intrusão. Estimativas dessa influência, de acordo com dados da literatura, variam de 0,5 (Quadros \& Santos, 1980) até 5 vezes a espessura (Cooper, comunicação verbal apud Goulart \& Jardim 1982).

Segundo Goulart \& Jardim (1982), em termos de quantidade de carbono orgânico, os teores médios obtidos por poço chegaram ao máximo de $3 \%$ e mínimo de $0,3 \%$, tendo sido adotado para o Subgrupo Irati o valor médio de 1\%. O mapa de isoteores de carbono orgânico permitiu o reconhecimento de duas áreas mais ricas, uma no oeste do Estado de São Paulo, noroeste do Estado do Paraná e outra ao norte dos estados de Santa Catarina e Rio Grande do Sul (Goulart \& Jardim, 1982). A região compreendida entre estas duas áreas 
mais ricas em COT (Conteúdo Orgânico Total) coincide com uma zona de menor espessura de geradoras. Ainda segundo esses autores, em termos de maturidade, todas as amostras analisadas apresentaram valores que vão desde imaturos, concentrados principalmente a leste, próximos à faixa de afloramento, até valores supermaturos mais para a parte central da bacia.

Goulart \& Jardim (1982) fizeram a comparação do mapa de maturidade de matéria orgânica com o mapa de espessuras acumuladas de rocha ígneas na formação; constataram que grande parte dos valores de supermaturidade $e$, até mesmo, alguns de maturidade são devidos à ação das intrusivas. Conforme esses, a maior atividade térmica ocorreu à época do evento magmático, deste modo a supermaturação localizada (devido às intrusões) deve ter ocorrido neste período, com conseqüente geração de hidrocarbonetos que podem ter sido acumulados ou totalmente destruídos.

Para Mizuta et al. (1983), o óleo acumulado nas camadas mais profundas resultou do efeito de intrusões termais e também dos efeitos do soterramento normal. A migração do óleo ocorreu após a intrusão dos diabásios (Neo Cretáceo) durante a progressiva subsidência da bacia.

Segundo Araújo et al. (2000), o máximo empobrecimento no COT foi de $50 \%$ nos contatos do Subgrupo Irati com intrusões ígneas; segundo os autores, os valores de COT gradualmente aumentam com a distância dos contatos com as intrusivas. O empobrecimento médio da rocha geradora na zona de transição é de $30 \%$. Os autores determinaram que soleiras de espessura igual a da rocha geradora causam um decréscimo máximo de $30 \%$ no valor do COT, este foi o valor médio observado pelos autores em poços monitorados ao longo da borda da Bacia do Paraná. Os autores também calcularam o volume de hidrocarbonetos disponíveis para migração por unidade de área (Figura 2.7), os valores variam de zero à 3500 $\mathrm{m}^{3} / \mathrm{km}^{2}$.

Santos et al. (2003) apresentam resultado de estudo de mecanismo de transferência de calor no contato entre soleiras e sedimentos do Subgrupo Irati. A partir da composição isotópica de amostras no contato soleira/encaixante, os autores concluem que não há troca isotópica entre as litologias. Ao utilizar análise de REE para avaliar as possiveis interações geoquímicas entre a soleira e a encaixante, novamente, concluíram que não há interação entre o magma e a rocha encaixante tanto na parte superior quanto na inferior da soleira. Desse modo, a falta de massa significativa trocada entre a soleira e a encaixante sugerem que o mecanismo de aquecimento foi principalmente controlado por difusão térmica. 


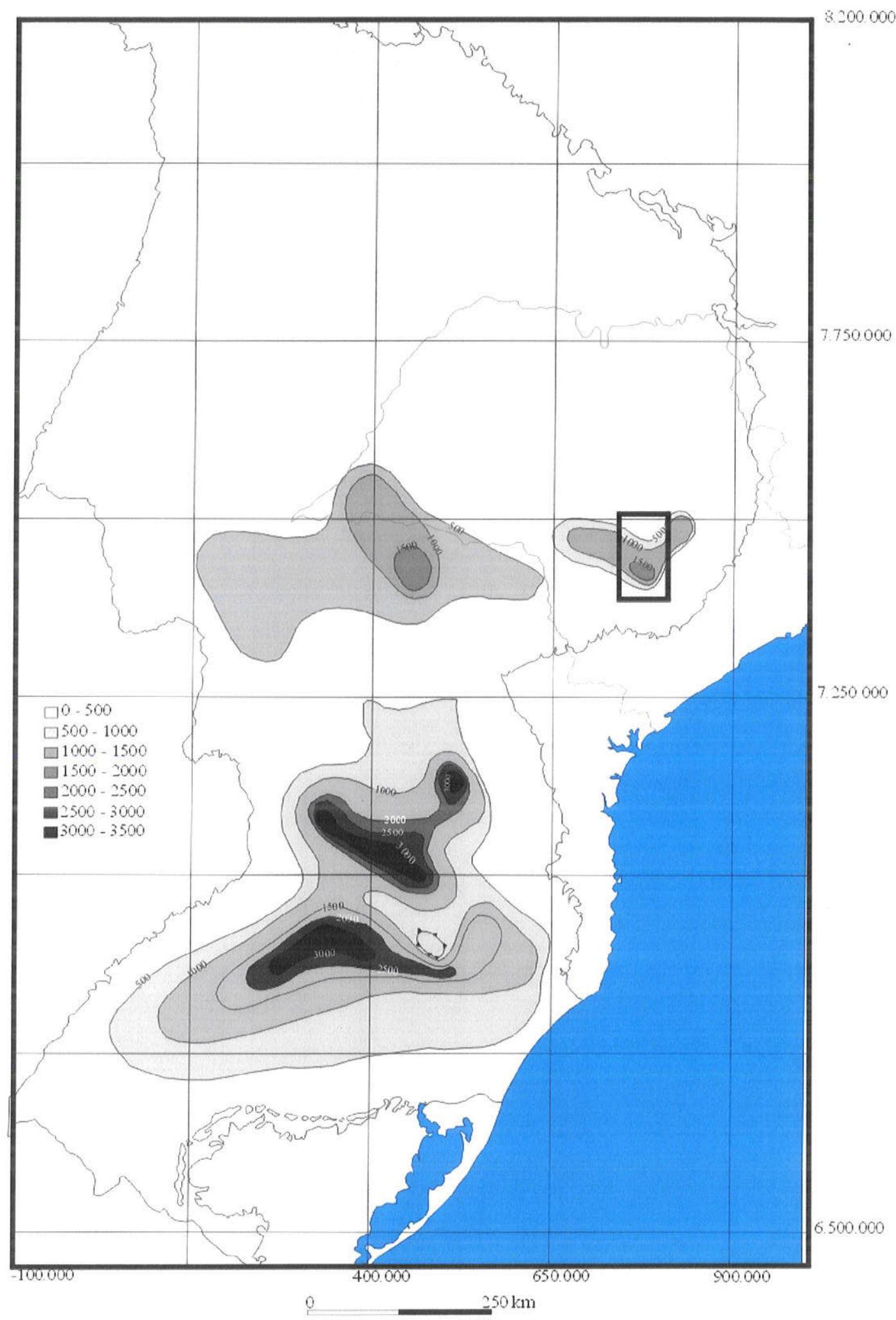

Figura 2.7: Mapa de volume de hidrocarbonetos disponíveis para migração $\left(\mathrm{m}^{3} / \mathrm{km}^{2}\right)$. A área de estudo está assinalada pelo retângulo preto (Segundo Araújo et al. 2000). 


\subsection{Gravimetria}

Quintas (1994) estudou o arcabouço da Bacia do Paraná utilizando dados geofísicos, especialmente gravimetria. Segundo a autora, o alto gravimétrico da porção centro-oeste do Estado de São Paulo, indica que no Carbonifero a distribuição dos esforços provocou falhamentos com orientação distinta (subperpendicular) àqueles criados ou reativados no Ordoviciano; essas estruturas são recorrentes em correspondência aos paralelos $22 \mathrm{~S}$ (alinhamento Tietê, Coimbra et al., 1977), 25 S (Arco de Ponta Grossa) e 28 S (alinhamento Torres-Pousadas, Leinz 1949, apud Quintas 1994). Diante da coincidência de centros espessos de sills, no centro-oeste de São Paulo, sugere-se que os prováveis falhamentos NW-SE, associados ao evento do estiramento, durante o Carbonífero, tenham sido reativados

no Cretáceo Inferior. A conseqüente atividade hidrotermal do Cretáceo Superior em correspondência ao alinhamento do Tietê, foi descrita por Coimbra et al. (1977).

Quintas (1994), a partir de dados gravimétricos, discrimina zonas de maior fraqueza geradas no Ordoviciano e no Carbonífero. Segundo a autora, essas zonas de litosfera enfraquecida no Ordoviciano e Carbonífero teriam sido, num novo quadro de esforços tectônicos do Cretáceo Inferior, sítio de propagação dos dutos do magmatismo, indicado pela localização dos sills intrudidos nos sedimentos da bacia. Ainda segundo a autora, a seqüência de baixos gravimétricos de direção NE-SW, a partir do Cinturão Ribeira, pode indicar a presença de granitogêneses e de depocentros de metassedimentos sugerindo a continuação do Cinturão Ribeira sob as coberturas da Bacia do Paraná.

\subsection{Aeromagnetometria}

Ferreira (1982) desenvolve estudo das respostas magnéticas dos diques de rocha básica da Bacia do Paraná na região do Arco de Ponta Grossa. Segundo o autor, uma análise global das assinaturas dos diques demonstra que 0 alinhamento possui um comportamento heterogêneo relativamente às direções estruturais, polaridades e incidência de diques. Essas particularidades estruturais-magnéticas sugerem que o conjunto de fenômenos responsáveis pelo condicionamento tectônico dos diques deu-se em intervalos diferentes do tempo geológico. A maior densidade de diques concentra-se no segmento entre Taquarituba e Ourinhos, onde observa-se perturbações provocadas por falhamentos na direção NE-SW, especialmente em Ourinhos, Fartura, Joaquim Távora-Quatigá, PirajuSarutaiá e Jacarezinho-Ribeirão Claro. Muitas dessas áreas correspondem a estruturas menores mapeadas, condicionadas ao alinhamento e relacionadas com zonas de relevo magnético suave.

Segundo Ferreira (1982), a região à nordeste do alinhamento de Guapiara caracterizase por apresentar um número pequeno de falhas relativamente aos outros compartimentos 
estruturais. Nesta região, a estrutura regional pode ser representada, de acordo com Fúlfaro et. al. (1982), por três homoclinais denominados de Paranapanema, Médio Tietê e Mogi Guaçu com orientações ENE, N e NE, respectivamente.

De acordo com Ferreira (1982), várias estruturas geológicas relacionam-se ao Arco de Ponta Grossa. Estas estruturas são citadas por Fúlfaro (1980 apud Ferreira, 1982) e foram compiladas a partir de dados de outros autores. Estas estruturas são falhas de Santa RitaTambaú, Descalvado-Santa Cruz da Conceição, Paranapanema-Angatuba, horst de Pau D'Alho e os sistemas de falha da Serra da Fartura e do Rio das Pedras-Ipeúna. Também há estruturas com fechamento em camadas Permianas: Urucaia, Pitanga, Artêmis, Anhembi e Gibóia (relativas ao homoclinal Tietê), Torrinha, Guareí, Jacu, Jacutinga, Neblina e Ribeirão Grande (relativas ao homoclinal do Paranapanema). Segundo Ferreira (1982), a maioria destas estruturas devem estar controladas pela atividade do alinhamento Guapiara. Durante a Reativação Pós-Paleozóica, o soerguimento e abatimento de blocos de falha condicionados ao alinhamento é interpretado como fenômeno gerador das estruturas menores mapeadas, embora Ferreira et al. (1981) acreditem que muitas delas pudessem estar consolidadas em tempos paleozóicos, com base na longa história tectônica deste alinhamento estrutural. 


\section{CAPÍTULO 3}

\section{MATERIAIS E MÉTODOS}

Utilizou-se um sistema de informação geográfica para reunir, organizar e analisar os dados de topografia, sensoriamento remoto, aerogeofísica, magnetometria, gravimetria, geocronologia e anotações de campo.

\subsection{Dados levantados e coleta de informações}

\subsubsection{Dados geológicos}

Foram utilizados mapas e dados geológicos de diversas fontes, como artigos científicos, relatórios técnicos e teses. Destacam-se as principais fontes de informação disponiveis para uso público:

- Franzinelli (1972) tese de doutorado IG-USP - mapa geológico na escala 1:100.000, localização de ocorrências e contorno estrutural;

- Steveaux et al. (1980) - relatório Paulipetro 016/80 - mapas geológicos na escala 1:50.000;

- Aboarrage \& Lopes (1986) - Projeto Borda leste da Bacia do Paraná (CPRM/DNPM) mapa geológico na escala 1:100.000.

\subsubsection{Fotos aéreas}

Foram obtidas no Laboratório de aerofotogrametria, da Faculdade de Filosofia, Letras e Ciências Humanas da USP, um conjunto de 98 fotos aéreas, escala 1:25.000 de 1962. As fotos foram separadas por área de ocorrência de arenitos asfálticos. A fotointerpretação desse material serviu de apoio ao trabalho de semi-detalhe.

\subsubsection{Levantamento de campo}

O trabalho de campo envolveu dois objetivos principais: localização e caracterização geológica das ocorrências de arenitos asfálticos e reconhecimento geológico da área de afloramento das ocorrências.

Durante a fase de reconhecimento geológico da área, procedeu-se a um levantamento regional do contato da Formação Teresina com a Formação Pirambóia para definir os pontos de contato e as respectivas cotas de afloramento (obtidas em cartas topográficas 1:10.000). Este procedimento também auxilia na detecção de estruturas, principalmente falhamentos que são dificilmente observáveis em afloramentos. Também, durante a fase de levantamento 
regional foi possivel realizar medições sistemáticas de padrões de fraturamento, que serviram à orientação de trabalhos de semi-detalhe posteriores.

O levantamento das ocorrências de arenitos asfálticos envolveu primeiramente a compilação dos dados obtidos na literatura. A partir da indicação destes dados, as ocorrências são procuradas em campo, inclusive considerando a indicação de moradores da região, este procedimento possibilitou inclusive a descoberta de novas ocorrências não catalogadas. Em todas as ocorrências visitadas foi feita uma descrição preliminar da rocha armazenadora, medição de estruturas geológicas, observação do entorno em relação à configuração geológica e topográfica.

3.2 Base planialtimétrica e digitalização de dados topográficos

Foram digitalizadas as seguintes cartas topográficas 1:50.000: Guarei, Angatuba, Bofete, Conchas, Anhembi, Botucatu, Santa Maria da Serra e Barra Bonita (Figura 3.1).

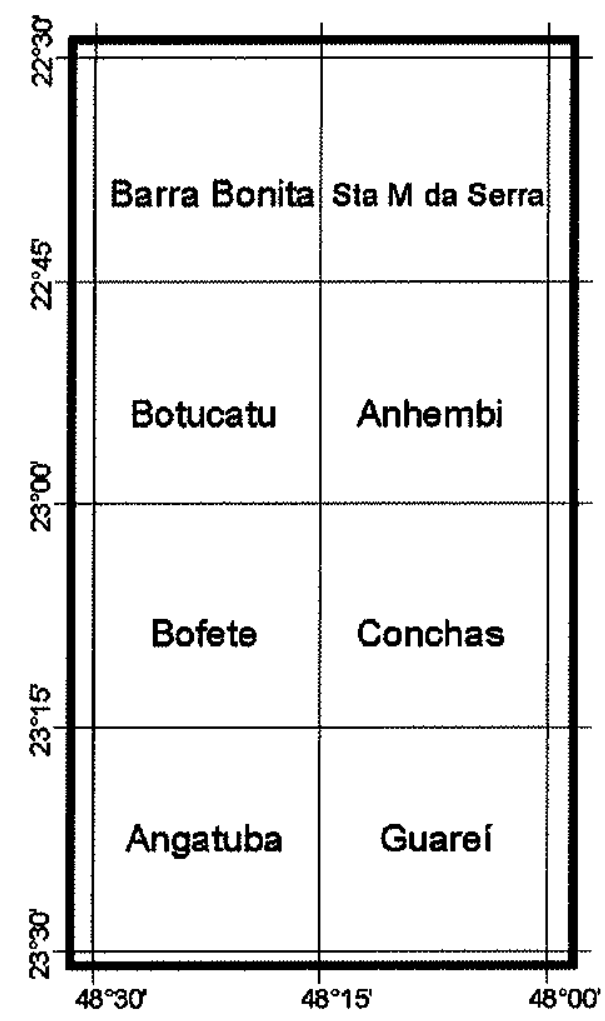

Figura 3.1: Articulação das cartas topográficas 1:50.000 utilizadas.

As curvas de nível foram convertidas em Modelo Numérico de Terreno (MNT) a partir da utilização de um algoritmo de geração de superfícies (TIN - triangular irregular network). Além das curvas de nivel, foi digitalizada toda a rede de drenagem da área de estudo para execução da interpretação morfoestrutural e interpretação de feições retilíneas de drenagem 
e alinhamentos de drenagem. Também foi digitalizado parte dos mapas geológicos DAEE/UNESP 1:250.000, folhas Botucatu e Campinas.

O método de digitalização escolhido foi o de conversão dos mapas para formato digital e vetorização semi-automática (auxiliada por software) das imagens.

\subsection{Dados gravimétricos}

O princípio das medições com os gravímetros é baseado nas pequenas mudanças no peso de uma massa conhecida, toda vez que ocupamos uma estação com localização diferente. Esta mudança no peso da massa ocorre devido às variações no campo de gravidade da terra. O gravímetro é assim uma balança de extrema sensibilidade.

O gal é a unidade utilizada nas medidas, cuja dimensão equivale à aceleração de 1 $\mathrm{cm} / \mathrm{seg}^{2}$. Os corpos de minérios e as estruturas geológicas de interesse na prospecção, tanto mineral como de petróleo, ou ainda em engenharia, produzem modificações ou anomalias no valor de g que não excedem alguns miligals. Na prática isso implica na necessidade de se medir valores da ordem de $0,01 \mathrm{mgal}$ de precisão.

$\mathrm{Na}$ área de estudo, a gravimetria pode ser utilizada para se estudar o comportamento do embasamento e de grandes compartimentos tectônicos.

Um cuidado a ser observado em levantamentos gravimétricos é a deriva instrumental. Segundo Sá (1994), a deriva instrumental é a composição das derivas estática e dinâmica ocorridas no percurso. A deriva estática de uma linha gravimétrica, representa a soma das variações ocorridas nas interrupções da linha, geralmente com duração maior que uma hora. A deriva dinâmica corresponde à variação ocorrida no período em que o gravímetro permanece em movimento, que equivale ao tempo decorrido entre a primeira e a última leituras da linha, menos o tempo de deriva estática.

Optou-se pelo levantamento de linhas gravimétricas com abertura e fechamento no mesmo dia.

Deste modo, procurou-se minimizar os efeitos das derivas dinâmica e estática. A redução dos dados ao final do dia permitiu a verificação de pontos anômalos durante o levantamento.

A primeira fase do levantamento de dados gravimétricos envolveu a compilação dos dados existentes. Foi obtido um levantamento gravimétrico executado na área de estudo e disponível no banco de dados gravimétricos do Estado de São Paulo do Instituto de Astronomia, Geofísica e Ciências Atmosféricas da USP.

Este levantamento conta com 1082 pontos gravimétricos com um espaçamento médio de aproximadamente $5000 \mathrm{~m}$. As tabelas de dados contêm as anomalias Bouguer já calculadas (não foram obtidos os valores de leitura do gravímetro). Este levantamento foi executado utilizando-se um gravímetro Lacoste \& Romberg. 
Também foram feitos levantamentos de campo na região do Domo de Jacu e Anhembi. Neste trabalho também foi utilizado um gravímetro Lacoste \& Romberg do Instituto de Geociências e Ciências Exatas da UNESP.

\subsection{Aeromagnetometria}

De acordo com Vasconcellos et al. (1994), as variações do campo geomagnético principal são produzidas em maior ou menor grau em função da presença de minerais magnéticos nas rochas. Os principais minerais magnéticos são: pirrotita, ilmenita e magnetita, além da hematita ulvospinélio e pseudobroquita.

Para a área de estudo a aeromagnetometria pode ser utilizada principalmente na detecção de corpos de rochas básicas, além de falhamentos. Estes falhamentos podem ou não conter minerais magnéticos.

Durante o processamento dos dados magnéticos é importante considerar a posição geográfica do levantamento em relação aos pólos e/ou equador, além da qualidade dos dados em relação ao nivelamento das linhas de vôo e ruídos presentes no banco de dados. Deste modo, o processamento de dados considerou o processamento de redução ao pólo, micronivelamento, filtragem direcional e geração de imagem de sinal analítico e derivada vertical.

Os dados utilizados fazem parte do projeto Botucatu contratado pela Paulipetro em 1980 para avaliação dos blocos 46, 47, 48 e 49 concedidos pela Petrobrás para prospecção de petróleo. Foi utilizado o aeromagnetômetro de prótons modelo G-801/3 da GEOMETRICS, cujo sensor foi montado na cauda ("stinger") da aeronave Bandeirante - EMB 110\$1, cuja velocidade de operação é de $350 \mathrm{~km} / \mathrm{h}$. As principais características do levantamento Botucatu são apresentadas na Tabela 2.

Tabela 2: Características do projeto Botucatu.

\begin{tabular}{|l|l|}
\hline Período & 06 a 07/80 \\
\hline Total de Perfis & $25.745 \mathrm{~km}$ \\
\hline Intervalo (AM) & $100 \mathrm{~m}$ \\
\hline Altura de Vôo & $450 \mathrm{~m}$ \\
\hline área Total & $46.000 \mathrm{~km} 2$ \\
\hline Direção (LV) & $\mathrm{N}-\mathrm{S}$ \\
\hline Espaçamento (LV) & $2 \mathrm{~km}$ \\
\hline Direção (LC) & $\mathrm{E}-\mathrm{W}$ \\
\hline Espaçamento (LC) & $20 \mathrm{~km}$ \\
\hline
\end{tabular}




\subsection{Sensoriamento Remoto}

O sensoriamento remoto trata da medição e registro de energia eletromagnética refletida ou emitida pela superfície do planeta e da atmosfera, além do relacionamento de tais medidas com a natureza, com a distribuição dos materiais e com as condições atmosféricas (Paradella, 1998).

Foram utilizadas imagens em formato digital do satélite Landsat 7 equipado com o sensor ETM+ (Enhanced Thematic Mapper Plus). A imagem utilizada tem órbita/ponto 220/76 de 29 de novembro de 1999. Foram utilizadas 6 bandas espectrais com 30 metros de resolução e 1 banda pancromática de 15 metros de resolução.

Para o emprego das imagens digitais foram utilizadas diversas técnicas inerentes ao manejo de dados digitais de sensores remotos, entre estas destacam-se os procedimentos de pré-processamento (correções atmosféricas e geométricas) e os procedimentos de processamento como a aplicação de técnicas de realce, pseudo-cor, transformação IHS (Intensity/intensidade, Hue/matiz, Saturation/saturação) e componentes principais. Devido à excelente qualidade das imagens (Landsat $7 \mathrm{ETM+}$ ), não foi necessário executar procedimentos de correção radiométrica, tais como os de eliminação de ruídos.

A partir da descrição sucinta do processamento, citado anteriormente, pode-se notar que a aplicação de sensoriamento remoto nesta pesquisa tem sido feita no sentido de obter cartas imagem com o intuito de auxiliar o posicionamento no campo, análise textural de elementos geológicos de interesse e complementação da rede de drenagem (IBGE, 1:50.000) visando a interpretação morfoestrutural.

\subsection{Morfoestruturas}

Segundo Mattos et al. (1982), o termo morfoestrutura define uma estrutura presumida, identificada a partir da análise e interpretação de informações, basicamente de relevo e drenagem, caracterizada por zonas anômalas dentro de um padrão geral de distribuição dos elementos de relevo e drenagem.

O mapeamento morfoestrutural procura, a partir dos padrões de drenagem, traçar as flexuras do terreno derivadas de processos geológicos (Figura 3.2). É importante ressaltar que, para a área de estudo, o mapa morfoestrutural representa principalmente os eventos geológicos mais recentes, especialmente aqueles ocorridos a partir do Terciário. Entretanto, devido a sucessivas reativações de estruturas antigas podem ser reconhecidas feições correlacionáveis ao embasamento da bacia e à Reativação Pós-Paleozóica. 


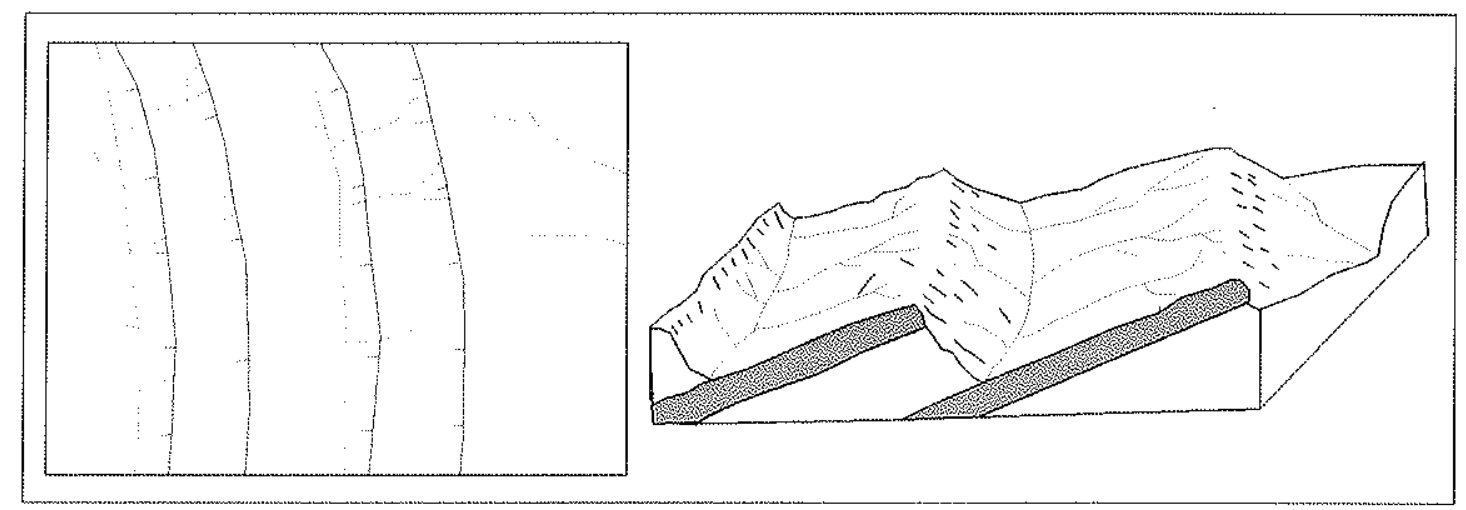

Figura 3.2: Esquema de traçado de morfoestruturas (linhas vermelhas).

O traçado a partir da geometria de drenagem permite visualizar a conformação estrutural da área e indicar as regiões de alto e baixo estrutural. As linhas traçadas podem ser cotadas com valores arbitrários afim de se construir um modelo numérico de terreno que permita uma melhor visualização da conformação estrutural interpretada.

Um dos primeiros passos na interpretação morfoestrutural é de se reconhecer as formas anômalas de drenagem (Figura 3.3). Crepani (1987) cita algumas formas anômalas mais importantes, pela sua expressão em imagens e relacionamento com estruturas geológicas.

Segundo Crepani (1987), a interpretação das formas anômalas da rede de drenagem e dos arranjos formados por diferentes combinações entre elas, permite que se infira o seu significado geológico, uma vez que a intensidade de estruturação dessas formas representa o grau de controle estrutural a que estão submetidas. Dessa forma, segundo o autor, as anomalias morfoestruturais são constituídas pelo arranjo simultâneo de formas anelares, radiais e assimétricas de drenagem como produto de condicionamento da rede hidrográfica por estruturas de sub-superfície de bacias sedimentares. Tais estruturas caracterizam-se por flexuras anelares ou elípticas nas camadas associadas a mergulhos divergentes no caso de domos, ou convergentes no caso de depressões estruturais. 


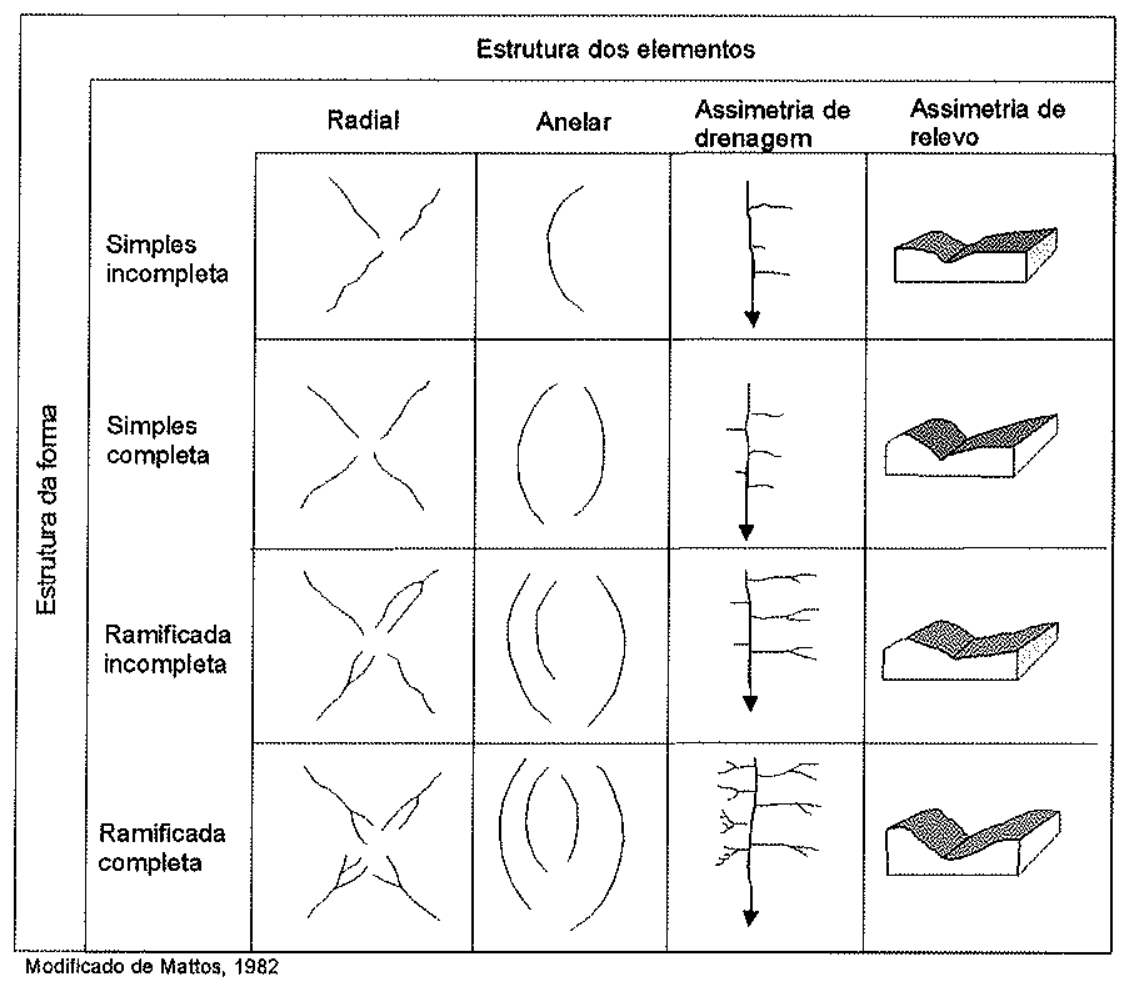

Figura 3.3: Classificação das formas anômalas de drenagem.

\subsection{Lineamentos estruturais interpretados}

O termo lineamento foi originalmente definido por Hobbs (1912, apud Veneziani, 1987) para caracterizar as relações espaciais de feições, tais como cristas, bordas de áreas elevadas, alinhamentos de contatos geológicos ou tipos petrográficos, ravinas ou vales e de fraturas ou zonas de falhas visíveis como tais. Segundo Veneziani (1987), pode ser empregado como designativo de feições definidas por alinhamentos de relevo e drenagem, os quais englobam as formas definidas por Hobbs.

A distinção entre lineamentos estruturais e falhamentos, na interpretação dos produtos de sensoriamento remoto, é necessária devido aos seguintes fatores (Veneziani, 1987):

- Os lineamentos não se restringem ao desenvolvimento de apenas um tipo de movimento tectônico, ao longo de toda sua extensão, ou durante o decorrer dos diferentes ciclos ou fases tectônicas que afetaram uma determinada área;

- Uma zona de falha pode dar origem a diversos lineamentos paralelos a subparalelos, ou vice-versa, isto é, várias fraturas associadas a uma zona de falha podem dar origem a apenas um lineamento, distinguivel nos produtos de sensoriamento remoto. 


\subsection{Zonas de juntas}

O termo fratura, segundo Ramsay \& Huber (1987), é definido como um plano de ruptura onde a coesão na rocha foi perdida, este plano pode corresponder às juntas ou falhas. As juntas são definidas como planos de quebra onde os dois lados do plano não sofreram deslocamento apreciável. A falha é definida quando há deslocamento apreciável.

Segundo Soares \& Fiori (1976), as zonas de fraturamento, por serem mais facilmente atacadas pelos processos meteóricos e erosivos, constituem zonas de desenvolvimento preferencial de linhas de drenagem retilíneas. Aos elementos de drenagem fortemente estruturados (disposição regularmente ordenada), retilíneos ou em arco, denomina-se, segundo Soares \& Fiori (1976), lineações de drenagem e estas são interpretadas como traços de fratura.

Resumidamente conclui-se, conforme Soares \& Fiori (1976), que as fraturas (ou juntas) são refletidas através dos traços de fratura ou lineações de drenagem retilíneas. Os traços de fratura correspondem a zonas de concentração de juntas.

Lattman \& Matzike (1961 apud Soares \& Fiori, 1976) consideram o valor de $1.600 \mathrm{~m}$ para o limite máximo do tamanho do traço. Northfleet et al. (1971) estabelecem o limite em $3.500 \mathrm{~m}$. Segundo Soares \& Fiori (1976), a partir deste limite, as fraturas sofrem deslocamentos como blocos.

Plicka (1974) define zonas de juntas como zonas de concentração de fraturas mais ou menos paralelas. Segundo o autor, na maioria dos casos, ocorrem dois sistemas perpendiculares entre si. A largura dessas zonas de juntas varia de 0,5 a $6 \mathrm{~m}$. As juntas nestas zonas têm um mergulho de 70 a $90^{\circ}$, e as zonas estendem-se por grandes áreas. As zonas de juntas de qualquer sistema ocorrem repetidamente em distâncias de poucos metros a dezenas de metros entre si, desta forma constituindo um conjunto de zonas de junta. $O$ termo "conjunto de zonas de juntas" é, definido por Plicka (1974), como uma série de zonas de juntas paralelas entre si e com uma gênese comum.

Destacam-se, dos trabalhos de Plicka (1974) e Nickelsen (1974), características importantes das zonas de juntas que podem ser utilizadas na prospecção de mineralizações:

- os conjuntos de zonas de juntas podem emergir de rochas mais antigas e se estender verticalmente através de rochas sobrejacentes mais novas;

- os padrões de fraturamento são cumulativos e persistentes;

- alguns conjuntos de zonas de juntas, representados por grandes lineamentos têm persistido desde o Pré-Cambriano, afetando a sedimentação, a tectônica, a expressão fisiográfica e até mesmo a localização de depósitos minerais.

Segundo Veneziani (1987), a distribuição generalizada e por grandes distâncias mostra que os conjuntos de zonas de juntas são feições geológicas de significado regional, 
essencialmente independentes de variações litoestratigráficas locais e da atitude dos estratos, embora estes dois últimos fatores exerçam controle sobre a freqüência.

Baseando-se em metodologia de Veneziani (1987), a partir de um mapa com as curvas de isodensidade de fraturamento, ou mesmo uma grade com a freqüência de fraturamento, pode-se interpretar um mapa de eixos de distribuição de fraturamentos na superfície. Segundo Aliyev (1979), estes eixos representam direções de fraqueza precedentes à instalação dos sistemas de fraturas, generalizadamente observados $e$, conseqüentemente, influem e favorecem um acréscimo na densidade de fraturamentos de gerações posteriores, ao longo dos mesmos.

\subsection{Lineamentos e zonas de juntas}

Segundo Veneziani (1987), ao analisar as relações entre lineamentos e zonas de juntas, pode-se observar os seguintes aspectos:

- os feixes associam-se aos lineamentos mais expressivos de acordo com a verificação de Plicka (1974);

- as direções dos feixes podem ser paralelas aos lineamentos, possivelmente indicando reflexos na superfície da propagação de falhamentos profundos com movimentação relativa vertical;

- as direções dos feixes e dos lineamentos podem formar entre si um ângulo agudo. Neste caso, as juntas que dão origem ao feixe podem tratar-se de "pinnate fractures" descritas por Hobbs et al. (1976) indicando a direção do movimento relativo.

Segundo Veneziani (1987), pode haver uma não correspondência dos dados de campo com as zonas de juntas interpretadas, que pode ser justificada conforme segue:

A - para o caso da direção observada no campo e inexistência de feixe coincidente, duas situações podem ser consideradas. A primeira e mais constante é quando existe um ou mais traços de fraturas no mapa correspondente, exibindo a mesma direção da medida de campo, porém não em número/concentração suficiente para determinar o traçado de um feixe na escala de trabalho. A segunda é mais dificil de ocorrer, a não identificação dos traços correspondentes às medidas de campo, deve estar ligada às próprias limitações dos produtos/imagens utilizados, principalmente a resolução espacial (por exemplo, há dificuldade na deteç̧ão de estruturas leste-oeste com imagens Landsat TM);

B- Para o caso de existência de feixe e inexistência do dado de campo, observa-se que esta situação é mais difícil de ocorrer. Deve ligar-se a problemas de análise de campo, principalmente à falta de bons afloramentos ao longo dos trechos percorridos. Levantamentos mais detalhados devem resolver o problema; 
C- Diferenças entre as direções medidas no campo e o azimute dos feixes. No interior de um feixe pode haver variações de $10^{\circ}$ ou mais nas direções dos traços de fraturas, com um limite máximo estabelecido de $15^{\circ}$.

Veneziani (1987) verificou que apenas traços de fraturas representantes de zonas de juntas, mostram tendência de distribuição em feixes na área estudada. Juntas assistemáticas (ou não sistemáticas), e/ou sistemas correlacionáveis exclusivamente aos dobramentos, não dão origem a feixes que possam ser identificados na escala de trabalho (1:250.000).

\subsection{Falhas em arenitos porosos}

Os falhamentos em arenitos porosos são caracterizados por algumas peculiaridades. Devido ao comportamento frágil da rocha, dificilmente são encontrados planos ou espelhos de falha. Do mesmo modo, indicadores cinemáticos na forma de estrias também são raros. Diversos autores descrevem o comportamento dos mecanismos de falhamento em arenitos porosos como Aydin \& Johnson (1983), Underhill \& Woodcock (1987), Antonellini et al. (1994), Fossen (1997), Davis et al. (1999) entre outros.

Aydin \& Johnson (1983) descrevem um desenvolvimento seqüencial no processo de falhamento em arenitos porosos. Segundo estes autores, três formas de falhamento são reconheciveis: bandas de deformação, zonas de bandas de deformação e superfícies de descolamento.

As bandas de deformação são caracterizadas pela espessura milimétrica e pelo comprimento métrico. Estas estruturas são extremamente delgadas e apresentam um alto grau de silicificação, cominuição e deslocamento dos grãos. Outra característica importante é a diminuição expressiva da permeabilidade e porosidade nestas estruturas.

A partir da geração de novas bandas de deformação de mesma atitude e subparalelas há a geração de zonas de bandas de deformação. Estas zonas são caracterizadas pela grande quantidade de bandas de deformação em uma área restrita (poucos metros quadrados). Nas zonas de bandas de deformação, o desenvolvimento de novas bandas parece interferir no crescimento das bandas mais antigas. Isto é concluído a partir das deformações nas terminações das bandas de deformação formando padrões em forma de "rabo de cavalo", anastomosados, curvados e, também, em forma de olhos e sigmóides. Estas deformações são úteis em estudos estruturais de cinemática e podem auxiliar o entendimento das bandas de deformação em relação às estruturas regionais.

As bandas de deformação e zonas de bandas de deformação (Aydin \& Johnson, 1983) são caracterizadas pelos pequenos rejeitos em cada banda. Entretanto, a acumulação destes rejeitos pode resultar em deslocamentos consideráveis de ordem métrica. A principal distinção entre bandas de deformação e falhamentos de pequeno rejeito é a falta de descontinuidades na forma de superfícies discretas. As bandas de deformação têm zonas de 
deformação milimétrica onde verificam-se variações da granulometria do arcabouço, rotação e cominuição de grãos. Quando há progressão do processo deformacional culmina-se, segundo Aydin \& Johnson (1983), com o desenvolvimento de estruturas do tipo superfícies de descolamento (slip surfaces), na verdade estas superfícies têm rejeito apreciável e são caracterizadas como falhas. Segundo Aydin \& Johnson (1983), superfícies de descolamento são estruturas de deslocamento e descontinuidade formadas principalmente em áreas de alta concentração de bandas de deformação. Além disso, estas estruturas acomodam grandes deslocamentos da ordem de várias dezenas de metros.

Bandas de deformação e zonas de bandas de deformação são estruturas chave no entendimento do arcabouço estrutural de reservatórios siliciclásticos. Estas estruturas são caracterizadas como "falhas selantes" e o estudo de seu comportamento petrofísico é importante para o entendimento das variações de permeabilidade e porosidade nestes reservatórios. Além disso, estas estruturas demonstram arranjos geométricos relacionados à sua gênese que podem funcionar como bons indicadores cinemáticos e de regime tectônico.

\subsection{Geocronologia pelos métodos $\mathrm{K} / \mathrm{Ar}$ e ${ }^{40} \mathrm{Ar} /{ }^{39} \mathrm{Ar}$}

De acordo com McDougall \& Harrison (1988), o método K/Ar é baseado na ocorrência natural de isótopo radioativo de potássio $\left({ }^{40} \mathrm{~K}\right)$. Este isótopo de potássio tem um decaimento dual para ${ }^{40} \mathrm{Ca}$ e para ${ }^{40} \mathrm{Ar}$, e uma parte que fornece argônio radiogênico $\left({ }^{40} \mathrm{Ar}\right)$ como produto filho que é a base para o método de datação K-Ar a partir da sua acumulação ao longo do tempo geológico.

Segundo McDougall \& Harrison (1988), o método ${ }^{40} \mathrm{Ar} /{ }^{39} \mathrm{Ar}$ tem como base o método KJAr. Merrihue \& Turner (1966 apud McDougall \& Harrison, 1988) reconheceram que a produção de ${ }^{39} \mathrm{Ar}$ a partir da interação de neutrons com ${ }^{39} \mathrm{~K}$ permitia um novo método poderoso de datação. Esta variação do método $\mathrm{K} / \mathrm{Ar}$ é conhecida como ${ }^{40} \mathrm{Ar} /{ }^{39} \mathrm{Ar}$. O ${ }^{39} \mathrm{Ar}$ gerado em um reator nuclear a partir de uma amostra $c 0 m{ }^{39} \mathrm{~K}$ pode ser medido em um espectrômetro de massa. $O{ }^{39} \mathrm{Ar}$ derivado do ${ }^{39} \mathrm{~K}$ é designado ${ }^{39} \mathrm{Ar}$. Da mesma maneira, outros isótopos de $\mathrm{Ar}$ podem ser medidos em um espectrômetro de massa como, por exemplo, o ${ }^{40} \mathrm{Ar}$ e $\circ{ }^{36} \mathrm{Ar}$. $\mathrm{O}^{36} \mathrm{Ar}$ é especialmente importante para a correção do ${ }^{40} \mathrm{Ar}$ não radiogênico presente no gás. Dessa maneira, segundo McDougall \& Harrison (1988), a razão ${ }^{40} \mathrm{Ar}_{\text {radiogênico }}{ }^{39} \mathrm{Ar}_{\mathrm{K}}$ pode ser obtida e é proporcional a idade $\mathrm{K} / \mathrm{Ar}$.

As vantagens do método ${ }^{40} \mathrm{Ar} /{ }^{39} \mathrm{Ar}$ são a análise de um único elemento o que dispensa a análise do $\mathrm{K}$, a qual poderia ser fonte de imprecisões analíticas ou amostrais. Outra vantagem é a maior precisão do método em relação ao método K/Ar já que as determinações com o espectrômetro de massa são mais precisas do que as determinações por outras vias como as utilizadas para o K. Entretanto, a maior vantagem do método, segundo McDougall \& Harrison (1988), é o fato de que a liberação do argônio não precisa ser feita por fusão total, 
mas pode ser feita a partir do aquecimento gradual (step heating). Desse modo, a partir das etapas de aquecimento gradual podem ser feitas determinações isotópicas que permitem a interpretação da distribuição dos isótopos de $\operatorname{Ar}$ na amostra. Dessa forma, segundo McDougall \& Harrison (1988), o método baseia-se na liberação do argônio por processos de difusão termal em um sistema de vácuo à medida que a amostra é aquecida. Durante o aquecimento gradual $0^{40} \mathrm{Ar}_{\text {radiogênico }}$ o ${ }^{39} \mathrm{Ar}$ são liberados nas mesmas proporções em função dos seus coeficientes de difusão semelhantes; dessa maneira as idades para cada extração serão constantes. Assim, os espectros de mesma idade são caracterizados como indicativos de um sistema fechado e termalmente não perturbado desde a cristalização. 


\section{CAPÍTULO 4}

\section{RESULTADOS OBTIDOS E DISCUSSÕES}

Ao longo do estudo foram encontradas 25 ocorrências de arenito asfáltico em aproximadamente 15 localidades diferentes. Entre essas, foram descritas três novas ocorrências. A apresentação dos resultados segue a cronologia de desenvolvimento da pesquisa.

\subsection{Ocorrências visitadas}

\subsubsection{Aspecto geral - principais ocorrências}

Em quase todas as ocorrências visitadas, 0 arenito asfáltico aflora em áreas desprovidas de vegetação, pois esta não encontra condições para sua implantação. Em geral, as ocorrências são encontradas em áreas íngremes, cortes do terreno ou meiaencostas. Não foram encontradas ocorrências em topo de morros ou fundo de vales. Duas ocorrências visitadas foram mineradas, a partir de escavações à céu aberto (Anhembi e Itatigue), atualmente desativadas e abandonadas.

As ocorrências têm como rocha armazenadora arenitos da Fm. Pirambóia. Apenas em uma das ocorrências, a armazenadora é composta por arenitos da Fm. Tatuí (Jacutinga).

Entre as ocorrências visitadas, a estrutura sedimentar mais comum é a estratificação cruzada de médio e grande porte. A tangência na base da estratificação é encontrada na ocorrência Betumita provavelmente devido a presença de paredes decamétricas expondo os arenitos asfálticos.

As amostras de mão são coesas devido à ação cimentante dos hidrocarbonetos. A composição dos arenitos é quartzosa com grãos variando de granulometria média a grossa, esfericidade moderada, subarredondado com contatos côncavo-convexo, a maturidade é variável entre as diversas ocorrências, submatura a matura. A distribuição do hidrocarboneto no arenito não é sempre homogênea, que proporciona diversos aspectos às amostras de mão. Estas amostras têm aspectos maciços, listrados e pintalgados. Estes aspectos são originados devido às diferentes estruturas sedimentares dos arenitos, que causam variações nas condições de permeabilidade e porosidade. Em geral, apresentam estratos centimétricos e algumas vezes milimétricos.

Nas amostras de mão notou-se a presença de pequenas fissuras preenchidas por óleo. Estas fissuras têm larguras milimétricas e comprimentos centimétricos. Ao redor destas fissuras nota-se melhor preenchimento dos poros do arenito (Figura 4.1). 

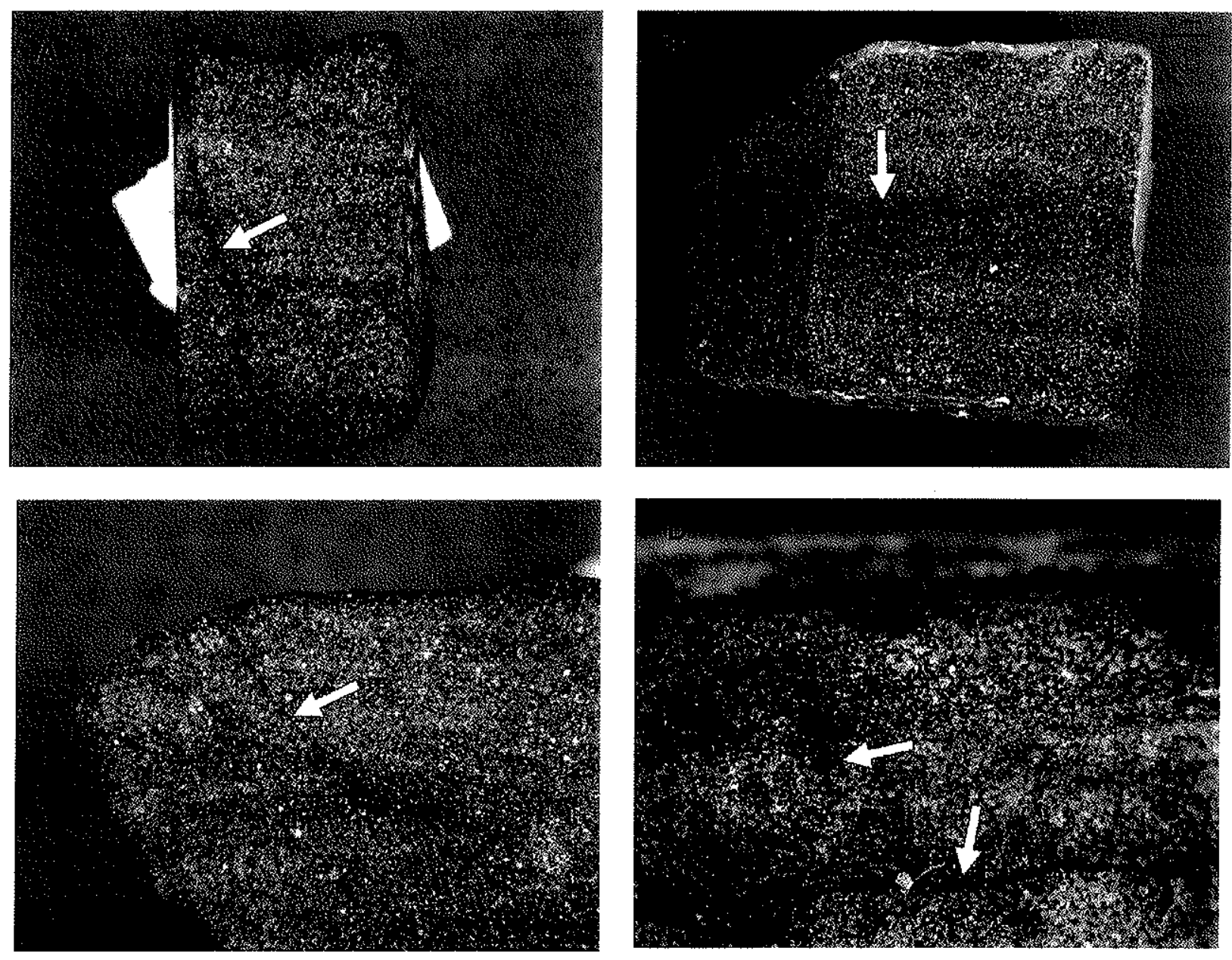

Figura 4.1: Detalhes das amostras de mão do arenito asfáltico.

Em lâmina delgada nota-se a ausência de hidrocarbonetos nas porções preenchidas por material argiloso (Figura 4.2). Em algumas lâminas nota-se a presença de porosidade não preenchida por betume, matriz ou cimento (Figura 4.2). É interessante observar a variação nos tipos de contato de grãos do arenito Pirambóia e do arenito Tatuí. A ocorrência Jacutinga, em arenito da Fm. Tatuí, tem contatos suturados e côncavo-convexos (Figura 4.3). As outras ocorrências, em arenito da Fm. Pirambóia, têm contatos mais frouxos, variando de côncavoconvexo até grãos flutuantes (Figura 4.3). 


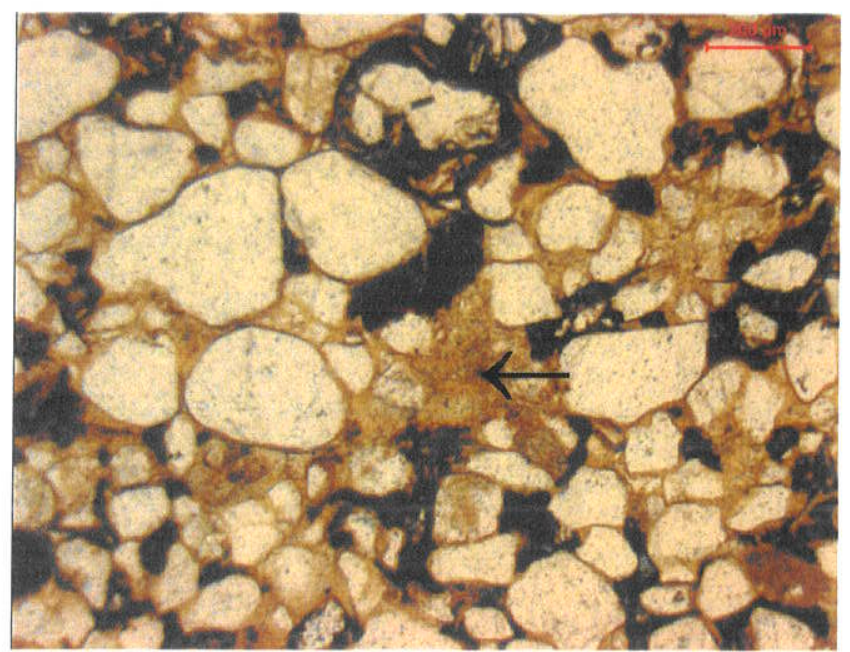

A: Matriz argilosa (seta) obliterando a porosidade primária, o betume aparece em preto. Ocorrência do Morro do Bofete.

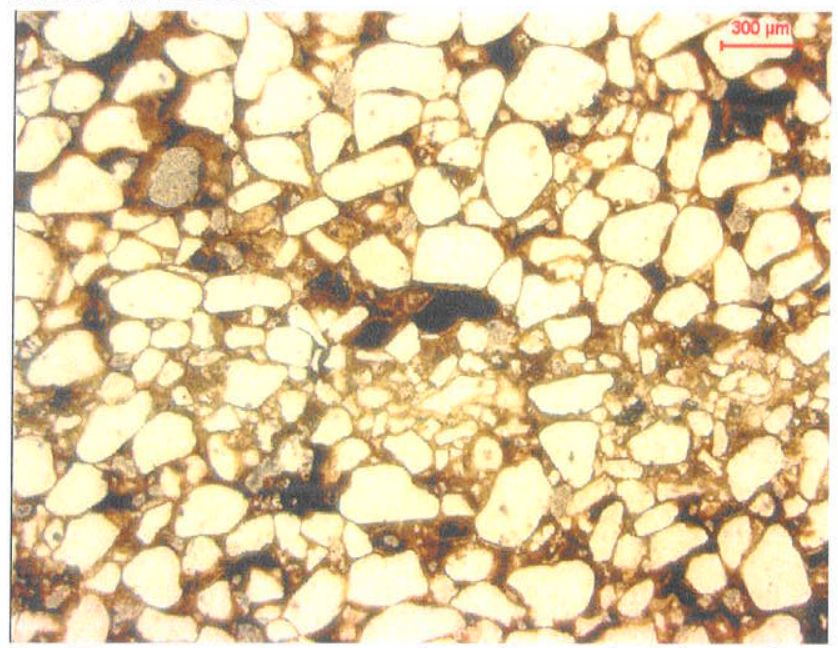

B: Presença de camadas de material argiloso (matriz) obliterando a porosidade em função de estruturas sedimentares. Ocorrência Nhaíva.

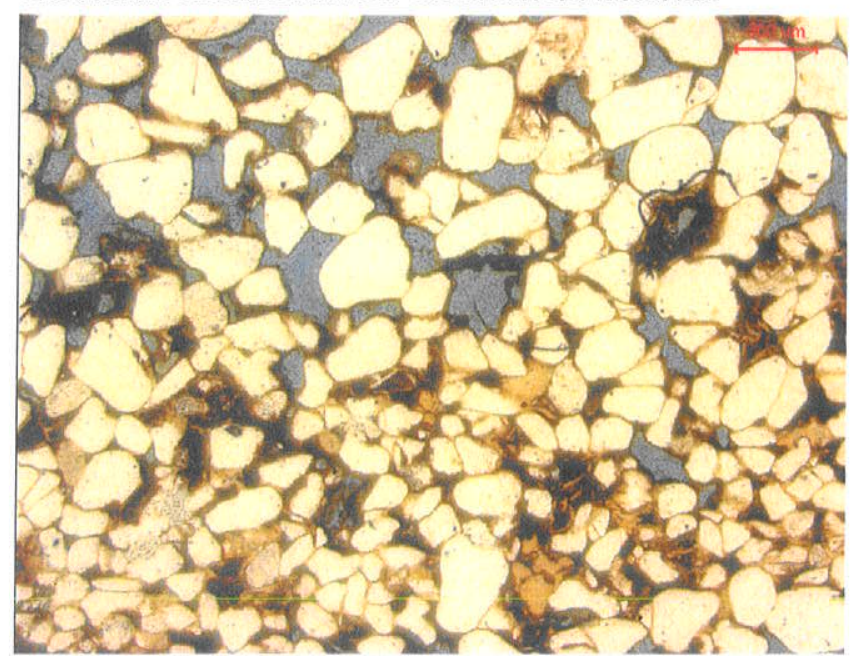

C: Variação no preenchimento de betume em função da variação de granulometria. Morro do Bofete.

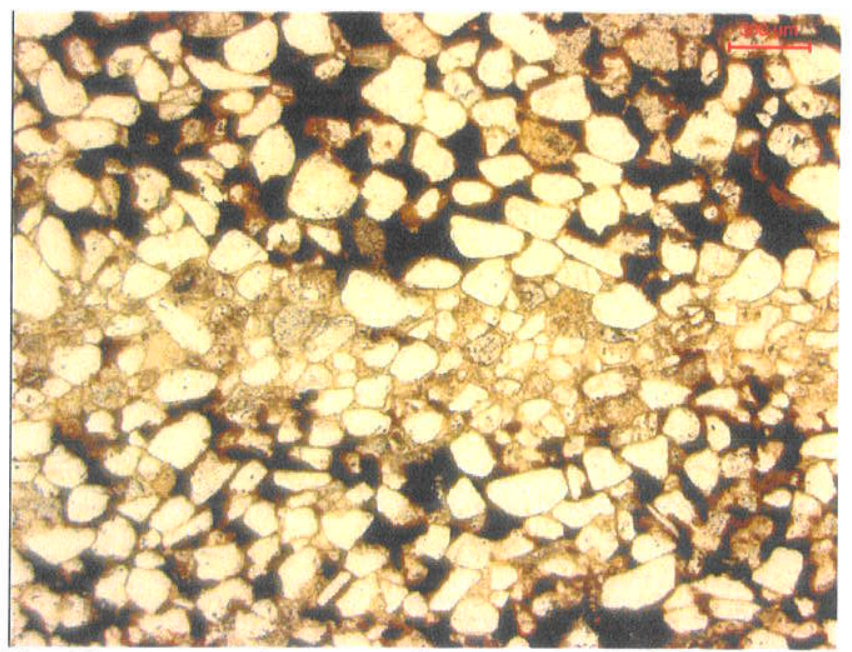

D: Presença de camadas de material argiloso (matriz) obliterando a porosidade em função de estruturas sedimentares. Ocorrência Itatigue

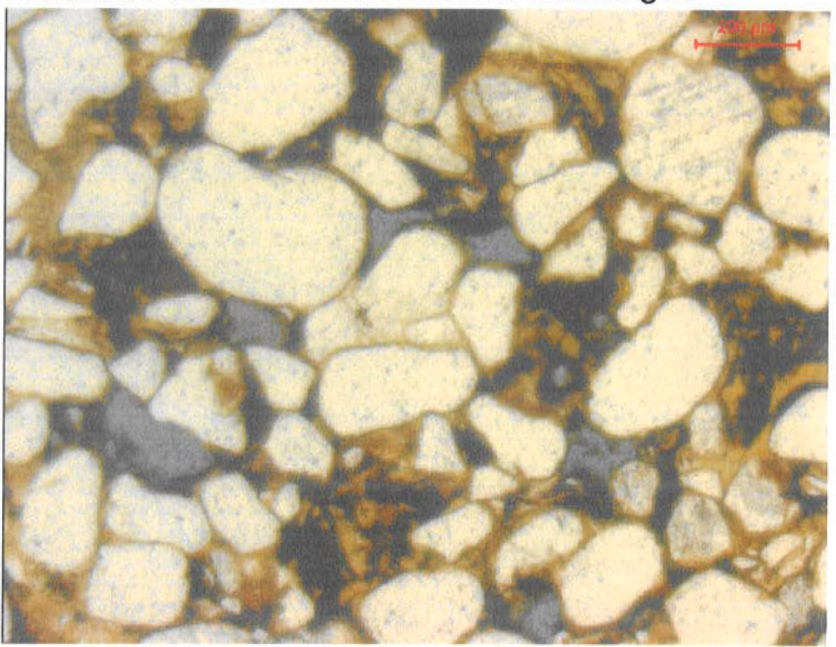

F: Presença de betume, em preto,ocupando a porosidade primária e em azul poros remanescentes sem preenchimento. Ocorrência do Morro do Bofete.

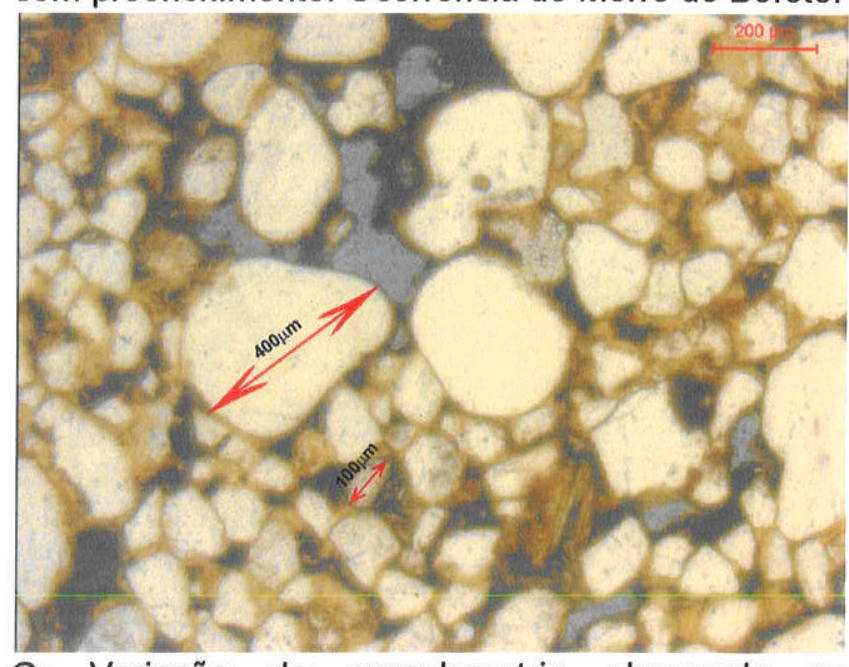

G: Variação de granulometria observada na ocorrência do Morro do Bofete.

Figura 4.2: Imagens de amostras de arenito asfáltico em lâminas delgadas. 
Em princípio conclui-se que o processo de compactação e diagênese estava mais adiantado no arenito Tatuí em relação ao arenito Pirambóia no tempo da chegada dos hidrocarbonetos na rocha reservatório. $\mathrm{O}$ arenito Tatuí já estava soterrado pelos sedimentos das Formações Teresina e Pirambóia. Já os contatos mais frouxos dos grãos de arenito da Fm. Pirambóia indicam que o processo de compactação existia mas não tinha a mesma intensidade como da Fm. Tatuí.
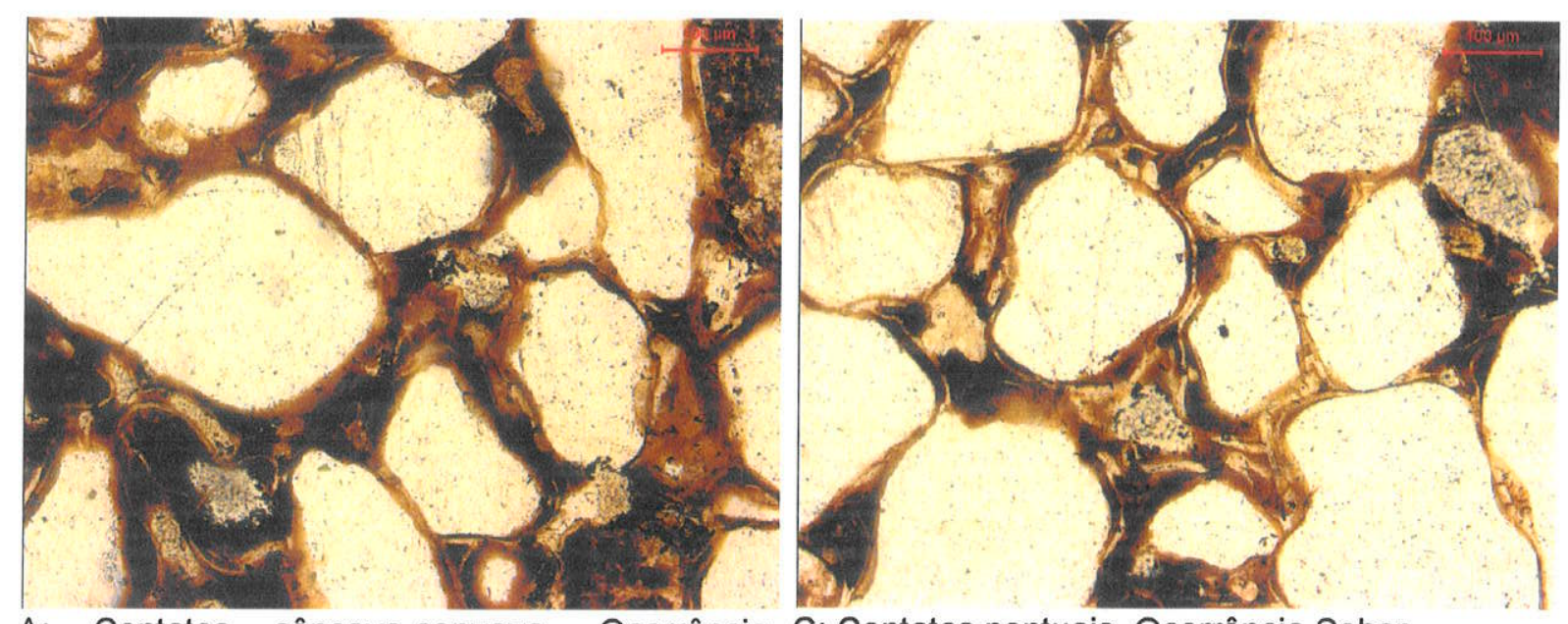

A: Contatos côncavo-convexo. Ocorrência C: Contatos pontuais. Ocorrência Sobar.

Sobar.

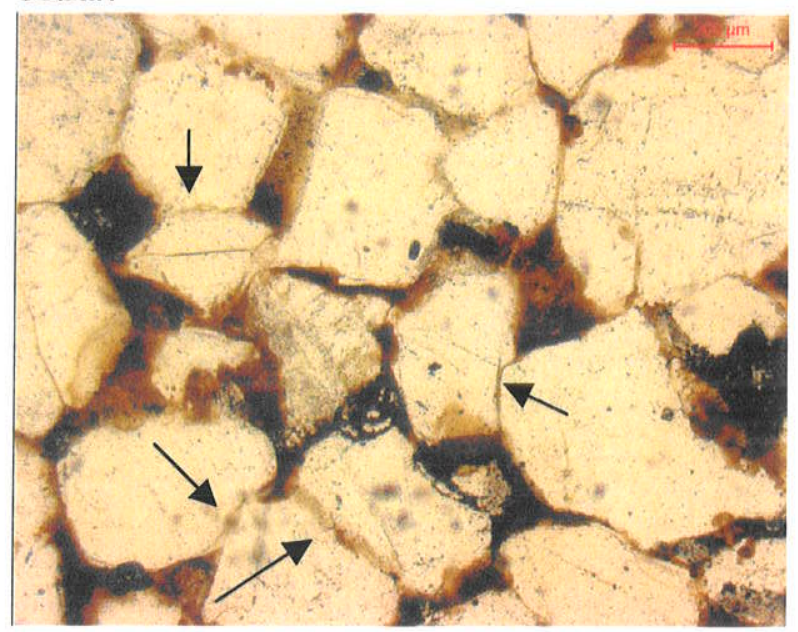

B: Contatos com grãos suturados (seta). Ocorrência de Jacutinga.

Figura 4.3:Tipo de contatos de grãos observados em lâminas delgadas, amostras de arenito asfáltico.

A Tabela 3 apresenta um resumo das observações texturais em lâmina delgada de algumas ocorrências A ausência de hidrocarbonetos nos estratos está principalmente relacionada a porções onde os poros estão preenchidos por matriz.

Experimentalmente, foi testada a determinação da porosidade de uma amostra de arenito asfáltico. O método empregado utiliza a imagem de uma amostra de arenito e determina, por classificação de imagem, a porcentagem em área de poros preenchidos por 
betume e de poros vazios. O sistema utiliza uma imagem colorida no sistema RGB em uma escala de 256 tons para cada canal (Red, Green, Blue). A definição dos elementos de interesse (poros com betume e poros vazios) é feita a partir de amostras indicadas pelo operador do sistema. Para cada amostra é reconhecido o limiar para cada canal de cores, o programa então expande a amostra para todos os elementos da imagem (pixe/s) com os mesmos limiares para cada tom. A determinação da porcentagem de área é feita a partir da contagem de pixe/s da característica de interesse sabendo-se a quantidade total de pixe/s da imagem.

Tabela 3: Observações em lâmina delgada.

\begin{tabular}{|c|c|c|c|c|c|c|c|}
\hline Lâmina & Ocorrêncla & Granul (mm) & Esferlcldade & Arredond & Seleção & Fábrica/empacotamento & Maturidade \\
\hline $\mathrm{CC}-20 \mathrm{~A}$ & M. Bofete & 0,23 & moderada & subarred. & moderado & cóncavo-convexo & imaturo \\
\hline $\mathrm{CC}-20 \mathrm{~B}$ & M. Bofete & 0,29 & moderada & subarred. & moderado & cóncavo-convexo & imaturo \\
\hline $\mathrm{CC}-21 \mathrm{~A}$ & Itatigue & 0,22 & alta & subarred. & multo bem & côncavo-convexo & maturo \\
\hline$C C-21 B$ & Itatigue & 0,25 & moderada & subarred. & bem & pontual a concav. & $\begin{array}{l}\text { c/óleo:maluro; } \\
\text { s/óleo:imaturo }\end{array}$ \\
\hline $\mathrm{CC}-22 \mathrm{~A}$ & Jacutinga & 0,42 & moderada & arredond. & muito bem & suturado & supermaturo \\
\hline $\mathrm{CC}-22 \mathrm{~B}$ & Jacutinga & 0,46 & moderada & subarred. & bem & suturado a concav. & supermaturo \\
\hline $\mathrm{CC}-23 \mathrm{~A}$ & Sobar & 0,19 & moderada a alta & arredond. & moderado & pontual a concav. & maturo \\
\hline CC-24A & Nhaiva & 0,24 & moderada a alta & subarred. & muito bem & côncavo-convexo & supermaturo \\
\hline $\mathrm{CC}-24 \mathrm{~B}$ & Nhaiva & 0,32 & moderada & subarred. & moderado a pobre & pontual & maturo \\
\hline $\mathrm{CC}-24 \mathrm{C}$ & Nhaiva & $\begin{array}{l}\text { c/óleo } 0.33 \\
\text { s/óleo: } 0.14\end{array}$ & moderada & subarred. & moderado a pobre & $\begin{array}{l}\text { pontual a concav. } e \\
\text { imbricamento }\end{array}$ & $\begin{array}{l}\text { c/óleo:maturo; } \\
\text { s/óleo:imaturo }\end{array}$ \\
\hline
\end{tabular}

Para o ensaio foi utilizada uma lâmina de arenito asfáltico do Morro do Bofete. Nesta lâmina, foram coletadas 7 imagens (amostras) com aumento de 25 vezes do microscópio óptico, luz não polarizada. As imagens (Figura 4.4) foram adquiridas por uma câmera digital Leica e processadas no softwares QWIN Leica.

O resultado (Tabela 4) demonstra um valor médio de cerca de $11 \%$ de poros preenchidos por betume e cerca de $3 \%$ de poros vazios. É interessante notar que há grande dispersão na comparação entre valores de poros preenchidos e poros vazios. Em uma das amostras a porcentagem de poros vazios é maior do que a de poros preenchidos por betume. Este fato demonstra que embora houvessem poros vazios o betume não os preencheu, provavelmente devido a sua alta viscosidade.

Tabela 4: Porosidade do arenito asfáltico medida em lâmina delgada, Morro do Bofete.

\begin{tabular}{|l|r|r|}
\cline { 2 - 3 } \multicolumn{1}{c|}{} & \multicolumn{2}{c|}{$\%$ em área } \\
\hline Amostra & \multicolumn{1}{c|}{ Betume } & Vazio \\
\hline 1 & 10,69 & 0,11 \\
\hline 2 & 8,3 & 0,79 \\
\hline 3 & 8,41 & 0,57 \\
\hline 4 & 17,7 & 0,77 \\
\hline 5 & 14,26 & 4,52 \\
\hline 6 & 7,76 & 13,45 \\
\hline 7 & 11,7 & 0,1 \\
\hline Valor médio & 11,26 & 2,90 \\
\hline
\end{tabular}


Segundo os resultados de ensaios de porosidade apresentados por Franzinelli (1972), o valor máximo de freqüência de amostras com asfalto tem valores de porosidade total que variam de 45 a 50\%. Segundo Roncaratti (1971, apud Franzinelli 1972), a porosidade efetiva no poço 9-PAA-I-SP varia de 20 a $32 \%$ aproximadamente.
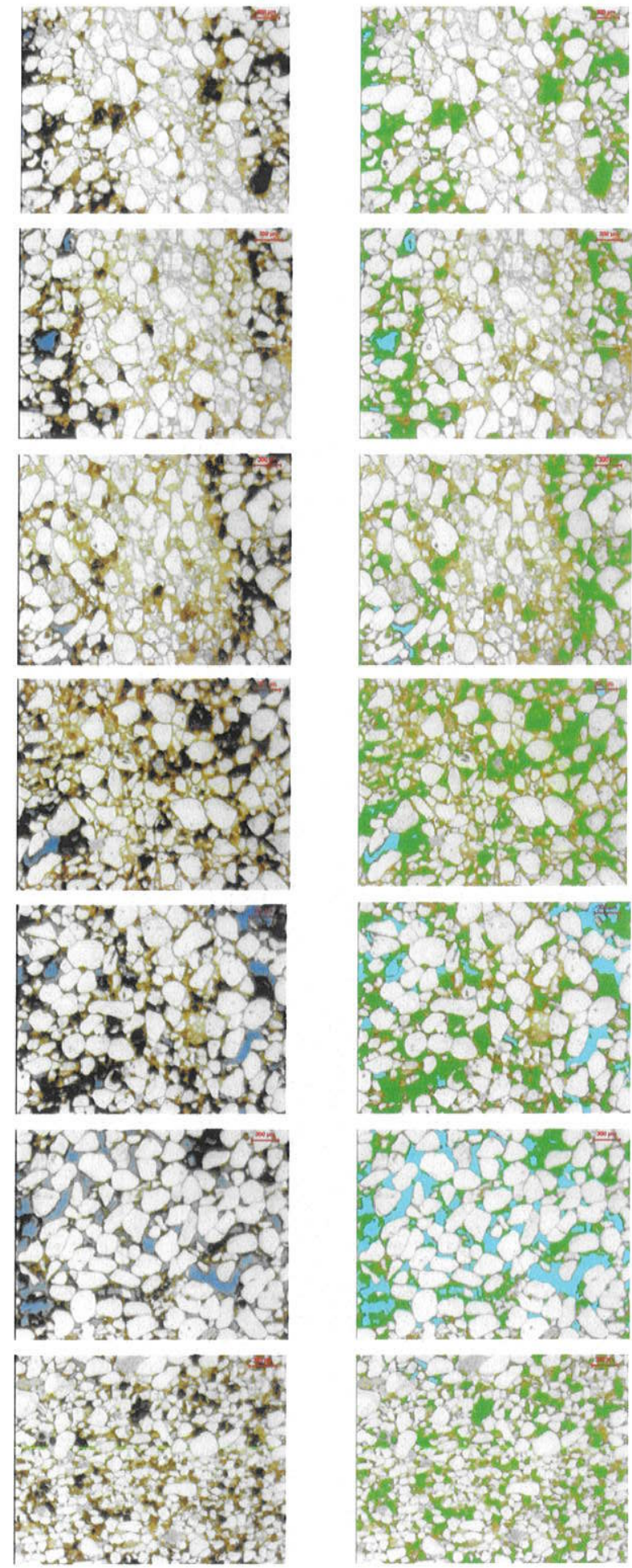

Figura 4.4: Imagens da lâmina de arenito asfáltico do Morro do Bofete utilizadas para determinação de porosidade. 


\subsubsection{Localização das ocorrências}

As ocorrências são encontradas em mais de 15 localidades no Estado de São Paulo (Figura 4.5), localizam-se ao sul do Rio Tietê e à norte do rio Paranapanema, afloram nos municípios de Angatuba, Guareí, Bofete e Anhembi (Tabela 5).

Tabela 5: Localização das ocorrências de arenitos asfálticos.

\begin{tabular}{|c|c|c|c|c|c|c|c|}
\hline Ocorrêncla & $E(m)$ & $N(m)$ & Cota & Dique assoclado & Espessura & Prof. Teresina & Prof. max. \\
\hline Jacutinga $^{1}$ & 789316 & 740606 & 660 & Não & 5 & $\cdot$ & - \\
\hline Itatigue $^{2}$ & 780238 & 7412922 & 702 & Não & 31 & 48 & 38 \\
\hline Nhaiva $^{2}$ & 786034 & 7415501 & 703 & $\operatorname{Sim}(N E)$ & 93 & 70 & 57 \\
\hline Sobar & 769878 & 7413118 & 625 & Nâo & 9 & 35 & 28 \\
\hline Sobar $\|^{2}$ & 769534 & 7414274 & 645 & Não & - & - & - \\
\hline Sobar $\mathrm{III}^{2}$ & 771234 & 7415906 & 630 & Não & - & - & r \\
\hline Bairro Quebra ${ }^{2}$ & 787292 & 7420877 & 703 & Não & - & - & - \\
\hline Fazenda São Jorge ${ }^{2}$ & 783226 & 7431789 & 569 & $\operatorname{Sim}(N E)$ & - & - & - \\
\hline Fazenda São Jorge $\|^{2}$ & 782302 & 7432310 & 536 & $\operatorname{Sim}(N E)$ & - & - & - \\
\hline Morro do Bofete ${ }^{2}$ & 783254 & 7432376 & 544 & $\operatorname{Sim}(N)$ & & 57 & \\
\hline Morro do Bofete $\|^{2}$ & 783150 & 7432514 & 553 & $\operatorname{Sim}(N E)$ & - & - & - \\
\hline Morro do Bofete $\|^{2}$ & 783412 & 7432378 & 553 & $\operatorname{Sim}(N)$ & - & - & - \\
\hline Morro do Bofete $\mathrm{IV}^{2}$ & 783450 & 7432402 & 558 & $\operatorname{Sim}(N)$ & - & - & - \\
\hline Bairro da Mina ${ }^{2}$ & 782274 & 7432619 & 543 & $\operatorname{Sim}(\mathrm{NE})$ & $\cdot$ & - & - \\
\hline Bairro da Mina $\|^{2}$ & 782259 & 7432660 & 540 & $\operatorname{Sim}(\mathrm{NE})$ & $\overline{-}$ & r & - \\
\hline Bairro da Mina \|\|$^{2}$ & 782290 & 7432636 & 539 & Sim (NE) & - & - & - \\
\hline Estrada da Mina ${ }^{2}$ & 782530 & 7432650 & 539 & $\operatorname{Sim}(\mathrm{NE})$ & - & - & $*$ \\
\hline Estrada da Mina $\|^{2}$ & 782439 & 7432752 & 551 & Sim (NE) & - & - & - \\
\hline Piapara $^{\star^{2}}$ & 783650 & 7471000 & 577 & Não & 16 & 80 & 20 \\
\hline Moquém ${ }^{2}$ & 803648 & 7478267 & 547 & $\operatorname{Sim}(\mathrm{NE})$ & - & - & - \\
\hline Moquém $\|^{2}$ & 804014 & 7478826 & 535 & $\operatorname{Sim}(\mathrm{NE})$ & - & - & $\overline{-}$ \\
\hline Betumita $^{2}$ & 806036 & 7479911 & 525 & $\operatorname{Sim}(\mathrm{NE})$ & 80 & 130 & 47 \\
\hline Fazenda Ribeiráo Claro ${ }^{2}$ & 807271 & 7483403 & 528 & Não & - & - & $*$ \\
\hline Braço da Represa ${ }^{2}$ & 787587 & 7482382 & 472 & Nāo & - & - & - \\
\hline Volta Grande ${ }^{\star^{2}}$ & 783460 & 7488200 & 455 & Não & - & - & - \\
\hline Porto Martins ${ }^{2}$ & 777619 & 7488660 & 453 & $\operatorname{sim}(N W)$ & * & - & - \\
\hline
\end{tabular}

*Ocorrências nâo visitadas; (1) Reservatório Tatứ; (2) Reservatório Pirambóia.

O acesso a algumas ocorrências é feito facilmente pela densa rede viária da região, entretanto algumas são acessiveis apenas após caminhadas. 


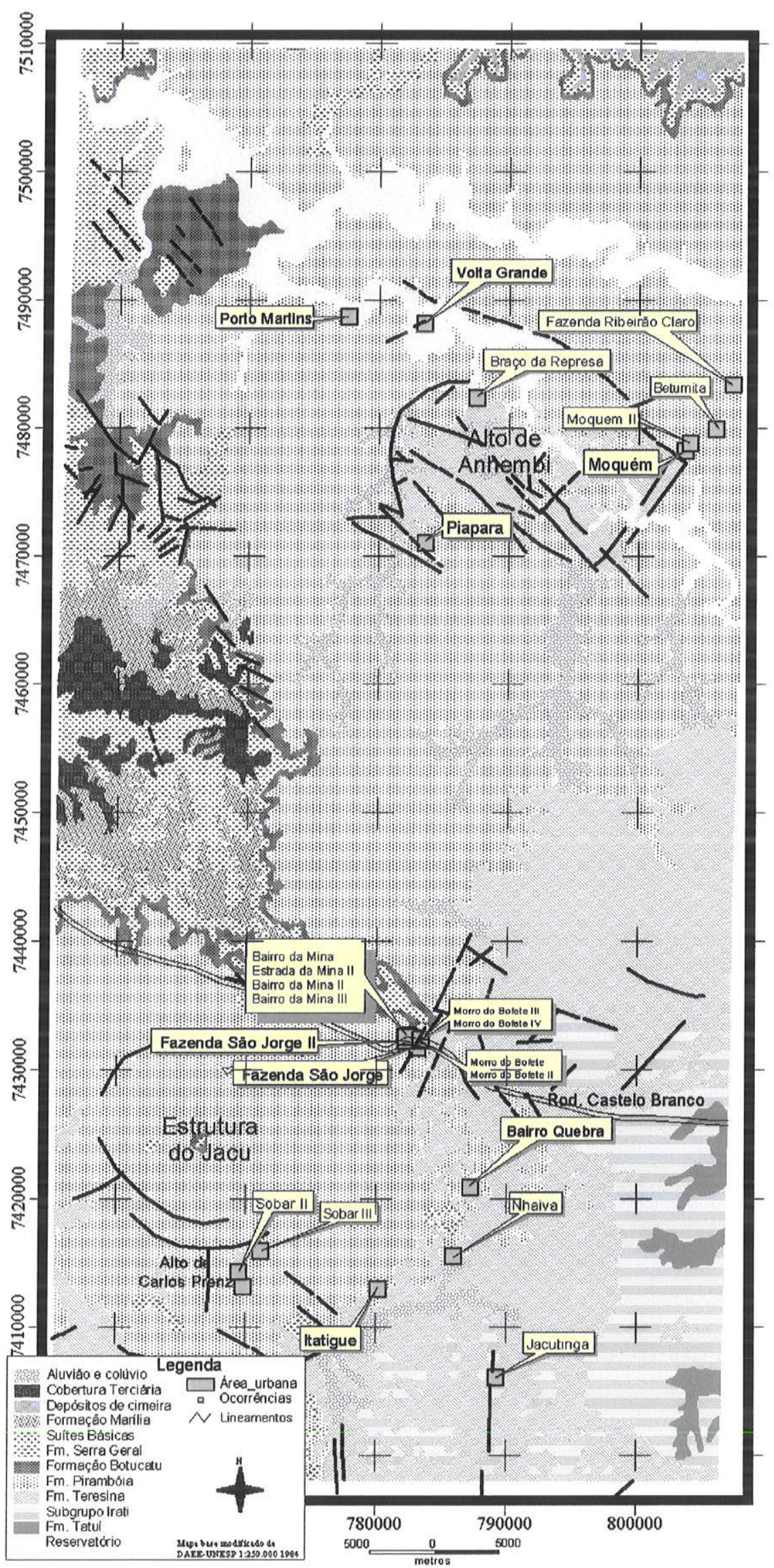

Figura 4.5: Localização das principais ocorrências e geologia da área. 
A citação de ocorrências de arenitos asfálticos é feita desde os trabalhos de prospecção mais antigos na área como Collon (1897), Washburne (1930) e Oliveira (1920); entretanto, todos carecem de uma apresentação sistemática das ocorrências incluindo sua localização, à exceção do trabalho de Franzinelli (1972). Essa autora apresenta um estudo das ocorrências de arenitos asfálticos no Estado de São Paulo, incluindo descrição dos afloramentos de arenitos asfálticos no Estado de São Paulo e mapa de localização na escala 1:100.000.

A área está completamente inserida na Bacia do Paraná, em sua borda leste, na Depressão Periférica. De modo geral, a topografia é pouco acidentada, contudo há áreas de escarpa com desniveis de até $300 \mathrm{~m}$ como na Serra de Botucatu. A área é coberta por uma rede de drenagem estruturada e relacionada a condicionantes geológicos. Em relação à cidade de Botucatu, as ocorrências à nordeste estão próximas da calha do Rio Tietê, já as ocorrências da porção sul estão na região da Serra de Angatuba. A Figura 4.6 apresenta em detalhe a localização das principais ocorrências de arenitos asfálticos.

Distinguem-se duas regiões principais de ocorrências de arenitos asfálticos na borda leste da Bacia do Paraná. Uma região ao norte da cuesta de Botucatu (Planalto Residual de Botucatu) chamada área Anhembi ou Alto de Anhembi localizada na depressão do Rio Tietê, nas cercanias da cidade de Anhembi, junto à represa de Barra Bonita, Rio Tietê.

A outra região localiza-se à sul do Planalto de Botucatu, na região denominada área Jacu ou área da estrutura do Jacu. Esta área localiza-se na depressão do Rio Paranapanema com ocorrências nas cercanias da cidades de Guareí, Angatuba e junto à Rodovia Castelo Branco no município de Bofete.

Um elemento importante na área do Jacu é a presença de altos estruturais com afloramento em rochas permianas em meio a rochas triássicas. Estas estruturas estão provavelmente relacionadas a zonas de fraqueza como falhamentos regionais. $A$ estrutura geológica mais proeminente é o Alto Estrutural de Sobar também chamado de Domo de Carlota Prenz, que ocorre na porção sul da estrutura do Jacu (Figura 4.5). A estrutura do Jacu é uma morfoestrutura com um padrão anelar de drenagem e diâmetro de $20 \mathrm{~km}$ (rios Santo Inácio e Capivari) e com padrão radial externo de drenagem (Rio Antônio José e Ribeirão da Restinga).

A área do Alto de Anhembi é caracterizada também pelo afloramento de rochas Permianas em meio a rochas triássicas. Há uma forte estruturação de direção NW com estruturas NE menos freqüentes. A região ao noroeste da cidade de Anhembi é caracterizada por uma expressiva anomalia de drenagem na forma de semi-circunferência formada pelo Rio Alambari e por um braço da Represa de Barra Bonita, nesta anomalia de drenagem também são observadas drenagens radiais como o Ribeirão Água do Monjolo e Córrego Barreirinho. 

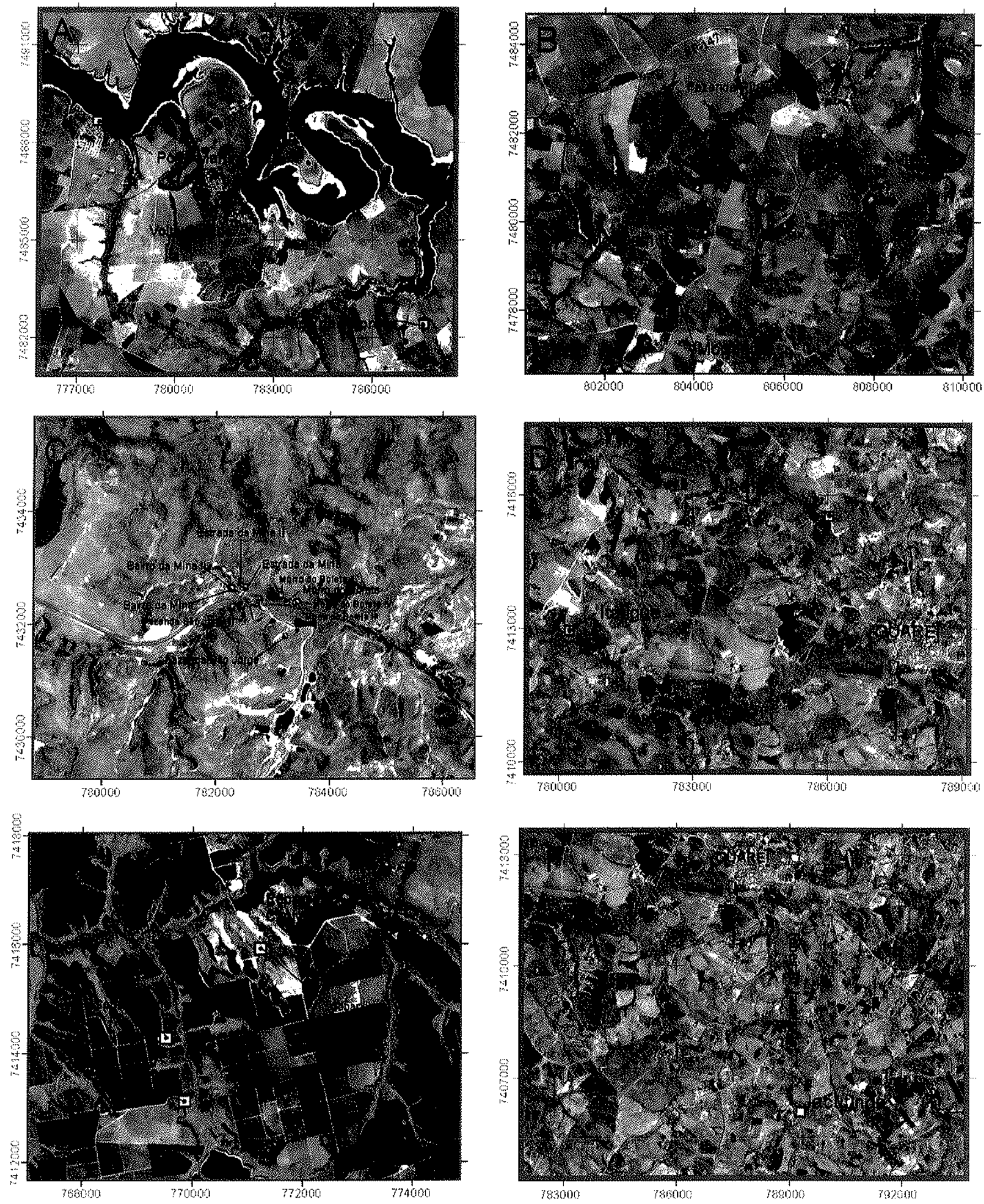

Figura 4.6: Detalhe da localização das principais ocorrências de arenitos asfálticos. (A) Porto Martins \& Volta Grande; (B) Betumita \& Moquém; (C) Morro do Bofete; (D) Nhaíva \& Itatigue; (E) Sobar; (F) Jacutinga. Imagem Landsat 7 ETM+ banda pancromática de 29 de novembro de 1999. 


\subsubsection{Porto Martins \& Volta Grande}

A ocorrência de Porto Martins localiza-se às margens da Represa de Barra Bonita, no Rio Tietê (Figura 4.6A). O acesso dá-se pela estrada Botucatu - Santa Maria da Serra (Rodovia Geraldo de Barros). A ocorrência de Volta Grande localiza-se também em barranco nas margens da represa de Barra Bonita, sendo acessivel somente por via fluvial.

$O$ arenito asfáltico aflora em um barranco da represa, cota $453 \mathrm{~m}$, nas proximidades da Vila de Porto Martins. Em função do nível do reservatório, parte do afloramento fica submerso. $O$ afloramento tem um comprimento de aproximadamente $200 \mathrm{~m}$ e uma espessura aparente de $8 \mathrm{~m}$. A cerca de 20 metros à leste do principal afloramento da ocorrência de Porto Martins aflora um dique de diabásio de direção NW. Entretanto, junto ao dique o arenito asfáltico aflora em apenas um de seus lados.

O betume está impregnado em arenitos da Formação Pirambóia com estratificações cruzadas de grande porte, granulometria média a grossa e grãos bem selecionados.

Topograficamente acima do arenito asfáltico, aflora um nível de conglomerado de matriz arenosa com seixos subarredondados, subangulosos de provável origem fluvial. A maior parte dos seixos ( $80 \%)$ é composta por quartzito, as dimensões variam entre 0,5 e 5 $\mathrm{cm}$, o restante é composto por siltitos e arenitos. A matriz varia de areia fina a grossa com presença de grânulos milimétricos mal selecionados, angulosos de quartzo. Aparentemente o conglomerado tem uma deposição recente em relação aos arenitos acumuladores, em princípio atribui-se esta lente conglomerática ao processo de deposição da Formação Rio Claro (Terciário-Quaternário).

\subsubsection{Betumita, Moquém e Moquém II}

A ocorrência Betumita localiza-se no sítio Agostinho Gonçalves (desmembramento da antiga Fazenda Moquém), em um afluente da margem esquerda do Ribeirão dos Pintos no município de Anhembi (Figura 4.6B). A ocorrência situa-se na cota $550 \mathrm{~m}$. Próximo desta ocorrência, o arenito asfáltico aflora em dois afloramentos menores: Moquém e Moquém II. A ocorrência Betumita é a mais expressiva da área de estudo. Thomaz Filho (1982) apresenta um volume cubado de aproximadamente 5.712 .000 barris de óleo.

O betume está impregnado em arenitos da Formação Pirambóia, que apresentam estratificações cruzadas de porte métrico (Figura 4.7). Verificam-se porções decamétricas de arenitos asfálticos maciços intercalados com arenitos asfálticos listrados. Steveaux et al. (1980) apresentam uma descrição da frente de lavra de 150 metros de comprimento e 20 metros de espessura, contendo 2 maciços (homogêneos) de arenitos asfáltico intercalados com bancos de arenitos estriados e estéreis. De acordo com o relatório, a parte inferior desta unidade inicia-se por um banco de arenito homogêneo, bem preenchido, apresentando estratificação plano-paralela e cruzada de pequeno porte, passando para uma seqüência 
formada por arenito síltico branco amarelado, apresentando uma diminuição do grau de saturação de óleo em direção ao topo até tornar-se completamente estéril. Ainda de acordo com Steveaux et al. (1980), sobrepõe-se a esta seqüência basal, um banco de arenito asfáltico, homogêneo, compacto, com espessura máxima de 5 metros apresentando contato brusco na porção superior com o arenito laminado estéril, exibindo estrutura plano-paralela. Estes bancos de arenitos impregnados, não apresentam continuidade física lateral o que dificulta sua avaliação. Finalmente, no topo da seqüência, tem-se um capeamento arenoargiloso de cor cinza escuro, com uma espessura variando de 1 a 4 metros.

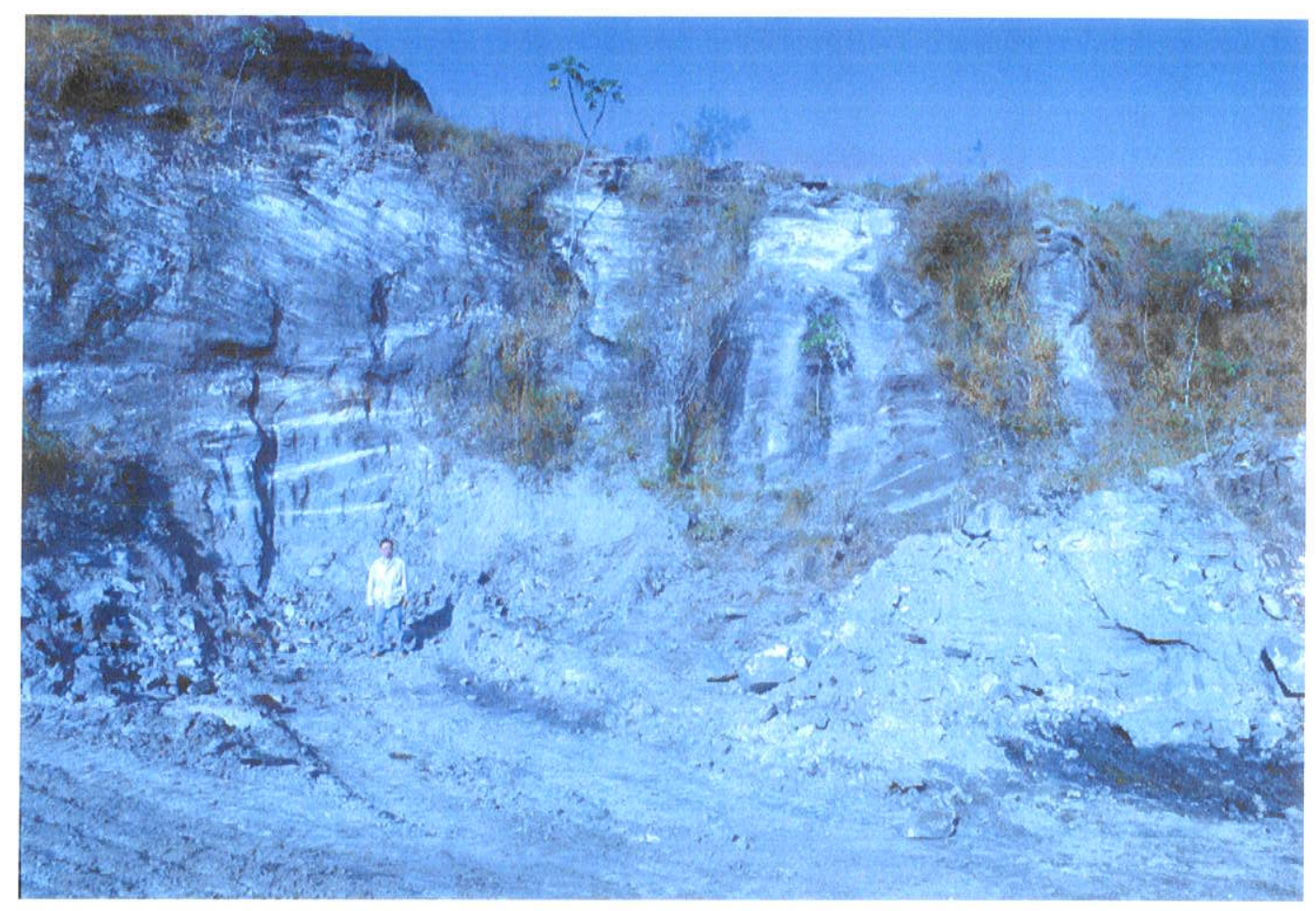

Figura 4.7: Lavra abandonada na ocorrência Betumita. Observa-se estratificações cruzadas de grande porte preenchidas por hidrocarbonetos.

Segundo Steveaux et al. (1980), a Petrobrás realizou furo de sondagem 9-PAA - 13 $\mathrm{SP}$, próximo a Betumita, detectando presença de óleo no intervalo de 15 a 47,50 metros de profundidade. A sondagem alcançou o topo da Formação Teresina aos 130 metros de profundidade.

A ocorrência localiza-se no flanco nordeste do Alto de Anhembi (foi interpretado em imagem Landsat 7 ETM+ um lineamento a leste da ocorrência). O Alto de Anhembi encontrase a oeste desta ocorrência, o contato da Fm. Teresina com a Formação Pirambóia aflora a alguns quilômetros da ocorrência (aproximadamente $5 \mathrm{~km}$ ). Thomaz Filho (1982) cita a descoberta de um dique de diabásio não aflorante a partir de campanha de sondagem da 
Petrobrás na área de ocorrência. O autor observa que o dique agiu como barreira a migração lateral do óleo e como caminho de migração vertical.

Segundo informações do sitiante Agostinho Gonçalves, superficiário, a exploração da Mina Betumita ocorreu a partir da metade da década de 1930 até aproximadamente 1954. Havia uma estrutura mineira montada no local incluindo 2 britadores à vapor, o minério era utilizado basicamente para pavimentação. A Figura 4.8 é uma gravura (autor desconhecido) na qual observam-se as instalações dos britadores e escritórios da mina. Esta gravura foi encontrada na casa do sitiante Agostinho Gonçalves.

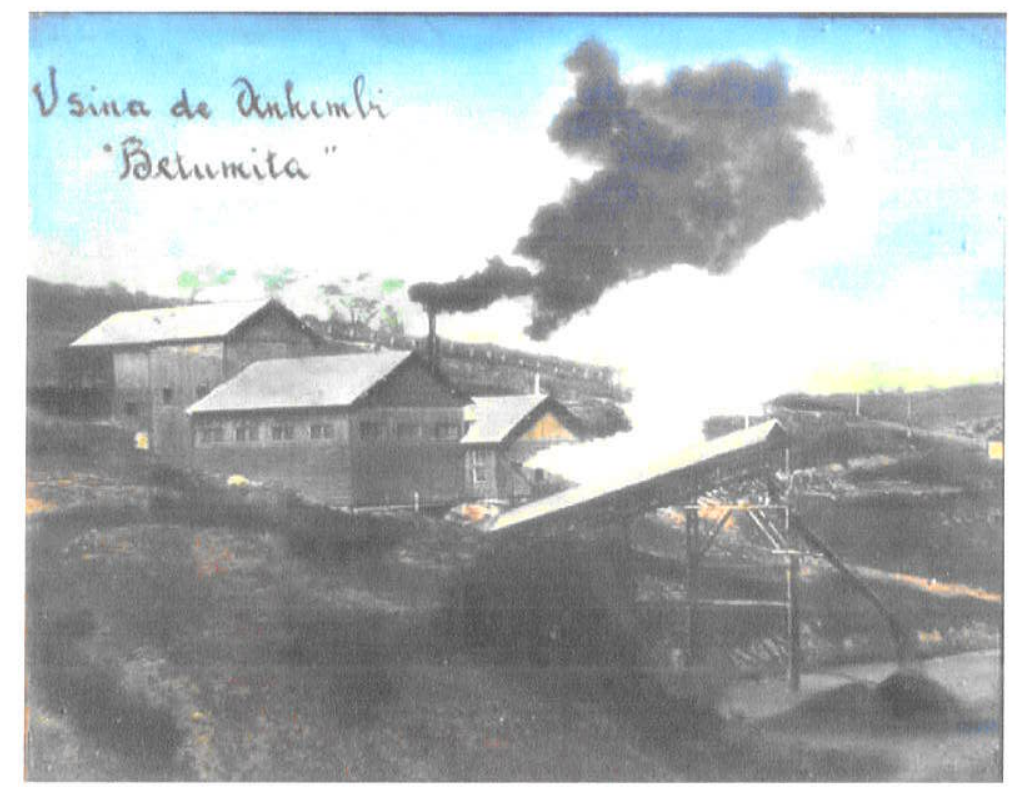

Figura 4.8: Instalações de britagem do arenito asfáltico da mina Betumita.

A ocorrência Moquém localiza-se no Sítio Moquém (desmembramento da antiga Fazenda Moquém), a cerca de $2 \mathrm{~km}$ a oeste da ocorrência Betumita, na cabeceira do córrego Moquém, próximo ao Morro Amarelo, em um afluente de sua margem esquerda. A ocorrência localiza-se em um pasto no alto de um morro, na cota $550 \mathrm{~m}$.

A ocorrência é composta por arenitos da Formação Pirambóia de granulometria média de cor cinza escuro com porções homogêneas e porções listradas, esta ocorrência tem uma espessura aflorante de aproximadamente 5 a 6 metros. É interessante observar a presença de cupinzeiros de cor cinza escuro e textura semelhante ao arenito asfáltico que auxiliam a mapear a distribuição espacial da ocorrência, fora da área de ocorrência do arenito asfáltico os cupinzeiros têm cores que variam do vermelho ao amarelo.

Em algumas porções da área de ocorrência, nota-se a presença de solo avermelhado escuro. Além disso, foram encontrados clastos de arenito com cimentação ferruginosa, estes clastos, aliados à ocorrência de solo avermelhado, podem ser indícios da presença de rochas 
básicas em subsuperfície ou aflorantes na área. Levantamento magnetométrico de campo confirma esta sugestão. A partir dos dados aeromagnéticos, pode-se observar que a ocorrência Moquém encontra-se junto a um alto magnético que é outra evidência de corpos básicos na área da ocorrência. A partir da imagem Landsat 7 ETM+ foi interpretado um lineamento de direção NW junto a ocorrência, também há uma alinhamento de altos magnéticos na mesma direção e posição deste lineamento interpretado.

A proximidade e características dos afloramentos sugerem continuidade genética entre as ocorrências Betumita e Moquém, o que demonstra a grande extensão espacial da ocorrência de arenito asfáltico, caso não houvesse erosão que provavelmente destruiu a continuidade física da ocorrência como um único elemento.

\subsubsection{Morro do Bofete, Fazenda São Jorge, Bairro da Mina e Estrada da Mina}

Estas ocorrências estão dentro de uma área de cerca de $1.500 .000 \mathrm{~m}^{2}$. As cotas topográficas das ocorrências variam de 540 até $570 \mathrm{~m}$. Devido à proximidade e distribuição espacial destas ocorrências, supõem-se sua continuidade lateral. Dessa forma, pode-se tratar de um único grande volume impregnado e posteriormente dissecado. A Figura 4.9 é um esboço geológico do entorno das ocorrências na área do Morro do Bofete. Esta área tem uma forte estruturação com lineamentos NE e NW. 


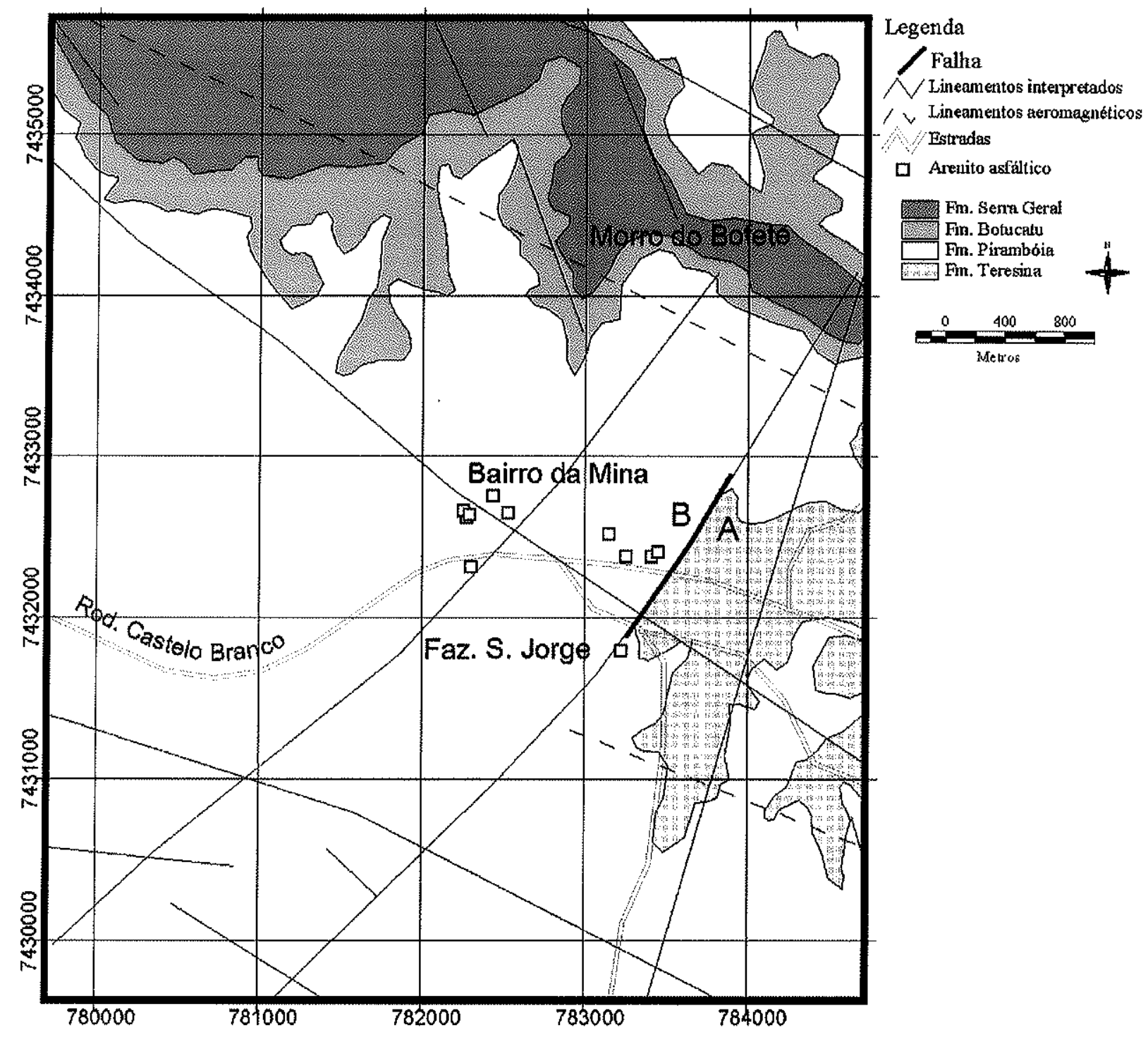

Figura 4.9: Esboço geológico das ocorrências do Morro do Bofete.

$\mathrm{Na}$ área de afloramento destas ocorrências há presença do sistema linear Torre de Pedra - Guareí (Steveaux et al., 1980), cuja direção principal é aproximadamente N20-30E. A partir de dados aeromagnetométricos interpreta-se um alto magnético de direção N50W junto a área, este alto está relacionado às rochas básicas aflorantes no Morro do Bofete, intrusões não aflorantes e falhas.

O afloramento do Morro do Bofete tem um nítido padrão de fraturamento (Figura 4.10A), também encontrado nas ocorrências do Bairro da Mina. Este fraturamento tem direção N30W, é freqüente a presença de bandas de deformação de direção N10-30E de comprimentos métrico e largura milimétrica. $\mathrm{Na}$ Figura 4.10B há bandas de deformação onde desenvolvem-se fraturas. É importante observar que as bandas de deformação não são preenchidas por óleo (Figura $4.10 \mathrm{C}$ ), estas estruturas foram geradas em eventos tectônicos 
pré migração secundária. A direção N10-30E das bandas de deformação provavelmente estão relacionadas à reativação de estruturas do embasamento.
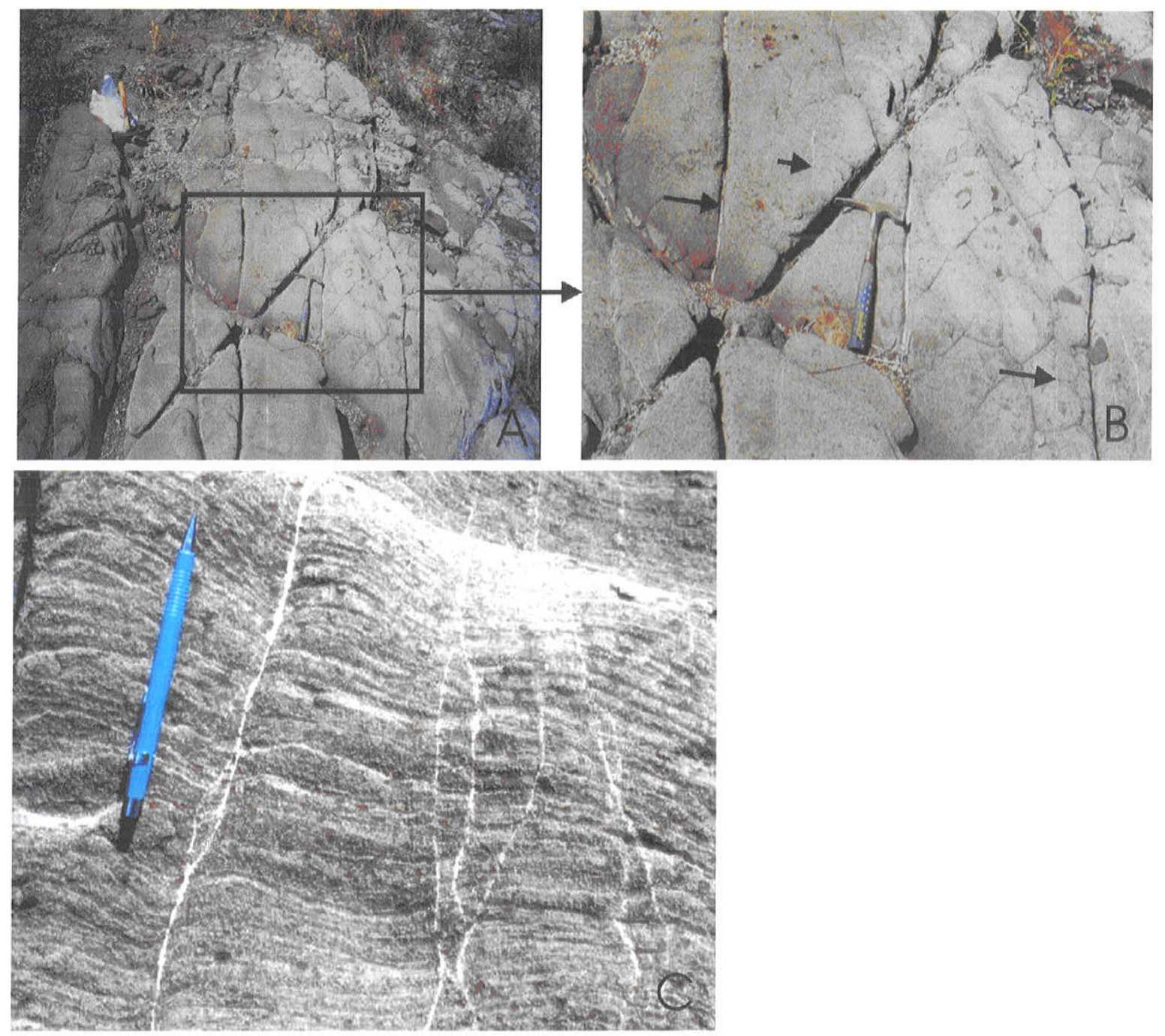

Figura 4.10: Fraturamento na ocorrência Morro do Bofete. (A) Padrão de fraturamento NW/NE. (B) Detalhe de fraturas geradas a partir de bandas de deformação, indicadas pelas setas. (C) Bandas de deformação não preenchidas por hidrocarbonetos.

Em todas estas ocorrências o betume encontra-se em arenitos da Formação Pirambóia que apresentam granulometria média e estratificações cruzadas de médio e grande portes, além de estratificações plano-paralelas. O contato da Fm. Pirambóia com a Fm. Teresina ocorre a cerca de 100 m NE da ocorrência da Fazenda São Jorge e está na cota topográfica de $540 \mathrm{~m}$. As ocorrências do Morro do Bofete, Bairro da Mina e Faz. São Jorge estão localizadas em blocos baixos de falhas (Figura 4.11). Estas falhas têm direções aproximadas NE e NW e foram intrudidas por rochas vulcânicas. 


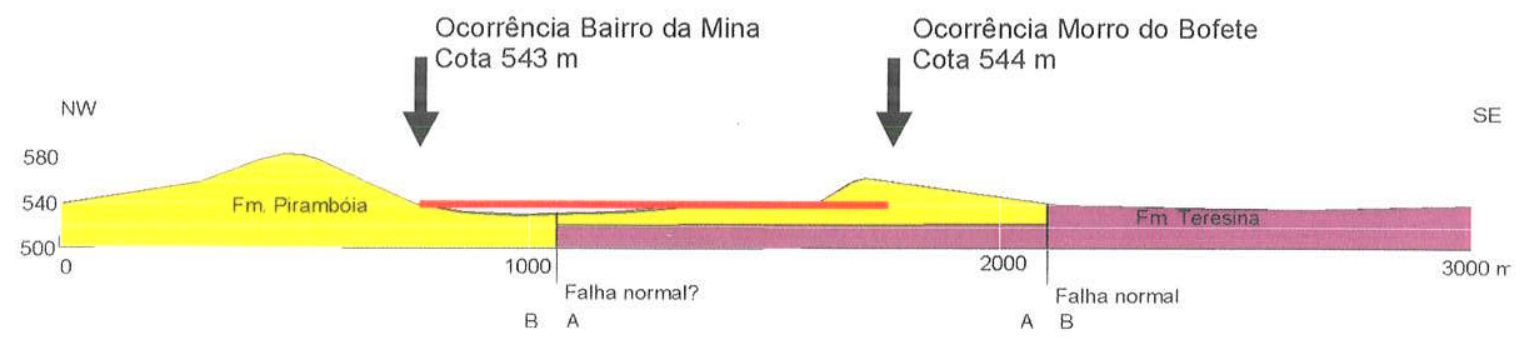

Figura 4.11: Perfil geológico esquemático na área do Morro do Bofete.

\subsubsection{Itatigue ou Guareí I}

A ocorrência de Itatigue localiza-se no município de Guareí, bairro de Capela Velha, próximo à capela Nossa Senhora Aparecida (Figura 4.6D). A ocorrência está situada na cota 710 m. Durante a década de 40 foi explorada pela Companhia Itatigue S.A., para produção de gasolina a partir do arenito asfáltico (CNP, 1944).

De acordo com Steveaux et al. (1980), a ocorrência Itatigue localiza-se próximo a um homoclinal, condicionada por falhas e diques de diabásio. Franzinelli (1972) citou a ocorrência posicionada na borda de um bloco levantado, onde a Formação Teresina estaria aflorando no vale próximo à área de ocorrência. O esboço geológico (Figura 4.12), mostra o contato da Formação Teresina com a Formação Pirambóia a poucos metros da área da ocorrência. Neste esboço pode-se observar lineamentos NE e NW na área de afloramento dos arenitos asfálticos. Os lineamentos aeromagnéticos na área são essencialmente de direção NE.

A interpretação de imagens de sensoriamento remoto (ETM+ Landsat 7) demonstra a presença de um lineamento de direção NW que passa junto ao vale, onde localiza-se a ocorrência de Itatigue (Figura 4.12), e um lineamento NE à leste da ocorrência. A partir dos dados aerogeofísicos, pode-se observar a presença de um expressivo alto magnético ao norte da ocorrência que evidencia a presença de um corpo de rocha básica em subsuperfície. Este corpo de dimensões quilométricas é aflorante a aproximadamente $5 \mathrm{~km}$ a nordeste da ocorrência

O Arenito Asfáltico ocorre, na Formação Pirambóia, em arenitos de granulação média a grossa, grãos foscos bem arredondados e bem selecionados, com estratificações cruzadas métricas, pouco fraturado e bastante coeso (Figura 4.13). Na porção superior do afloramento, o arenito asfáltico é homogêneo; na base do afloramento, há forte listramento (camadas alternadas com e sem betume). Em campo, notaram-se camadas sem asfalto onde a areia é fina, já nas camadas com asfalto a areia é de granulometria média a grossa. 


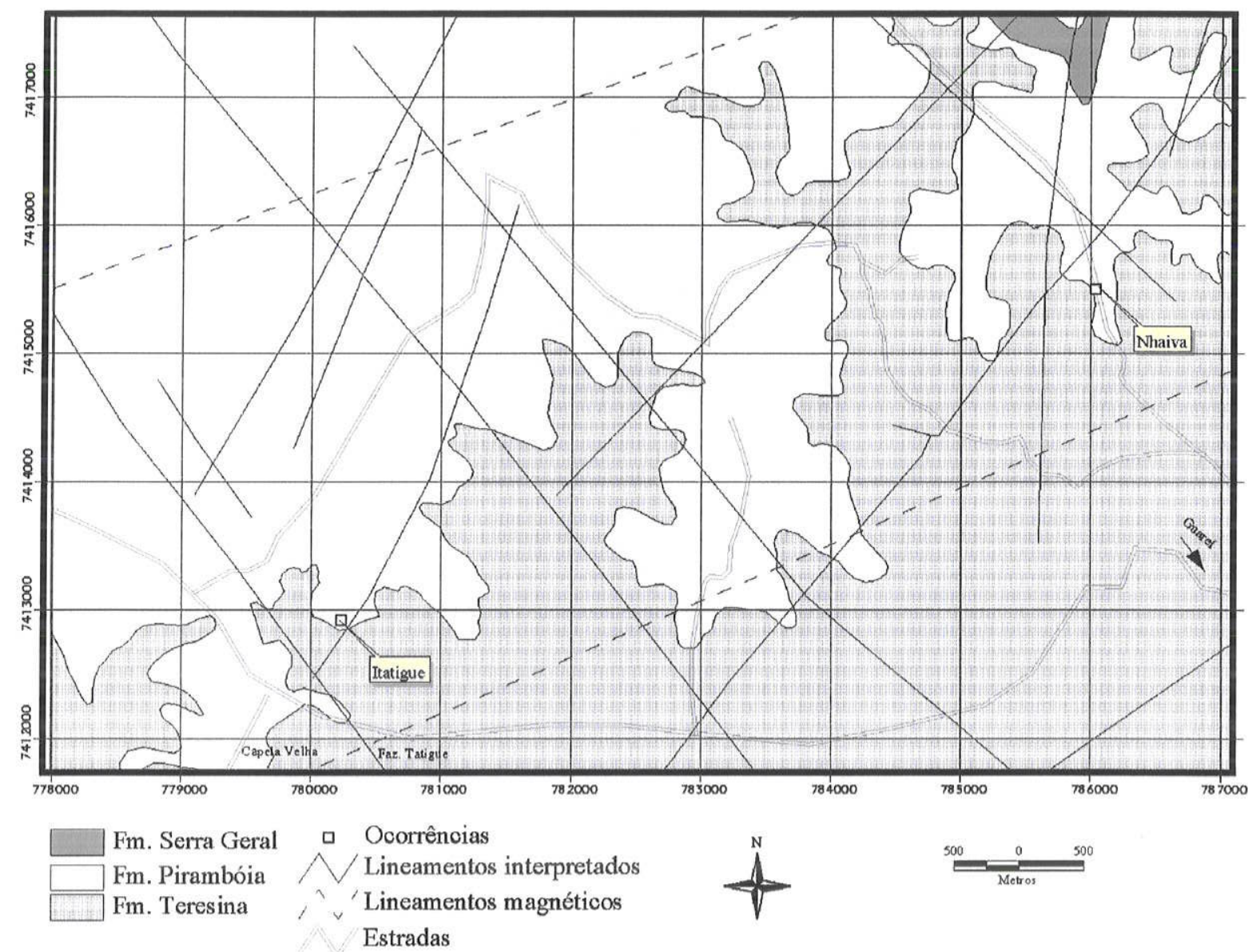

Figura 4.12: Esboço geológico das ocorrências de Itatigue e Nhaiva.

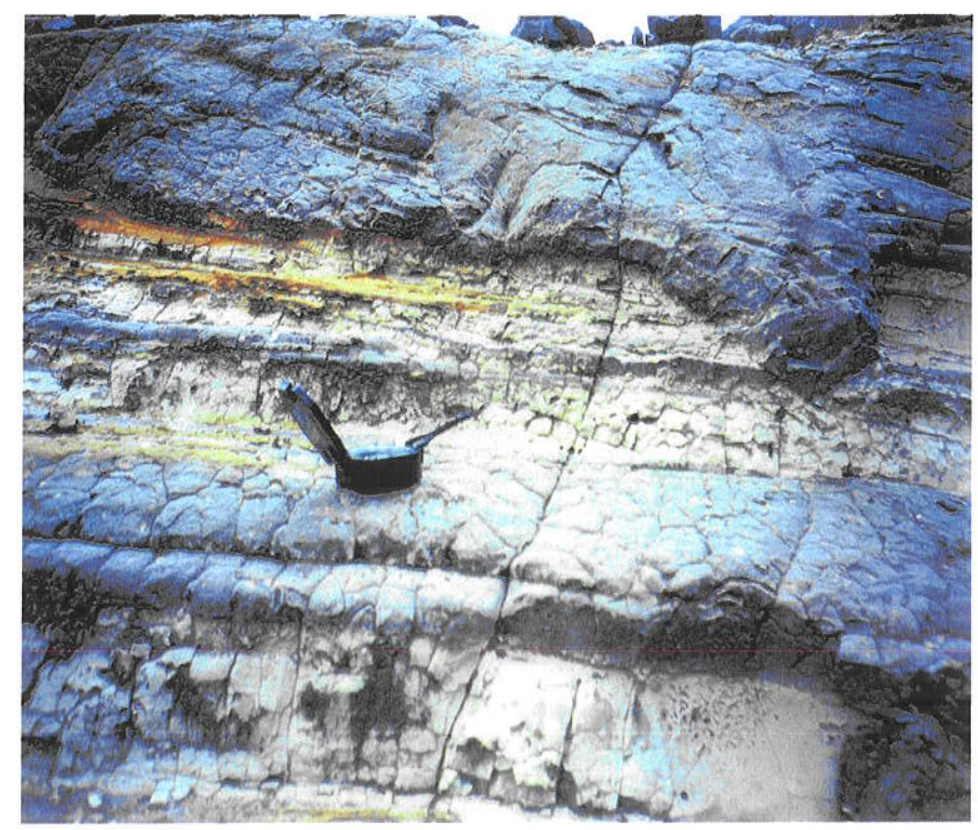

Figura 4.13: Aspecto da ocorrência Itatigue. Alternância do preenchimento por hidrocarbonetos em camadas eólicas e de interdunas. 
4.1.7 Nhaíva ou Itatigue II ou Guareí II

A ocorrência de Nhaíva localiza-se à noroeste da cidade de Guareí, próximo ao Sítio da Jazida II (Figura 4.6D). A ocorrência está na cota $700 \mathrm{~m}$ em um terreno bastante íngreme, no fundo do vale corre o Ribeirão da Areia Branca.

Foi interpretado um lineamento estrutural NW e um NE junto à ocorrência (ETM+ Landsat 7), os quais não foram reconhecidos em campo (Figura 4.13). Nos dados aeromagnéticos é possível observar a forte anomalia magnética, próxima à ocorrência, causada por corpos básicos aflorantes nas imediações e prováveis corpos básicos em subsuperfície.

A Formação Teresina aflora a poucos metros abaixo da ocorrência (15 m), o contato da Formação Teresina com a Formação Pirambóia ocorre na cota $685 \mathrm{~m}$.

Verificam-se condições geológicas muito parecidas entre a ocorrência de Itatigue e a ocorrência Nhaíva. Steveaux et al. (1980) sugerem que esta ocorrência seja um prolongamento lateral da ocorrência Itatigue.

O afloramento de arenito asfáltico apresenta betume impregnado em arenito estratificado da Formação Pirambóia. Ocorrem estratificações cruzadas de médio a grande porte (Figura 4.14). Nas estratificações cruzadas, o arenito asfáltico tem aspecto listrado devido à matriz argilosa que impediu o preenchimento completo dos poros pelos hidrocarbonetos.

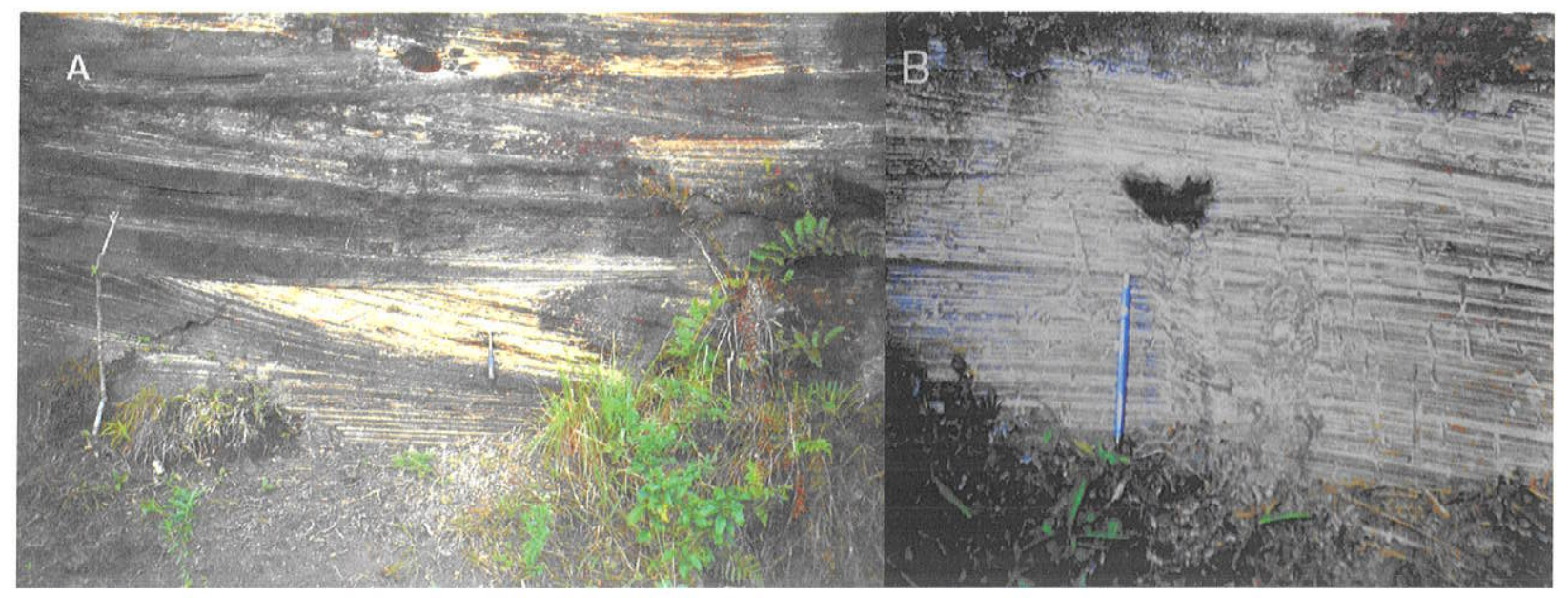

Figura 4.14: Aspecto do arenito asfáltico, ocorrência Nhaíva. (A) Estratificações cruzadas preenchidas por óleo, aspecto listrado. (B) Peturbação das estratificações, evidenciada pelo preechimento por hidrocarbonetos, na forma de canais centimétricos.

Os arenitos asfálticos também apresentam-se com pequenas pintas (centimétricas) não preenchidas, além de canais, geralmente verticais, também não preenchidos. Em ambas feições há presença de matriz que oblitera os poros.

Entre os aspectos condicionantes presentes em ambas ocorrências, destacam-se: 
- proximidade de um alto magnético;

- proximidade do contato Pirambóia/Teresina (aproximadamente 15 acima do contato), ou seja, próximo à base da Formação Pirambóia;

- presença de lineamentos (falhamentos/basculamentos) nas proximidades;

- alojamento do betume em fácies eólica da Formação Pirambóia.

\subsubsection{Sobar ou Carlota Prenz}

A ocorrência da Fazenda Sobar localiza-se ao norte da cidade de Angatuba, a sudoeste da Represa Capivari, em um afluente da margem esquerda do Rio Capivari chamado Ribeirão do Sargento, na divisa dos municípios de Guareí e Angatuba (Figura 4.6E).

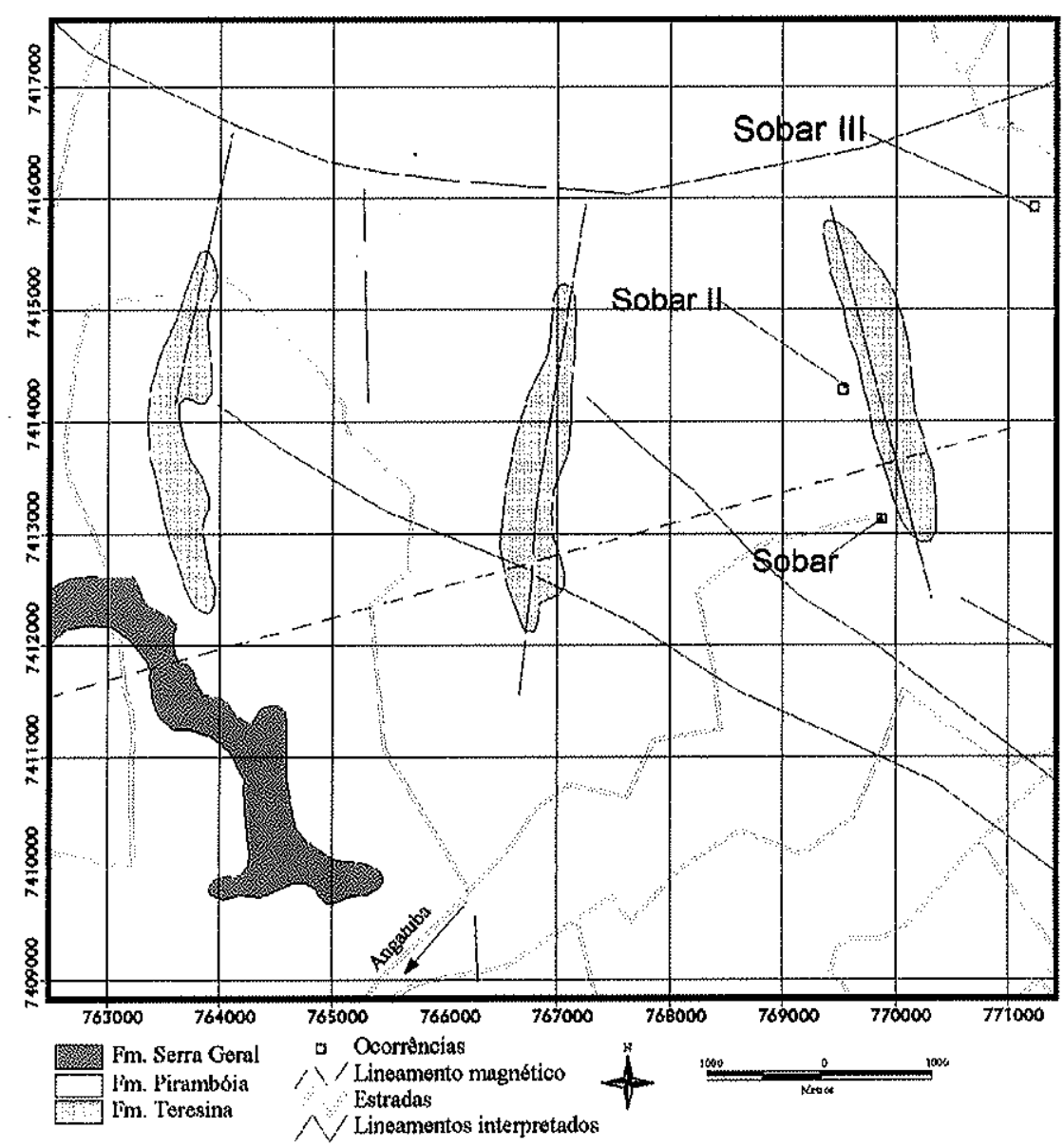

Figura 4.15: Esboço geológico da ocorrência do Sobar. As ocorrências localizam-se próximo à área de afloramento da Fm. Teresina, na região do Domo de Carlota Prenz.

Na Figura 4.15 há três ocorrências próximas ao afloramento da Fm. Teresina. Nesta região aflora a estrutura dômica de Carlota Prenz. As três ocorrências estão relacionadas a lineamentos NS localizados no flanco sul da estrutura do Jacu. Um importante lineamento 
aeromagnético NE corta a área de afloramento dos arenitos asfálticos. Este lineamento está relacionado à Soleira de Angatuba (Fúlfaro, 1967) que aflora na região.

Em campo, foram encontrados três pontos distintos de afloramento de arenitos asfálticos, não se pode observar se há continuidade de acumulação entre os pontos (Figura 4.15). No primeiro ponto de ocorrência (ocorrência Sobar) 0 arenito asfáltico aflora no chão da estrada em área de reflorestamento. Em campo, aferiu-se uma espessura de 7,80 m de arenito asfáltico. Nas proximidades da ocorrência encontramse o contato entre a Formação Pirambóia e a Formação Teresina, cota $615 \mathrm{~m}$. Define-se que o arenito asfáltico encontra-se na base da Formação Pirambóia aproximadamente $10 \mathrm{~m}$ acima do contato.

\subsubsection{Jacutinga}

A ocorrência de Jacutinga localiza-se a sudoeste da cidade de Guareí, próximo à Escola do Bairro do Serrito, a $300 \mathrm{~m}$ ao norte da Capela Santa Cruz (Figura 4.6f).

Segundo Steveaux et al. (1980), esta ocorrência localiza-se no "Domo" de Jacutinga. Não foram observadas estruturas lineares em afloramento junto à ocorrência de Jacutinga. $\mathrm{Na}$ região, foram interpretados lineamentos (ETM+ Landsat 7) de direção leste-oeste a aproximadamente $1,5 \mathrm{~km}$ da ocorrência. Também são observados altos magnéticos a aproximadamente $4 \mathrm{~km}$ a nordeste e a sul da ocorrência. A região da ocorrência tem uma valor intermediário de susceptibilidade magnética e não apresenta anomalias magnéticas; portanto, deduz-se a inexistência de grandes corpos de rochas básicas, em subsuperfície, próximos à ocorrência.

O arenito asfáltico aflora na cota $660 \mathrm{~m}$, em um barranco de riacho a a aproximadamente $1,5 \mathrm{~m}$ de profundidade. A vegetação densa impediu uma melhor avaliação do afloramento.

No topo do afloramento, o betume está impregnado em arenito grosso de seleção boa, grãos subangulosos e aspecto maciço. Este tem espessura de aproximadamente $5 \mathrm{~m}$. Abaixo desta ocorrência encontra-se um arenito asfáltico listrado com $0,3 \mathrm{~m}$ de espessura e grãos de quartzo grossos. Abaixo aflora arenito médio de coloração amarela com níveis síltico argilosos. Este arenito é estéril e apresenta estratificação plano-paralela. Não foram notadas fraturas no afloramento, possivelmente devido ao intenso intemperismo e vegetação que recobria quase todo afloramento. Entretanto, nas amostras de mão foram notadas pequenas fraturas preenchidas por betume.

Nesta ocorrência, o betume impregna os arenitos da Fm. Tatuí. Pelas características observadas em campo, trata-se provavelmente da camada Ibicatu ou conglomerado Pitanga. Segundo Franzinelli (1972), três sondagens efetuadas pela Petrobrás revelaram que esse afloramento é restrito a uma lente de areia grossa da Formação Tatuí. 


\subsection{Geofísica}

\subsubsection{Gravimetria}

Além dos dados regionais obtidos, foi realizado um levantamento gravimétrico em uma região na porção sul da área de estudo. Este levantamento visou a obtenção de dados da área interpretada através de imagem de sensoriamento remoto, que se configura geomorfologicamente como uma estrutura anelar, ao norte da cidade de Angatuba, oeste de Guareí e sul de Pardinho. Na região localiza-se o domo de Carlota Prenz e o Estrutura do Jacu, as principais drenagens na área são o Rio Guareí e Córrego Jacu.

Foram levantados 372 pontos gravimétricos terrestres (Figura 4.16) utilizando-se um gravímetro Lacoste \& Romberg. A região coberta pelo levantamento tem uma área de aproximadamente $1225 \mathrm{~km}^{2}$, configura-se geometricamente como um quadrado de aproximadamente $35 \mathrm{~km}$ de lado.

A base gravimétrica utilizada localiza-se na cidade de Itapetininga, na Igreja Nossa Senhora dos Prazeres (Lat -23,5928; Long -48,0415), Praça Duque de Caxias. O gravímetro é colocado no patamar, ao lado de uma coluna na entrada principal da igreja, à direita de quem entra. A altitude no local é de $660 \mathrm{~m}$ e a gravidade é $978,63428 \mathrm{~cm} / \mathrm{s}^{2}$. A base faz parte da Rede Gravimétrica Fundamental do Estado de São Paulo (RGFESP).

A última fase de levantamento de dados gravimétricos em campo ocorreu na área de afloramento do Alto Estrutural de Anhembi. Esta área localiza-se na porção norte da área de estudo, junto à represa de Barra Bonita no Rio Tietê.

Nesta área foram levantados 163 pontos gravimétricos terrestres (Figura 4.17) utilizando-se novamente o gravímetro Lacoste \& Romberg do Instituto de Geociências e Ciências Exatas da UNESP em Rio Claro. A região coberta pelo levantamento tem uma área de aproximadamente $614 \mathrm{~km}^{2}$, configura-se geometricamente como um retângulo de aproximadamente $31,5 \mathrm{~km}$ de base e $19,5 \mathrm{~km}$ de altura.

A base gravimétrica utilizada localiza-se na cidade de Bofete, na Igreja Nossa Senhora da Piedade (UTM E 780863m; UTM N 7442458m, Meridiano Central -51). Esta base gravimétrica foi transferida nos primeiros dois dias do levantamento, a partir da base gravimétrica de Itapetininga.

O processamento das informações obtidas em campo foi feito utilizando um microcomputador portátil com processador Pentium de $700 \mathrm{Mhz}$. A partir da utilização deste equipamento em campo, foi possivel avaliar as anomalias gravimétricas e sua distribuição espacial, voltando aos pontos levantados e verificando os valores de leitura rapidamente.

O programa utilizado foi o REGRAV (Sá, 1994), que permitiu o rápido processamento das observações para as correções da deriva instrumental e da atração luni-solar, além da transformação de coordenadas e cálculo das anomalias gravimétricas (Bouguer). 
Com o banco de dados de anomalias Bouguer obtido no IAG/USP, foi feita a interpolação utilizando o método da mínima curvatura. Optou-se por uma grade de aproximadamente 2500 metros de lado para cada elemento. Este valor foi escolhido em função da densidade de amostragem deste banco de dados.

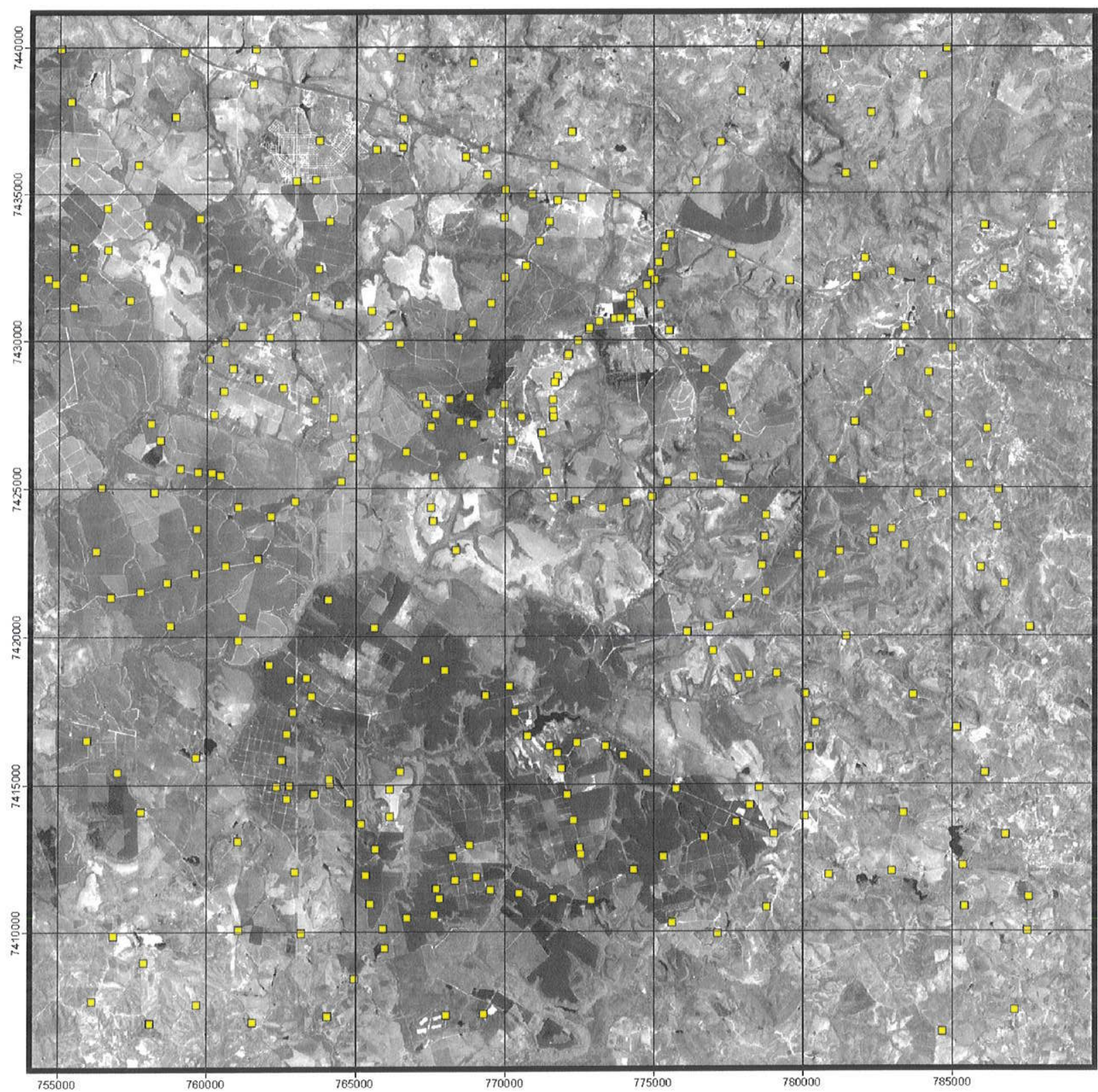

Figura 4.16: Distribuição dos pontos de leitura de observações gravimétricas - área Jacu. Imagem ETM+ Landsat 7 banda pancromática, coordenadas em metros. 


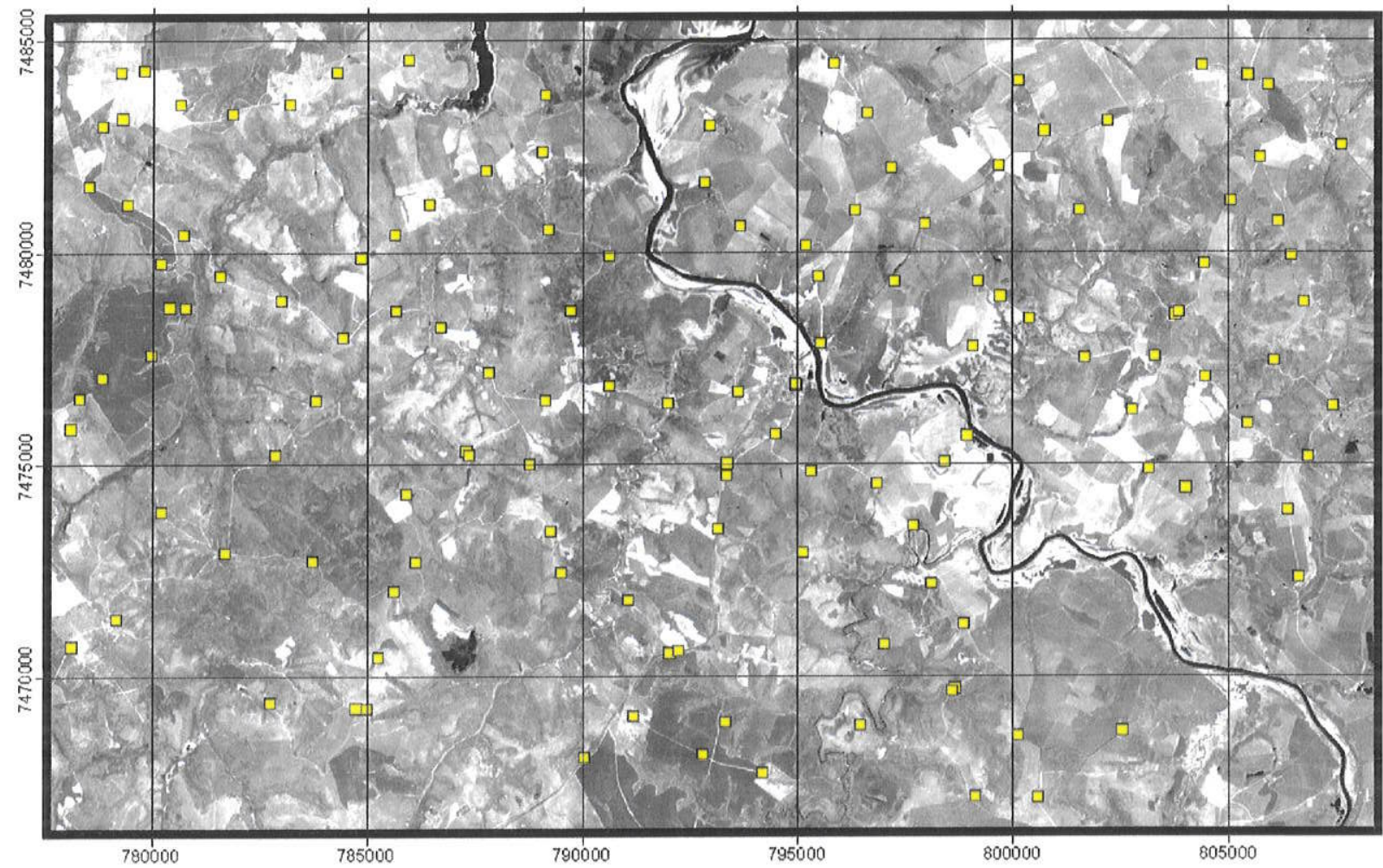

Figura 4.17: Distribuição dos pontos de leitura de observações gravimétricas - área Anhembi. Imagem ETM+ Landsat 7 banda pancromática, coordenadas em metros.

Com os dados do levantamento de campo, foram feitos o processamento e a redução das observações gravimétricas, obtiveram-se valores de anomalia Bouguer. Foi realizada a interpolação dos pontos (anomalia Bouguer) utilizando-se um interpolador do tipo mínima curvatura com tensão de 0.25. O espaçamento médio das observações é de aproximadamente 1,2 km para a área do Domo de Jacu e $1 \mathrm{~km}$ para a área de Anhembi. Deste modo, considerou-se esta densidade de amostragem para a definição da resolưção da grade de interpolação.

A Figura 4.18 mostra o mapa de anomalia Bouguer interpolado para a área Domo de Jacu (aproximadamente 600 metros de resolução). A Figura 4.19 apresenta o mapa de anomalia Bouguer da área de Anhembi (resolução de aproximadamente 500 m). 


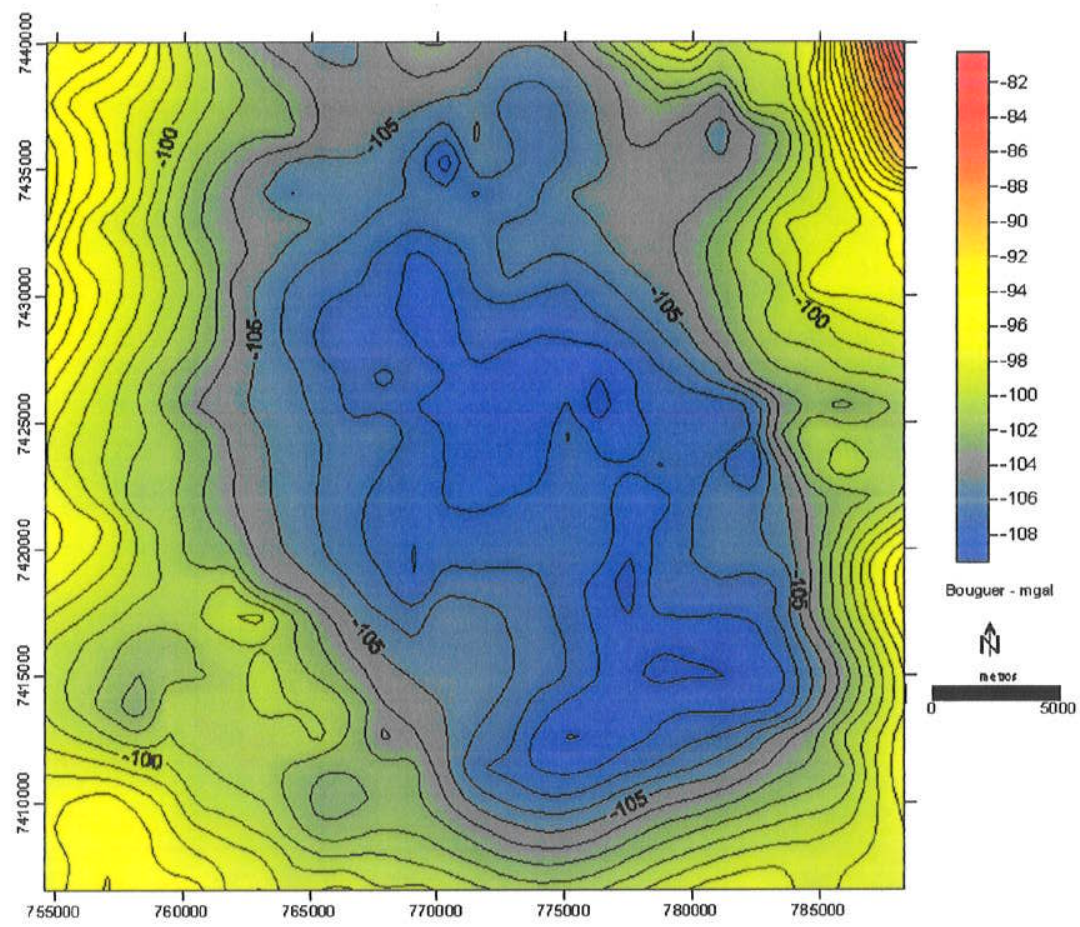

Figura 4.18: Mapa de anomalia - Bouguer - área Jacu.

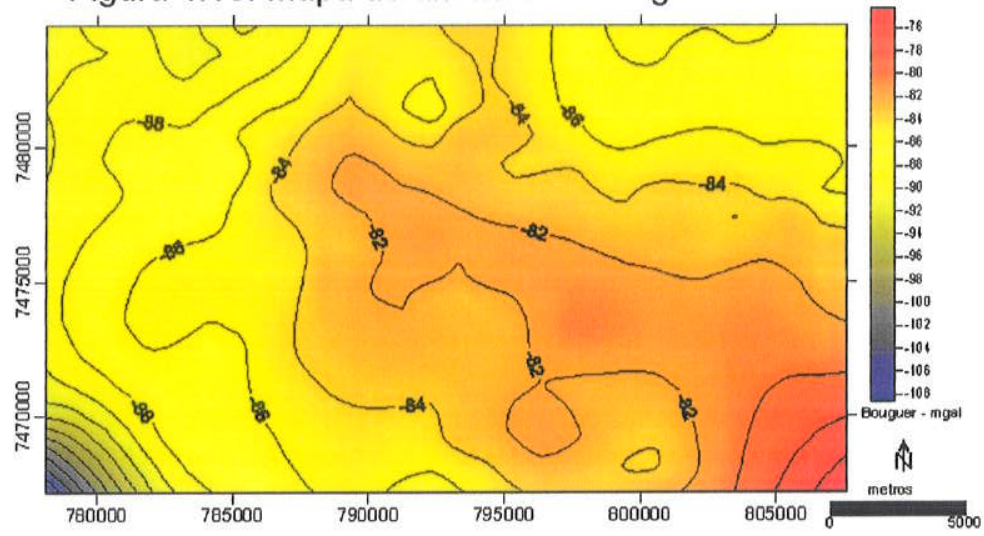

Figura 4.19: Mapa de anomalia Bouguer - área Anhembi.

Na Figura 4.20 observa-se a superposição dos três levantamentos gravimétricos. Deste modo, é possível fazer um controle preliminar dos resultados obtidos assegurando a consistência do levantamento e processamento. Regionalmente, a área de estudo caracteriza-se por baixos valores gravimétricos nas porções sudoeste e nordeste. A área da Estrutura do Jacu caracteriza-se por um grande baixo gravimétrico. Uma análise preliminar indica que este baixo pode ser ocasionado pela distribuição espacial de rochas ígneas básicas na área. 


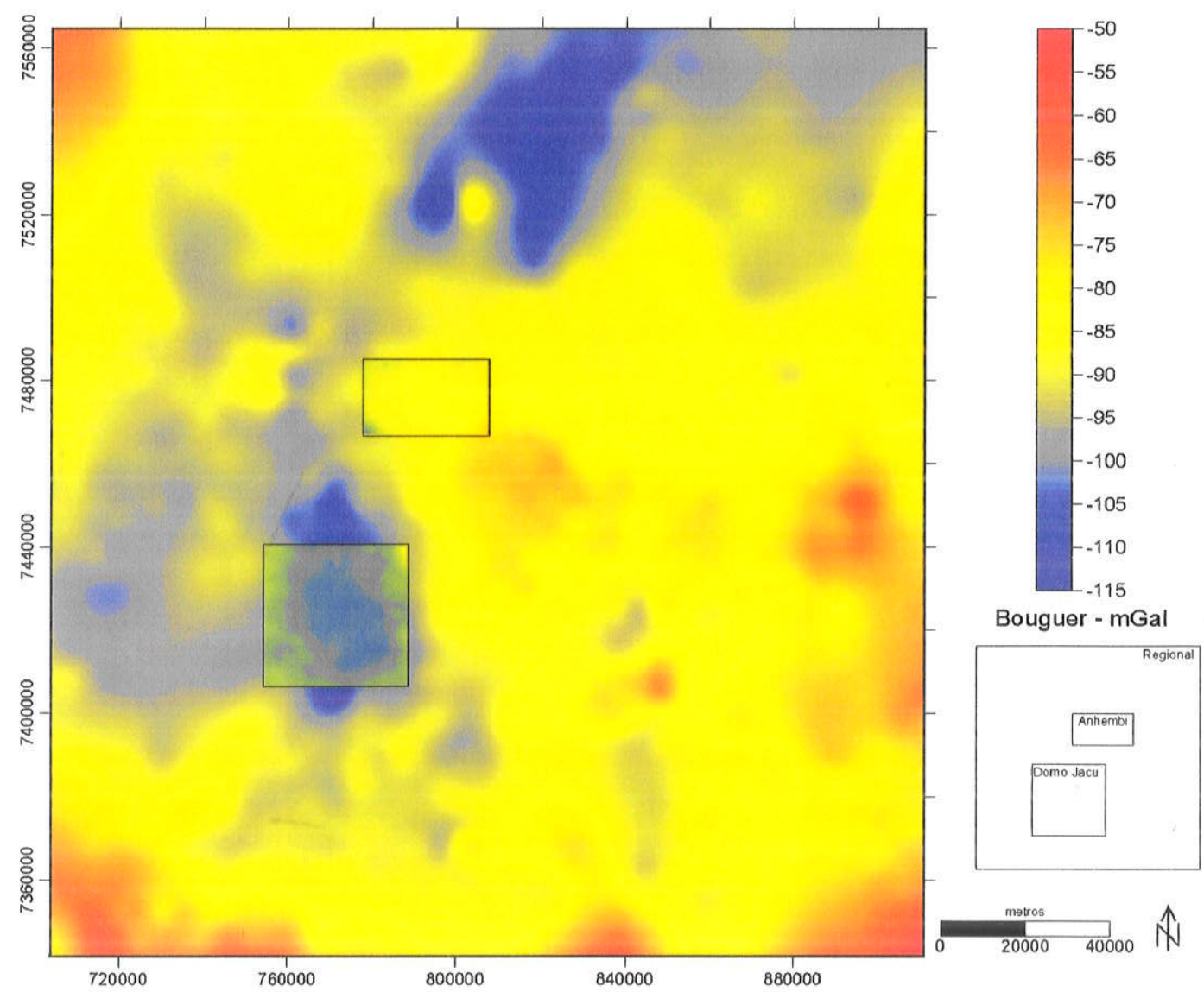

Figura 4.20: Mapa de anomalia Bouguer - levantamentos sobrepostos.

Observando-se o mapa geológico da área de estudo (Figura 4.5) nota-se que na borda nordeste deste baixo gravimétrico afloram os derrames da Serra de Botucatu. Na borda sudeste há presença do sistema de falhamentos Torre de Pedra e Guareí, além de várias soleiras e diques básicos. Esta disposição de litotipos proporciona um contraste de densidade que provoca uma anomalia gravimétrica de forma elíptica. 


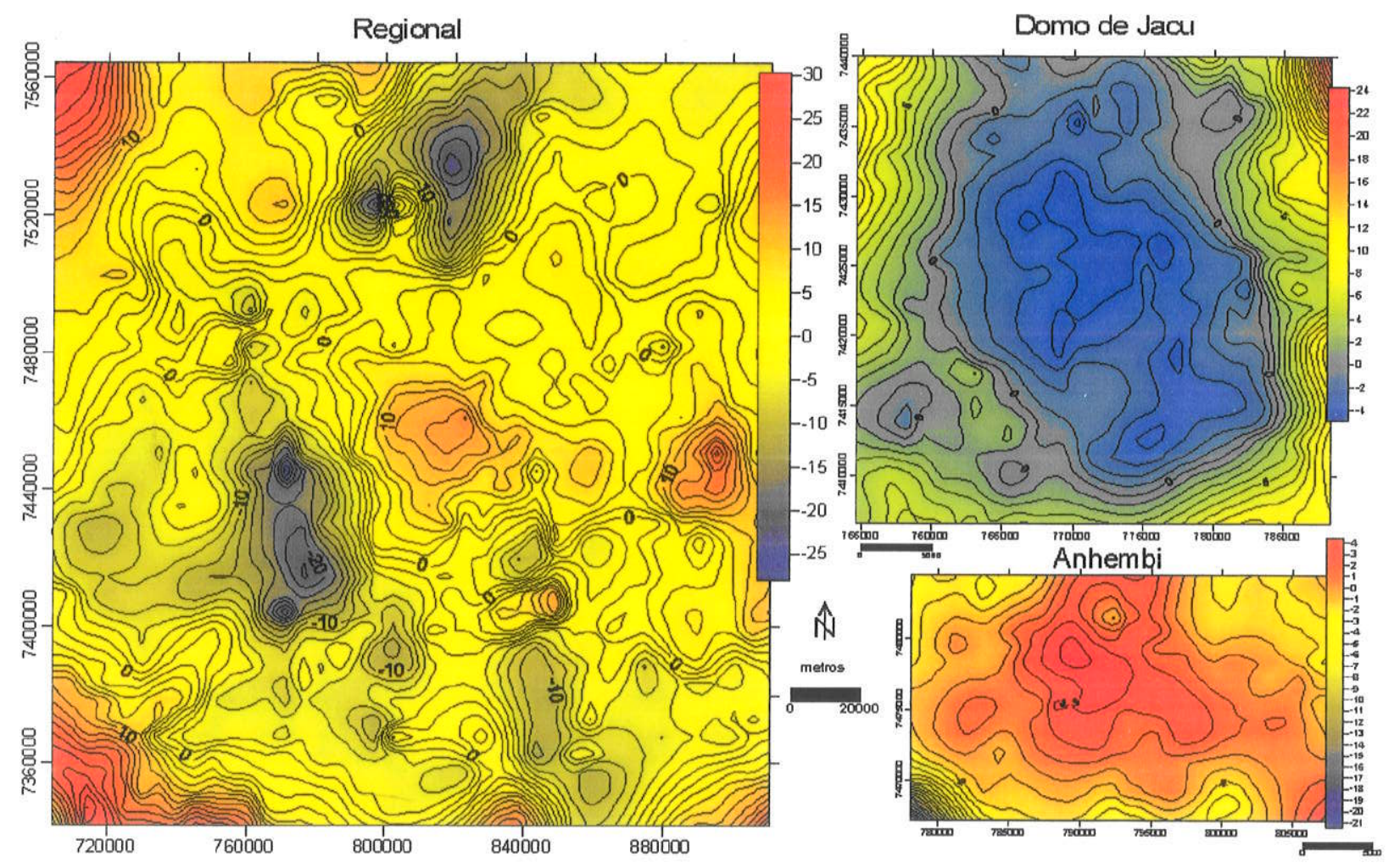

Figura 4.21: Mapas de resíduos de grau 1 da anomalia Bouguer.

Também foram gerados mapas de resíduos de superfícies de tendência de primeiro grau (Figura 4.21). Em princípio, a superfície de tendência de grau 1 contém o componente do campo regional, sua retirada permite o realce das anomalias relativas às fontes geológicas mais rasas.

\subsubsection{Interpretação de dados gravimétricos}

Para a interpretação dos dados gravimétricos, os seguintes aspectos foram considerados: altos gravimétricos (resíduos positivos), baixos gravimétricos (resíduos negativos), alinhamentos gravimétricos e inflexão de descontinuidades no relevo gravimétrico. A interpretação foi feita em um SIG utilizando os dados gravimétricos e residuais interativamente. A partir dos dados gravimétricos interpolados foram produzidas imagens sombreadas com iluminação a partir de N45E e inclinação de 45 graus.

O mapa de campo total (Bouguer) é considerado o resultado das respostas gravimétricas acumuladas de vários materiais na crosta, incluindo o embasamento e o pacote sedimentar com rochas vulcânicas básicas.

No mapa gravimétrico regional (Figura 4.22) destaca-se a presença de um forte alinhamento de altos e baixos gravimétricos na porção central do mapa. Este alinhamento tem direção NW e cruza a estrutura do Alto de Anhembi, que tem seu eixo maior com a mesma direção do alinhamento. Aparentemente, este alinhamento tem a mesma direção do 
eixo de drenagem do Rio Tietê, de modo que este alinhamento gravimétrico correponde aos alinhamentos estruturais do Tietê e Barra Bonita-Itu.

De modo geral, a partir dos dados gravimétricos, a estrutura do Jacu é uma área de baixo gravimétrico provavelmente relacionada a um baixo estrutural circundada por blocos altos (Figura 4.23). A área tem uma forma elíptica com eixo maior NW circundada por uma série de altos gravimétricos. A maior parte das ocorrências de arenito asfáltico está na região de inflexão entre os altos e baixos gravimétricos. Os altos gravimétricos são interpretados como indicativos de corpos densos enterrados, assim como altos estruturais. Na porção sudoeste da área há vários afloramentos da Soleira de Angatuba e do Alto Estrutural de Sobar. A Soleira de Angatuba é composta por rochas Juro-Cretáceas básicas, cuja intrusão extende-se por quilômetros. O Alto de Sobar é um alto estrutural em cujo centro afloram rochas permianas (Formação Teresina) circundadas por rochas do Triássico-Jurássico (Fm. Pirambóia). Na porção leste, os altos gravimétricos correspondem à área de afloramento de rochas permianas.

A estrutura do Jacu pode ser observada no mapa de anomalia Bouguer e mapa resíduos de $1^{\circ}$ grau (Figura 4.23). Observa-se que há correspondência entre os lineamentos interpretados no modelo numérico de terreno e na imagem de satélite com os lineamentos observados nos mapas gravimétricos e de resíduos. Os lineamentos NW são claramente detectáveis nos mapas gravimétricos da estrutura do Jacu, Alto de Anhembi e mapa regional. Os lineamentos NE aparecem com menor continuidade e, por vezes, são interrompidos pelas estruturas NW.

As estruturas de Sobar e Angatuba correspondem a altos gravimétricos. O Alto de Sobar (Domo de Carlota Prenz) está em uma área com um alto gravimétrico de alinhamento $\mathrm{N} 45 \mathrm{~W}$. Já a soleira de Angatuba está numa área com valores gravimétricos intermediários.

É importante notar que as intrusões provavelmente estão localizadas nas bordas da estrutura do Jacu (altos gravimétricos). Conclui-se que a estrutura do Jacu não é derivada de apenas uma única grande intrusão, mas é produto do desenvolvimento geomorfológico condicionado pelas estruturas principais localizados ao redor da estrutura do Jacu. Estas estruturas principais têm configuração NE-NW. Logo, o desenvolvimento geomorfológico da área, a partir de lineamentos NW-NE, pode ter gerado a anomalia anelar da estrutura do Jacu.

Em relação à estrutura do Jacu, as ocorrências de arenito asfáltico encontram-se nas porções intermediárias entre os altos e baixos gravimétricos, na Figura 4.23 é possível observar o posicionamento das ocorrências nas áreas de inflexão gravimétrica, tanto no mapa de campo total quanto no mapa de resíduo de $1^{\circ} \mathrm{grau}$. 

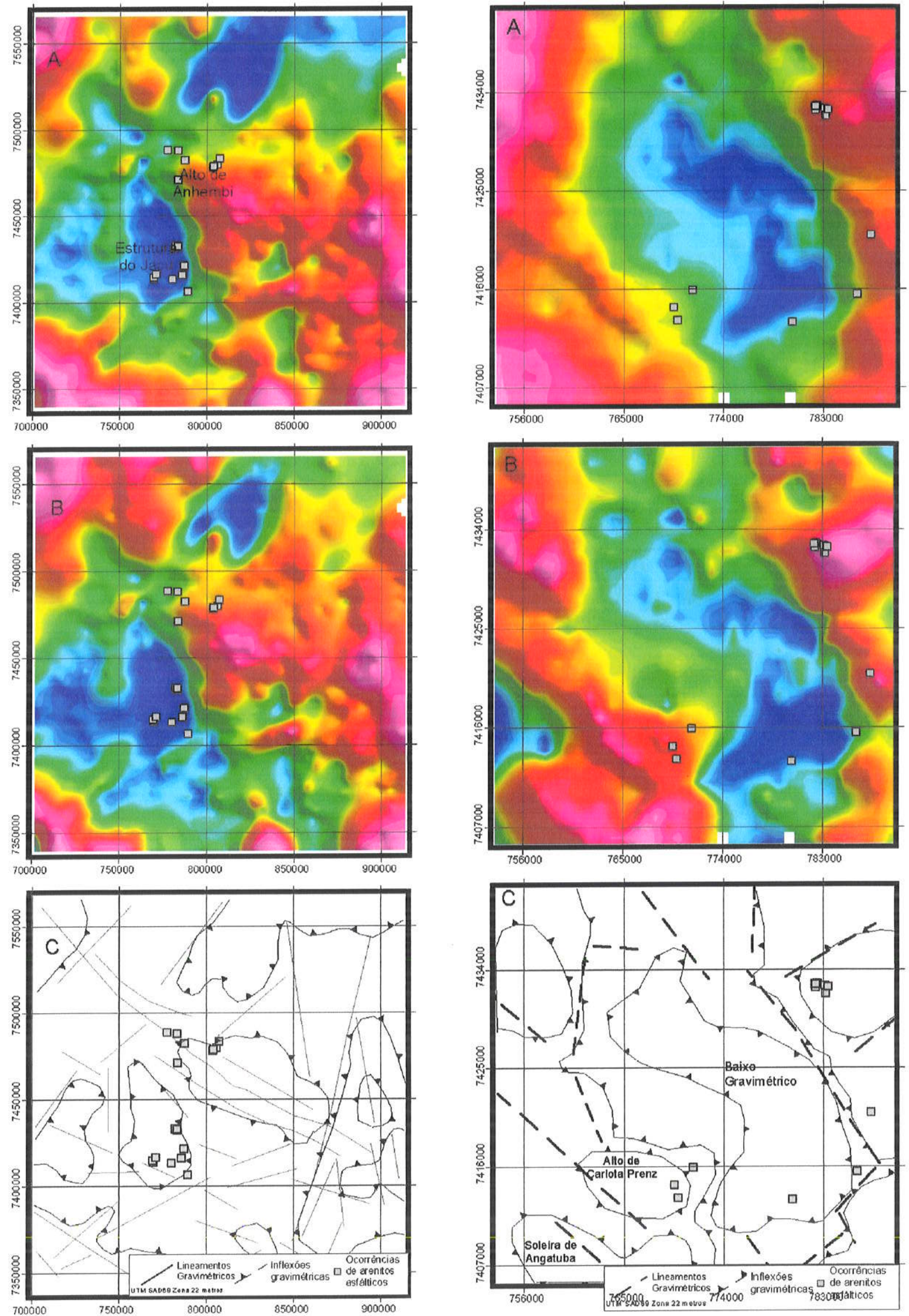

Figura 4.22: Gravimetria regional. A) Gravimetria Figura 4.23: Gravimetria Jacu. (A) Estrutura do regional Bouguer; (B) Resíduo de $1^{0}$ grau; (C) Jacu - Bouguer; (B) Resíduo de $1^{0}$ grau; (C) Intepretação. Intepretação. 
Observa-se no mapa gravimétrico na área da estrutura de Anhembi (Figura 4.24) uma forte tendência de alinhamentos de direção NW com direção geral N320, em menor número e mais segmentados há alinhamentos NE com direções que variam de N10 até N30. Poucos lineamentos de direção norte são observados, alguns na porção noroeste da área.
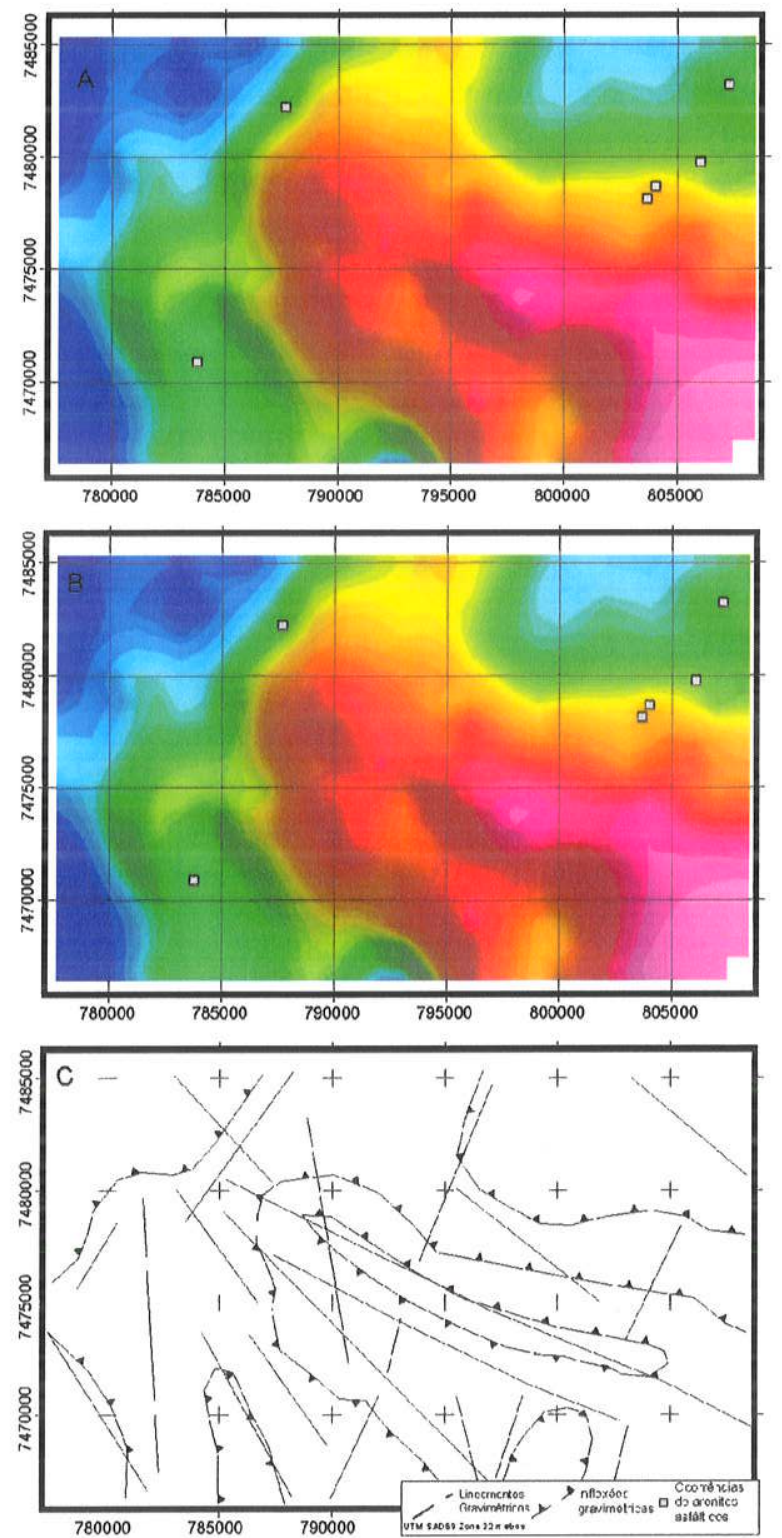

Figura 4.24: Imagens gravimétricas e interpretação na área do Alto Estrutural de Anhembi. (A) Campo total; (B) Resíduo de $1^{0}$ grau; (C) Interpretação.

O mapa gravimétrico do Alto de Anhembi é caracterizado, principalmente, por um forte alto gravimétrico de direção NW em sua porção central (Figura 4.24). Este alto gravimétrico coincide com a estruturação geológica superficial do Alto de Anhembi. Interpreta-se que nesta área haja um alto estrutural relacionado ao pacote sedimentar e ao embasamento, 
eventualmente diques e soleiras de rochas básicas também fazem parte dos elementos geológicos que explicam o comportamento gravimétrico da área. É importante ressaltar que, o comportamento e escala de valores dos alto gravimétrico induzem a interpretação de que embasamento foi soerguido na área. Como na área da estrutura do Jacu, as ocorrências de arenito asfáltico localizam-se nas porções entre baixos e altos gravimétricos, ou seja, nas zonas de inflexão gravimétrica.

\subsubsection{Aeromagnetometria}

A partir de uma imagem base filtrada com filtro co-seno direcional, para eliminar feições NS decorrentes de problemas de nivelamento, foram obtidas imagens de redução ao pólo, sinal analítico, $1^{\text {a }}$ derivada vertical e controle automático de ganho. Para a interpretação foi utilizada a imagem de campo total (Figura 4.25). Também foram utilizadas, de modo auxiliar, as imagens de sinal analítico (Figura 4.26) e $1^{\text {a }}$ derivada vertical (Figura 4.27). A imagem de controle automático de ganho (Figura 4.28) foi utilizada eventualmente para confirmação da interpretação de lineamentos pouco aparentes.

\subsubsection{Redução ao pólo}

Segundo Milligan \& Gunn (1997), a redução ao pólo é um processo de conversão do campo magnético de uma posição geográfica, onde o campo é inclinado, para uma nova posição para o campo magnético polar. No pólo a indução do campo magnético é vertical. Desse modo, as anomalias magnéticas em um mapa com redução ao pólo ocorrem verticalmente acima de suas fontes (Gunn et al., 1997), de tal modo que esses mapas são mais simples de se interpretar do que outros onde há inclinação magnética.

Para a redução ao pólo dos dados magnéticos da área de estudo utilizaram-se os parâmetros apresentados na Tabela 6.

Tabela 6: Parâmetros de redução ao pólo dos dados magnéticos.

\begin{tabular}{ll}
\hline Coordenada central da área & $-48^{\circ} 15^{\prime} 00^{\prime \prime} \mathrm{W} / 23^{\circ} 00^{\prime} 00^{\prime \prime} \mathrm{S}$ \\
Período & 1 de julho de 1980 \\
Inclinação & $-29^{\circ} 45^{\prime}$ \\
Declinação & $18^{\circ} 50^{\prime}$ \\
Intensidade total & 23424,519 \\
\hline
\end{tabular}

Os parâmetros de redução ao pólo foram baseados no mapa magnético do Brasil do IBGE (1990a,b), escala 1:10.000.000. Os elementos utilizados foram: declinação, inclinação e intensidade total. 


\subsubsection{Micronivelamento e Filtragem direcional}

Nos grids resultantes da interpolação de bancos de dados nivelados, ainda nota-se elongações ao longo da direção de vôo. Estas feições podem ser corrigidas utilizando procedimentos de filtragem direcional ou micronivelamento. Entretanto, nenhum dos procedimentos caracteriza-se por considerar se a feição elongada é derivada de problemas no nivelamento do banco de dados ou sua origem é geológica.

O procedimento de micronivelamento adotado é o de micronivelamento utilizando interpolação bi-direcional (Geosoft Technical Note 2002; www.geosoft .com).

A filtragem direcional também pode atenuar os problemas de nivelamento do banco de dados. Contudo, este procedimento é aplicado apenas nos grids interpolados. Não há alteração do banco de dados original. Segundo Vasconcellos et al. (1994), os filtros cossenodirecional são excelentes para corrigir problemas de nivelamento, pois praticamente mantém as feições geofísicas ao longo da direção de filtragem com atenuação mínima das amplitudes.

Foi feita a aplicação dos dois métodos de correção de feições elongadas de nivelamento. Como visualmente, os resultados foram os mesmos, foi considerado o filtro cosseno-direcional, pela sua facilidade de implementação.

\subsubsection{Sinal Analítico}

O sinal analítico pode ser definido como um tipo de redução ao pólo, sem, contudo, estar sujeito à instabilidade decorrente das transformações dos campos magnéticos de baixa latitude.

De acordo com Milligan \& Gunn (1997), o sinal analítico é uma função relacionada aos campos magnéticos através de derivadas $(x, y, z)$. Segundo estes autores, já que esta função não é um parâmetro mensurável, é extremamente interessante para a interpretação pois é totalmente independente da direção de magnetização e direção do campo magnético da Terra. Isto significa que todos os corpos com a mesma geometria têm o mesmo sinal analítico. Além disso, segundo Milligan \& Gunn (1997), como os picos das funções do sinal analitico são simétricos e ocorrem diretamente sobre os limites de corpos largos e diretamente sobre centros de corpos delgados, a interpretação do sinal analítico, em princípio é simples e de fácil entendimento da geometria das fontes magnéticas (Figura 4.26).

Sinal analítico:

$$
|A(x, y, z)|=\left(\left(\frac{\partial m}{\partial x}\right)^{2}+\left(\frac{\partial m}{\partial y}\right)^{2}+\left(\frac{\partial m}{\partial z}\right)^{2}\right)
$$

onde $\mathrm{m}=$ anomalia magnética 


\subsubsection{4 $1^{\mathrm{a}}$ Derivada Vertical}

Segundo Milligan \& Gunn (1997), a primeira derivada vertical (ou gradiente vertical) é fisicamente equivalente a medição do campo magnético simultaneamente em dois pontos, verticalmente um acima um do outro, subtraindo o dado e dividindo o resultado pela distância vertical medida entre os pontos. Este procedimento realça as altas freqüências em relação às baixas freqüências. Deste modo, são eliminados efeitos regionais relacionados a comprimentos de onda longos. O resultado é uma imagem onde as anomalias adjacentes são bem definidas (Figura 4.27). Para os dados utilizados, este processamento é tão importante quanto a técnica do sinal analítico.

Segundo Milligan \& Gunn (1997), o cáiculo de derivadas verticais do campo magnético podem ser feitas computacionalmente através da multiplicação da amplitude do espectro do campo por um fator.

\subsubsection{Controle Automático de Ganho}

O controle automático de ganho converte as ondas de amplitude variável em ondas de amplitude semi-constante. O resultado é a retirada da informação de amplitude, produzindo uma representação de dados que enfatiza igualmente sinais de alta e baixa amplitude.

Para o mapeamento estrutural, esta técnica permite mostrar alinhamentos não aparentes em dados de amplitude verdadeira. $\mathrm{Na}$ interpretação dos dados, buscou-se utilizar a imagem de controle automático de ganho de modo auxiliar (Figura 4.28). Ou seja, os lineamentos dúbios foram comparados à resposta do controle automático de ganho e então puderam ser confirmados. Procurou-se não interpretar lineamentos baseados exclusivamente na imagem de controle automático de ganho.

\subsubsection{Interpretação de dados aeromagnéticos}

A interpretação (Figura 4.29) considerou dois aspectos: lineamentos magnéticos e texturas das porções de altos magnéticos. Os lineamentos magnéticos foram interpretados como diques de rochas básicas e falhas. Os altos magnéticos foram interpretados associados à presença de rochas básicas, sejam derrames ou intrusões.

As áreas onde a textura apresenta uma alta freqüência de altos magnéticos foram consideradas como dominadas por rochas extrusivas. A alta freqüência de altos magnéticos indica fontes superficiais. As áreas onde a freqüência é média a baixa foram consideradas como dominadas por rochas intrusivas. Notou-se na área, a dominância de alinhamentos de altos magnéticos de direção $\mathrm{N} 45 \mathrm{~W}$, que demonstra a influência do magmatismo do Arco de Ponta Grossa na área. Entretanto, as feições de baixa freqüência de altos magnéticos e as feições alinhadas de baixos magnéticos tendem à direção N45E, relacionadas ao trend do embasamento 
A área da estrutura do Jacu é caracterizada por um forte alinhamento de altos magnéticos de direção NW alinhados junto à Serra de Botucatu. Este alinhamento sofre uma inflexão na região de Torre de Pedra, onde nota-se novo lineamento de direção norte-sul. Desde a região de Porangaba até os arredores de Angatuba há alinhamento de altos magnéticos (NE) interpretados como relacionados, principalmente, à presença de soleira e diques básicos. A soleira de Angatuba (Fúlfaro, 1967) encontra-se na porção sul deste alinhamento. Deste modo, caracteriza-se o Domo de Jacu como circundado por altos magnéticos em sua porção NE, E e SW com presença de dipólo no centro da estrutura. Interpreta-se o Domo de Jacu como uma anomalia de drenagem relacionada aos altos estruturais causados pela intrusão de diques e soleiras da Fm. Serra Geral.

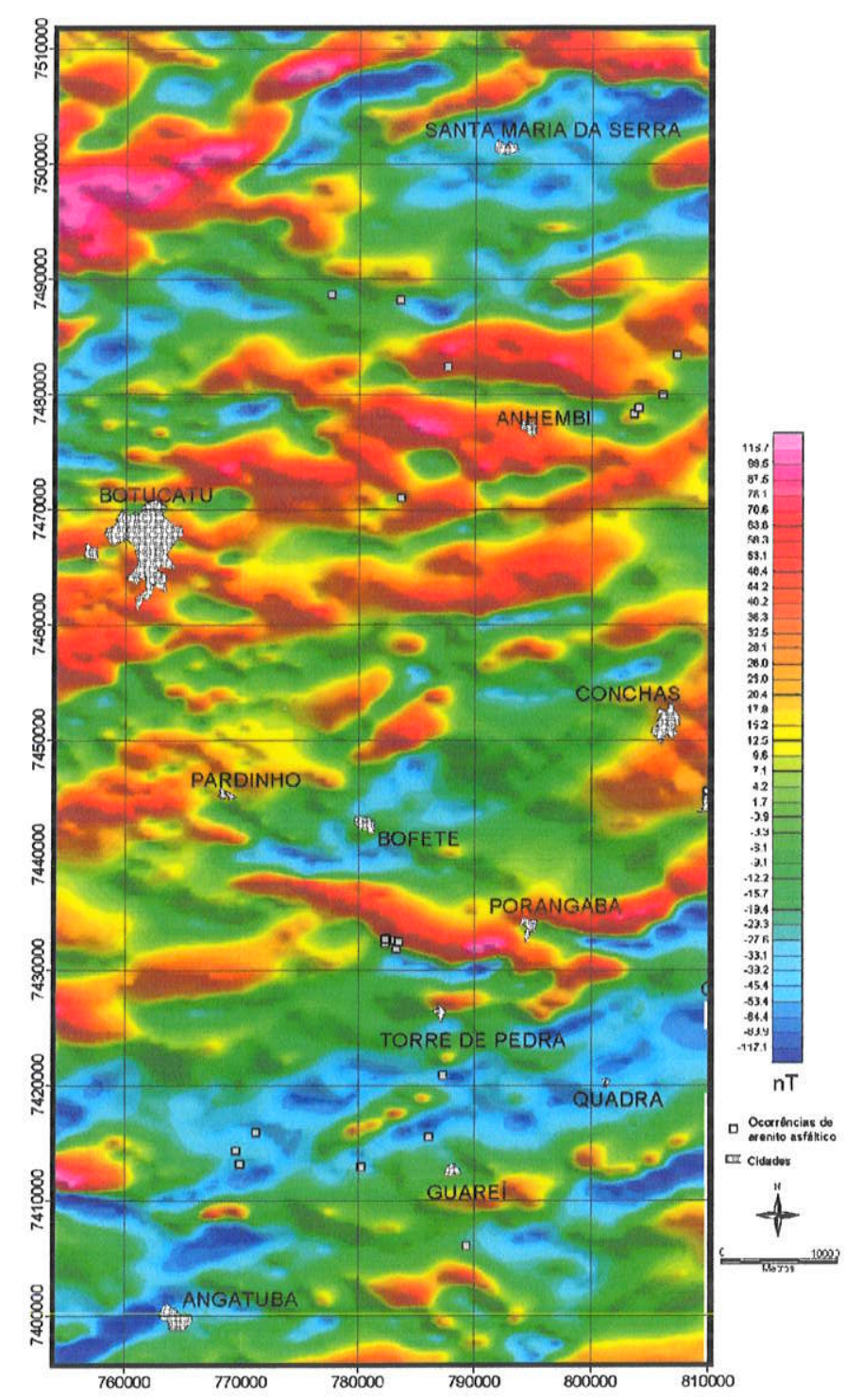

Figura 4.25: Aeromagnetometria, campo total. 


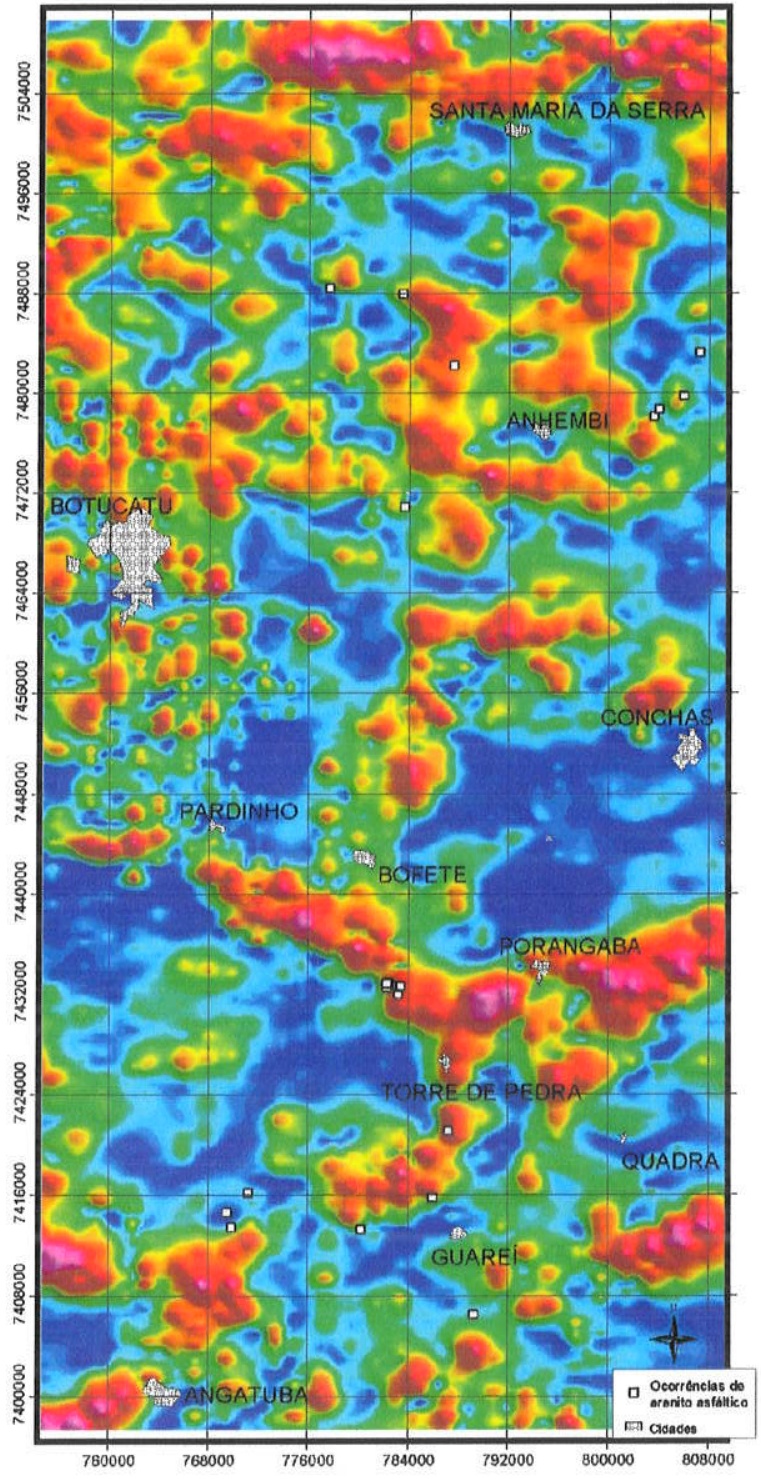

Figura 4.26: Sinal analítico

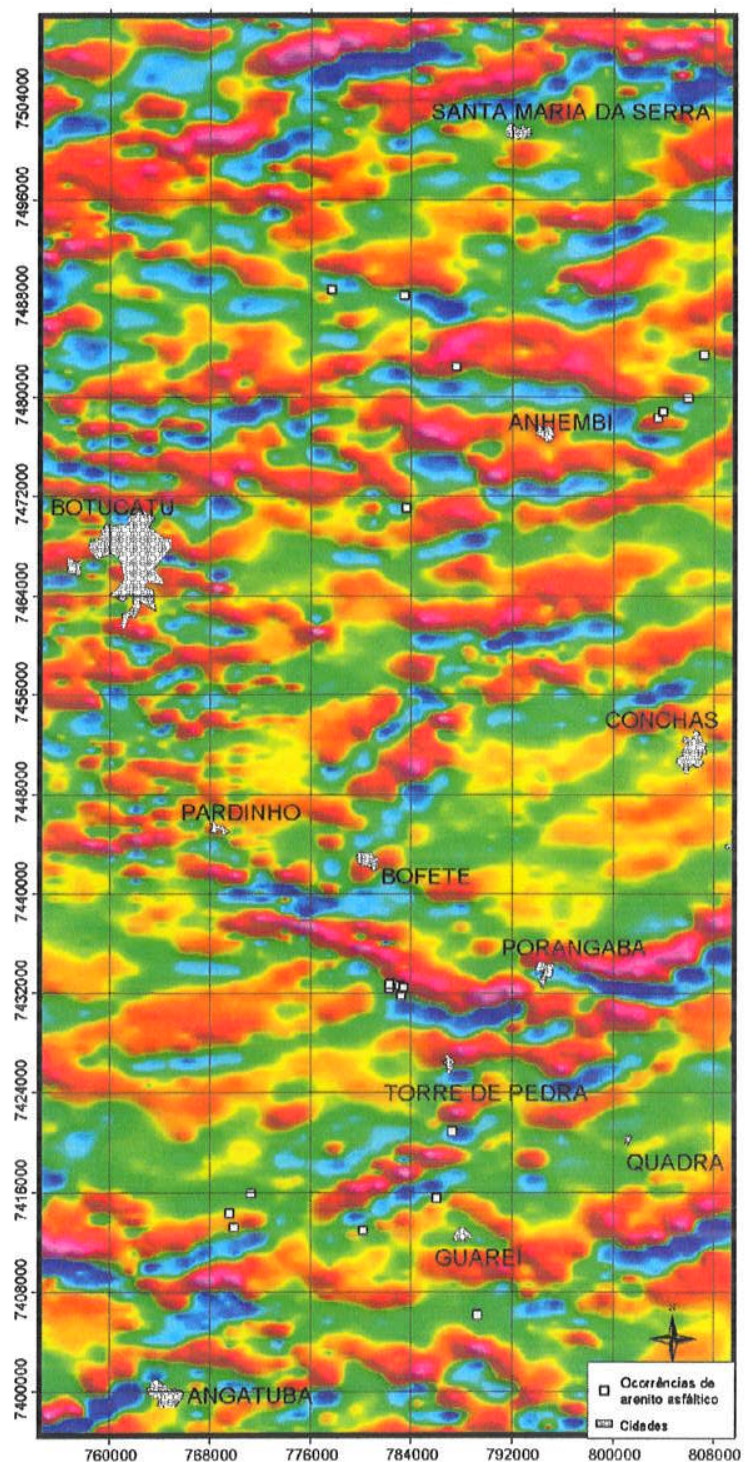

Figura 4.27: $1^{\mathrm{a}}$ derivada vertical. 
$\mathrm{Na}$ região da estrutura do Jacu, as ocorrências de arenitos asfálticos encontram-se espacialmente nas áreas de alinhamento de altos magnéticos. Estas áreas caracterizam-se pela presença de intrusões ígneas: regiões de fragilidade crustal propensas à movimentação tectônica. No mapa de $1^{\text {a }}$ derivada vertical da aeromagnetometria (Figura 4.27) é possível observar a localização preferencial das ocorrências de arenito asfáltico nas áreas de alinhamento de altos magnéticos e zonas de inflexão.

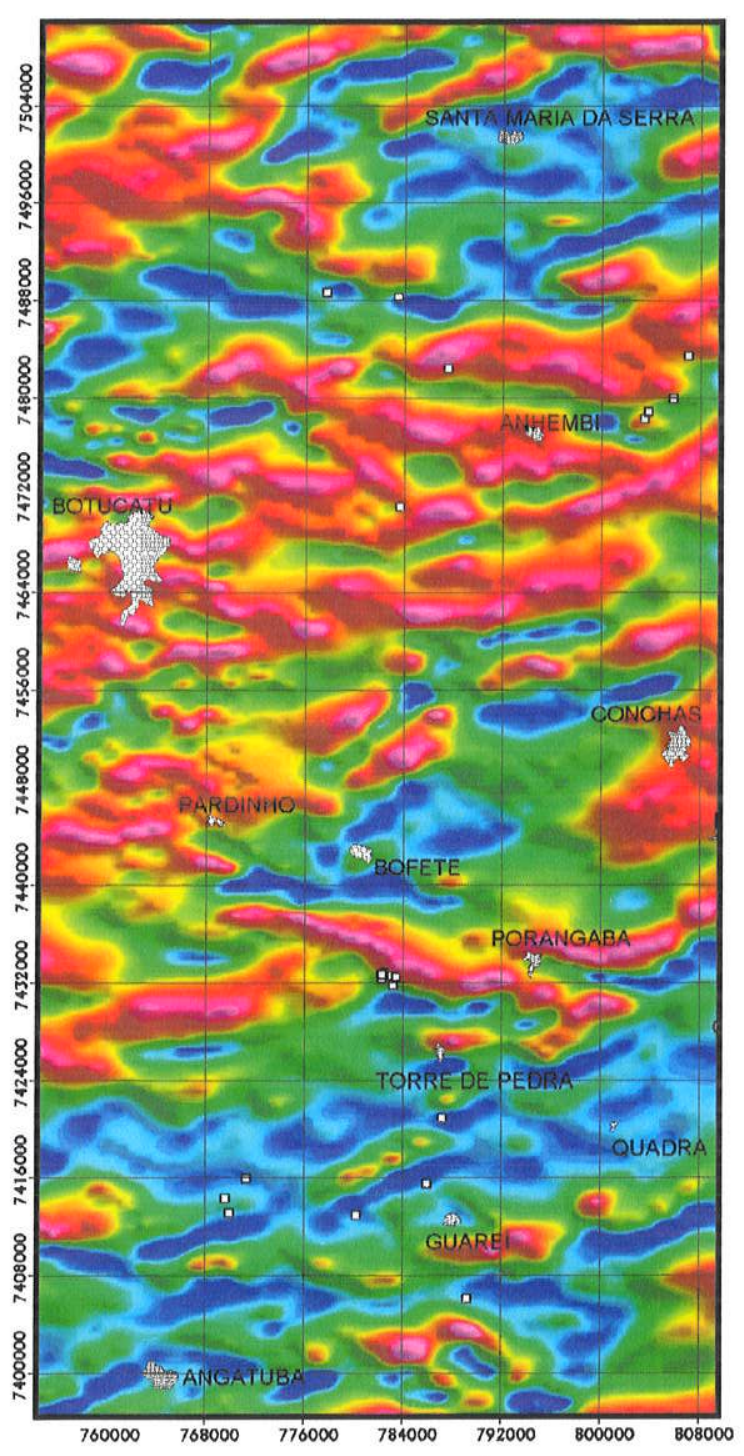

Figura 4.28: Controle Automático de Ganho.

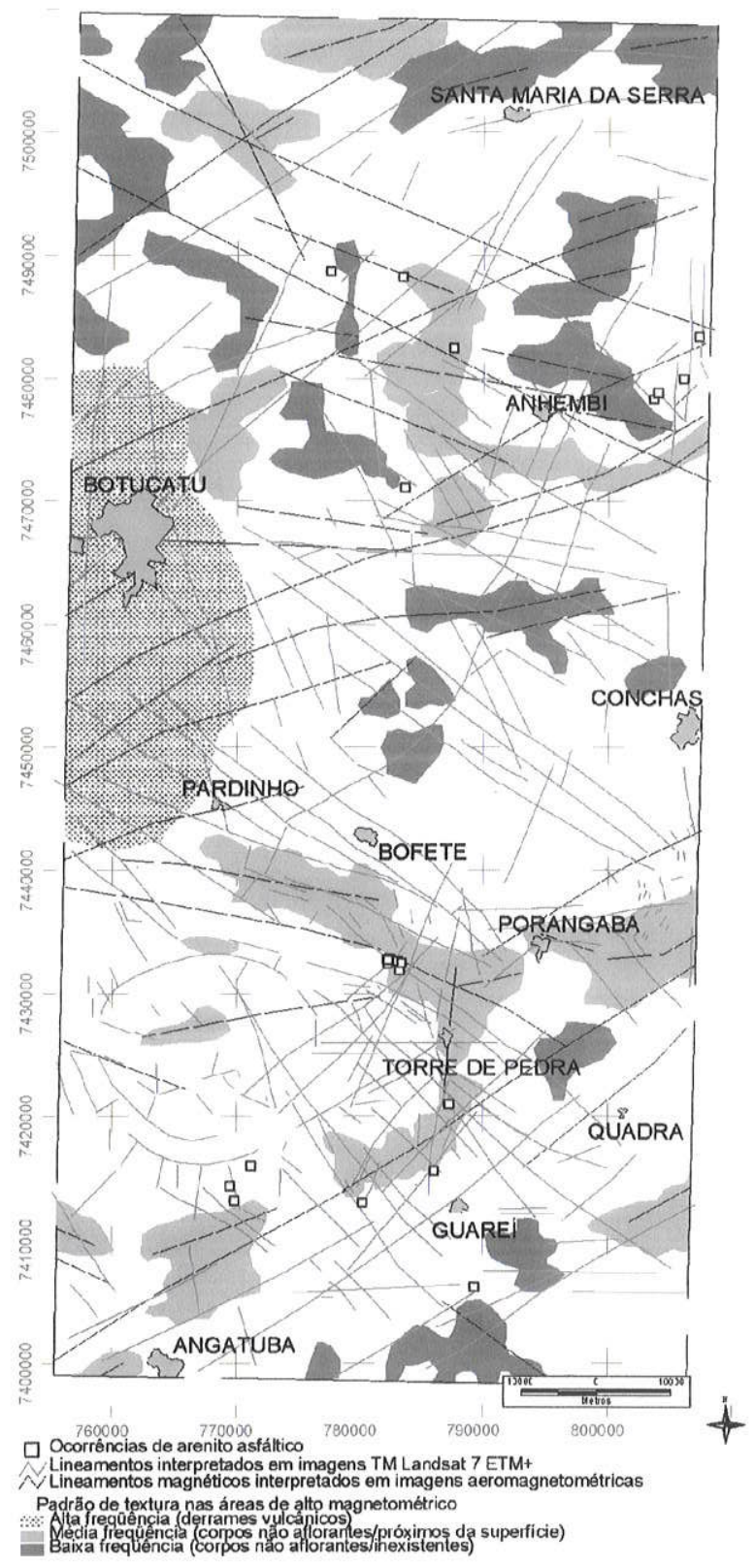

Figura 4.29: Interpretação de lineamentos magnéticos. 
A região do Alto de Anhembi é caracterizada pela interseç̧ão de lineamentos magnéticos NE e NW formando romboedros. Na região do alto estrutural ocorre uma anomalia magnética quilométrica indicativa da presença de corpo básico intrusivo. Este alto magnético de direção NW localiza-se à sudoeste da cidade de Anhembi, na direção da Vila Piapara. Na região ao norte do Alto de Anhembi, há presença de um outro alto magnético também de direção NW. Estes altos magnéticos são limitados por lineamentos magnéticos de direção NE. Interpreta-se que a anomalia magnética de direção NW esteja relacionada à gênese da estrutura de Anhembi durante eventos tectônicos ocorridos a partir do Permiano até o Triássico-Jurássico, e principalmente relacionada à Reativação Pós-Paleozóica. Os lineamentos magnéticos NE, caracterizados como limites da estrutura, foram gerados a partir de zonas de fraqueza do embasamento que sofreram intrusões de rochas básicas.

As ocorrências de arenitos asfálticos na região de Anhembi localizam-se na região dos lineamentos magnéticos, sejam de direção nordeste ou noroeste. A relação entre os lineamentos magnéticos e as ocorrências não é tão clara na região da Anhembi quanto na região do Domo de Jacu. Infere-se que os sinais magnéticos na área do Alto de Anhembi sejam atenuados em função de uma cobertura sedimentar mais espessa e da presença de corpos básicos de menor dimensão na área. Entretanto, reconhece-se no mapa aeromagnetométrico a presença da faixa de lineamentos NE e do Lineamento Tietê e lineamento Barra BonitamItu, faixa de lineamentos NW.

\subsubsection{Magnetometria terrestre}

Os dados obtidos no levantamento terrestre são de campo total com correção da variação diurna. Para a análise espacial foram feitas interpolações dos dados pontuais para gerar imagens magnetométricas (Figuras 4.30 e 4.31). Devido a área restrita dos alvos optou-se por simplificar o processo de análise. Deste modo, utilizaram-se apenas as imagens de campo total e sinal analítico.

Entre as ocorrências de arenito asfáltico, as ocorrências de Nhaíva e Betumita têm diques de rochas básicas associados às acumulações. A ocorrência Nhaíva, onde há um dique de rocha básica aflorante, tem a maior variação de valores de resposta magnética provavelmente devido ao afloramento. Já a ocorrência Betumita tem variação restrita de valores, provavelmente devido ao dique de rocha básica não ser aflorante. Desse modo, espera-se que a maioria das ocorrências tenha variação de medidas magnéticas semelhantes ao verificado na ocorrência Betumita. Esse comportamento pode ser verificado na Tabela 7. 
Tabela 7: Sumário dos dados de medição magnética terrestre.

\begin{tabular}{|l|l|l|l|l|l|l|}
\hline Alvo & $\begin{array}{l}\text { Valor médio } \\
\text { (nT) }\end{array}$ & $\begin{array}{l}\text { Máximo } \\
\text { (nT) }\end{array}$ & $\begin{array}{l}\text { Mínimo } \\
\text { (nT) }\end{array}$ & $\begin{array}{l}\text { Range } \\
\text { (nT) }\end{array}$ & $\begin{array}{l}\text { Desvio } \\
\text { padrão }\end{array}$ & $\begin{array}{l}\text { N. de } \\
\text { amostras }\end{array}$ \\
\hline Morro do Bofete & 22986,93 & 23658,63 & 22516,96 & 1141,67 & 125,01 & 265 \\
\hline Nhaíva & 23026,20 & 24353,88 & 21652,88 & 2701,00 & 319,92 & 79 \\
\hline Betumita & 23087,65 & 23331,16 & 22989,16 & 342,00 & 58,93 & 115 \\
\hline Moquém & 23110,52 & 23236,00 & 22774,31 & 461,69 & 83,67 & 87 \\
\hline Braço da Represa & 23139,51 & 23187,00 & 23079,00 & 108 & 21.96 & 70 \\
\hline Itatigue & 23022,41 & 23226,33 & 22909,67 & 316,66 & 54,77 & 46 \\
\hline Sobar & 22957,22 & 23071,67 & 22826,67 & 245,00 & 34,71 & 71 \\
\hline
\end{tabular}

O resultado dos dados medidos e interpolados pode ser observado nas figuras 4.30 e 4.31. Baseado nos dados dos alvos Nhaíva e Betumita, utilizou-se um modelo tabular vertical para interpretação. Entre os alvos há bastante semelhança com os resultados obtidos na ocorrência Betumita, daí interpreta-se que existam diques de rochas básicas nas seguintes ocorrências: Morro do Bofete, Bairro da Mina, Estrada da Mina, Itatigue, Nhaíva, Fazenda São Jorge, Betumita e Moquém. No alvo Braço da Represa o valor de variação é bastante reduzido, contudo há uma direção definida de variação dos valores magnéticos (Figura 4.30), intepreta-se uma provável falha junto à ocorrência de arenito, mas ausência de dique de rocha básica. Na ocorrência Sobar (Figura 4.31) a variação das medições magnéticas é pequena e não se encontra uma direção definida de anomalia magnética. É provável que para o alvo Sobar, a amostragem não foi suficiente para detectar anomalias, além disso a área de amostragem não cobriu todas as ocorrências do local (Sobar I, II e III). 


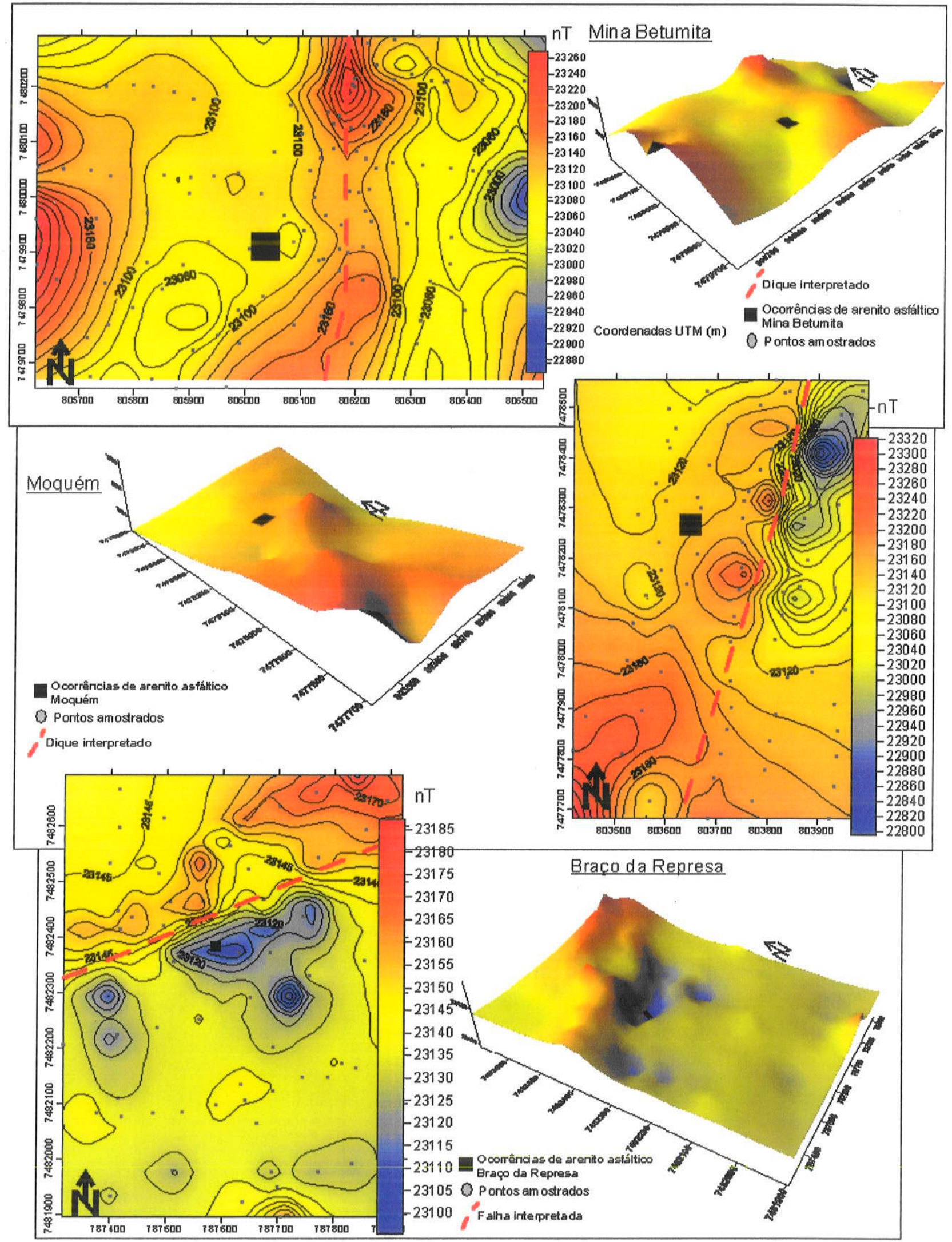

Figura 4.30:Apresentação dos mapas magnéticos e interpretações dos alvos na porção norte da área de estudo: Mina Betumita, Moquém e Braço da Represa. 


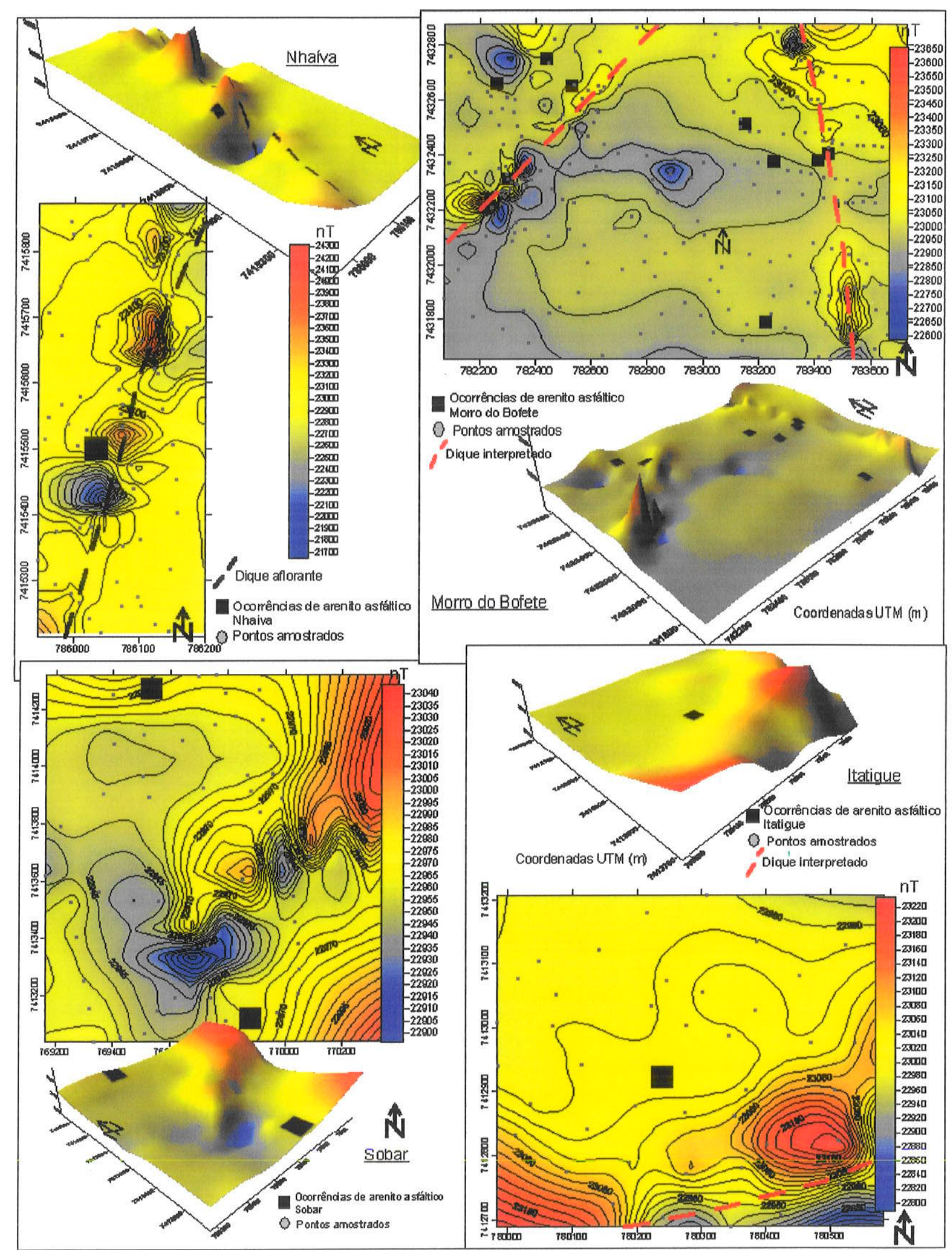

Figura 4.31: Apresentação dos mapas magnéticos e interpretações dos alvos na porção sul da área de estudo: Morro do Bofete, Nhaíva, Itatigue e Sobar. 
Foi executado o processamento de sinal analítico nas imagens, os resultados apresentados nas Figuras 4.32, 4.33, 4.34, 4.35, 4.36, 4.37 e 4.38 confirmam as interpretações feitas nas imagens de campo total.
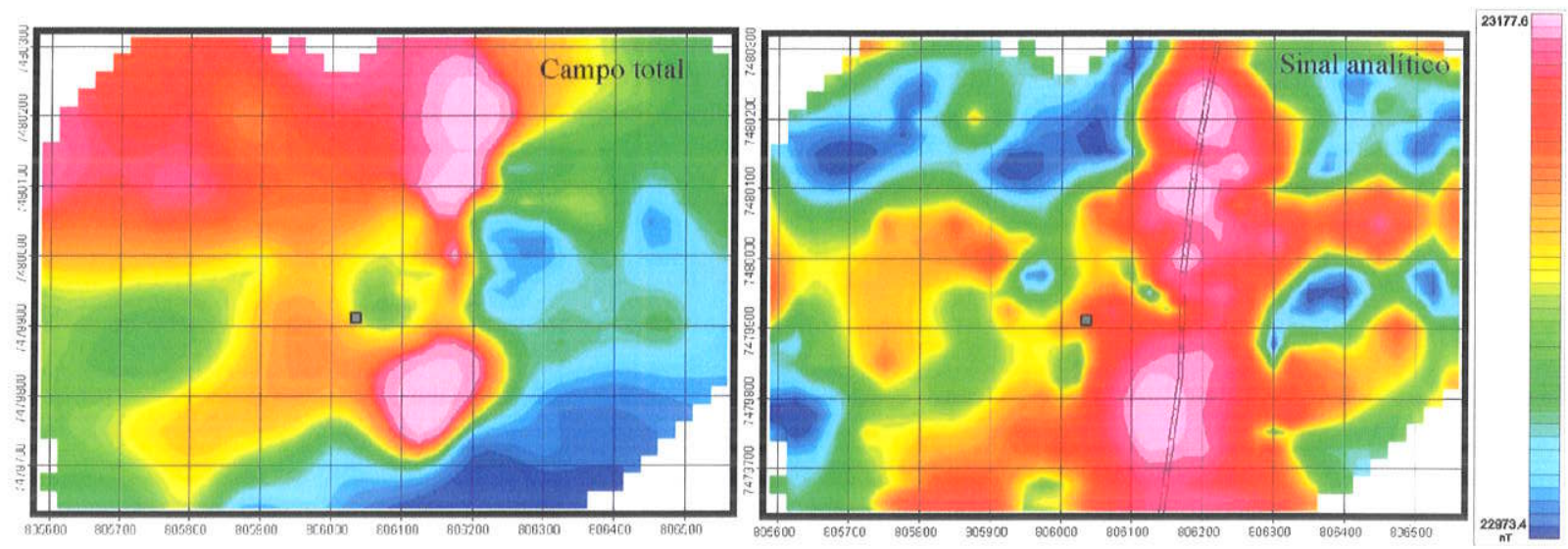

Figura 4.32: Comparação entre campo total e sinal analítico - Betumita.
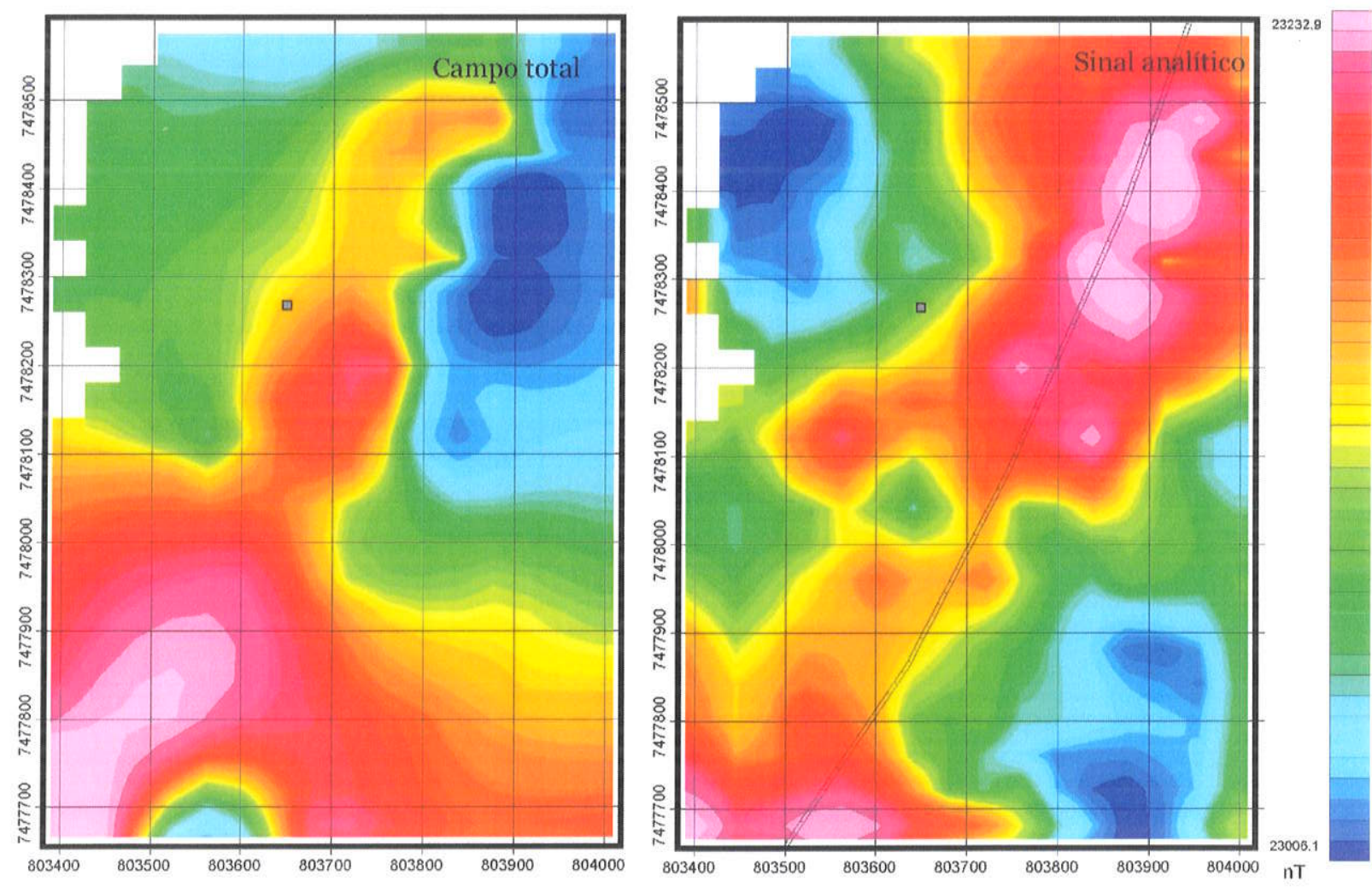

Figura 4.33: Comparação entre campo total e sinal analítico - Moquém. 

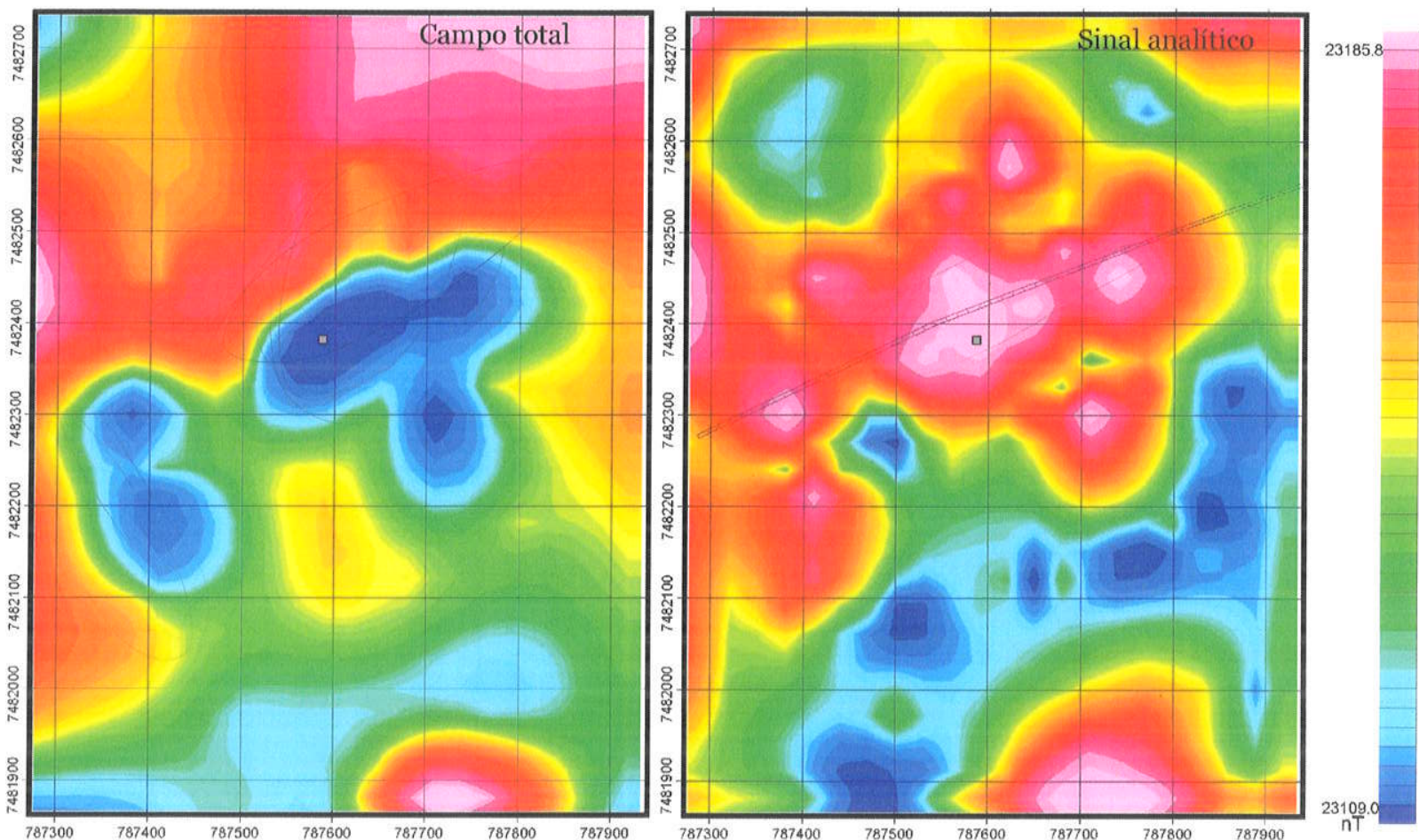

Figura 4.34: Comparação entre campo total e sinal analítico - Braço da Represa. 


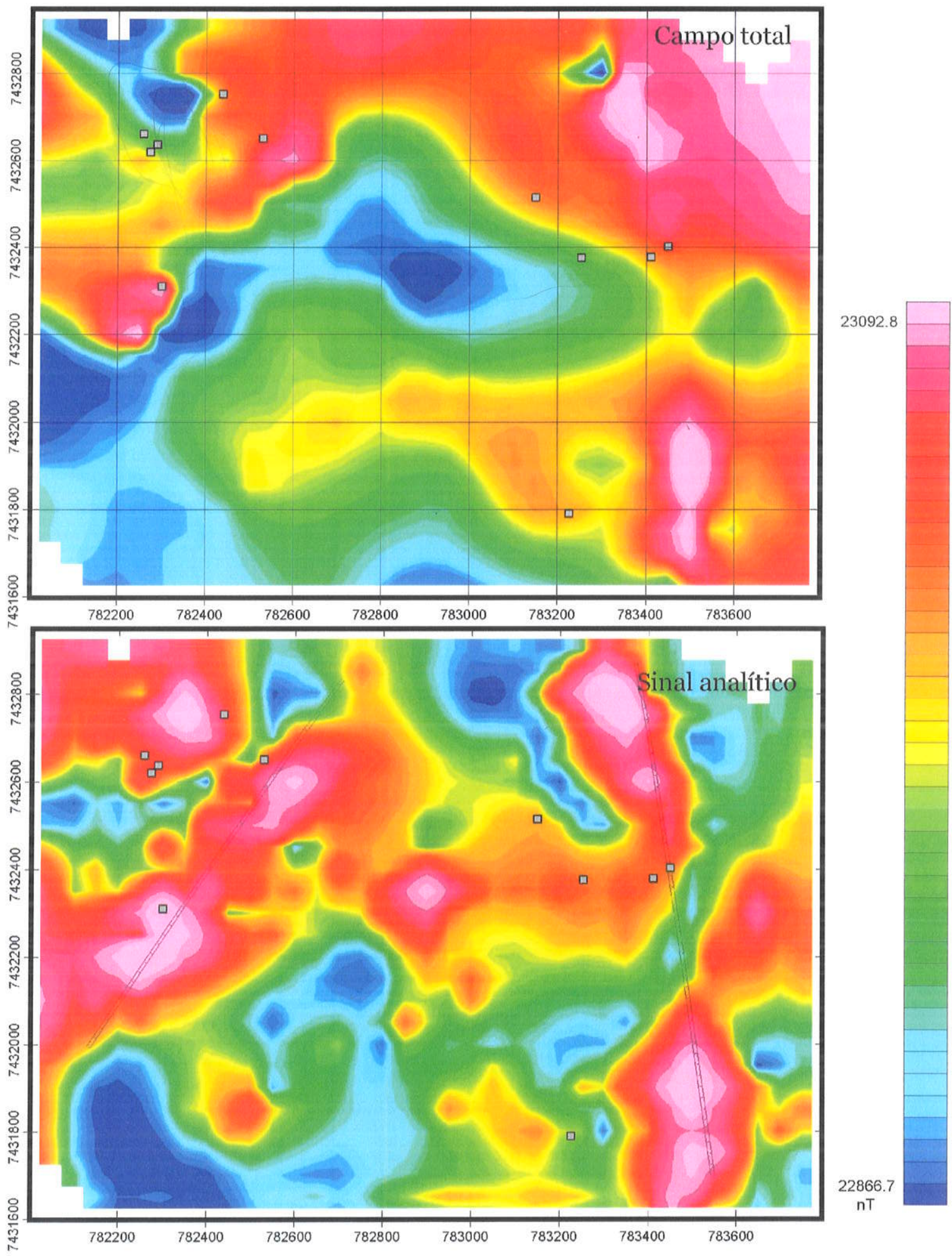

Figura 4.35: Comparação entre campo total e sinal analítico - Morro do Bofete. 

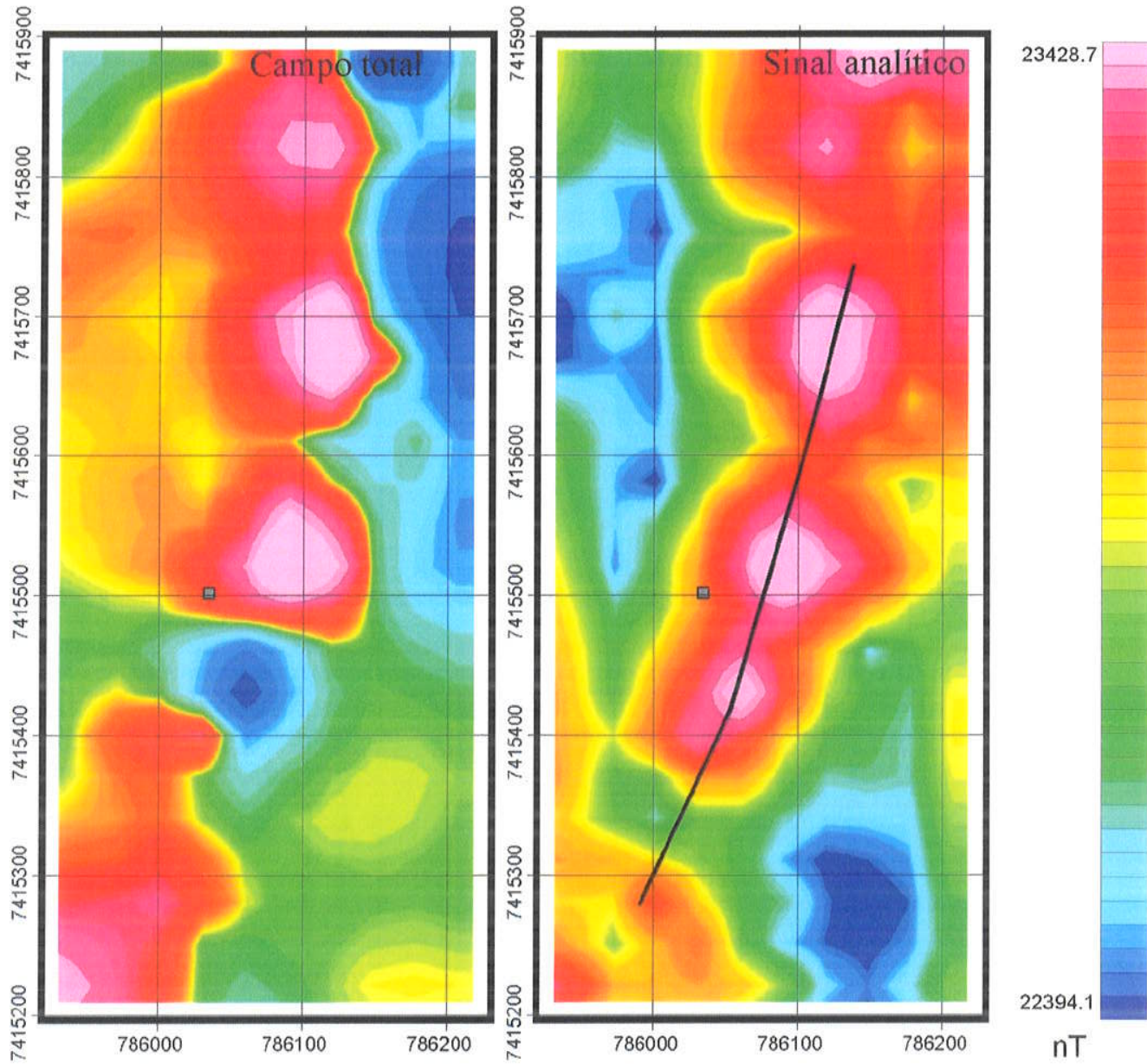

nT

Figura 4.36: Comparação entre campo total e sinal analítico - Nhaíva.

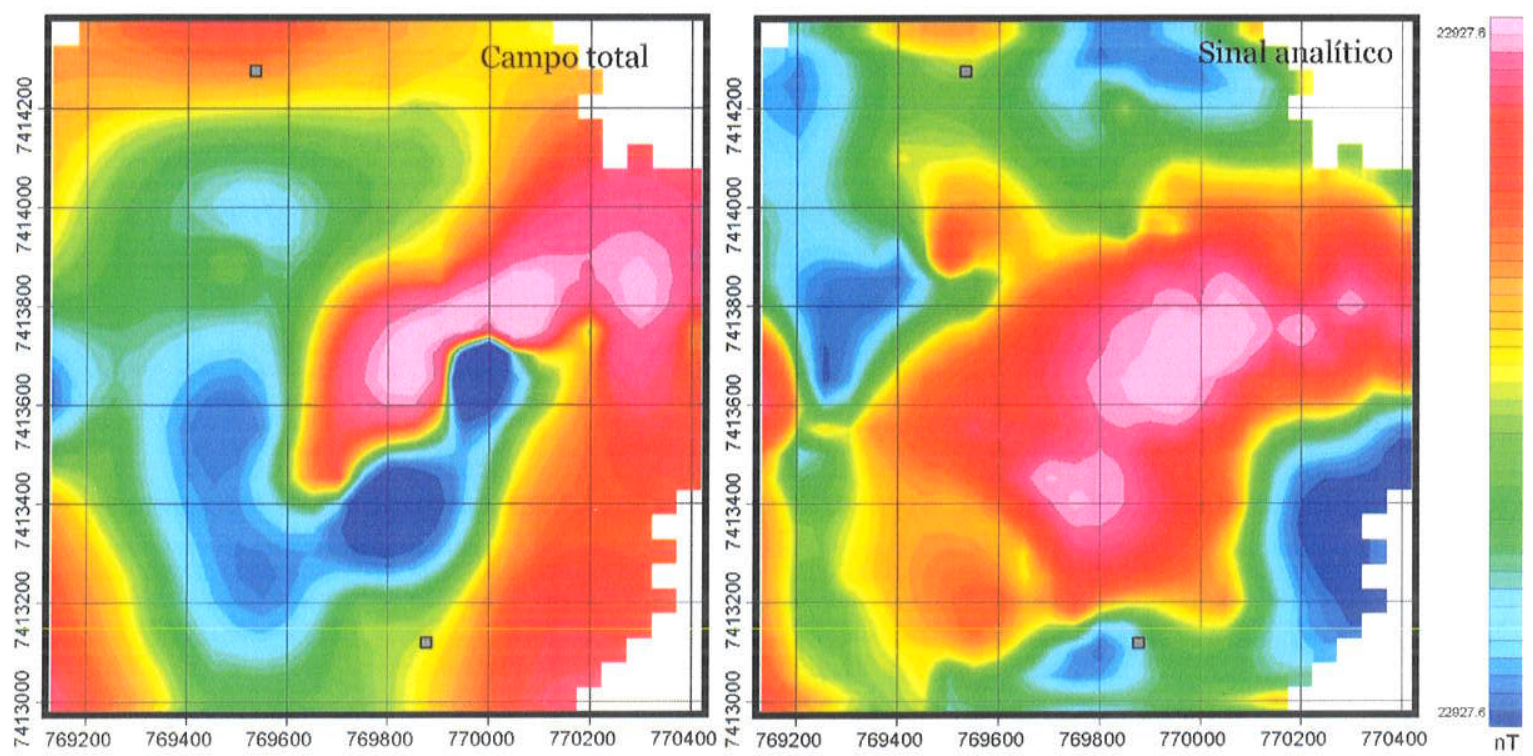

Figura 4.37: Comparação entre campo total e sinal analítico - Sobar. 

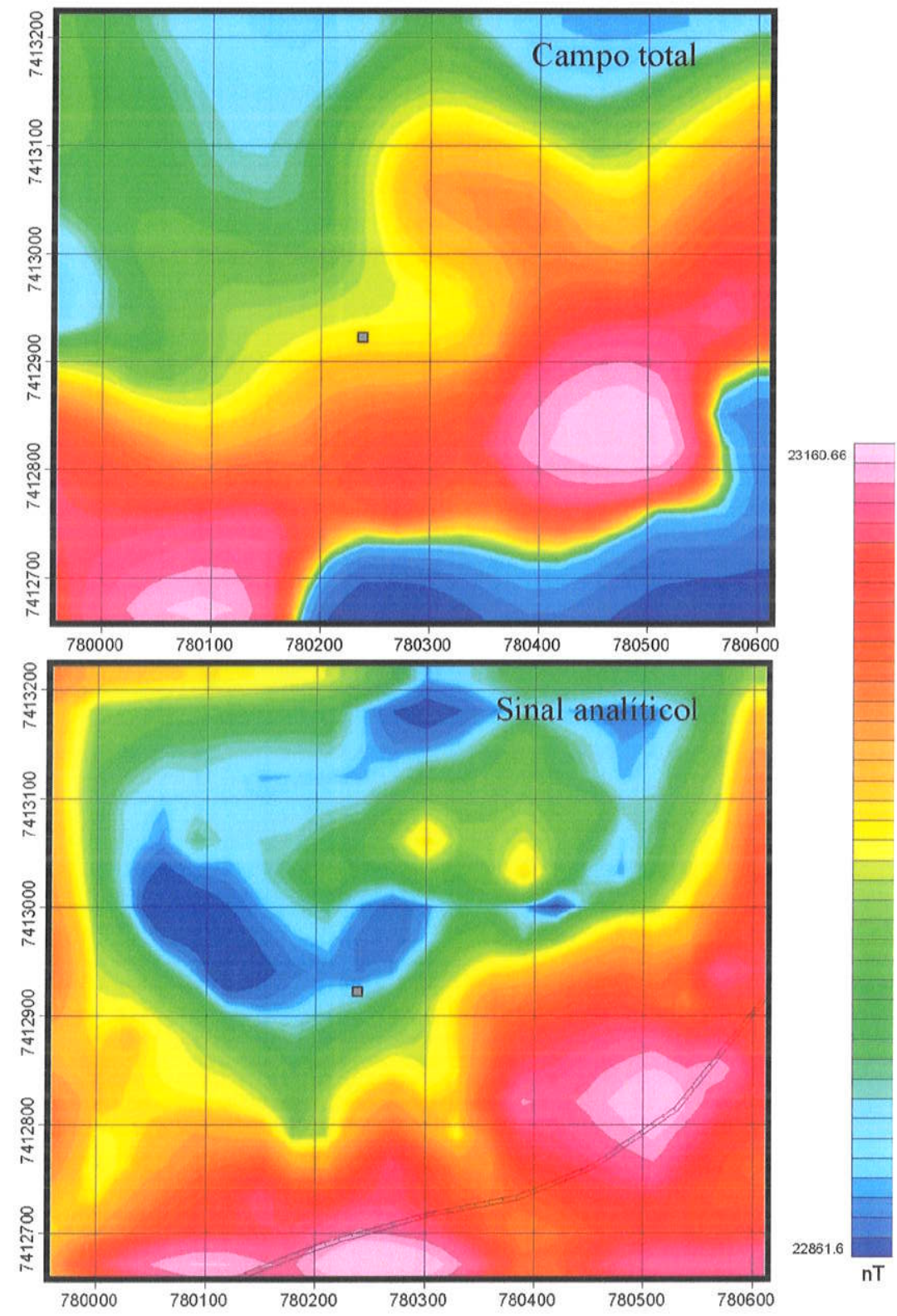

Figura 4.38: Comparação entre campo total e sinal analítico - Itatigue.

4.3 Lineamentos e morfoestruturas da área de estudo

O primeiro passo para a interpretação morfoestrutural e de zonas de juntas nas imagens de sensoriamento remoto foi a digitalização da rede de drenagem de oito cartas topográficas IBGE 1:50.000 (Figura 4.39). Em seguida, utilizando um Sistema de Informação Geográfica (SIG) foi feita a sobreposição dos dados de drenagem com as imagens de satélite. Foram utilizados diversos processamentos para realçar as estruturas, como descritos anteriormente. Em uma primeira fase foi 
complementada a rede de drenagem original. Em seguida, foram retiradas as feições retílineas de drenagem. Finalmente, procedeu-se à interpretação das feições lineares (Figura 4.40) de relevo (positivas) e de drenagem (negativas).

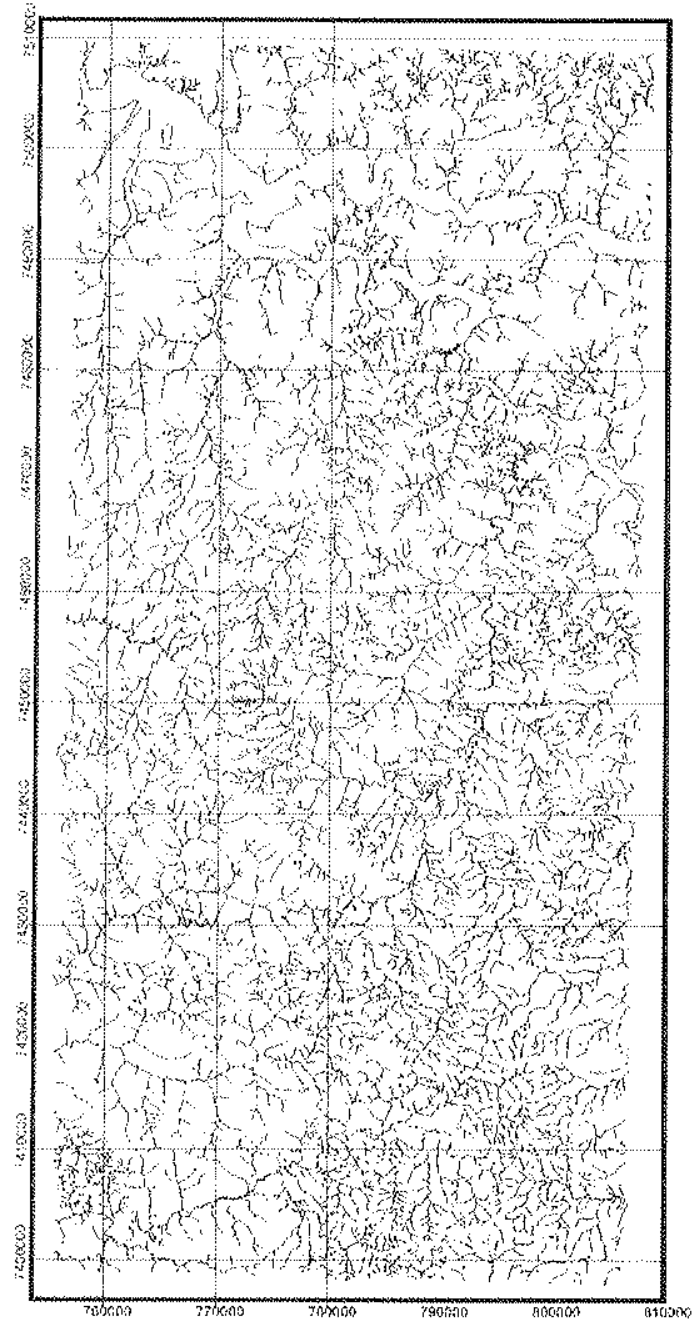

Figura 4.39: Rede de drenagem.

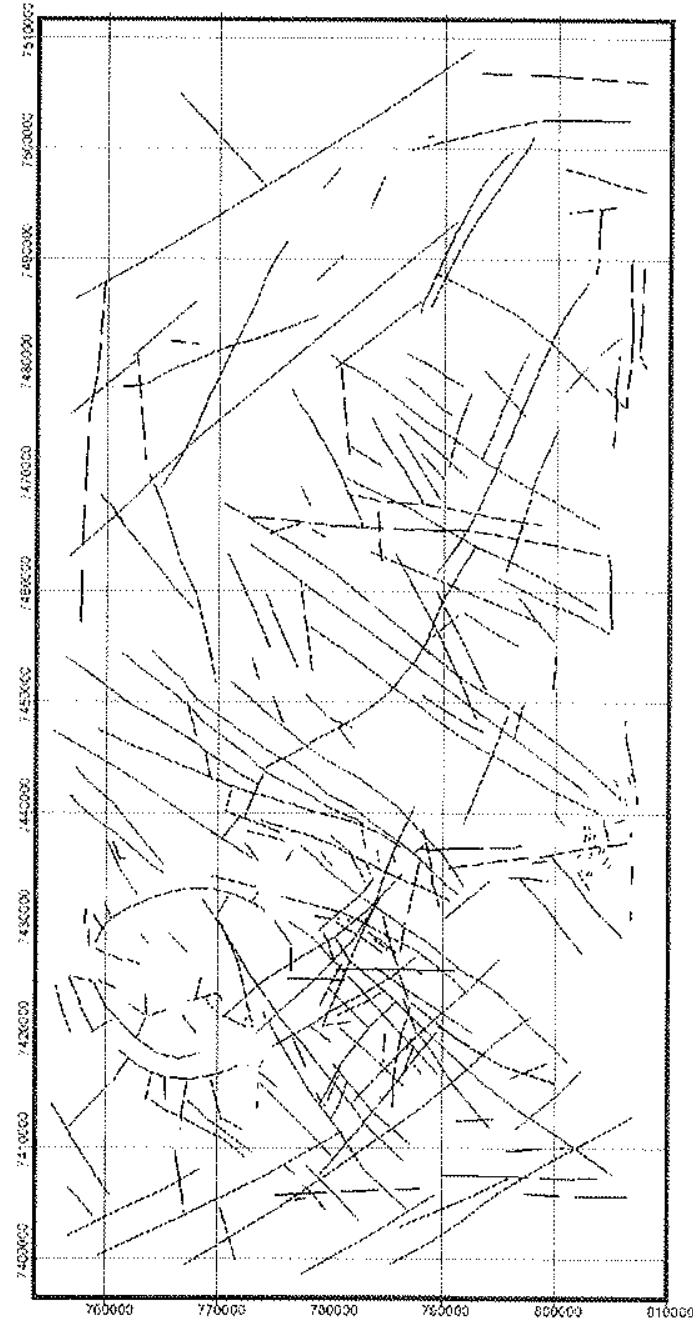

Figura 4.40: Lineamentos interpretados.

A partir das feições anômalas de drenagem, procura-se delinear o comportamento das flexuras do terreno, o que propicia um esboço do comportamento espacial dos altos e baixos estruturais para a área de estudo. Esta interpretação da rede drenagem produz um mapa onde há sobreposição dos efeitos dos diversos eventos tectônicos ocorridos na área ao longo do tempo geológico, mas também traz informações principalmente relacionadas aos últimos eventos. Inicialmente são analisadas feições anômalas de drenagem, que podem indicar altos e baixos estruturais. O comportamento estrutural das camadas sedimentares é interpretado a partir da assimetria de drenagem. Ao se sobrepor os lineamentos interpretados com as anomalias de 
drenagem e traços de camadas procura-se definir o limite entre os blocos altos e baixos. O mapa resultante está na forma de linhas não cotadas representando as flexuras do terreno, de modo que quanto maior a densidade de curvas não cotadas melhor será a definição dos limites entre blocos. Para melhor visualização, estas linhas podem ser interpoladas gerando um modelo numérico de terreno (Figura 4.41).

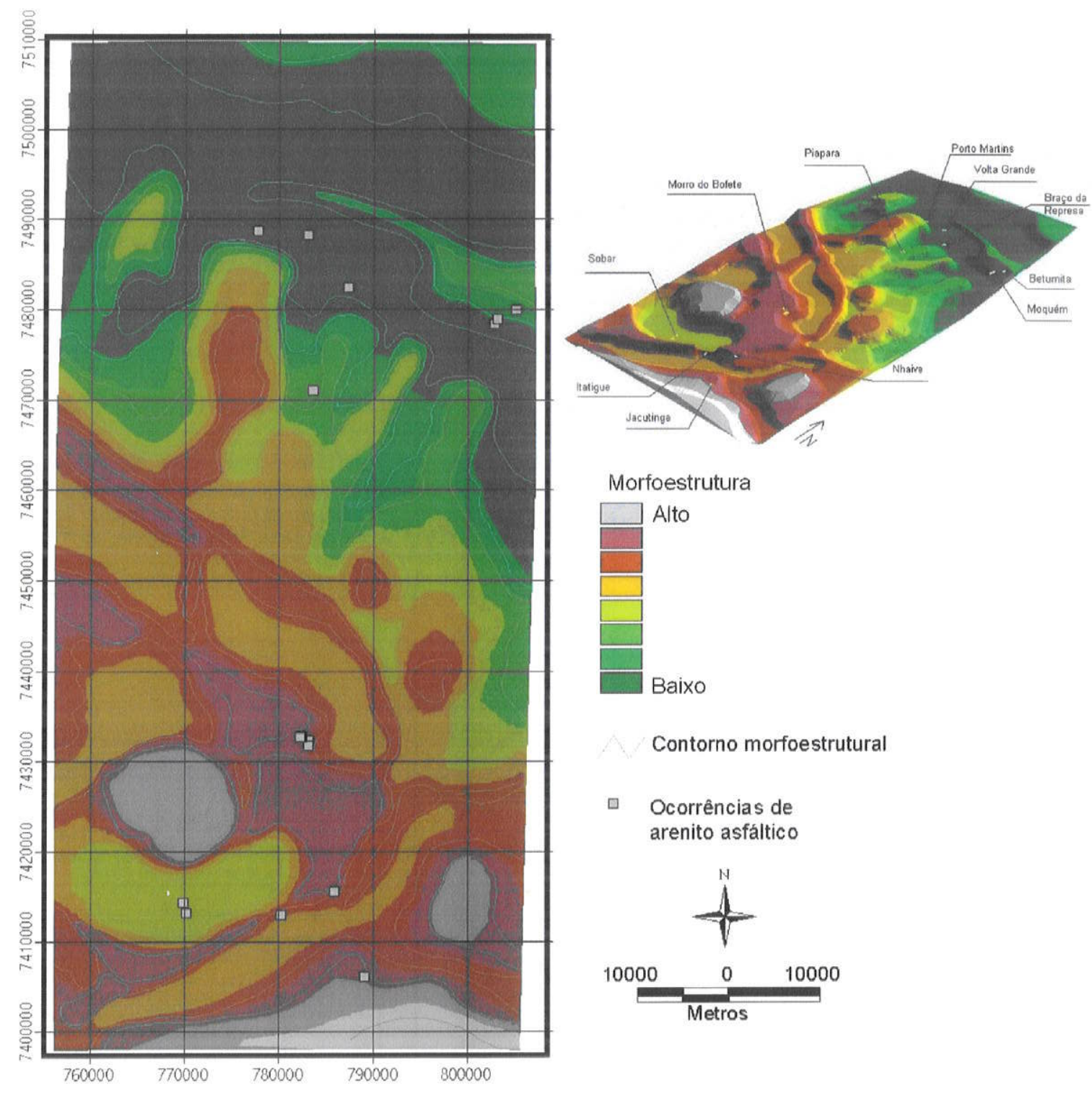

Figura 4.41: Mapa morfoestrutural. Os maiores valores correspondem a altos morfoestruturais, os menores valores correspondem a baixos morfoestruturais.

Em termos regionais, a partir do mapa morfoestrutural, interpreta-se que a região é composta estruturalmente por blocos homoclinais com vergência para o norte. A porção sul da área de estudo, 
estrutura do Jacu, está em posição estrutural mais alta que a porção norte, Alto de Anhembi. A área de estudo é dominada por estruturas NE e NW que se interceptam, gerando altos estruturais/morfoestruturais locais.

Nota-se que a região da estrutura do Jacu é caracterizada pela presença de uma estrutura anelar central, um alto estrutural, circundado por baixos estruturais, ao redor desta "casca de cebola" verifica-se a presença de altos estruturais de direção NW, NS e NE (Figura 4.41). Esta configuração é reconhecível nos mapas gravimétricos e magnetométricos e interpreta-se sua origem como relacionada a disposição das intrusões da Fm. Serra Geral. Contudo, há de se considerar os fenômenos que condicionaram o padrão espacial das intrusões: interação das áreas de fraqueza do embasamento e eventos tectônicos jurássicos que romperam as estruturas anteriores. As ocorrências de arenitos asfálticos na área localizam-se (Figura 4.41), principalmente, nas porções intermediárias entre altos e baixos morfoestruturais. Estas regiões de gradiente morfoestrutural são interpretadas como áreas de limite entre blocos tectônicos onde estão instaladas estruturas relacionadas a áreas de fraqueza como as falhas e intrusões básicas.

$\mathrm{Na}$ região do Alto de Anhembi nota-se a configuração de estruturas de direção NE (altos e baixos morfoestruturais) na região de Piapara e de direção NW (baixo morfoestrutural) na região da Represa de Barra Bonita (Figura 4.41). Notou-se a partir de fotos aéreas e de imagens de sensoriamento remoto, que algumas ocorrências na área também estão relacionadas a morfoestruturas, localizadas precisamente em regiões intermediárias entre altos e baixos estruturais. Entretanto, esta observação não é clara no mapa morfoestrutural produzido devido ao relevo arrasado em parte da região e a geologia Terciária (Figura 4.41) que obliterou a interpretação relacionada principalmente a fenômenos mais antigos.

\subsection{Zonas de juntas}

$\mathrm{Na}$ interpretação consideraram-se os trechos retilíneos de canais de drenagem como elementos de interesse, já que as drenagens estabelecem-se preferencialmente sobre as linhas susceptíveis à maior erodibilidade, como as zonas de juntas e fraturas.

Utilizou-se um comprimento mínimo do traço igual a $3 \mathrm{~mm}$, para interpretação de feição retilinea na escala 1:250.000, o que equivale a $750 \mathrm{~m}$. Este valor visou a interpretação regional das zonas de fraturamento (Figura 4.42). 

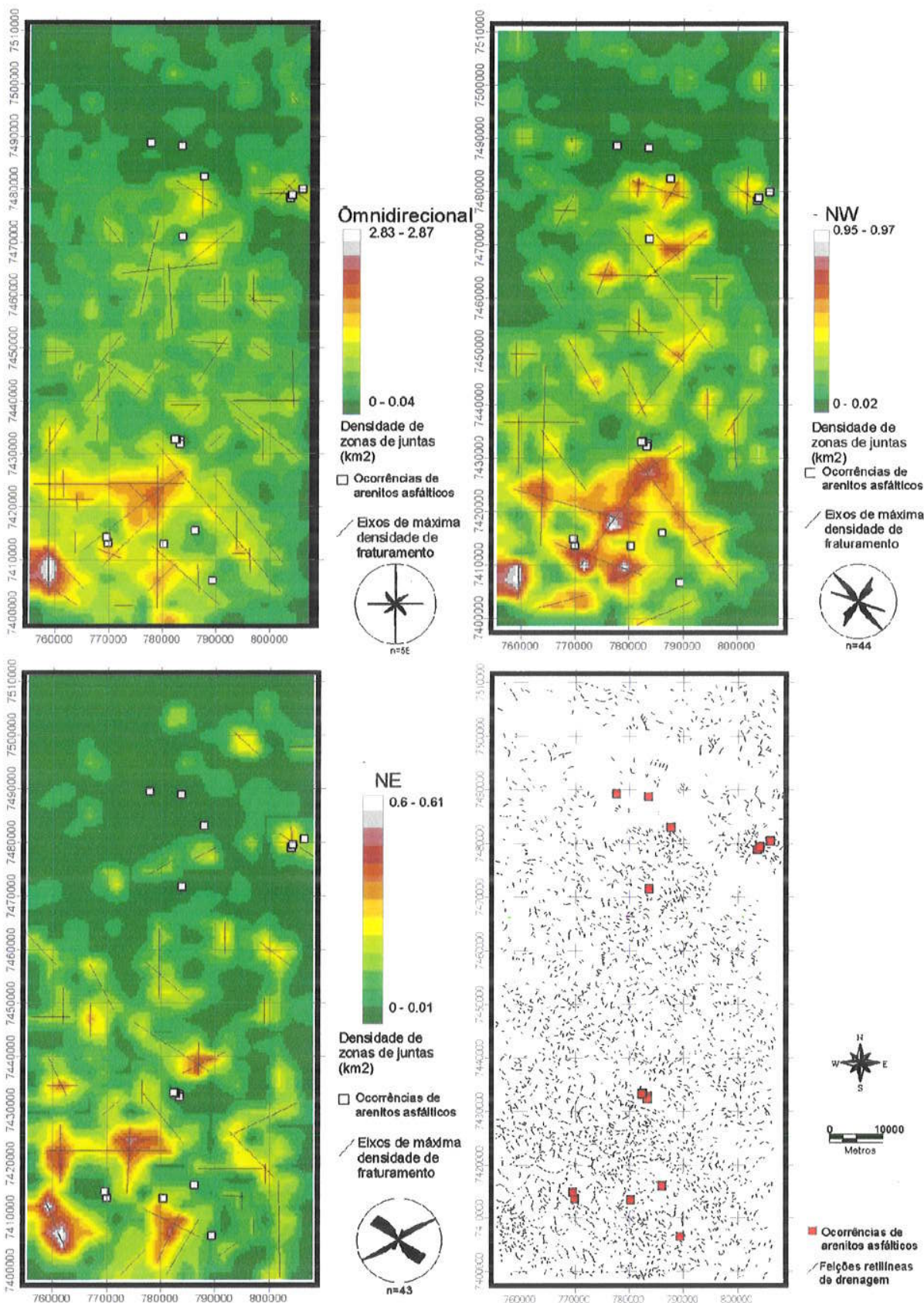

Figura 4.42: Feições retilíneas de drenagem interpretadas e mapas de densidade.

Analisou-se a freqüência de traços por área. O método de cálculo desta freqüência é baseado na contagem do número de traços em uma grade regular de amostragem, considerando-se os traços como aproximadamente padronizados em um mesmo comprimento. Segundo Beisl (1996), a grade regular de amostragem pode ser definida a partir do comprimento médio e desvio padrão das feições lineares extraídas das drenagens, neste caso o valor foi de $539 \pm 154 \mathrm{~m}$. Deste modo, a grade regular de amostragem poderia ter um valor de $700 \mathrm{~m}$. Contudo, este tamanho de grade mostrou-se 
inadequado para representar as diferenças de densidade de fraturamento. Assim, optou-se por aplicar diversos tamanhos de grade de amostragem, visando-se definir, empiricamente, o melhor tamanho de grade para a interpretação visual posterior. Utilizaram-se grades de 1500, 2000, 2500, $3000,4000 \mathrm{~m}$ de lado, das quais a grade de $2500 \mathrm{~m}$ apresentou o melhor resultado. Para melhorar o aspecto final foi feita uma reamostragem para uma grade de $500 \mathrm{~m}$. Deste modo, foi gerado um mapa de densidade de zonas de juntas omnidirecional (Figura 4.42).

A partir da roseta dos traços levantados, definiram-se duas direções preferenciais de zonas de juntas que são as seguintes: N45E e N45W. A partir destas direções, foi aplicada uma tolerância angular de $45^{\circ}$ graus. Assim, foram gerados mapas de densidade de zonas de juntas NW e NE (Figura 4.42) segundo o método explicado anteriormente.

Conforme a metodologia apresentada por Crepani (1987), na análise dos mapas de isofreqüência, consideram-se as seguintes observações:

- a quantidade de zonas de juntas aumenta em relação à proximidade de falhas, indicando uma associação genética e geométrica entre as falhas e os conjuntos de zonas de juntas;

- lineamentos antigos tendem a condicionar a freqüência das zonas de juntas formadas em regiões submetidas a processos de reativação.

Segundo Crepani (1987), o eixo maior das figuras elípticas presentes nas curvas de isofreqüência de densidades máximas de zonas de juntas é uma evidência da presença de linhas de fraqueza da crosta no local. Santos (1986) justifica a utilização do tratamento estatístico dos dados de fraturamento baseado na premissa de que uma fratura é uma zona de fraqueza e, portanto, uma zona potencial no condicionamento da distribuição dos eventos rupturais posteriores que afetaram a região. Deste modo, a análise das principais direções de fraturamento pode indicar as principais zonas de fraqueza, que condicionaram o desenvolvimento tectônico posterior afetando a região (Figura 4.42).

Em termos regionais, nota-se que a maior densidade de zonas de juntas localiza-se na porção sul da área de estudo. Esta disposição pode ser interpretada como resultante da ampla cobertura geológica Terciária presente na região da represa de Barra Bonita, que oblitera a interpretação de feições retilineas de drenagem. Além disso, esta cobertura Terciária tem distribuição restrita na porção sul. Finalmente, interpreta-se que a porção sudoeste da área de estudo foi mais afetada pela tectônica do Arco de Ponta Grossa, havendo uma diminuição deste fenômeno para o norte.

A Zona de Falha de Jacutinga, alinhamento do Tietê e alinhamento Barra Bonita-Itu têm respostas tênues no mapa de densidade de zonas de juntas, na forma de valores médios a altos de densidade alinhados NE. Já a região do Domo de Carlota Prenz, Soleira de Angatuba e Falha do Rio Guarei apresentam padrões de alta densidade de zonas de juntas. Deste modo, a região sul da área 
de estudo é caracterizada por um domínio de altos valores de densidade, reflexo da tectônica JuroCretácea na forma de falhas e intrusões de rochas básicas.

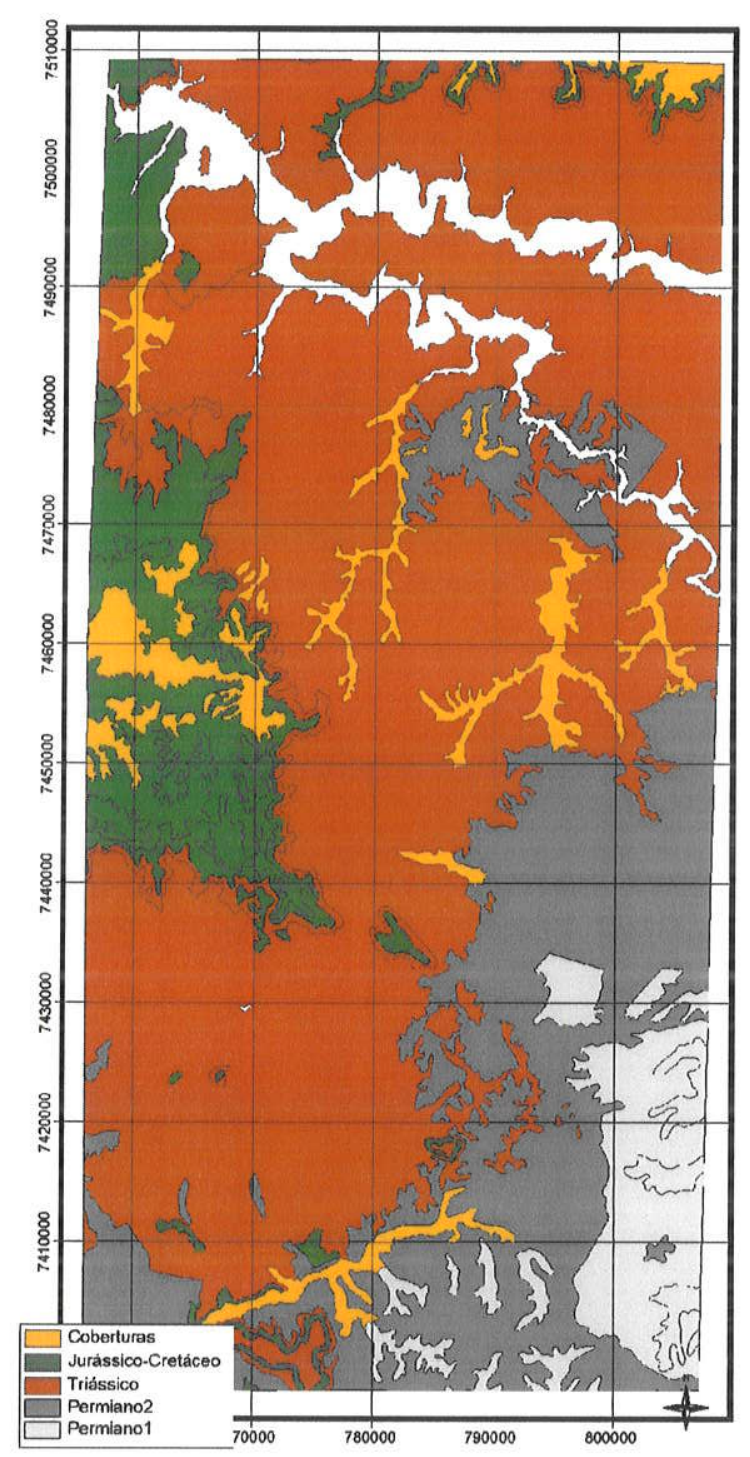

Figura 4.43: Mapa com divisão estratigráfica utilizada para separação de juntas.

Em relação às ocorrências de arenitos asfálticos, nota-se, de modo geral, que estas localizamse em regiões de valores intermediários a altos de densidade de zonas de juntas (Tabela 8). Esta característica é claramente observada na porção sul da área de estudo, donde pode-se relacionar a maior densidade à intrusão de rochas básicas e falhamentos com conseqüente disposição de ocorrências de arenitos asfálticos. As ocorrências não localizam-se diretamente sobre as áreas de alto valor de densidade, seja por questões geomorfológicas, seja por questões geológicas. Interpretase que as áreas mais fraturadas têm maior probabilidade de ter ocorrências; entretanto, também são áreas mais dissecadas. Além disso, as áreas mais fraturadas sofreram intrusões ígneas. Conclui-se 
que as ocorrências de arenitos asfálticos localizam-se nas regiões onde concorrem condições ótimas de migração e acumulação, mas também de preservação em relação à denudação dos terrenos geomorfológicos.

Tabela 8: Ocorrências de arenitos asfálticos e valores de densidade de zonas de junta.

\begin{tabular}{|l|c|c|c|}
\hline Ocorrência & Omnidirecional & NW & NE \\
\hline Valor médio na área de estudo & 0.56 & 0.21 & 0.10 \\
\hline Volta Grande & 0.05 & 0.04 & 0.00 \\
\hline Porto Martins & 0.07 & 0.03 & 0.00 \\
\hline Piapara & 0.31 & 0.38 & 0.03 \\
\hline Morro do Bofete & 0.36 & 0.19 & 0.03 \\
\hline Fazenda São Jorge & 0.42 & 0.20 & 0.02 \\
\hline Estrada da Mina & 0.44 & 0.19 & 0.05 \\
\hline Estrada da Mina II & 0.44 & 0.19 & 0.05 \\
\hline Nhaiva & 0.46 & 0.25 & 0.11 \\
\hline Bairro da Mina & 0.56 & 0.21 & 0.05 \\
\hline Bairro da Mina II & 0.56 & 0.21 & 0.05 \\
\hline Jacutinga & 0.60 & 0.17 & 0.10 \\
\hline Braço da Represa & 0.69 & 0.43 & 0.00 \\
\hline Moquém & 0.81 & 0.28 & 0.22 \\
\hline Moquém II & 0.91 & 0.28 & 0.26 \\
\hline Itatigue & 0.91 & 0.42 & 0.25 \\
\hline Betumita & 0.97 & 0.16 & 0.18 \\
\hline Sobar II & 1.02 & 0.38 & 0.04 \\
\hline Sobar & 1.19 & 0.51 & 0.09 \\
\hline
\end{tabular}

Obs: Densidade de zonas de juntas: ocorrências $/ \mathrm{Km}^{2}$.

A partir do conjunto total das zonas de juntas, foi feita uma separação baseada na estratigrafia regional da área. Esta separação teve como objetivo a pesquisa de fraturas associadas a eventos geológicos relacionados a diversos períodos. Dessa forma, utilizou-se o mapa geológico compilado de DAEE/UNESP (1984) na escala 1:250.000 para a separação das áreas de afloramentos de rochas do Permiano ao Quaternário. A separação das zonas de juntas foi feita segundo diferentes tipos litológicos/estratigráficos como pode ser visto na Tabela 9 e Figura 4.43.

Tabela 9: Tipos litoestratigráficos utilizados na separação das zonas de juntas.

\begin{tabular}{|l|l|}
\hline $\begin{array}{l}\text { Litoestratigrafia } \\
\text { Depósitos de cimeira, Fm. Rio Claro, Colúvios, } \\
\text { aluviões }\end{array}$ & Coberturas \\
\hline Suítes Básicas, Fm. Serra Geral, Fm. Marília & Jurássico/Cretáceo \\
\hline Fm. Pirambóia, Fm. Botucatu & Triássico \\
\hline Fm. Teresina & Permiano 2 \\
\hline Subgrupo Irati, Fm. Tatuí & Permiano 1 \\
\hline
\end{tabular}


O resultado desta separação de zonas de juntas por período geológico pode ser observado nas figuras onde apresentam-se as rosetas (Figura 4.44 e Figura 4.45) e na Tabela 10.

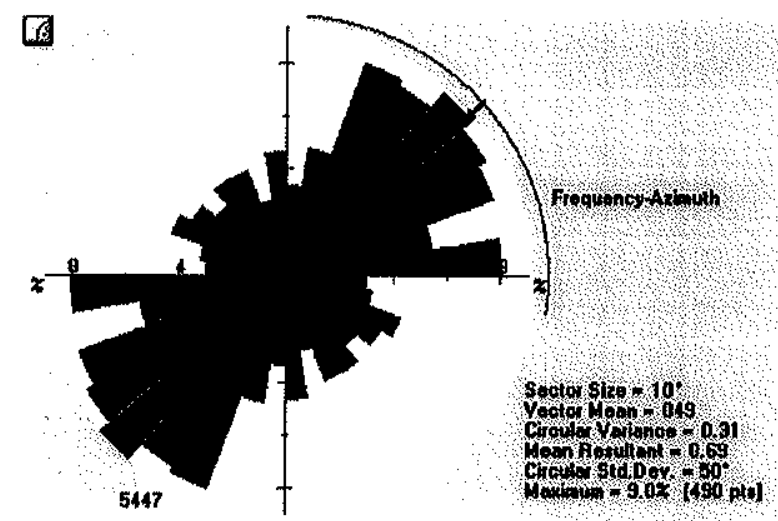

A: Roseta do conjunto total de feições retilineas de drenagem de toda área de estudo.

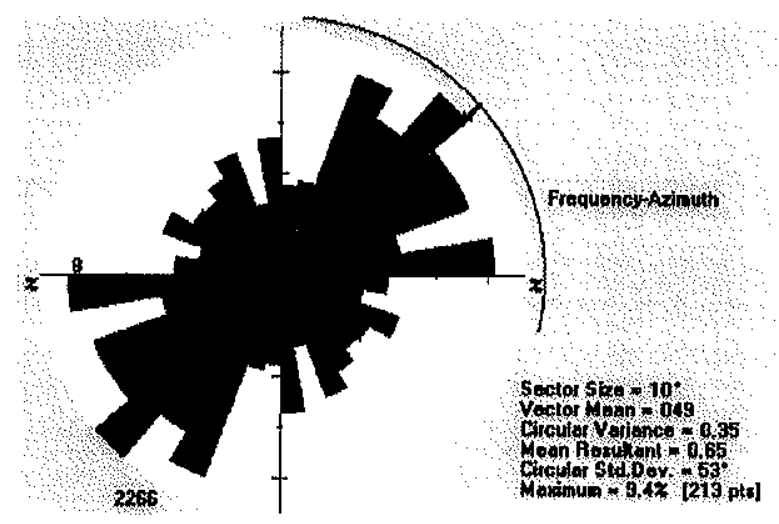

B: Roseta do conjunto total de feições retilíneas de drenagem da porção sul da área de estudo.

Figura 4.44: Roseta do conjunto total de feições retilíneas de drenagem.

Devido à singularidade do padrão de densidade da região sul da área de estudo, optou-se por separar as feições retilíneas de drenagem desta área, gerar uma roseta separadamente e comparar com a roseta da área total (Figura 4.44A e B). Verificou-se que não há diferença no padrão de zonas de juntas da região sul em relação a toda área de estudo.

Tabela 10: Feições lineares de drenagem por período geológico.

\begin{tabular}{|l|c|c|}
\hline Nome da classe & Vetor médio & $\begin{array}{l}\text { Desvio Padrão } \\
\text { (angular) }\end{array}$ \\
\hline Coberturas & 144 & 51 \\
\hline Jurássico/Cretáceo & 139 & 48 \\
\hline Triássico & 135 & 49 \\
\hline Permiano 2 & 137 & 50 \\
\hline Permiano 1 & 22 & 81 \\
\hline
\end{tabular}




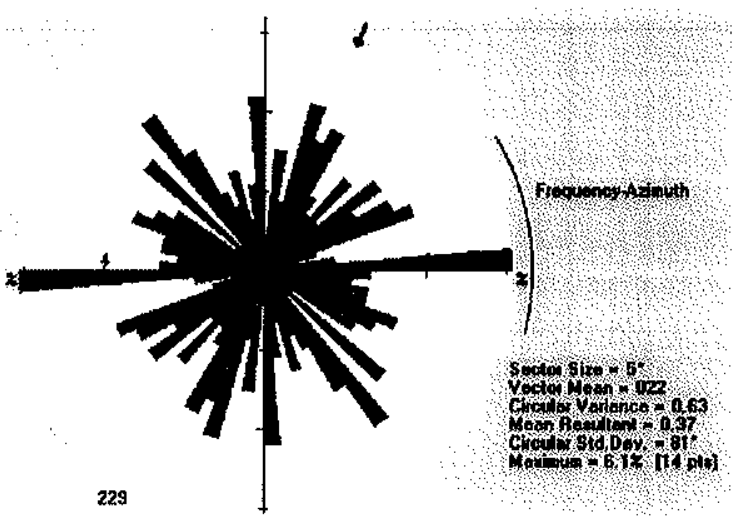

A: Roseta das feições retilíneas de drenagem em áreas de afloramento de rochas Permianas.

(Subgrupo Irati e Tatui - Permiano 1)

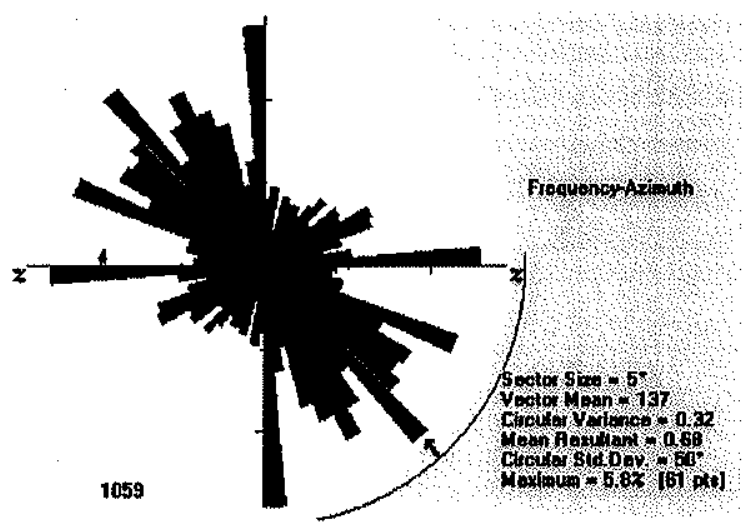

B: Roseta das feições retilíneas de drenagem em áreas de afloramento de rochas Permianas.

(Fm. Teresina - Permiano 2)

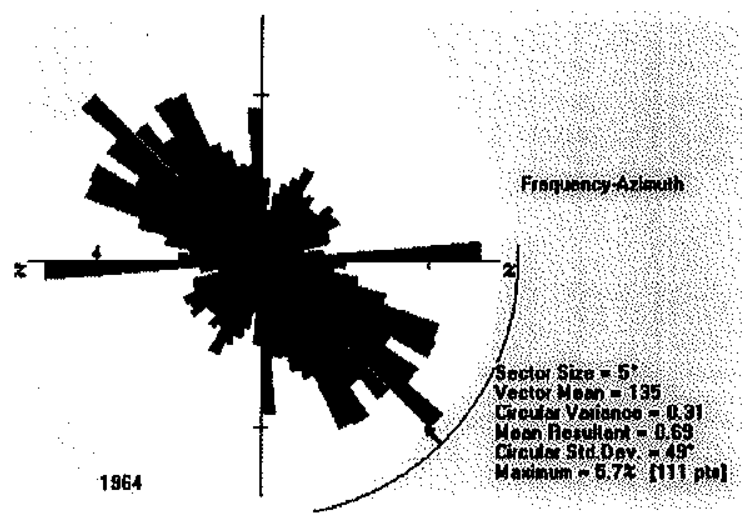

C: Roseta das feições retilíneas de drenagem em áreas de afloramento de rochas Triássicas.

(Pirambóia/Botucatu)

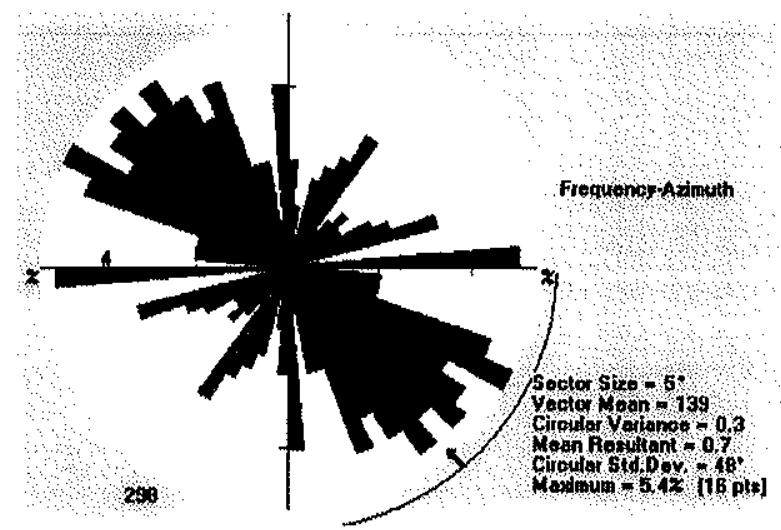

D: Roseta das feições retilíneas de drenagem em áreas de afloramento de rochas Juro-Cretáceas.

(Fm. Serra Geral/Fm.Marília)

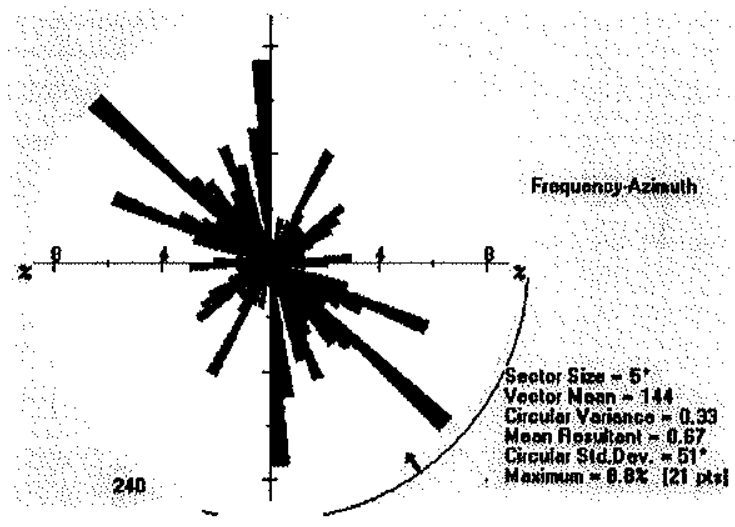

E: Roseta das feições retilíneas de drenagem em áreas de afloramento de coberturas sedimentares recentes.

Figura 4.45: Rosetas de feições retilíneas de drenagem por período geológico. 
As rosetas das feições de rochas Permianas (Figura 4.45A) demonstra o acúmulo de estruturas ao longo do tempo geológico. Ao final do Permiano (Figura 4.45B) é possível, apesar dos ruídos nos dados, verificar a presença marcante de estruturas NW assim como ao longo do Triássico (Figura 4.45C) e Jurássico-Cretáceo (Figura 4.45D). Apesar do predomínio da direção NW nestas rosetas (Tabela 10), este predomínio demonstra que os fenômenos tectônicos do Permiano ao JuroCretáceo sobrepujaram as tensões de confinamento e extravasaram as áreas de fraqueza condicionadas pela geologia do embasamento. Entretanto, não é desprezível a alta freqüência de estruturas NE que em conjunto com os eixos de máxima freqüência de fraturamento demonstra o papel condicionante das estruturas do embasamento, principalmente quando se observa a roseta do início do Permiano (Figura 4.45a) e de toda a área de estudo (Figura 4.44a).

\subsection{Contorno estrutural}

Uma das características das ocorrências de arenitos asfálticos relacionamse a seu posicionamento na base da Formação Pirambóia, estratigraficamente próxima da Fm. Teresina. Assim, o entendimento do comportamento estrutural da Fm. Teresina é fator importante no estudo das ocorrências de arenitos asfálticos. Esta característica pode ser observada regionalmente no mapa preliminar de contorno estrutural (Figura 4.46) e em dados de campo. No mapa de contorno estrutural observam-se as ocorrências associadas principalmente às áreas de altos estruturais como as ocorrências Sobar, Nhaiva e Morro do Bofete.

A geração de um mapa de contorno estrutural na área de estudo envolveu basicamente a utilização de um mapa disponivel no Relatório DEXPRO 401 (Petrobrás 1971 apud Franzinelli (1972) e levantamento da posição espacial dos contatos entre a Formação Pirambóia e a Formação Pirambóia, a partir de trabalhos de campo. A cota dos contatos foi levantada utilizando mapas topográficos na escala 1:10.000 do Instituto Geográfico e Cartográfico do Estado de São Paulo. 


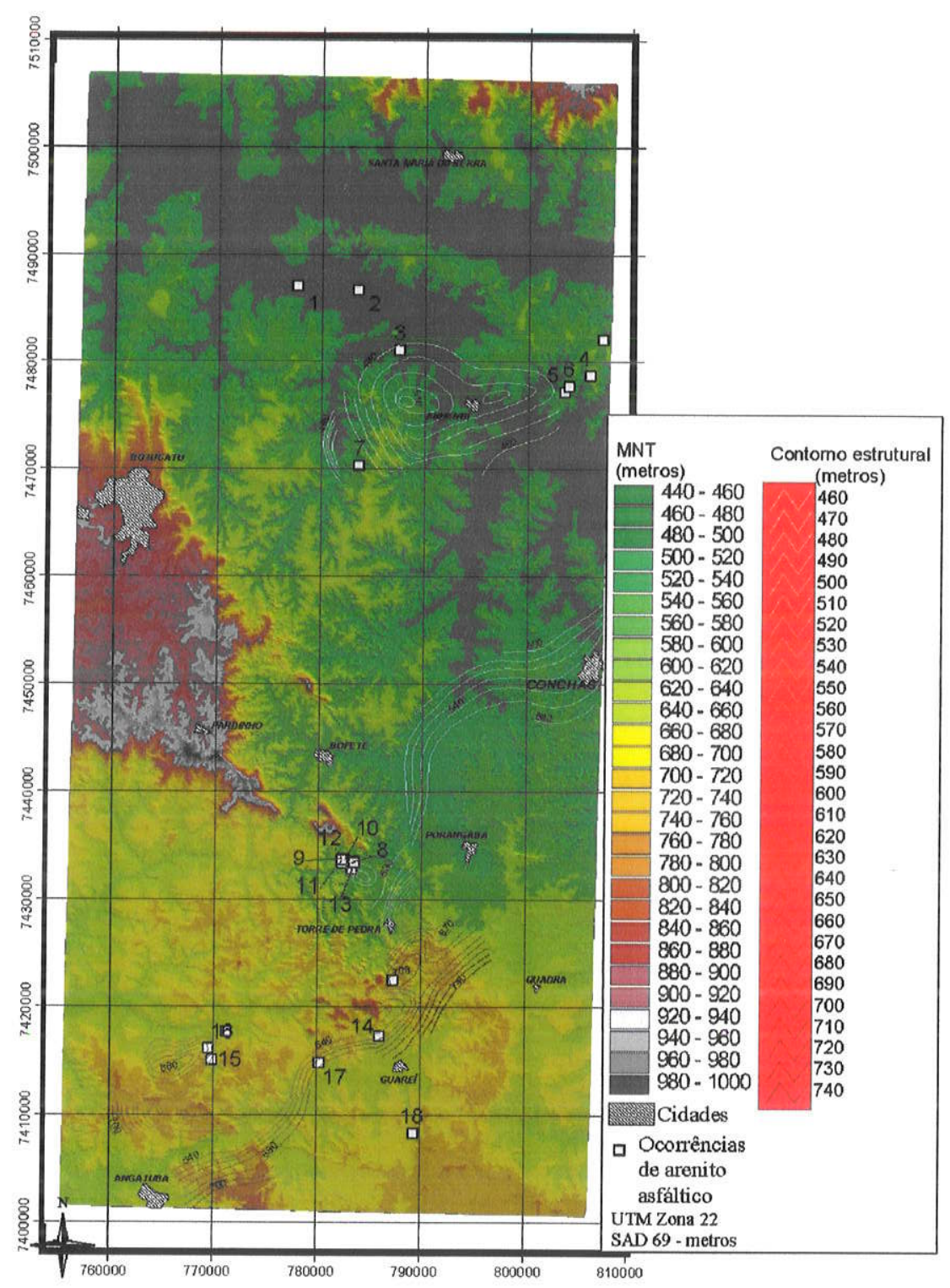

Figura 4.46: Contorno estrutural (Fm. Teresina). Ocorrências: 1 - Porto Martins; 2 - Volta Grande; 3 - Braço da Represa; 4 - Betumita; 5 - Moquém I; 6 - Moquém II; 7 - Piapara; 8 - Morro do Bofete; 9 - Fazenda São Jorge; 10 - Estrada da Mina; 11 - Bairro da Mina; 12 - Bairro da Mina II; 13 - Estrada da Mina II; 14 - Nhaíva; 15 - Sobar; 16 - Sobar II; 17 - Itatigue; 18 - Jacutinga.

O mapa de contorno estrutural da Petrobrás foi digitalizado e georreferenciado. A interpretação dos pontos de contato cotados foi feita em um Sistema de Informação Geográfica, onde foi possível, interativamente, observar os pontos levantados em campo e os dados bibliográficos. Notou-se incompatibilidade de valores entre alguns pontos levantados em campo e os dados da Petrobrás. Atribui-se estas discrepâncias a possíveis problemas com calibração de altímetro no levantamento da Petrobrás. 
Regionalmente, o mapa de contorno estrutural da Fm. Teresina confirma as estruturas, interpretadas no mapa morfoestrutural (Figura 4.41), da porção sul da área como estruturalmente mais altas que as da parte norte. O fechamento das estruturas na área do Alto de Carlota Prenz ocorre na cota topográfica 660 chegando a $700 \mathrm{~m}$ na porção sul. Já o Alto de Anhembi tem a cota topográfica 510 como mais alta. Estas estruturas têm, em geral, configuração elíptica com eixo maior de direção NE. O mergulho principal das camadas é para NW. Esta configuração confirma o conceito de estruturas do embasamento NE que condicionam as estruturas NW geradas pela Reativação PósPaleozóica.

As ocorrências de arenito asfáltico distribuem-se, à exceção da ocorrência Jacutinga, sempre na borda dos altos estruturais. As ocorrências de Porto Martins, Volta Grande e Braço da Represa estariam aparentemente distantes do Alto Estrutural de Anhembi (Figura 4.46). Entretanto, dados de campo demonstraram a presença de coberturas sedimentares Terciárias distribuídas amplamente por toda aquela área que podem encobrir os contatos geológicos. Além disso, a ocorrência Braço da Represa encontra-se próxima a um alto morfoestrutural detectado em fotografia aérea e que pode estar relacionado a uma extensão do Alto Estrutural de Anhembi.

O mapa de contorno estrutural da Fm. Teresina configura-se como elemento chave na detecção de áreas favoráveis à ocorrência de arenito asfáltico. A posição estratigráfica das ocorrências na base da Fm. Pirambóia e estrutural junto a altos estruturais indica que o modelo de migração para as ocorrências tem um forte componente estrutural relacionado à borda de blocos tectônicos e zonas de falhas.

\subsection{Tectonismo deformador na área de ocorrência de arenito asfáltico}

\subsection{1 Área da estrutura do Jacu}

$\mathrm{Na}$ área de estudo há evidencias de pelo menos dois eventos deformacionais Mesozóicos com características pós-deposicionais. As estruturas mais freqüentes encontradas nos arenitos reservatório correspondem a descontinuidades rúpteis. Várias zonas de junta diferentes são encontradas na área. Fraturas e bandas de deformação (Aydin, 1978) ocorrem com ângulos de mergutho maiores que $75^{\circ}$. Observando os diagramas de rosetas de lineamentos e falhas (Figura 4.47) é possivel determinar duas famílias principais de fraturamento na área, NE e NW. Optou-se por representar os dados de fraturamento na forma de rosetas devido ao ângulo de mergulho dos planos maior que $80^{\circ}$. Estas juntas correspondem a fraturas secundárias relacionadas aos diferentes eventos rúpteis superimpostos, um mais antigo NE e um mais jovem NW. Somente em alguns afloramentos é possível observar indicadores cinemáticos (Figura 4.48A e B). 


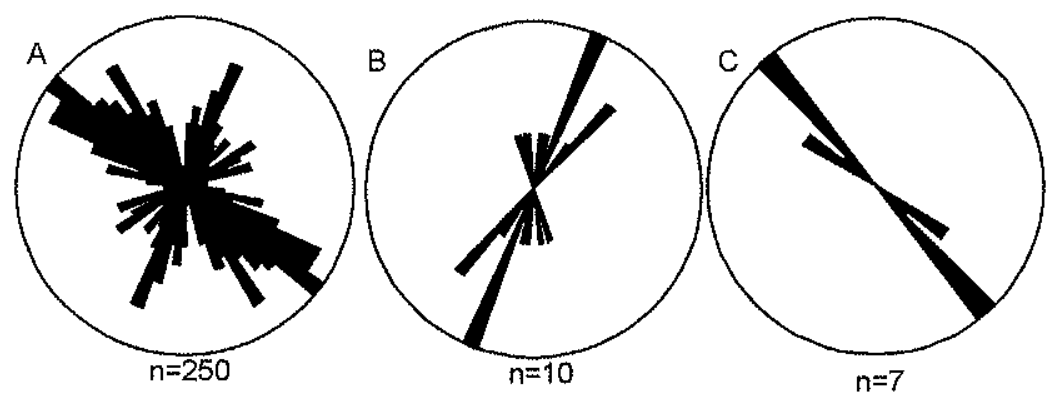

Figura 4.47: Rosetas de falhas. (A) Roseta dos lineamento interpretados em imagens de satélite e MNT; (B) Falhas NE sinistrais; (C) Falhas NW dextrais.

A

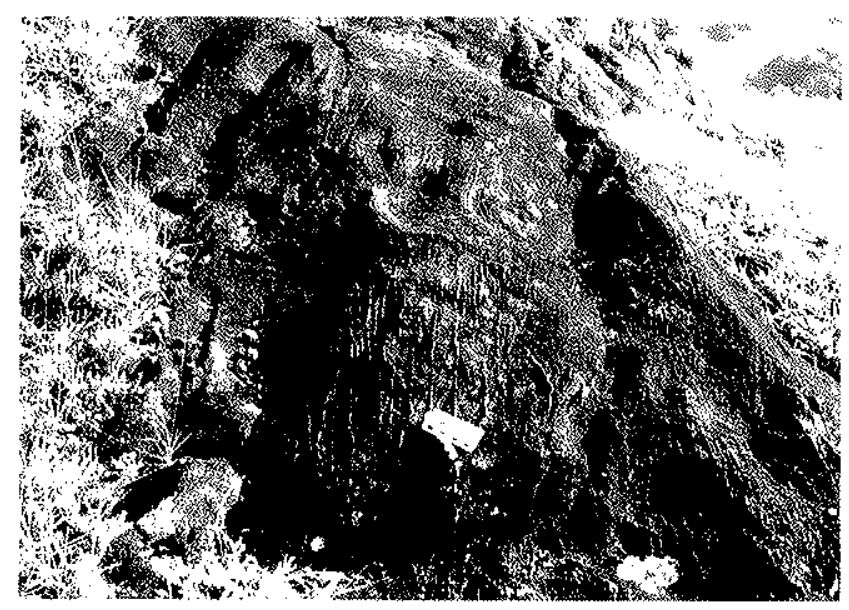

B

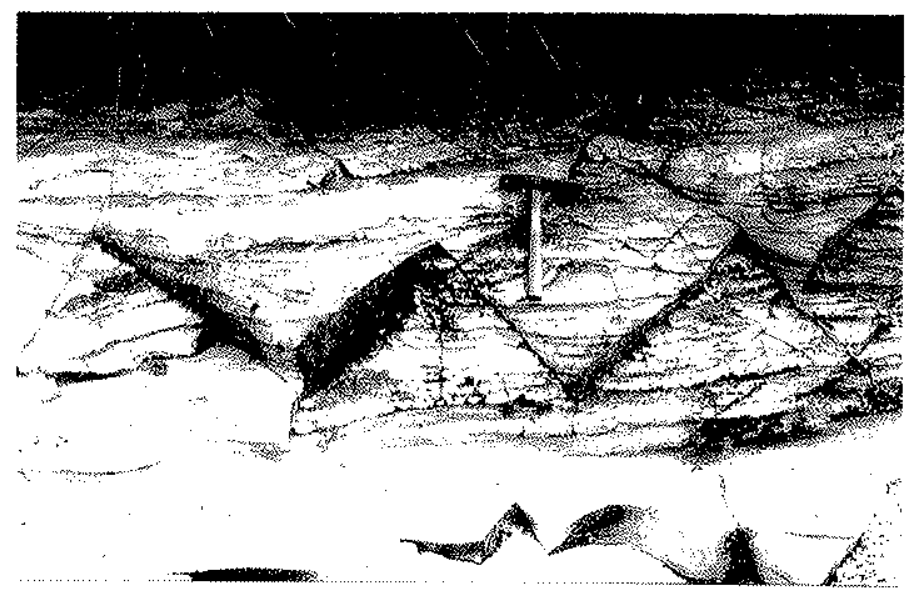

Figura 4.48: Exemplos de indicadores cinemáticos. (a) Bandas de deformação; (b) Fraturamento.

Lineamentos interpretados em imagens de sensoriamento remoto e em modelos numéricos de terreno indicam direções principais $\mathrm{N} 50 \mathrm{~W}$ e N10-30E como as principais. Alguns lineamentos menores têm direção EW.

Em campo, indicadores cinemáticos foram interpretados em bandas de deformação (Figura 4.48A) e fraturas escalonadas riedel/anti-riedel (Figura 4.48B). Entretanto, tais indicadores têm baixo nível de confiabilidade, foram encontradas estrias em apenas um afloramento da Fm. Teresina onde havia um pequeno horst (Figura 4.51B). Interpreta-se que a área é caracterizada principalmente por falhas de gravidade com pequeno componente direcional, classificadas então como falhas oblíquas. Em campo, foi possível observar falhas oblíquas sinistrais N30-40E como interpretado nas imagens de sensoriamento remoto, MNT e rede de drenagem (Figura 4.49). Algumas falhas NE estão associadas com diques de rochas básicas (área da ocorrência Morro do Bofete). 


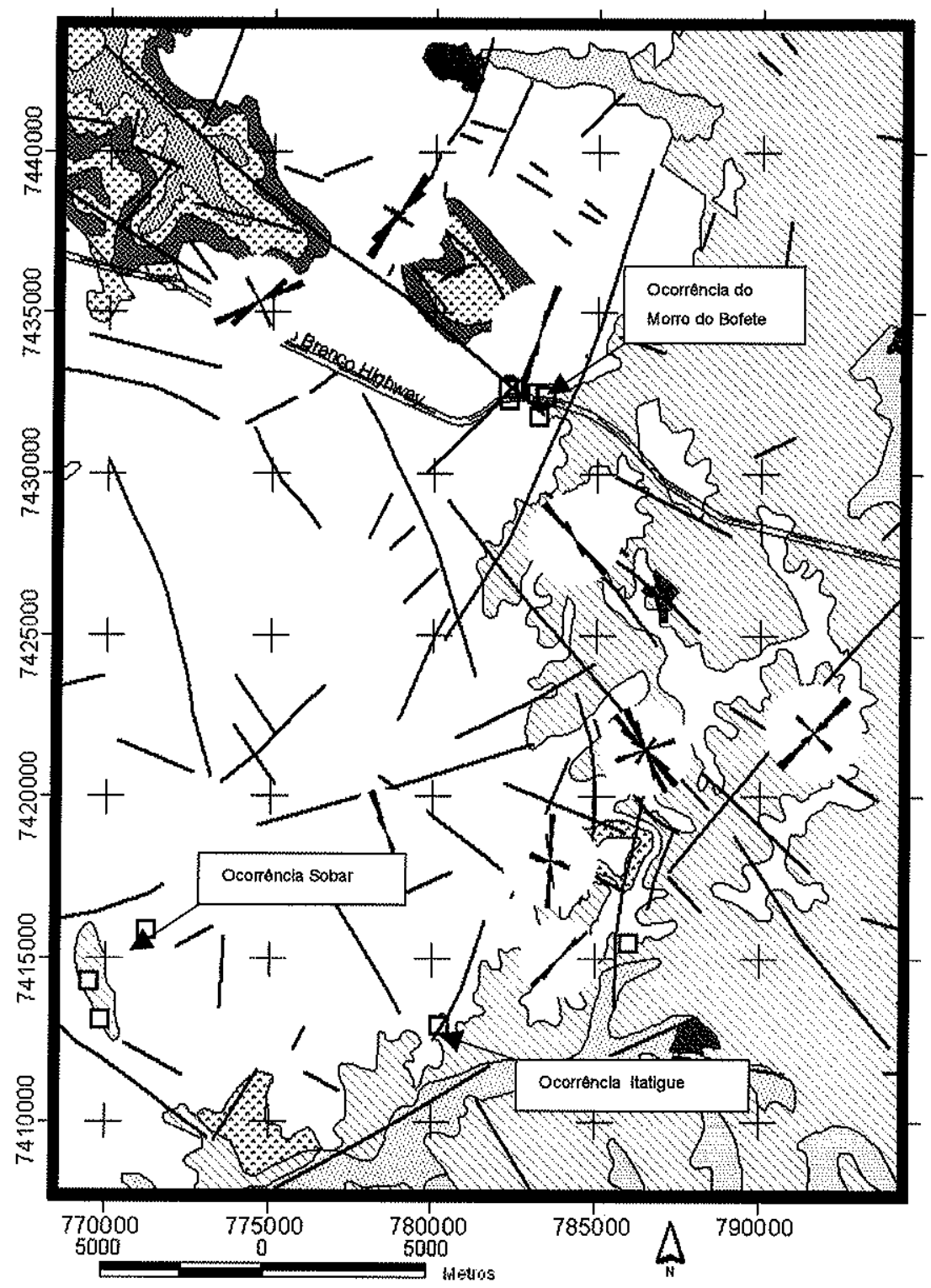

Figura 4.49: Lineamentos interpretados e rosetas de sistemas de fraturamento na área da estrutura do Jacu.

As falhas dextrais $\mathrm{N} 30-70 \mathrm{~W}$ observadas em campo correspondem aos lineamentos NW interpretados (Figura 4.49). Esta direção foi observada principalmente nas bandas de deformação (Figura 4.48A), as quais apresentam pequenos rejeitos. A direção NW parece estar relacionada aos derrames basálticos e escarpas de falhas reconhecidos na área e que estão diretamente relacionados ao magmatismo Cretáceo. $\mathrm{Na}$ área da estrutura do Jacu, os arenitos não apresentam planos estriados.

Nas porções centrais e sudeste da área de estudo há estruturas EW com fraturas escalonadas indicando movimentos dextrais. Estas estruturas estão principalmente em terrenos permianos, mas também são encontradas em afloramentos de arenitos Pirambóia. Estas estruturas podem estar 
relacionadas a Orogenia Cabo-La Ventana (Ramos 1988; Tankard et al. 1995), que foi um evento compressional na porção sul da Bacia do Paraná, Sierras Australes na Argentina. A Orogenia CaboLa Ventana tem uma idade Permo-Triássica e afetou os sedimentos do norte da Bacia do Paraná (Cobbold et al., 1991). As estruturas N30-50E do embasamento foram também reativadas a partir da Orogenia Cabo-La Ventana na parte norte da Bacia do Paraná (Rostirolla et al. 2000).

Ocorrências de sismitos em rochas Permo-Triássicas são descritas na literatura (Riccomini, 1992, Chamani et al. 1992, Fernandes \& Coimbra, 1993). Segundo Riccomini (1995), os sismitos são evidências diretas de tectonismo sinsedimentar no Permiano Superior da Bacia do Paraná. Na área de estudo foram encontrados afloramentos com sismitos na Fm. Teresina (Figura 4.50A, B e C), as direções principais (Figura 4.50D) são NW e NE, o pequeno número de medidas (12) não permitiu a determinação de direção predominante.

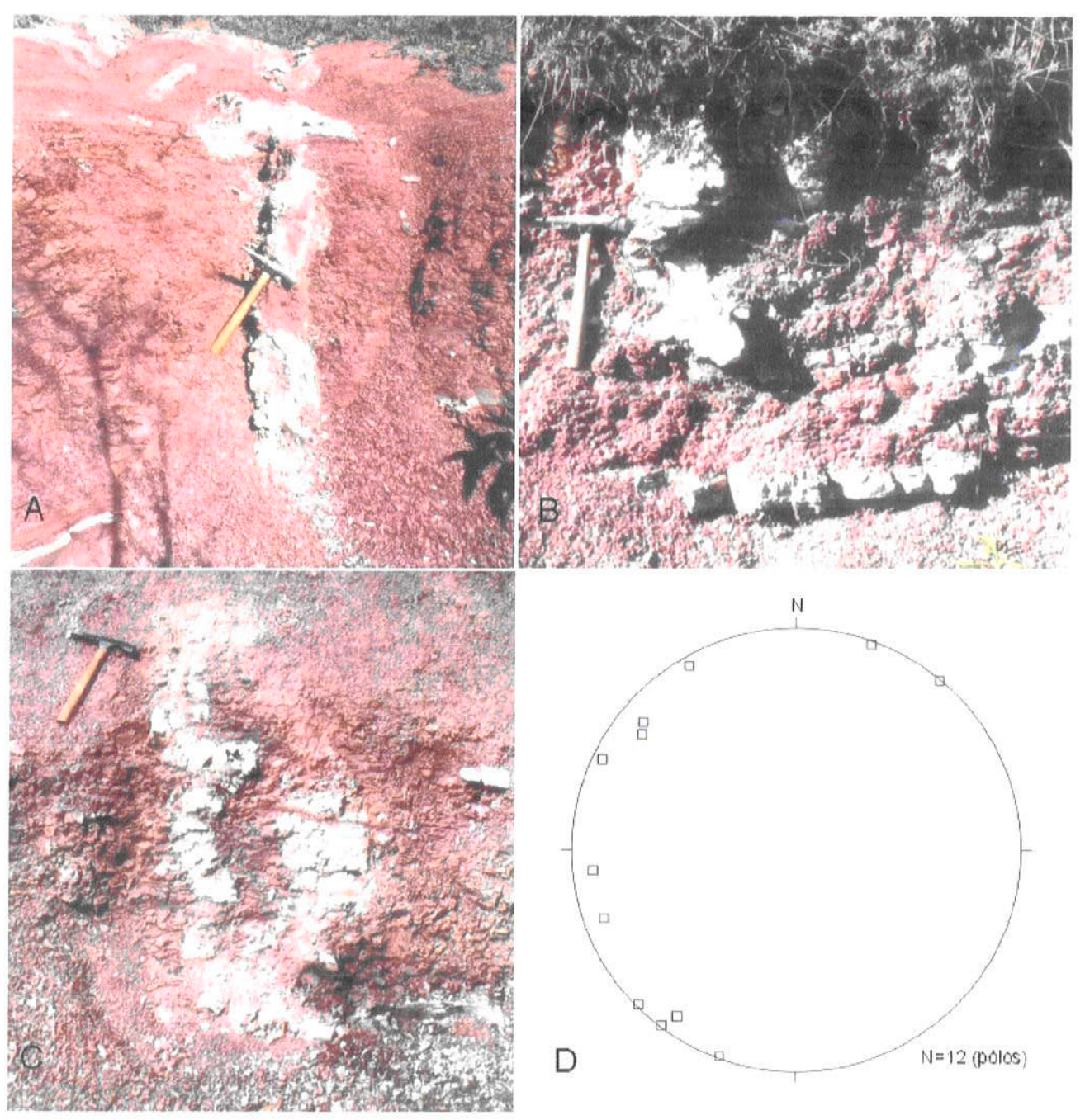

Figura 4.50: Diques clásticos e pólos das orientações. (A) Diques clásticos, $2,5 \mathrm{~km}$ SW de Porangaba (E791764, N7433165); (B) Diques clásticos, 2,0 km NE de Torre de Pedra (E789872, N7427098); (C) Diques clásticos, 5,0 km NE de Guareí, Espigão da Areia Branca (E791607, N7416907). (D) Pólos das orientações de 12 diques clásticos medidos nos pontos $\mathrm{A}, \mathrm{B}$ e $\mathrm{C}$. 
Camadas basculadas e falhas também foram encontradas na Fm. Teresina, estas estruturas têm características rúpteis e pós-deposicionais. As duas direções principais são N10-20E e N40$60 \mathrm{~W}$, embora o número de medidas seja pequeno, a direção NW parece ser predominante. As direções encontradas em afloramento correspondem às interpretadas na imagem de satélite. Foram encontradas falhas de normais (Figura 4.51, CC560 e CC597) e também falhas reversas (Figura 4.51 ,CC597a).

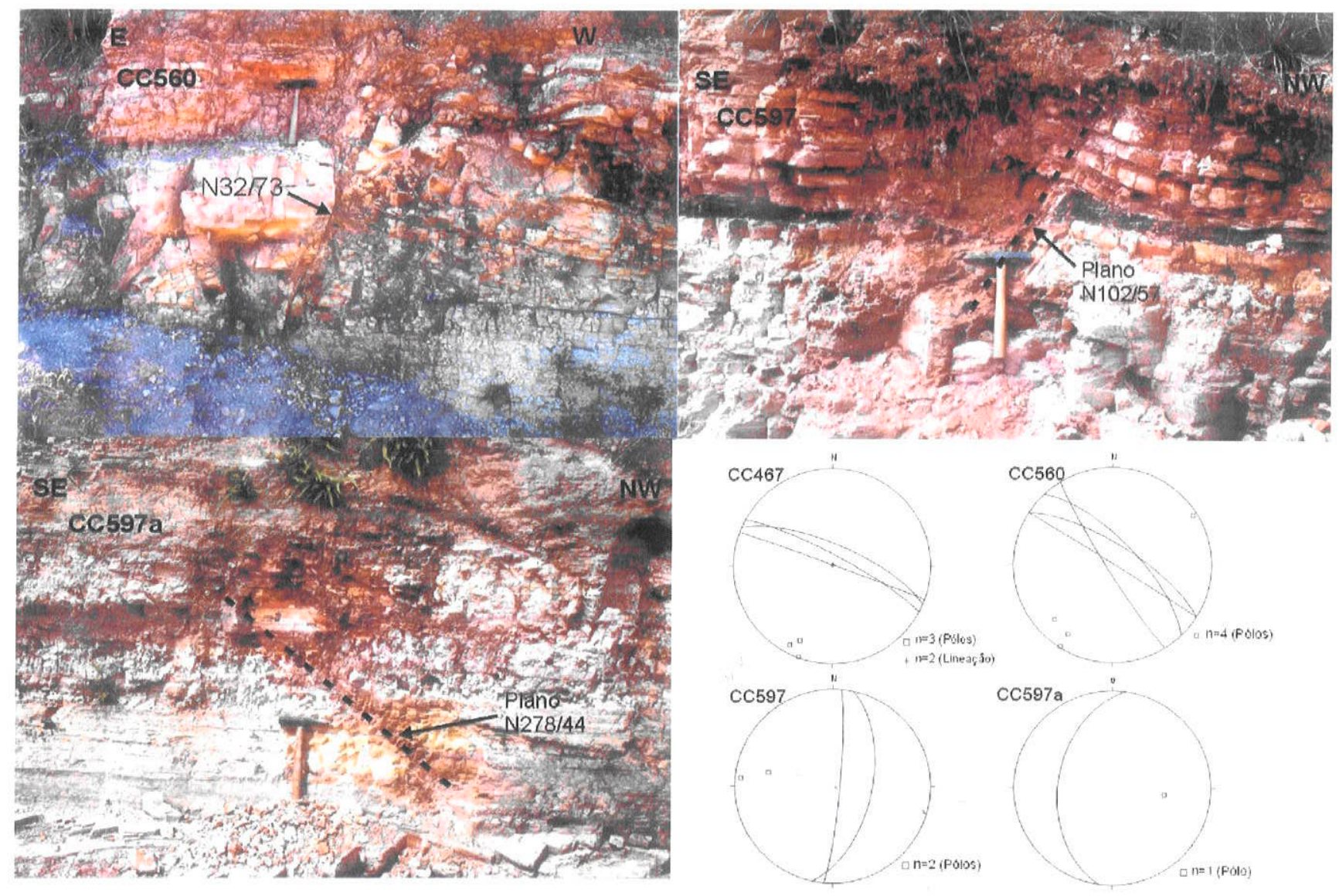

Figura 4.51:Falhas pós-deposicionais na Formação Teresina encontradas na região do Jacu. (CC560) Fazenda São Jorge (E784959, N7431189); (CC597, CC597a) Estrada Bofete-Porangaba (E789086, N7440083).

As ocorrências de arenito asfáltico estão localizadas em uma área de alta complexidade estrutural. O Alto do Sobar, Alto de Areia Branca, Alto Quebra e Alto do Morro do Bofete estão relacionados às direções de falhamento NE, NW e N. No mapa de contorno estrutural da Formação Teresina, há vários altos estruturais com formas elípticas cujos eixos maiores têm uma direção NE (Figura 4.52). O mapa de contorno estrutural foi feito com base em dados de contatos geológicos de afloramentos. 


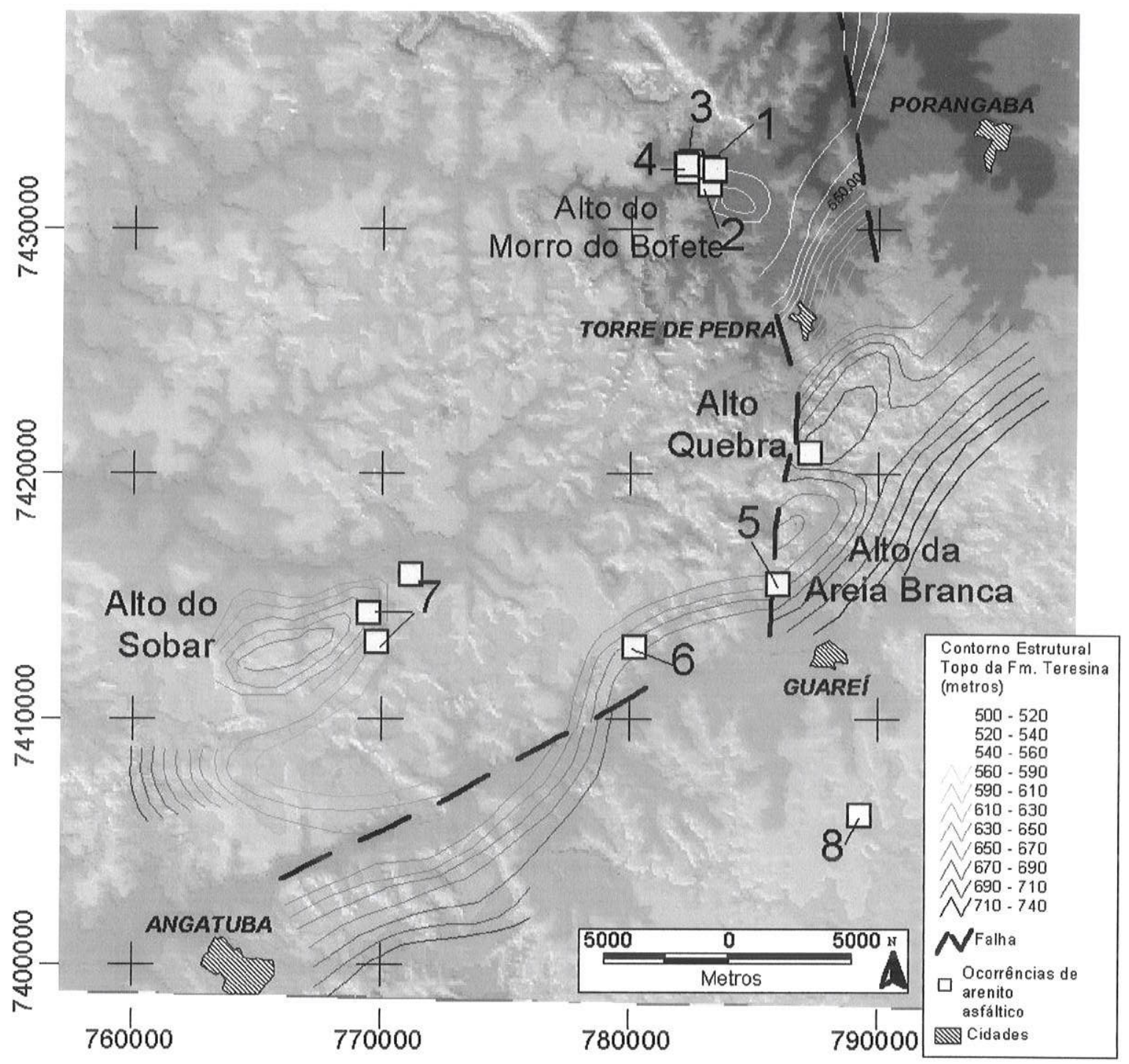

Figura 4.52: Mapa de contorno estrutural da Fm. Teresina, área da estrutura do Jacu. 1- Morro do Bofete I II e III; 2 - Faz. S. Jorge I e II; Estrada da Mina; Bairro da Mina I, II e III; 5 - Nhaíva; 6 - Itatigue; 7 - Sobar I, II e III; 8 - Jacutinga

Durante os trabalhos de campo, não foi possível encontrar afloramentos que confirmassem a relação entre as estruturas de direção NW e NE. Baseado nas imagens de sensoriamento remoto, no mapa de rede de drenagem e no MNT conclui-se que a direção NE é mais antiga que NW. Os lineamentos NW são contínuos e cruzam as estruturas NE revelando descontinuidades no traçado destas.

Uma combinação de fatores na área do Morro do Bofete incluindo a intersecção de falhas oblíquas N50W e N30E (Figura 4.53E e 4.53F), a presença de diques de rochas básicas (Figura 4.53E) e a presença de bandas de deformação em afloramentos de arenito asfáltico (Figura 4.53C) permite elaborar um modelo genético estrutural para a ocorrência de arenito asfáltico nesta região. 
Outro elemento importante na falha NW é a presença de falhas normais (Figura 4.53B), estas evidências conduzem a uma interpretação de falha transcorrente (oblíqua) e a aplicação do modelo de Riedel (Figura 4.53G). Esta falha obliqua teria pequeno rejeito direcional (não calculado) e sua interpretação foi baseada principalmente nos elemento propostos no modelo de falhamento transcorrente de Christie-Blick \& Biddle (1985). A posição dos diques de diabásio e distribuição das ocorrências de arenito asfáltico indicam uma zona dilatacional na intersecção dos falhamentos NW e $\mathrm{NE}$. Esta zona dilatacional providenciou um caminho adequado para a migração do hidrocarboneto e também para a intrusão de rocha básica. As direções dos diques básicos são praticamente as mesmas das fraturas de extensão $(T)$ associadas ao movimento oblíquo dextral NW na área de ocorrência do Morro do Bofete (Figura 4.53g). Gartrell et al. (2003) desenvolveram um modelo tridimensional o qual indica a geração de zonas dilatacionais ao redor das intersecções de falhas. Estas zonas dilatacionais são importantes caminhos para a migração de hidrocarbonetos e podem ser consideradas como elementos importantes na ocorrência de hidrocarbonetos da área de estudo. 

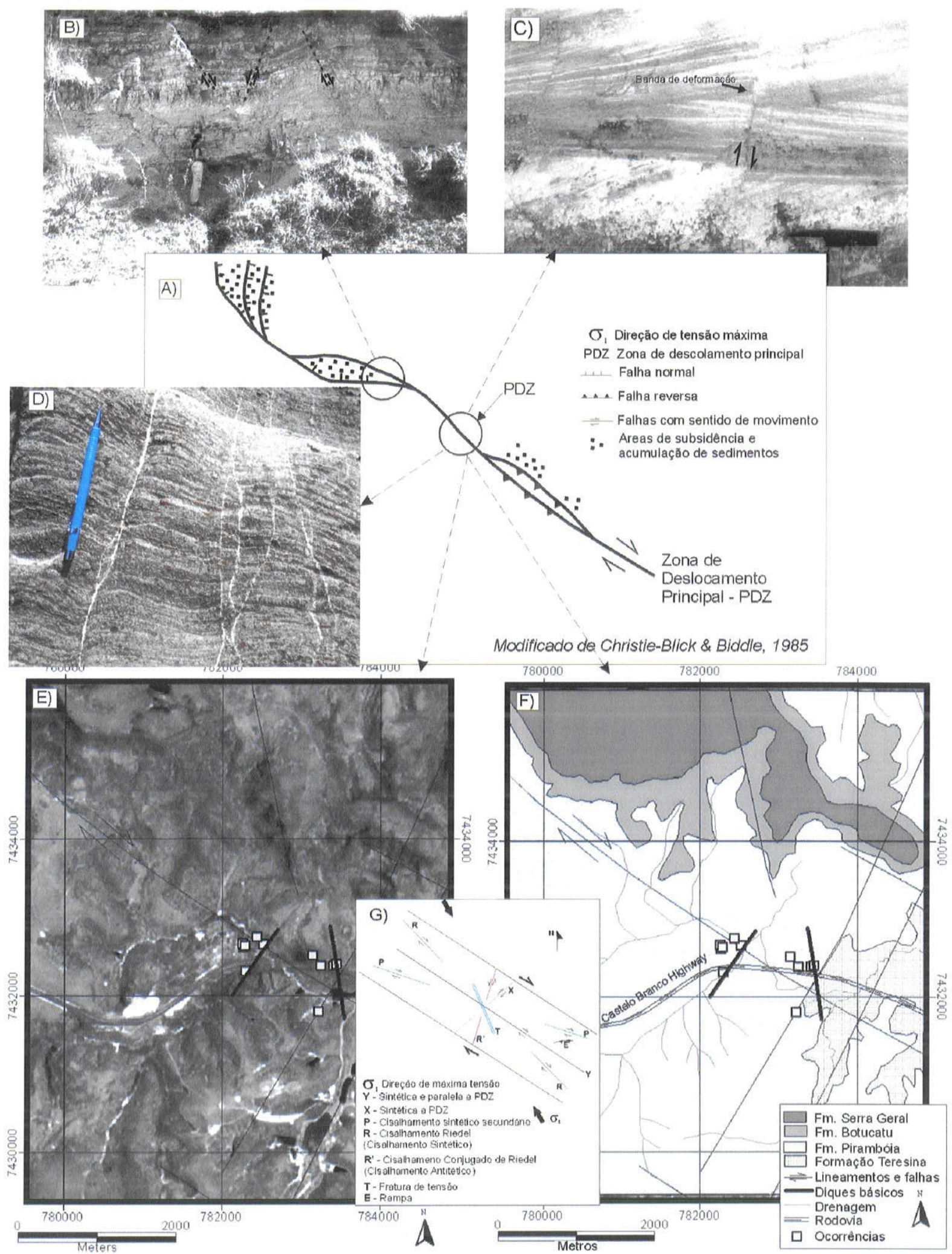

Figura 4.53: Diagrama com as diferentes evidências estruturais e componentes relacionados às hipóteses de gênese do arenito asfáltico na área do Domo do Jacu. (A) Diagrama de falha oblíqua dextral na área da ocorrência do Morro do Bofete. (B) Falhas normais relacionadas à região de alívio. (C) Banda de deformação no reservatório Pirambóia. (D) Banda de Deformação na ocorrência de arenito asfáltico. (E) Imagem ETM+ Landsat Pancromática com indicação da falha oblíqua dextral e dos lineamentos NE, diques de rocha básica e ocorrência estão assinalados. (F) Esboço geológico da porção leste da estrutura do Jacu com várias ocorrências, diques de rochas básicas, falhas e lineamentos. (G) Modelo de Riedel comparado aos elementos presentes na imagem de satélite e mapa geológico. 
A zona de falha NW é significativa para a migração de hidrocarbonetos, porque a direção NW influencia a geração de espaços e barreiras para a migração de fluidos. Além disso, a direção NW reativou estruturas NE. As barreiras para migração de fluido estão relacionadas a presença de bandas de deformação com uma grande redução de porosidade dentro das bandas. No afloramento de arenito asfáltico (Figura 4.53D), há bandas de deformação sem preenchimento de hidrocarbonetos o que indica uma geração prévia das falhas NW em relação a acumulação de hidrocarbonetos nos arenitos Pirambóia. Aydin (1978) observou a redução de porosidade associada à banda de deformação. Os espaços para migração de fluidos estão relacionados às fraturas de extensão e às intersecções de zonas de falha NW-NE.

É marcante a importância da direção NW para o processo de migração e sua relação com falhas NE mais antigas. Há vários diques de rochas básicas intrudindo as falhas NE, o que indica a reativação destas estruturas no início do magmatismo Serra Geral.

As falhas NE intrudidas por diques de rochas básicas indicam um evento tectônico ativo desde o final do Jurássico pelo menos. Bandas de deformação de direção NE encontradas no topo da Formação Botucatu indicam uma atividade Juro-Cretácea destas falhas, o que demonstra a importância da direção NE ao longo do tempo.

As evidências de movimentação tectônica (indicadores cinemáticos) encontradas na área do Jacu não são conclusivas do ponto de vista de indicação do tipo principal de movimentação se por gravidade ou por transcorrência. Assim, procurou-se apresentar uma interpretação compatível com os elementos disponiveis e com a presença de hidrocarbonetos e diques de rocha básica. Soares (1974) descarta a possibilidade de movimentação transcorrente na área de estudo estar relacionada aos altos estruturais. Entretanto, Riccomini (1995) a partir da caracterização de movimentações transcorrentes dextrais e sinistrais no alto estrutural de Pitanga relaciona as estruturas da área do Jacu (Alto de Carlos Prenz e Domo do Jacu) com eixos de dobramento associados à transcorrência dextral ao longo do Alinhamento do Rio Paranapanema.

Embora as direções de esforços não tenham sido definidas, caracteriza-se a importância das falhas em relação à gênese dos arenitos asfálticos e a origem principal destes elementos na Reativação Pós-Paleozóica.

\subsection{2 Área do Alto de Anhembi}

A área do alto estrutural de Anhembi é caracterizada pela presença de estruturas rúpteis pósdeposicionais. Entre elas, destacam-se as fraturas presentes nos siltitos Teresina e as bandas de deformação nos arenitos Pirambóia. Interpreta-se que estas estruturas foram geradas por eventos mesozóicos, embora a reativação de estruturas permianas também seja considerada. Os ângulos de mergulho das fraturas e bandas de deformação em geral são da ordem de $80^{\circ}$ ou maiores. Estas 
estruturas, assim como na área do Jacu, têm um arranjo NE e NW. Tais fraturas são interpretadas como secundárias relacionadas aos diferentes eventos rúpteis superimpostos. Em poucos afloramentos foi possível observar os planos de falha com a direção de fraturamento principal. Em apenas alguns afloramentos, foi possível medir planos estriados que representam indicações diretas da direção de movimentação tectônica. O arranjo angular das fraturas em afloramento auxiliou na definição do sentindo de movimentação. Desse modo, estes arranjos foram interpretados como fraturas escalonadas. Em campo, ao longo das falhas, os principais indicadores cinemáticos encontrados foram as fraturas escalonadas (Figura 4.54A) e feições anastomosadas características de bandas de deformação (Figura 4.54C).

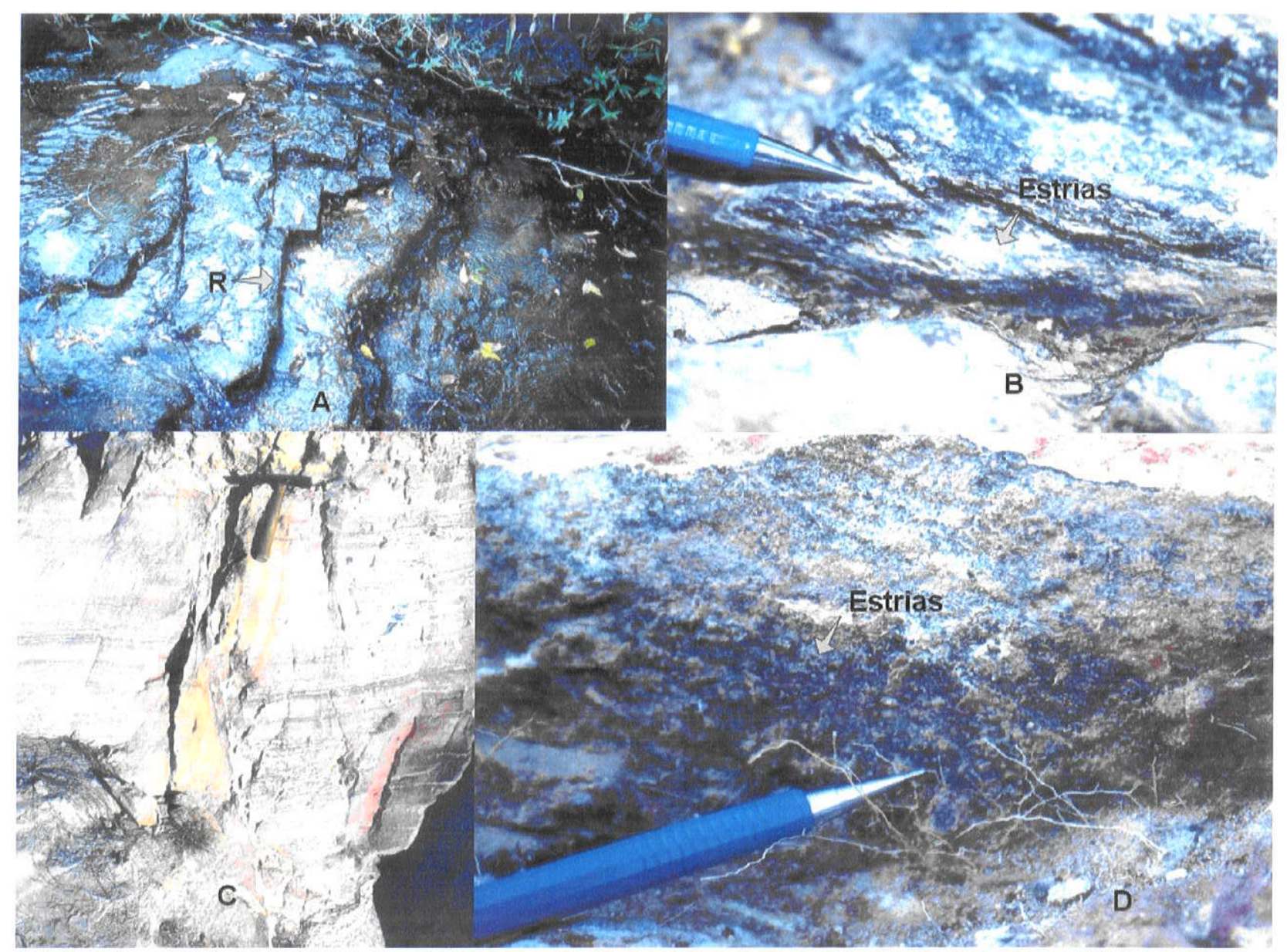

Figura 4.54: Principais indicadores cinemáticos encontrados na região de Anhembi. (A) Fraturas escalonadas em siltitos da Fm. Teresina, ponto CC279; (B) Estrias em siltitos da Fm. Teresina, ponto CC585 ; (C) Banda de deformação em arenito da Fm. Pirambóia, ponto CC444; (D) Estrias em arenito com "filme" de óxidos de ferro, ponto CC444.

As bandas de deformação ocorrem nos arenitos da Formação Pirambóia e apresentam planos de rejeitos milimétricos a centimétricos, em alguns locais o rejeito chega a ser decimétrico. As bandas de deformação ocorrem em conjuntos ou zonas de bandas, onde a somatória dos pequenos rejeitos é 
da ordem de metros. Também observou-se nas bandas de deformação "filmes" de óxidos ferro recobrindo os planos de rejeito. Nestes casos, foram observadas estrias realçadas pelo óxido de ferro Figura 4.54B e D). Microscopicamente as bandas de deformação são caracterizadas pela diminuição da porosidade com diminuição do tamanho dos grãos (cominuição) e preenchimento dos poros por um cimento silicoso. Nos siltitos da Fm. Teresina, as rochas cataclásticas são caracterizadas por arranjos geométricos definidos e organizados em famílias de fraturas de Riedel ou fraturas escalonadas.

Os lineamentos interpretados a partir de imagens de sensoriamento remoto, modelo numérico de terreno e rede de drenagem indicam direções principais N45-70W e N10-30E como as principais. Alguns lineamentos E-W foram interpretados (Figura 4.55A e B).
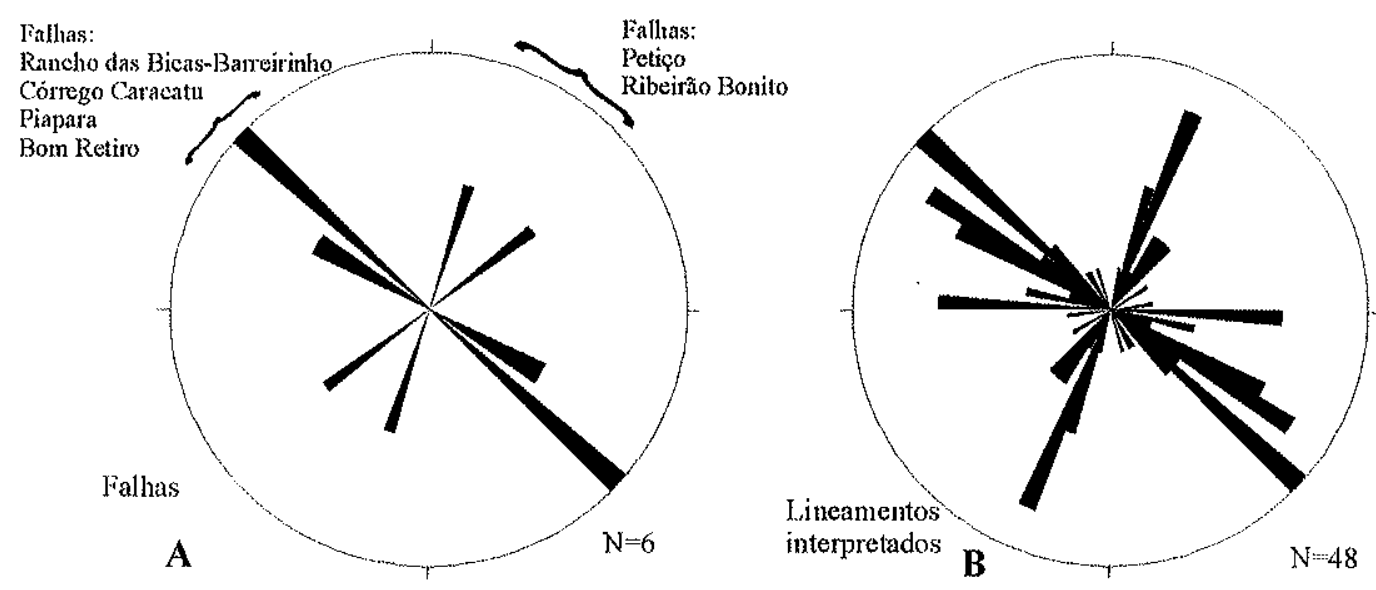

Figura 4.55: Rosetas de falhas e lineamentos. (A) Roseta das falhas NE sinistrais e falhas NW sinistrais; (B) roseta dos lineamentos interpretados em imagens de satélite, MNT e rede de drenagem.

Em campo foram confirmadas falhas obliquas sinistrais N50-60W. Estas falhas provavelmente têm características transtensionais, inclusive com algumas intrusões ígneas básicas ao longo da direção principal. Entre estas, destaca-se a intrusão de um dique de comprimento quilométrico ao longo da Falha Rancho das Bicas-Barreirinho (Figura 4.59, a escala não permite a representação do dique ao longo da falha nesta figura) com bloco baixo para nordeste. As falhas NE sinistrais também foram confirmadas em duas falhas principais com direções N20E a N50E. As falhas NE são menos freqüentes e os indicadores cinemáticos raros. Além disso, os lineamentos interpretados NE caracterizam-se por serem menores que os NW e por serem segmentados por estes. Assim, houve dois eventos principais, um mais antigo NE e um mais jovem NW. As estrias encontradas em poucos afloramentos (Figura 4.54B e D) indicam movimentação obliqua com componente gravitacional nas falhas do Alto de Anhembi. Nos estereogramas dos cinco afloramentos (Figura 4.56) com evidências 
de lineações podem ser observados o alto ângulo dos planos de fraturamento e as respectivas lineações.

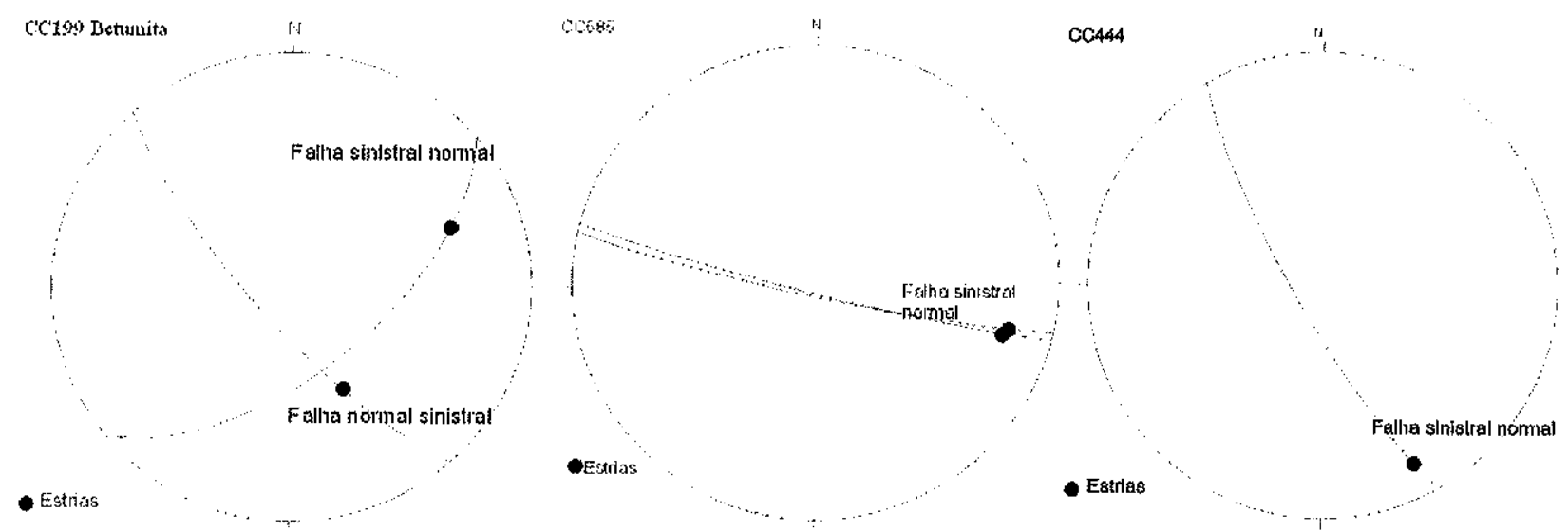

Figura 4.56: Estereogramas das lineações e planos correspondentes encontrados na região de Anhembi.

Estas estruturas segmentam o Alto Estrutural de Anhembi e provocam o basculamento dos blocos para sudoeste no bloco sul e para nordeste no bloco norte (Figuras 4.57 e 4.59). O eixo principal da estrutura tem direção NW. As ocorrências de arenito asfálticos localizam-se junto dos principais lineamentos interpretados, à exceção da ocorrência do Braço da Represa localizada a cerca de $1 \mathrm{~km}$ do lineamento mais próximo. 


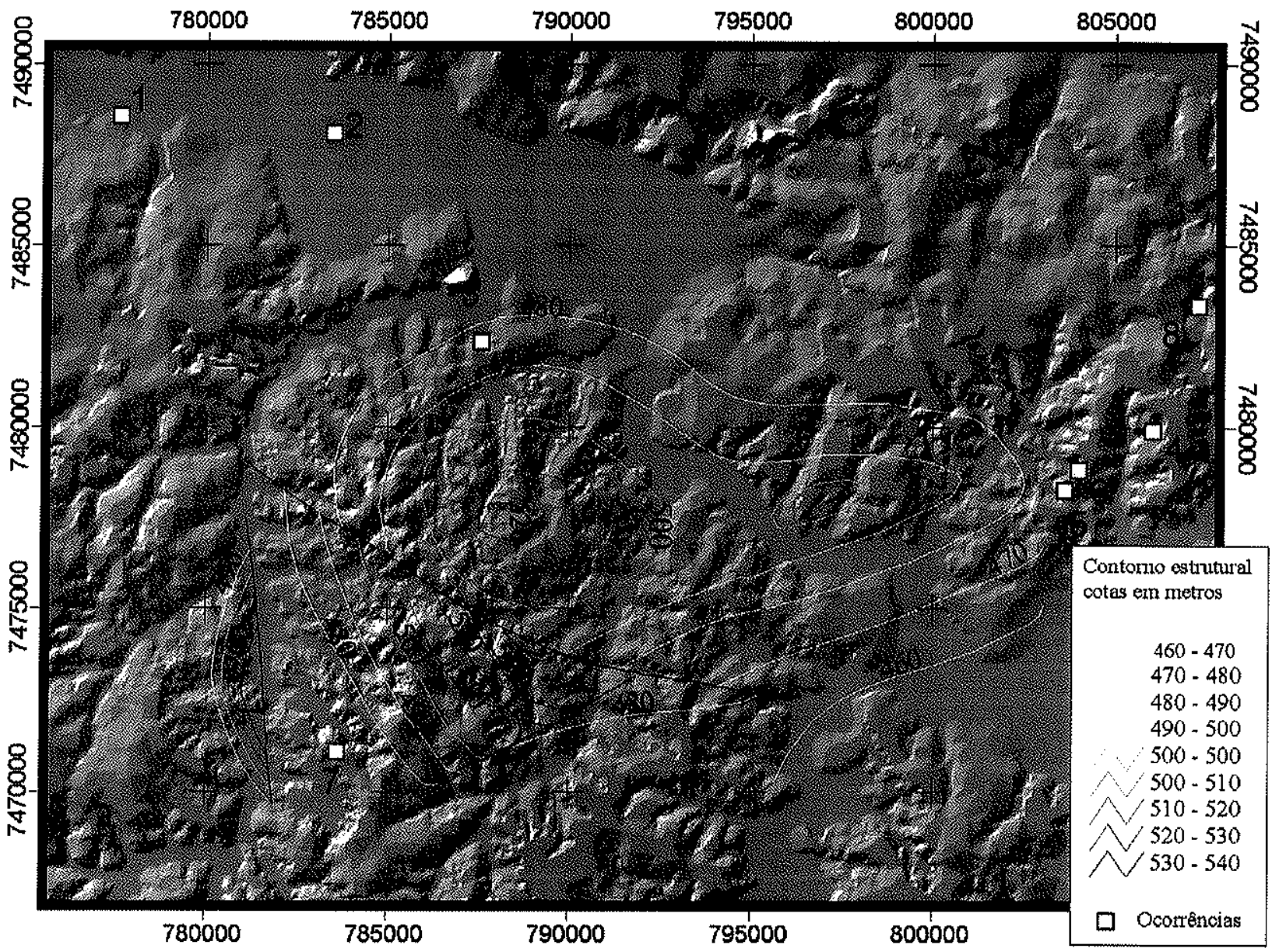

Figura 4.57: Mapa de contorno estrutural da Formação Teresina na região do Alto de Anhembi. Ocorrências: 1 Porto Martins; 2 - Volta Grande; 3 - Braço da Represa; 4 - Betumita; 5 - Moquém I; 6 - Moquém II; 7 - Piapara; 8 - Faz. Ribeirão Claro.

Em campo, na ocorrência do Braço da Represa e principalmente na ocorrência Betumita foram encontradas evidências de movimentação tectônica nas direções NE e NW. Nestes casos, foram encontradas bandas e zonas de bandas de deformação (Figuras 4.58A e B). É importante salientar que em escala mesoscópica estas bandas são caracterizadas por apresentarem planos de cominuição livres de hidrocarbonetos. Além disso, microscopicamente não foram notadas quaisquer feições indicativas de expulsão dos hidrocarbonetos dos planos de cominuição, durante o processo de falhamento. As bandas de deformação encontradas correspondem a falhas $N W$ e $N E$, logo interpreta-se que a migração dos hidrocarbonetos ocorreu após a geração destes falhamentos. 


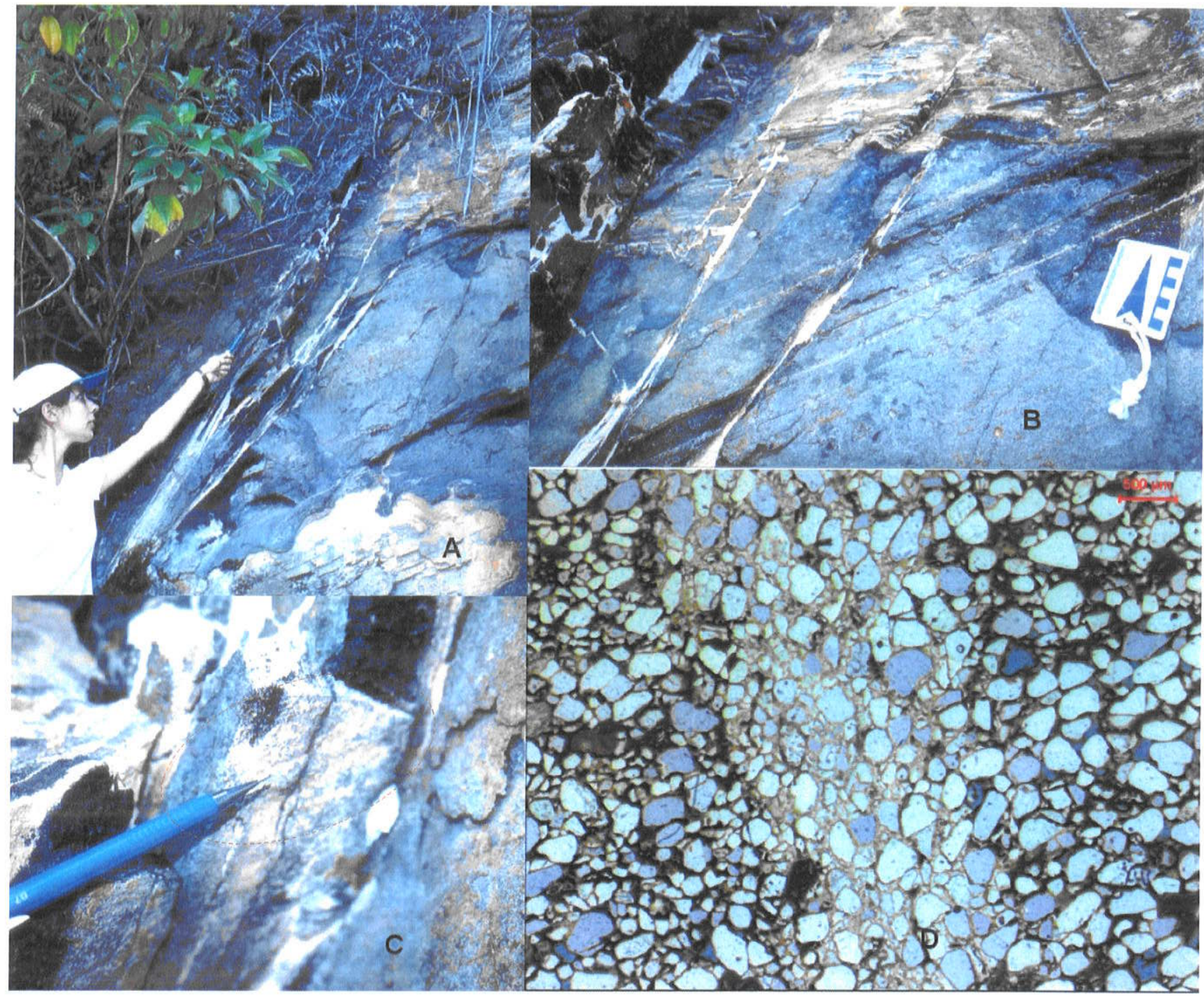

Figura 4.58: Bandas de deformação encontradas na ocorrência Betumita (CC199). (A)Zona de Banda de deformação com rejeito aparente de $10 \mathrm{~cm}$; (B) Detalhe do rejeito; (C); Estrias no plano de falhamento; (D) Fotografia em lupa com aumento de $6 x$, cimentação silicosa de grãos na banda de deformação com ausência de hidrocarbonetos. 


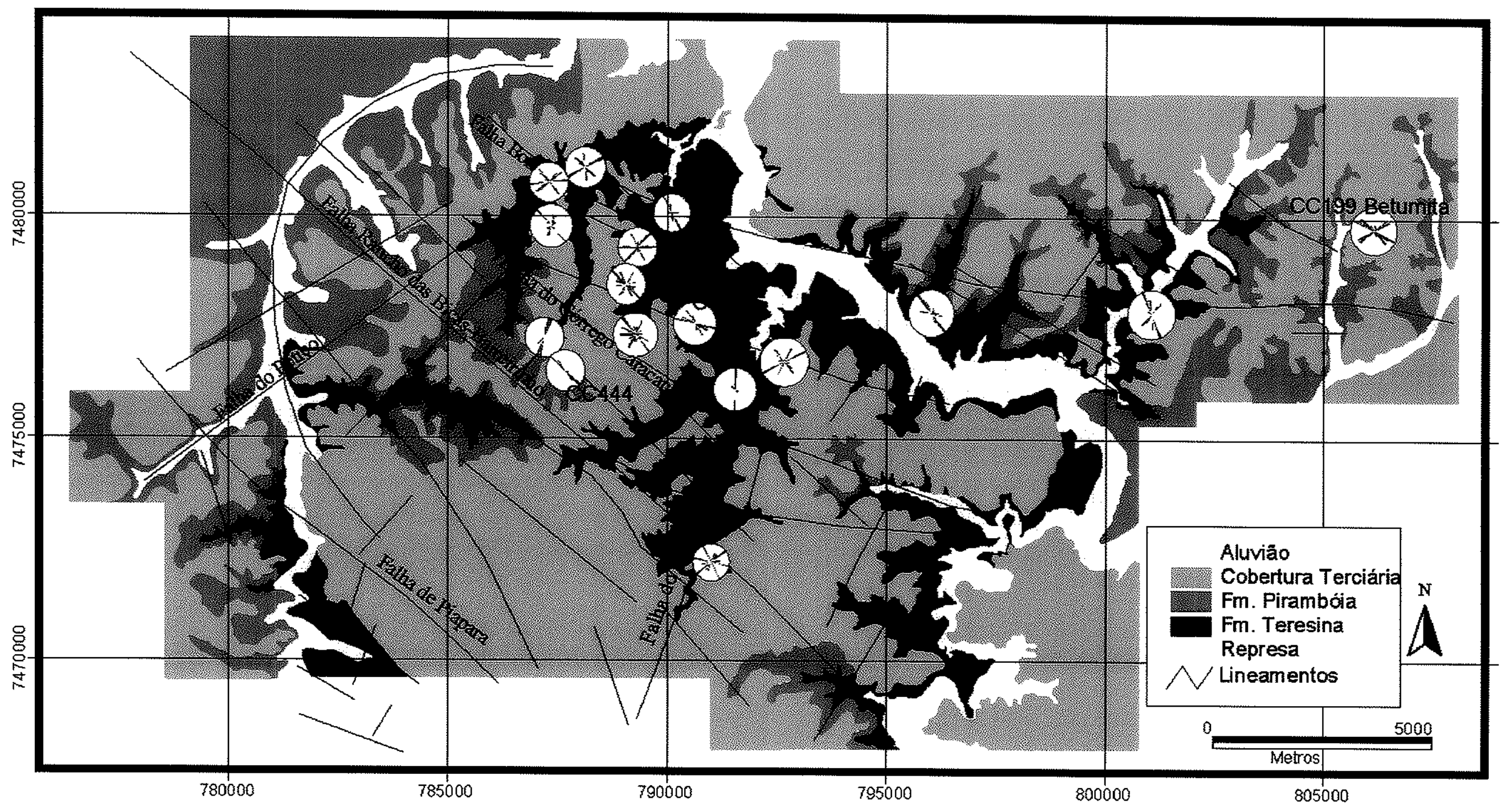

Figura 4.59: Esboço geológico com lineamentos intepretados e rosetas de sistemas de fraturamento na área do alto estrutural de Anhembi. 


\subsection{Geocronologia}

As datações de rochas básicas foram feitas a partir dos métodos $\mathrm{K} / \mathrm{Ar}$ e $\mathrm{Ar}^{40} / \mathrm{Ar}^{39}$. Foram utilizadas amostras de seis localidades diferentes (Figura 4.60).

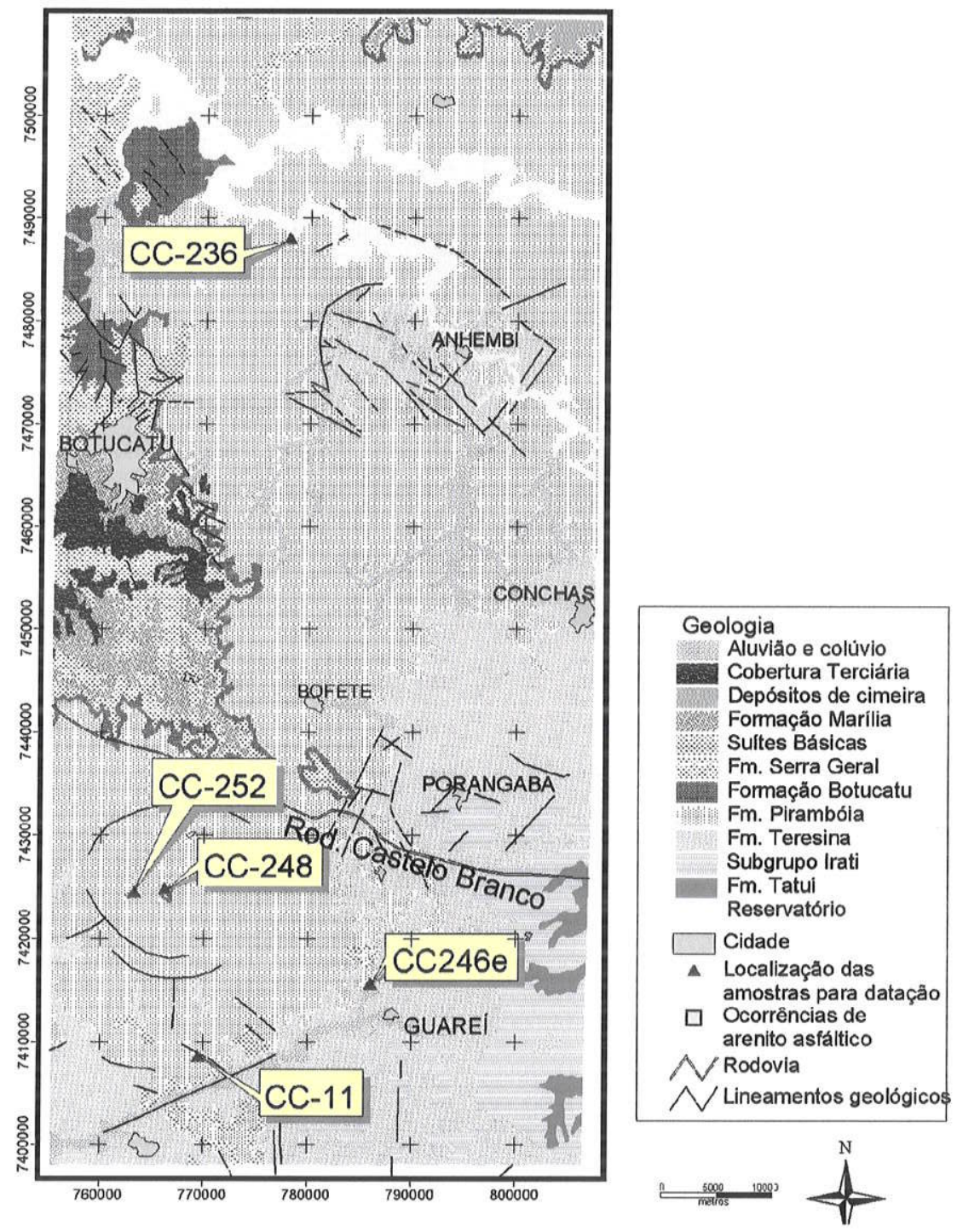

Figura 4.60: Localização das amostras de rochas básicas utilizadas para datação $\mathrm{K} / \mathrm{Ar}^{\mathrm{e}} \mathrm{Ar}^{40} / \mathrm{Ar}^{39}$.

Em lâmina delgada, observaram-se, para todas as amostras, alterações dos minerais com evidências de sauciritização e sericitização. Os feldspatos são os minerais que apresentam maior fragilidade em relação aos processo de alteração (Figura 4.61). Entretanto, macroscopicamente, as amostras coletadas são de rocha sã, não são encontradas fissuras ou mesmo óxidos na superfície ou em corte das amostras. Dessa forma, interpreta-se que a alteração dos minerais encontrada nas 
amostras analisadas esteja relacionada a processos deutéricos. Assim, procurou-se adequar o método de datação em função das características das amostras, com especial atenção ao grau de alteração das amostras (Tabela 11). Idealmente procura-se datar as amostras pelo método $\operatorname{Ar}^{40} / \mathrm{Ar}^{39}$ em feldspatos que forneceria os resultados mais precisos, em seguida procura-se utilizar a análise $\mathrm{Ar}^{40} / \mathrm{Ar}^{39}$ em rocha total e finalmente foram feitas datações $\mathrm{K} / \mathrm{Ar}$ em todas as amostras para se determinar a faixa de idades esperada; entretanto, o método KJAr fornece precisão sensivelmente menor.

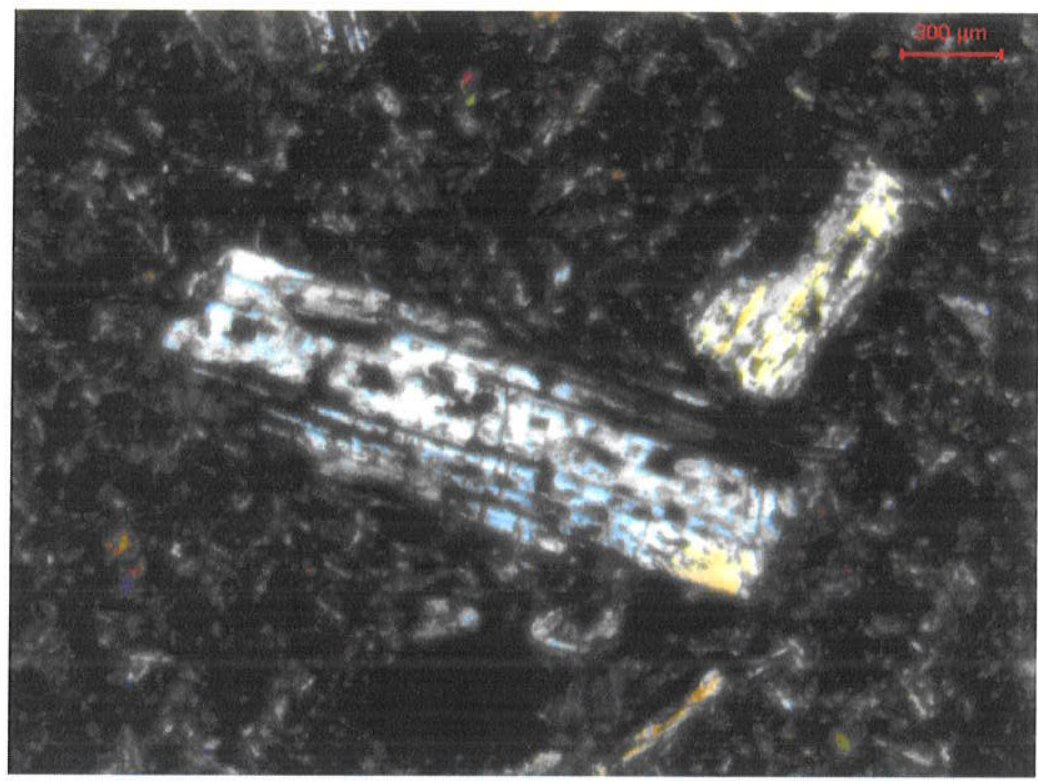

Figura 4.61: Exemplo de felspato alterado em diabásio da amostra CC252.

Tabela 11: Datações em amostras de basaltos e diabásios da área de estudo.

\begin{tabular}{|c|c|c|}
\hline Amostra & Métodos & Resultados \\
\hline CC11y & $\mathrm{Ar}^{40} / \mathrm{Ar}^{39} \mathrm{RT} \ldots \ldots \ldots \ldots \ldots \ldots$ & $134 \pm 2 \mathrm{Ma}$ \\
\hline $\mathrm{CC} 236$ & $\mathrm{Ar}^{40} / \mathrm{Ar}^{39} \mathrm{RT} \ldots \ldots \ldots$ & $134 \pm 2 \mathrm{Ma}$ \\
\hline CC246e & $\mathrm{Ar}^{40} / \mathrm{Ar}^{39} \mathrm{~F} \ldots \ldots \ldots \ldots \ldots \ldots \ldots \ldots$ & $127 \pm 4 \mathrm{Ma}$ \\
\hline CC248 & K/Ar RT............................... & $129 \pm 3 \mathrm{Ma}$ \\
\hline CC252 & K/Ar RT .................................. & $131 \pm 4 \mathrm{Ma}$ \\
\hline
\end{tabular}

$\mathrm{F}=$ feldspato; $\mathrm{RT}=$ rocha total

As idades fornecidas pela datação em rocha total $\mathrm{Ar}^{40} / \mathrm{Ar}^{39}$ forneceu os resultados mais precisos e confiáveis.

As amostras CC11y e CC236 analisadas pelo método $\mathrm{Ar}^{40} / \mathrm{Ar}^{39}$ em rocha total forneceram os resultados mais significativos para a área de estudo especialmente devido à precisão das análises. 
A amostra CC11y Rocha Total apresentam valores de liberação de gás adequados e coerentes para os três grãos analisados (Figura 4.62). De um modo geral, os três grãos apresentam uma liberação mais baixa no início do aquecimento marcada pelo step A (Figura 4.62A, B e C). Os platôs são estabelecidos nos últimos step, geralmente D,E,F. Este comportamento pode ser explicado a partir da perda de argônio nas porções externas dos grãos. $O$ gráfico 4.63 apresenta as idades referentes somente a estes steps de maior estabilidade considerados como platôs. $O$ termo pseudom platô, é utilizado nos gráficos devido às pequenas variações que estritamente não permitem classificá-los como platôs.

\section{7 / CC-11y / Rocha Total}
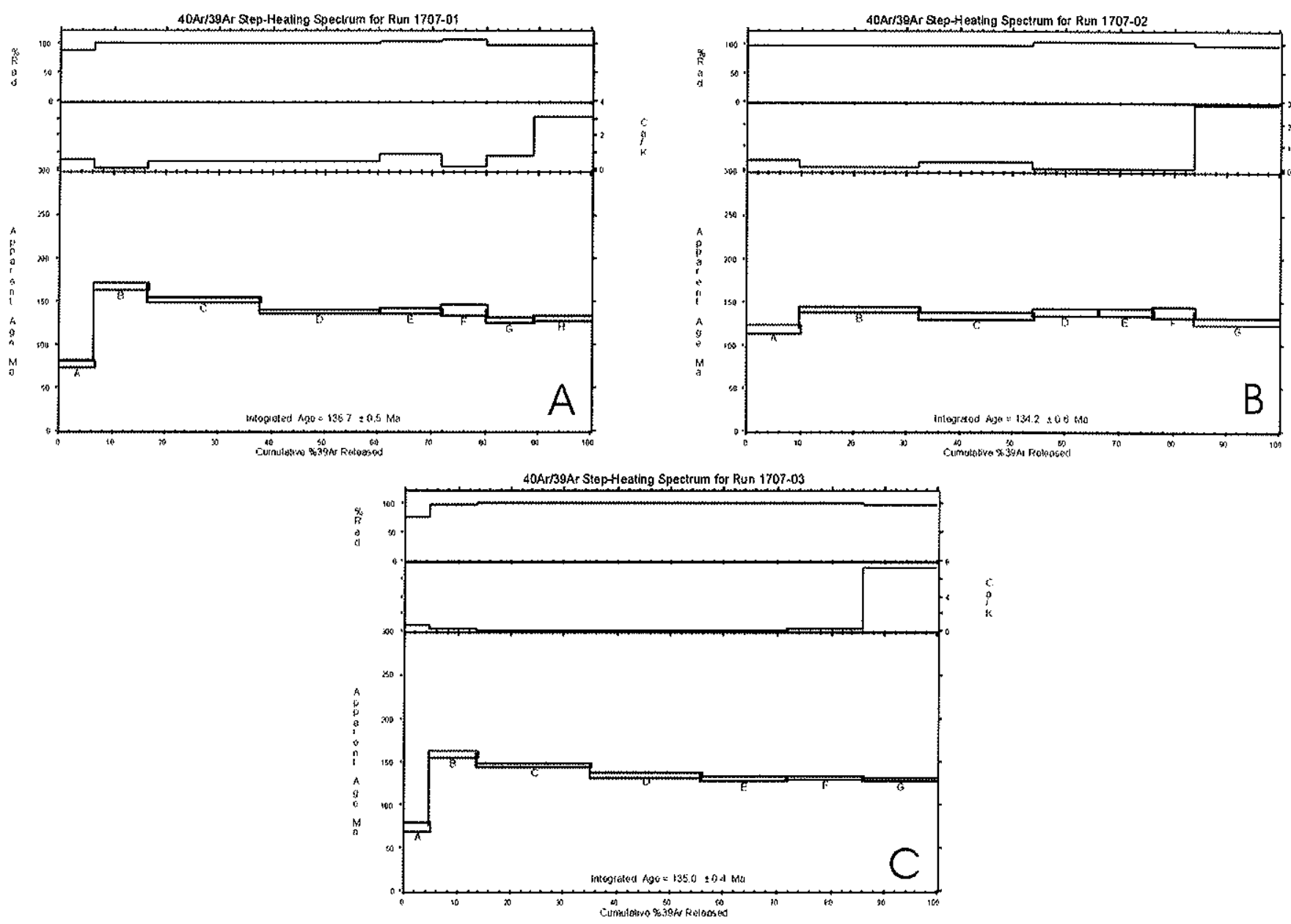

Figura 4.62: Espectro de liberação de gás para os 3 grãos de rocha total da amostra CC11y.

(A) grão 1; (B) grão 2; (C) grão 3.0 s três gráficos mostram valores coerentes nas proporções de ${ }^{39} \mathrm{Ar} \mathrm{liberadas.}$ 


\section{7 / CC-11y / Rocha Total}

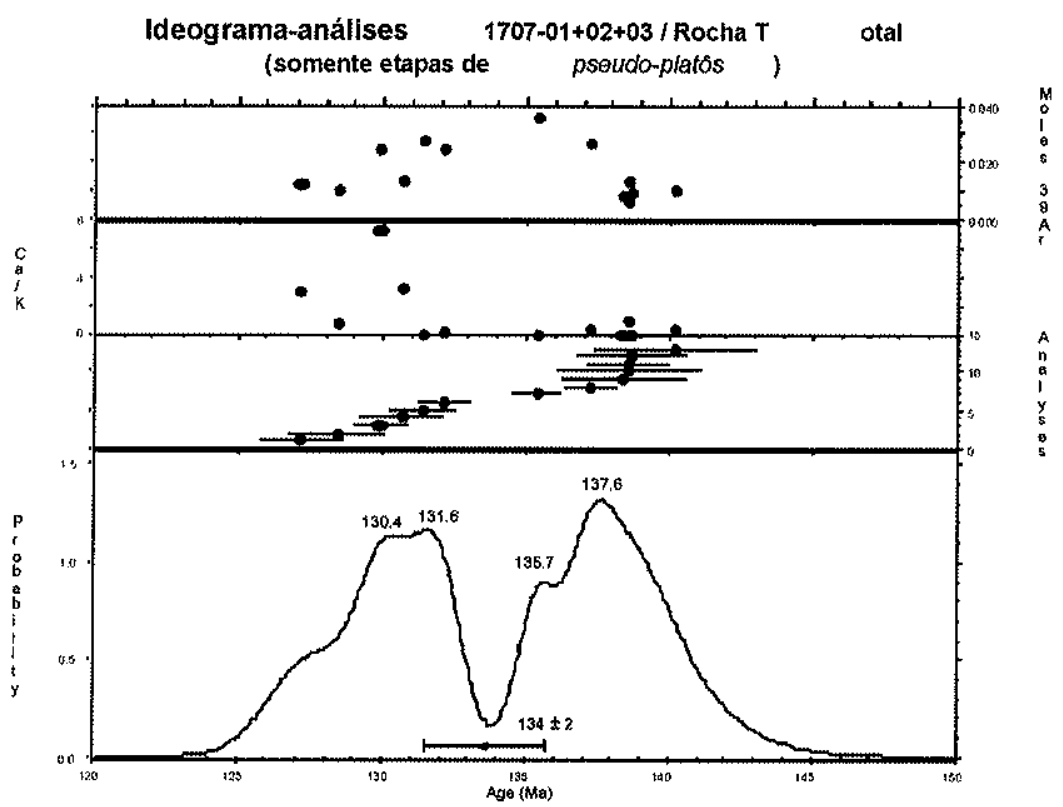

Figura 4.63: Ideograma da amostra $\mathrm{CC} 11$ y com frequêencia de análises, razão $\mathrm{Ca} / \mathrm{K}$ e quantidade de gás disponível (Moles de ${ }^{39} \mathrm{Ar}$ ).

Os grãos da amostra CC236 Rocha Total apresentam altos valores de liberação de gás inicial, especialmente nos steps A, B,C (Figura 4.64). Desse modo, considerou-se o platô referente preferencialmente aos steps $D, E, F$, com variações entre os grãos. O ideograma da Figura 4.65 mostra a idade integrada para os steps considerados como platôs. 
1709 / CC-236 / Rocha Total
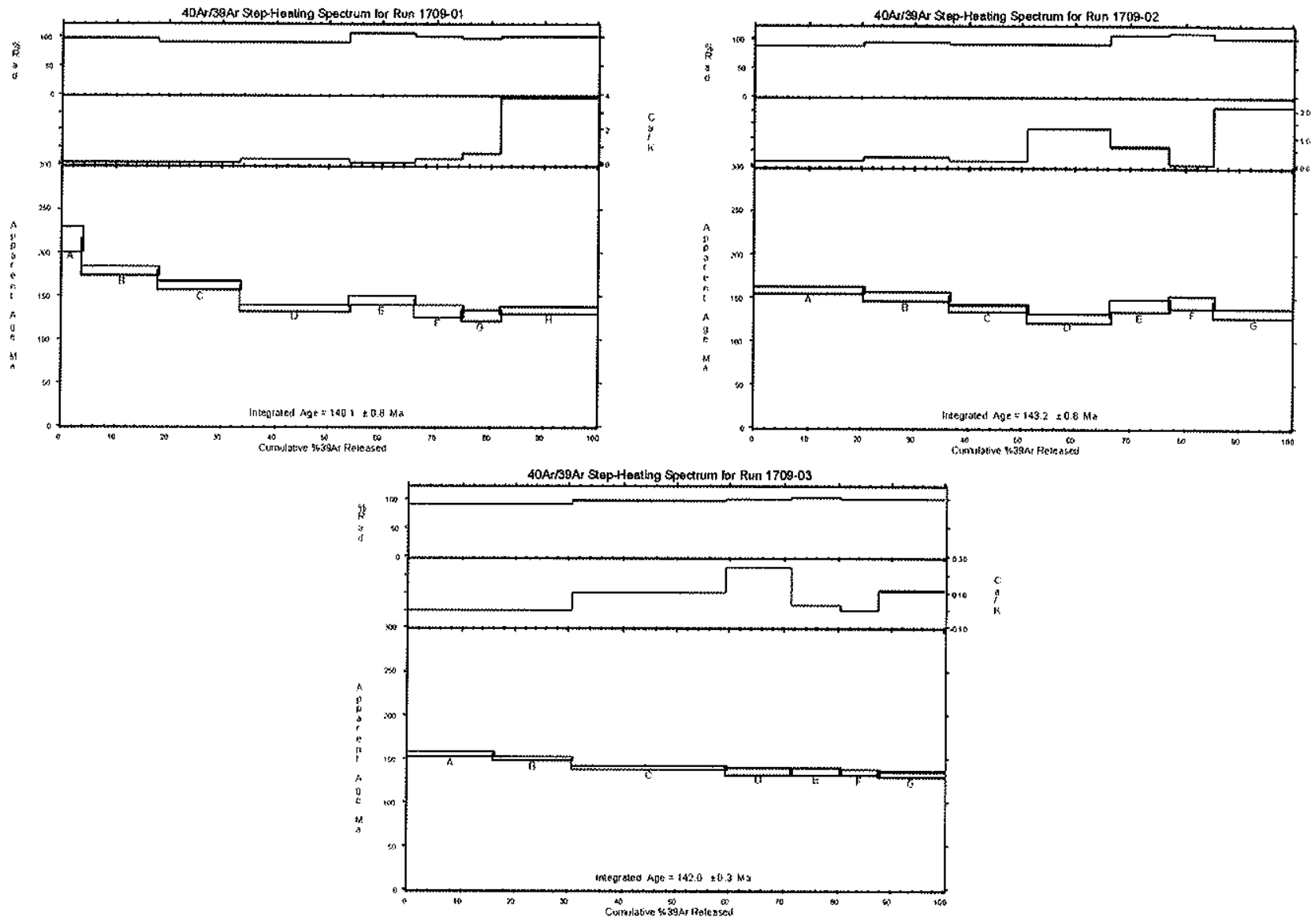

Figura 4.64: Espectro de liberação de gás para os 3 grãos de rocha total da amostra Cc236.

(A)grão 1; (B)grão 2; (C)grão 3 . Os três gráficos mostram valores inicias altos de liberação de gás, steps A, B,C.

A análise de feldspatos da amostra CC246e mostra que os steps iniciais têm valores anômalos com estabilização dos steps finais. Este comportamento pode estar relacionado à alteração precoce dos grãos logo após o término da cristalização. O comportamento de pseudo-platô dos últimos steps (Figura 4.66) pode ser interpretado como reflexo da preservação das porções internas do grão. Entretanto considera-se que a idade integrada obtida ( $127 \pm 4 \mathrm{Ma})$ pode não refletir a idade de cristalização pois pode ter havido perda de argônio. 


\section{9 / CC-236 / Rocha Total}

Ideograma-análises

1709-01+02+03 / Rocha Total

(somente etapas de

pseudo-platôs )

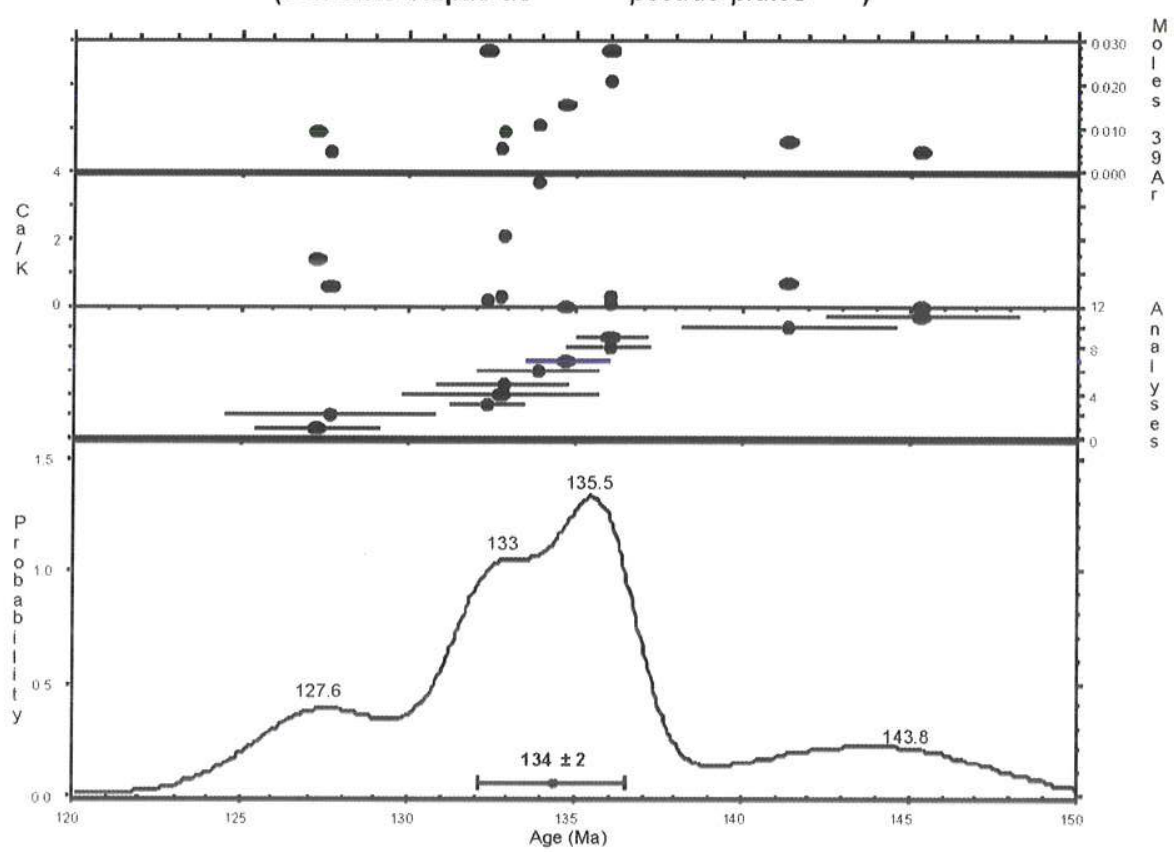

Figura 4.65: Ideograma da amostra CC236 com freqüência de análises, razão Ca/K e quantidade de gás disponível (Moles de ${ }^{39} \mathrm{Ar}$ ).

\section{3 / CC-246E / Feldspato}
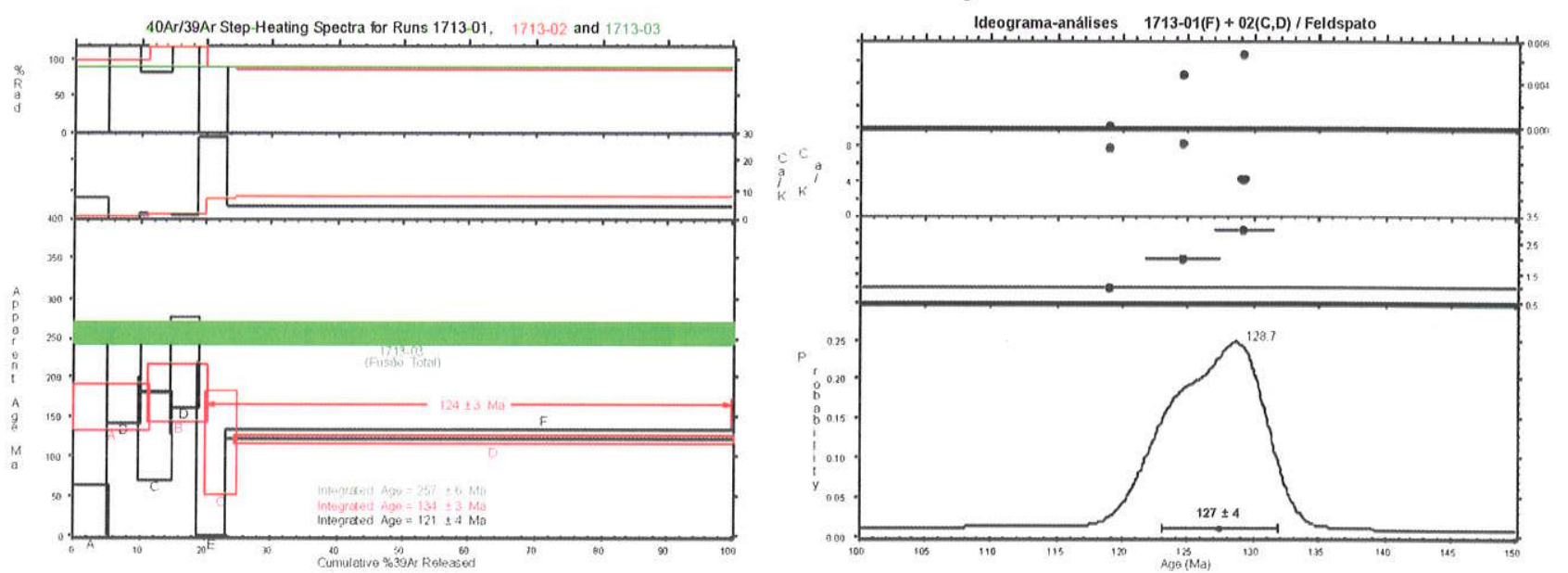

Figura 4.66: Ideograma e espectro de liberação de gás da amostra CC246e com freqüência de análises, razão $\mathrm{Ca} / \mathrm{K}$ e quantidade de gás disponível (Moles de ${ }^{39} \mathrm{Ar}$ ).

Os resultados demonstram que para a análise $\mathrm{Ar}^{40} / \mathrm{Ar}^{39}$ em feldspatos tanto a fusão total quanto o aquecimento gradual (step heating) não forneceram resultados adequados. De modo geral, observou-se que houve um enriquecimento anômalo em $\mathrm{Ar}^{39}$. Este enriquecimento pode ter sido 
causado justamente pelas soluções do final do processo de cristalização que difundiram o Ar ou mesmo estar relacionado a soluções provenientes dos sucessivos pulsos magmáticos que a área sofreu durante a Reativação Pós-Paleozóica.

Nas análises pelo método ${ }^{40} \mathrm{Ar} /{ }^{39} \mathrm{Ar}$ para os feldspatos das amostras $\mathrm{CC} 11 \mathrm{y}, \mathrm{CC} 236, \mathrm{CC} 248 \mathrm{e}$ CC252 não foram definidas idades. Para a amostra CC11y houve uma liberação inicial anômala de gás, provavelmente relacionada a alta concentração de Ar na borda do grão. Esta alta concentração pode ser originada de fluidos remanescentes do final da cristalização e enriquecidos neste elemento. Este mesmo comportamento é observado nas amostras CC236 e CC252. Já na amostra CC248 há pouco gás disponível o que impossibilita determinação.

As amostras CC11y e CC236, cujas datações são de $134 \pm 2 \mathrm{Ma}{ }^{40} \mathrm{Ar} /{ }^{39} \mathrm{Ar}$ foram coletadas em um afloramento da soleira de Angatuba ( $\mathrm{CC} 11 \mathrm{y})$ e em um dique de diabásio junto à ocorrência de arenitos asfáltico de Porto Martins (CC236). Estas idades correspondem às primeiras manifestações magmáticas da Reativação Paleozóica e são significativas para a melhor definição tanto do processo de maturação desencadeado por soleiras de rochas básicas quanto do processo de acumulação de hidrocarbonetos junto aos diques de diabásio. Ou seja, conclui-se que a maturação iniciou-se na região desde as primeiras manifestações magmáticas da Reativação Pós-Paleozóica e que a acumulação ocorreu junto aos diques mais antigos e que provavelmente já estavam resfriados.

Ja as datações realizadas em afloramentos da porção central da Estrutura do Jacu (CC248 e CC252) forneceram idades $\mathrm{KJAr}$ da ordem de 129 a $131 \mathrm{Ma}$. Ao considerarmos a idade e o erro máximo da amostra mais jovem de $129 \pm 3 \mathrm{Ma}(\mathrm{CC} 248)$, verifica-se que a idade corresponde ao mesmo intervalo das datações ${ }^{40} \mathrm{Ar} /{ }^{39} \mathrm{Ar}$ que é de $134 \pm 2 \mathrm{Ma}$. O mesmo acontece com a amostra CC252, ou seja, as rochas intrusivas básicas encontradas no centro da Estrutura do Jacu têm aproximadamente a mesma idade dos diques associados aos arenitos asfálticos.

\subsection{Observações geológicas acerca da área de estudo}

A partir de observações de campo, percebeu-se que o posicionamento estratigráfico das ocorrências está no arenito Pirambóia preferencialmente próximo ao contato da Formação Teresina. A rocha armazenadora destas ocorrência é caracterizada por arenitos médios bem selecionados de grãos sub-arredondados a arredondados, foscos de deposição eólica apresentando estratificação cruzada de grande porte (métrica).

Estruturalmente, de sul para norte, a área de estudo é caracterizada por uma série de blocos altos, aparentemente homoclinais basculados para o norte, ou seja, blocos com mergulhos suaves para o norte e mergulhos abruptos na porção sul do bloco. Existem ocorrências associadas às zonas intermediárias e de baixos morfoestruturais. Na porção norte da área, as ocorrências de Porto Martins, Volta Grande, Betumita/Moquém e Piapara estão associadas às zonas de baixo 
morfoestrutural. As ocorrências na porção sul da área, Sobar, Itatigue, Nhaíva e Morro do Bofete encontram-se em áreas intermediárias entre um alto e baixos morfoestruturais. $O$ bloco sul é caracterizado por um alto morfoestrutural; uma feição de forma anelar e diâmetro aproximado de 20 $\mathrm{km}$. Seu limite sul é marcado pela presença de falhamentos radiais, do domo de Carlota Prenz, pelo soleira de Angatuba e pelo falhamento do Rio Guareí de direção NE. Seu limite norte é marcado pela presença de falhamentos radiais e pela Serra de Botucatu, além de falhamentos de direção NW.

Apesar da ênfase no estudo estrutural das ocorrências de arenitos asfálticos, é evidente a importância do alojamento do betume em determinadas fácies sedimentares da Formação Pirambóia. Notou-se a grande importância da fácies eólica como rocha armazenadora, ou seja, as dunas da base da Formação Pirambóia serviram de reservatório para os hidrocarbonetos. Já a fácies de interdunas pode estar relacionada como a armadilha horizontal, ou seja, como barreira à migração vertical dos hidrocarbonetos.

Nesse sentido, verifica-se que Briguetti (1994) identificou quatro grupos de fácies na Formação Pirambóia na Bacia do Paraná: dunas, interdunas, lençóis de areia e fluviais. Segundo Briguetti (1994), na base da formação, na proximidade com o contato da Formação Teresina, ocorrem depósitos tipicamente formados em regime eólico, caracteristicamente de dunas eólicas. Em toda a porção média e também em direção ao topo predominam depósitos de dunas e interdunas. Nestas últimas, são muito freqüentes as feições de interações flúvio/eólicas, onde cursos d'água erodem e depositam sedimentos previamente eólicos e cujos registros posteriormente, são em parte, retrabalhados pelo vento e redepositados por este. Já nas proximidades do contato com os sedimentos da Formação Botucatu, foram observados depósitos de dunas eólicas com predomínio de granulometria fina e alto grau de foscagem nos grãos.

Na verdade, as evidências encontradas na região conduzem a um raciocínio dual que engloba os seguintes fatores principais como controladores da gênese do arenito asfáltico na área: estrutural e estratigráfico.

A posição estratigráfica das ocorrências de arenito asfáltico (Fm. Pirambóia) juntamente com a idade da rocha geradora (calcários e folhelhos oleígenos do Subgrupo Irati) conduziu a uma definição de intervalo de tempo geológico/estratigrafia de interesse. Há interesse nos episódios geológicos ocorridos a partir da deposição, no Permiano, dos sedimentos da Subgrupo Irati e, mais especificamente, aos eventos e estruturas ocorridos entre o Triássico e o Cretáceo Inferior, ou seja, pós deposição dos arenitos Pirambóia até o início da deposição do Grupo Bauru.

Outro aspecto geológico importante, relacionado à ocorrência dos arenitos asfálticos, está associado à presença de diques de rochas básicas junto às ocorrências. Thomas Filho (1982) observou tal relação na ocorrência Betumita, a partir de sondagens na área de ocorrência. Os trabalhos de campo indicam tal associação em outras ocorrências como Nhaíva e Porto Martins onde os diques são aflorantes. Além disso, há evidências magnetométricas da presença de diques nas 
ocorrências Moquém, Morro do Bofete, Bairro da Mina, Estrada da Mina, Fazenda São Jorge e Itatigue. O papel dos diques de diabásio, na gênese das ocorrências, está relacionado principalmente a migração lateral dos hidrocarbonetos, os diques funcionaram como armadilhas verticais barrando o fluxo horizontal. Foi caracterizada uma idade de aproximadamente $134 \pm 2 \mathrm{Ma}\left({ }^{40} \mathrm{Ar} /{ }^{39} \mathrm{Ar}\right)$ para estes diques, ou seja, são elementos gerados do início para o meio do evento magmático. A datação geocronológica destas rochas indica que o óleo chegou em suas paredes tardiamente em relação ao início do magmatismo. Conclui-se que em relação à Reativação Pós-Paleozóica, a migração ocorreu tardiamente e os diques já estavam consolidados quando o óleo ficou preso.

A figura 4.67 apresenta um esquema dos principais componentes presentes na maioria dos afloramentos de arenito asfáltico e que resume as observações geológicas.

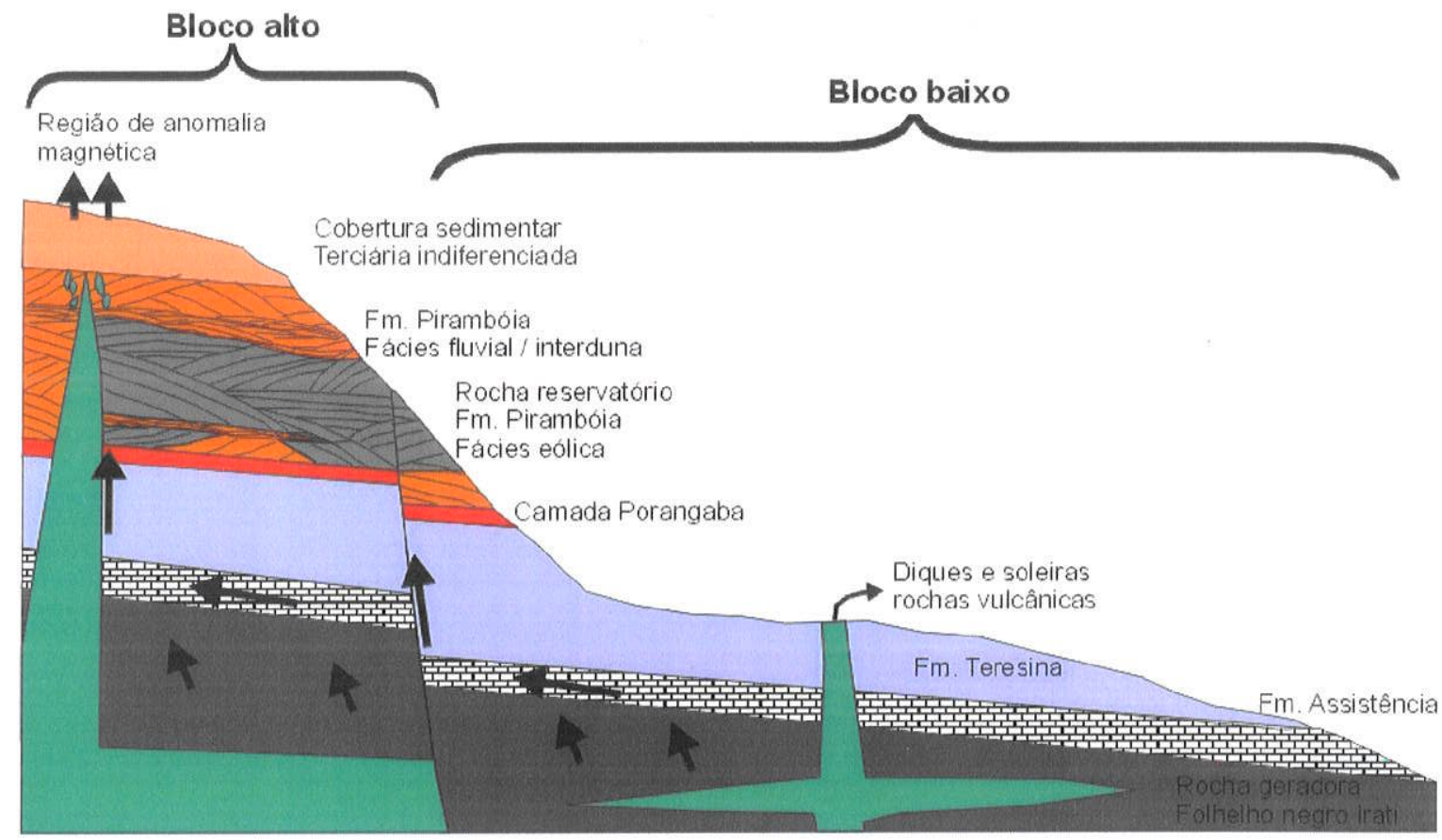

Figura 4.67: Principais elementos presentes nas ocorrências de arenito asfáltico e indicação dos principais caminhos de migração.

\subsection{Posicionamento espacial das ocorrências e o magmatismo associado}

Encontram-se diques de rochas básicas junto à área de afloramento do arenito betuminoso nas ocorrências do Morro do Bofete, Nhaíva, Porto Martins, Betumita Itatigue, Moquem, Bairro da Mina, Fazenda São Jorge e Estrada da Mina. Mais de $50 \%$ das ocorrências pesquisadas têm diques de rochas básicas associadas. Das cinco ocorrências onde foram feitos levantamentos magnetométricos e onde não havia diques aflorantes, três ocorrências apresentam anomalias 
magnéticas consistentes com a interpretação de diques de rochas básicas não aflorantes. Os diques de rochas básicas aflorantes têm textura média a fina. Esta textura é derivada do rápido resfriamento desses corpos ao intrudir as seqüências de rochas sedimentares, sua espessura é métrica e não ultrapassa $5 \mathrm{~m}$, conforme levantamento de campo. Mineralogicamente, são compostos por feldspato, piroxênio e olivina caracterizando-se pela presença de fenocristais de feldspato plagioclásio com grãos de até $2 \mathrm{~mm}$. Em geral, os feldspatos apresentam fissuras preenchidas por material de alteração provavelmente derivado de soluções quentes resultantes do final do processo de cristalização. Os feldspatos têm intensa alteração não intempérica, o aspecto dos grãos é fosco com cores amareladas e esbranquiçadas.

Estes diques são associados ao magmatismo Serra Geral. Em comum têm a pequena espessura, de ordem métrica e o posicionamento espacial junto às ocorrências e as idades correspondentes ao final do magmatismo.

O dique na ocorrência de Morro do Bofete tem direção N-N20E, de acordo com magnetometria de campo e fotointerpretação em imagem de satélite. Aparentemente, 0 dique preenche uma falha normal, porém o afloramento encontrado não permite detalhamento. A ocorrência de arenito asfáltico encontra-se somente do lado noroeste do dique. Também na região do Morro do Bofete, há um dique interpretado no Bairro da Mina de direção N40E; as ocorrências encontram-se no lado noroeste do dique.

$\mathrm{Na}$ ocorrência de Nhaíva foi possível medir a atitude do dique, N17E/vertical, com um comprimento aflorante de $55 \mathrm{~m}$. A ocorrência de arenito asfáltico encontra-se do lado noroeste, junto a parede do dique.

$\mathrm{Na}$ ocorrência de Porto Martins, encontrou-se um dique aflorante com direção N40W/vertical. Neste caso, a ocorrência de arenito asfáltico localiza-se na porção sudoeste do dique.

Franzinelli (1972) descreve a presença de diques de rochas básicas na ocorrência de Nhaiva, Morro do Bofete e Porto Martins. Segundo a autora, a migração do betume do Subgrupo Irati até os arenitos teria ocorrido devido à formação de capilaridade e/ou devido à pressão gerada pelas intrusivas básicas.

Não há dique aflorante na ocorrência Betumita. Thomaz Filho (1982) utiliza dados de sondagem e descreve a ocorrência de um dique de diabásio não aflorante de direção aproximada N20E/vertical. A ocorrência de arenito asfáltico está a nordeste e limitada pelo dique. O levantamento magnetométrico indica um dique de direção N-N10E.

Segundo Goulart \& Jardim (1982), em toda a Bacia do Paraná, há uma tendência das intrusões se alojarem em áreas de maior espessura de folhelhos, o que pode indicar uma preferência natural face aos planos de estratificação destes sedimentos.

No mapa aeromagnético da área de afloramento das ocorrências nota-se a tendência de alinhamento dos altos magnéticos de menor amplitude na direção NW, feição relacionada ao Arco de 
Ponta Grossa e alinhamentos estruturais como o de Guapiara, o qual foi estudado por Ferreira (1982).

A associação dos diques com as ocorrências de arenito asfáltico permite considerar as seguintes hipóteses:

- A intrusão de soleiras nas rochas geradoras, durante o magmatismo Serra Geral, causou a maturação local da matéria orgânica dos folhelhos Irati e a intrusão de diques propiciou uma caminho de migração secundária, fraturado, junto à parede do dique;

- O magmatismo ocorreu na forma de pulsos ao longo de aproximadamente $10 \mathrm{Ma}$, infere-se que estes pulsos propiciaram um mecanismo termal/tectônico que propiciou a migração.

Devido ao posicionamento das ocorrências, apenas de um lado dos diques, argumenta-se que os diques funcionam como barreiras laterais impermeáveis no caminho de migração dos hidrocarbonetos. A maturação ainda pode ser explicada pelo magmatismo Serra Geral, mas neste caso a migração ocorre tardiamente. Propõe-se que a maturação dos folhelhos negros Irati a partir da intrusão de soleiras, do aumento generalizado do grau geotérmico durante o magmatismo $e$ complementarmente por soterramento; embora, este último fator isoladamente não tivesse condições de sobrecarga para provocar a maturação. É importante ressaltar que, quase todas as ocorrências localizam-se a oeste dos diques de rochas básicas. Assim como, é importante notar que estas ocorrências estão próximos aos altos estruturais preferencialmente com os baixos estruturais à oeste. Nos mapas gravimétricos também notam-se ocorrências nas áreas de inflexão e com o baixos gravimétricos preferencialmente à oeste. Interpreta-se que o padrão de migração do óleo foi do centro da bacia para sua borda, os diques NE, no caso, foram as melhores barreiras no caminho de migração. Este padrão de migração provavelmente está relacionado às direções NW predominantes na área e também ao padrão hidrodinâmico da bacia durante a compactação dos pacotes sedimentares e expulsão da água. Além disso, é importante considerar as idades do magmatismo que indicam direção de magmatismo NW-SE, com idades mais antigas na porção centro noroeste da bacia e mais jovens na porção sudeste.

\subsection{Gênese dos arenitos asfálticos}

O modelo para a gênese das ocorrências de arenito asfáltico envolve diversos elementos geológicos. Entre estes elementos, destacam-se o fator de geração relacionado as rochas geradoras do Subgrupo Irati; o fator de acumulação relacionado às rochas reservatório da Fm. Pirambóia e secundariamente $\mathrm{Fm}$. Tatuí; e finalmente o fator de migração/acumulação que relaciona-se aos caminhos de migração, estruturas acumuladoras e cronologia de eventos. A Figura 4.68 apresenta esquematicamente os principais elementos e processos relacionados à gênese do arenito asfáltico. 

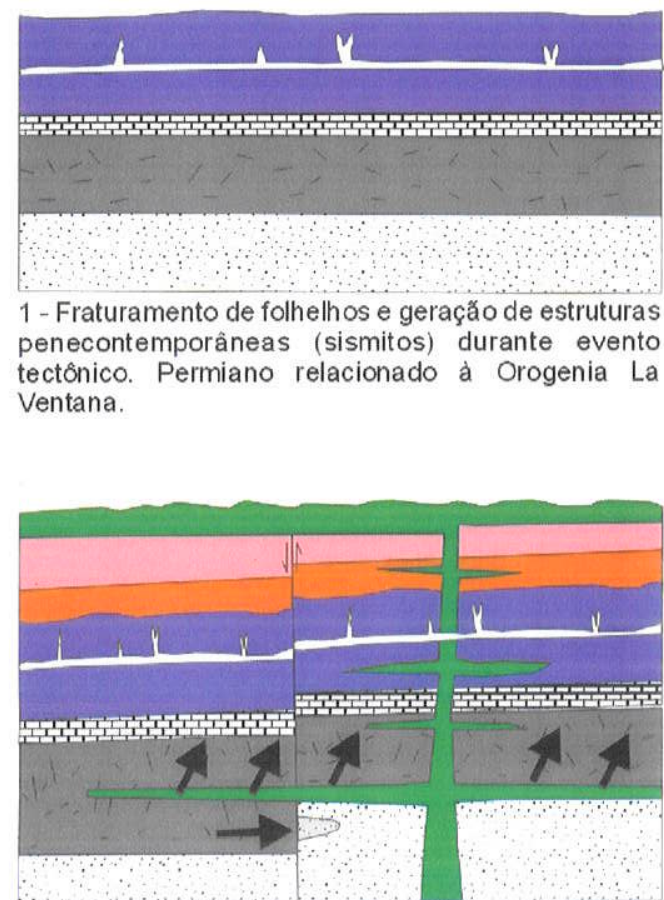

3 - Maturação da matéria orgånica e migração primária a partir do aumento anômalo do gradiente geotérmico.
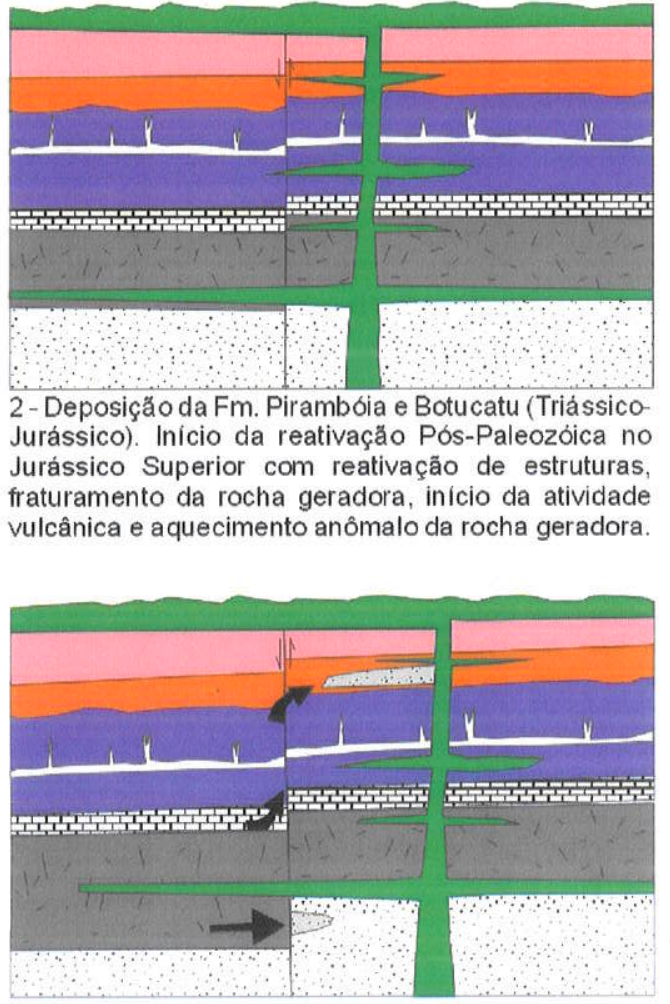

4 - Migraçăo secundária aolongo de falhas e diques de rocha básica e camadas permeáveis basculadas. Fluxo em direção aos altos estruturais. Acumulaçăo sob camadas de baixa permeabilidade e junto a paredes de diques.

Figura 4.68: Principais elementos relacionados à gênese do arenito asfáltico.

A seguir, apresenta-se os principais elementos relacionados aos estágios de migração e acumulação:

1. Geração de zonas de fraqueza permianas e triássicas na região e reativação de estruturas do embasamento.

Estruturas penecontemporâneas como diques clásticos encontrados na Fm. Teresina indicam atividade tectônica na área desde o Permiano que fraturaram as rochas geradoras e geraram zonas de fraqueza, além de reativar estruturas do embasamento.

Atividade tectônica Triássica e do início do Jurássico também fraturou a rocha geradora, reativou as zonas de fraqueza do embasamento e estruturas geradas no Permiano.

2. Início do magmatismo - Jurássico Superior (Tithoniano).

No Jurássico Superior houve as primeiras intrusões de rochas vulcânicas básicas. Neste período, houve aquecimento anômalo da rocha geradora de acordo com a intrusão de soleiras de rocha básica e aumento generalizado do gradiente geotérmico. Este aquecimento propiciou a 
maturação anômala da matéria orgânica e fraturamento da rocha geradora. Durante estes eventos iniciou-se a migração primária. Também há diques de rochas básicas desta idade (aproximadamente $134 \mathrm{Ma}$ ) associados às ocorrências de arenito asfáltico. Provavelmente nesta época iniciou-se a geração dos altos estruturais como o de Anhembi e Carlota Prenz.

\section{Migração secundária - Cretáceo Inferior (Berriasiano)}

Migração secundária através de zonas antigas de fraqueza e descontinuidades geradas durante os primeiros estágios da Reativação Pós-Paleozóica. Dois fatores principais afetaram a migração secundária: um fator estratigráfico e um fator estrutural. $O$ fator estrutural relaciona-se a uma forte contribuição tectônica, de acordo com o desenvolvimento de altos estruturais, permitindo a migração das regiões de baixo estrutural em direção ao centro dos altos estruturais e geração de caminhos de migração em zonas de falha e limites de blocos tectônicos. O fator estratigráfico diz respeito ao posicionamento da maioria das ocorrências, que estão posicionadas preferencialmente na porção basal da Fm. Pirambóia. Isto ocorre provavelmente pela variação de permeabilidade dada pela presença de fácies eólicas, fácies de interdunas e fluviais. Além disso, considera-se que as características de maturidade juvenil e baixa viscosidade dos hidrocarbonetos também contribuiu para o aprisionamento dos hidrocarbonetos.

\section{Acumulação}

A acumulação ocorreu preferencialmente em arenitos eólicos da base da Formação Pirambóia ao longo dos planos de estratificação e sob camadas de matriz argilosa das fácies de interduna. Além disso, a acumulação ocorreu junto à parede de diques onde houve interrupção do fluxo horizontal, estes diques de rocha básica foram datados do Jurássico Superior. A acumulação ocorreu preferencialmente junto aos diques NE num padrão de fluxo centrífugo em relação às porções mais profundas da bacia e aos baixos estruturais. Entretanto, há pelo menos uma acumulação junto a diques de direção NW. Infere-se que os diques de direção NE estejam relacionados à direção de fraquezas do embasamento e correspondem ao início do magmatismo. Durante a migração secundária, estes diques de direção NE já estavam consolidados e resfriados. Infere-se que os caminhos de migração principal estejam relacionados as falhas de direção NW e que dessa forma o fluxo foi preferencialmente interrompido por estruturas selantes NE. Estas estruturas NW, assim como os diques de direção NW correspondem à fase de maior atividade tectono-magmática da Reativação Pós Paleozóica que ocorreu durante o início do Cretáceo.

\section{Posicionamento espacial e morfológico das acumulações}

As ocorrências de arenito asfáltico estão em bordas de altos estruturais provavelmente de idade Juro-Cretácea. A migração ocorreu em direção aos altos estruturais e considera-se que os 
hidrocarbonetos tenham atingido as rochas reservatório presentes no topo destas estruturas. Estes altos estruturais foram posteriormente erodidos em um processo provavelmente iniciado no final do Cretáceo e que perdura até hoje. Desse modo, considera-se que o topo dos altos estruturais foram erodidos $e$ as acumulações destruídas. As ocorrências encontradas estão em terrenos remanescentes preservados da erosão em porções intermediárias entre os altos e baixos estruturais. Este padrão é verificado tanto nas ocorrências da área de Anhembi quanto nas ocorrências da área do Jacu.

O fator tempo implícito na cronologia dos eventos descritos anteriormente é essencial para a explicação da gênese dos arenitos asfálticos. Considera-se que houve contemporaneidade entre os eventos de geração/migração e a acumulação dos hidrocarbonetos dentro de um período de aproximadamente $10 \mathrm{Ma}$, correspondente ao evento tectono-magmático da Reativação Paleozóica.

Entretanto, esta contemporaneidade de eventos provavelmente causou perda de hidrocarbonetos por falta de sincronismo, ou seja, ocorrência de fluxo de hidrocarbonetos na rocha reservatório sem a geração de estruturas armazenadoras como soleiras de diabásio, por exemplo. Neste caso, nota-se que predominantemente há armazenamento em função das condições de permeabilidade da rocha armazenadora. Nos afloramentos de arenito asfáltico, é possível observar este fato no aspecto listrado e irregular provocadas pelo preenchimento do óleo nas estratificações cruzadas de origem eólica. Além disso, todas as ocorrências eram formadas por fácies eólica, não foram encontradas ocorrências associadas aos depósitos fluviais ou fácies de interduna.

Há de se considerar a possibilidade de armadilhas estruturais. Entretanto, segundo Araújo et al. (2000), a contemporaneidade do processo de geração-migração com a fase de formação de trapas estruturais (durante o rifteamento do Gondwana) diminui o potencial das Formações Pirambóia e Botucatu para armazenar petróleo devido às incertezas associadas ao sincronismo entre os eventos. Baseados nesta premissa, os autores definem que há maior chance de armazenamento nas estruturas originadas no evento Cabo-La Ventana. Entretanto, na área de estudo, as principais estruturas associadas às ocorrências de arenitos asfálticos são os Altos Estruturais de Anhembi e Carlota Prenz e estruturas menores como o alto da Areia Branca, Quebra e Morro do Bofete. Estas estruturas são originadas principalmente pelos eventos da Reativação Pós-Paleozóica e seu papel relaciona-se à migração dos hidrocarbonetos, na forma de falhas condutoras, e à acumulação, na forma de camadas basculadas e diques trapeadores. Desse modo, adotou-se o diagrama de eventos do Sistema Petrolífero Irati-Pirambóia proposto por Araújo et al. (2000) com modificações que permitem explicar a seqüencia de eventos relacionadas às ocorrências de arenito asfáltico da área de estudo. A Figura 4.69 mostra o quadro de eventos dos elementos relacionados a gênese de arenitos asfálticos da borda leste da Bacia do Paraná. Comparativamente, a Figura 4.70 mostra o diagrama de eventos para o sistema Irati-Pirambóia de Araújo et al. (2000). 


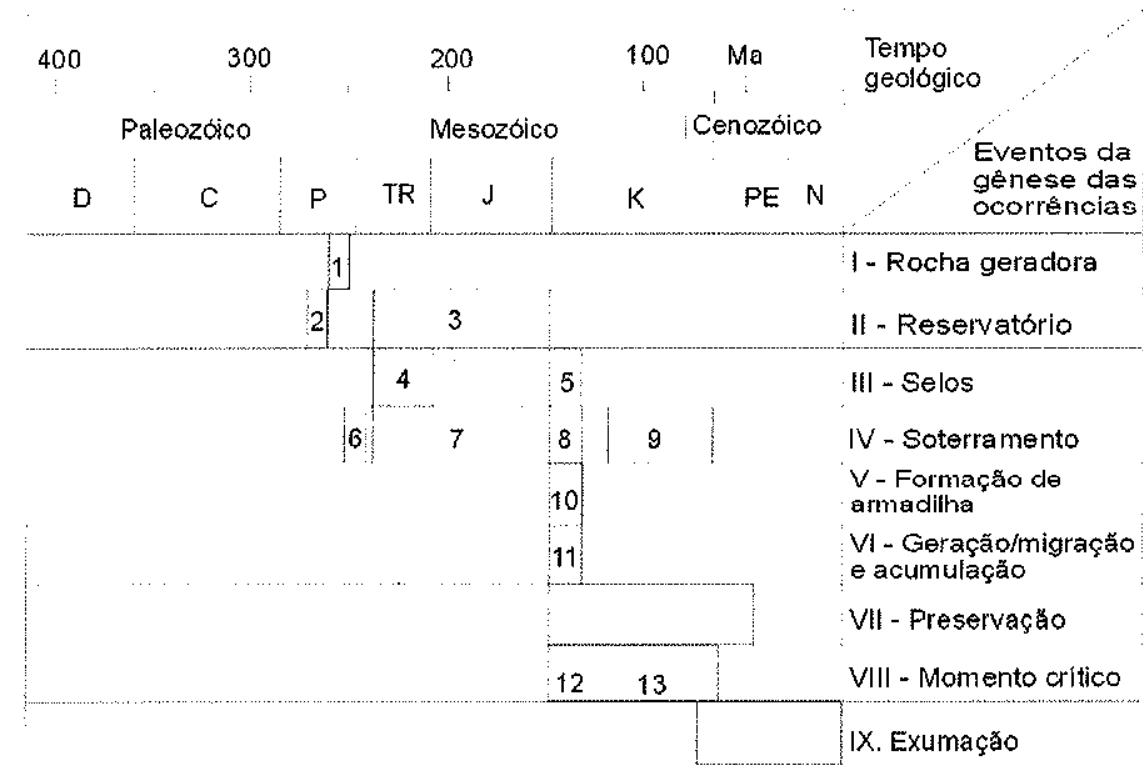

Eventos

I. Rocha geradora

1. Fm. Assistência (Kazaniano)

II. Reservatórios

2. Fm. Tatui

3. Fm. Pirambóia e Botucatu

III. Selos
4. Fm.Pirambóia - fácies fluvial fácies eólica (interduna)

5. Fm. Serra Geral

IV. Soterramento

6. Pormiano Supelior - Triássico Inferio

7. Triássico Superior-Jurássico

8. Cretáceo Inferior

9. Cretáceo Superior

V. Formaçăo da armadiltia

10. Fase de rifteamento

VI. Geraçăo/migraçăo e

acumulaçắ

11. Efeito termal de rochas

igneas intrusivas

VII. Preservaçăa

VIII. Momentos criticos

12. Reativaçăo Pós-Paleozóica

13 Soerguimento no Cretáceo SuperiorCenozóico.

IX. Exumaçăo

Figura 4.69: Quadro de eventos - arenitos asfálticos. Principais elementos e cronologia relacionados a gênese dos arenitos asfálticos na borda leste da Bacia do Paraná (Adaptado a partir de Araújo et al. 2000).

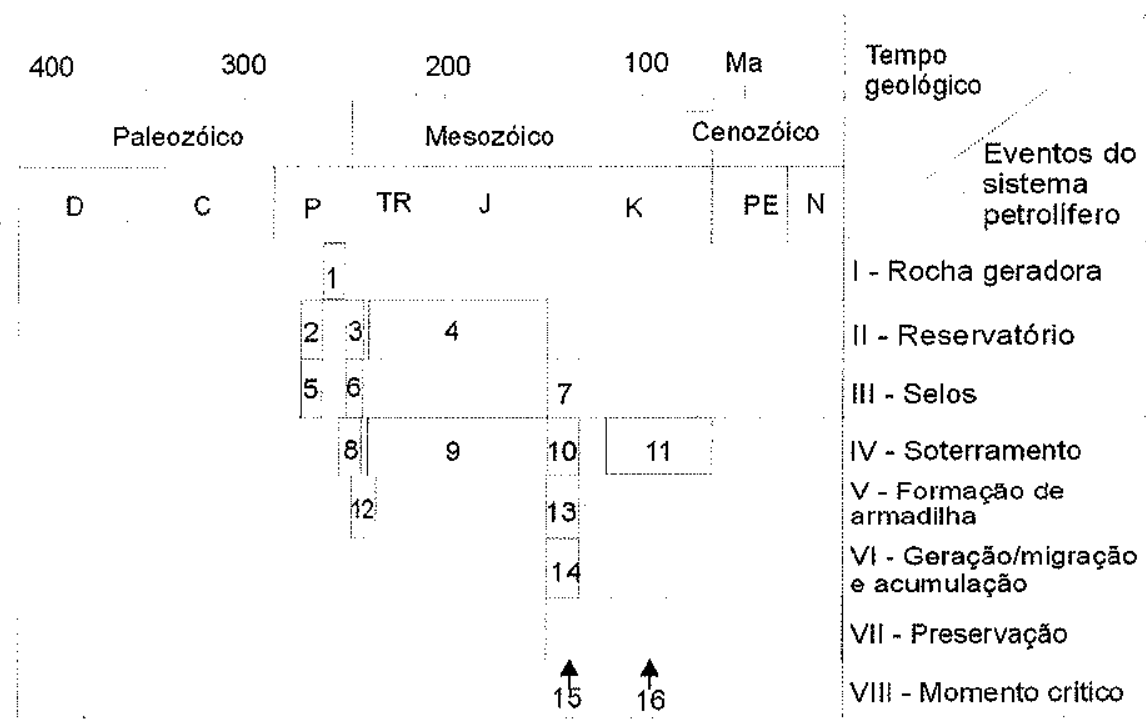

Eventos

I. Rocha geradora

1. Fm. Assistência (Kazaniano)

II. Reservatórios

2. Fim. Palermo e Rio Bonito

3. Fm. Teresina e Rio do Rasto

4. Fm. Pirambóia e Botucatu

III. Selos
5. Fm. Palermo e Rio Bonito
6. Fm. Teresina e Rio do Rasto
7. Fm. Serra Geral

IV. Soterramento

8. Permiano Superior - Triássico Inferio

9. Triássico Superior-Jurássico

10. Cretáceo Inferior

11. Cretáceo Superior

V. Formação da armadilha

12. Orogenia La Ventana

13. Fase de rifteamento

VI. Geração/migração e

acumulação

14. Efeito termal da rochas igneas intrusivas

VII. Preservação

VIII. Momentos críticos

15. Fase de rifteamento

16 Soerguimento no Cretáceo SuperiorCenozóico.

Figura 4.70: Quadro de eventos - Sistema petrolifero Irati-Pirambóia. Relações dos elementos e processos essenciais, assim como o tempo de preservação e momentos críticos do sistema petrolifero Permiano da Bacia do Paraná (Retirado de Araújo et al. 2000). 
A seguir são discutidos aspectos levantados no objetivo da pesquisa e cujas respostas auxiliam o entendimento da gênese dos arenitos asfálticos.

\section{As ocorrências são caracterizadas como reservatório exumados ou exsudações (oil seeps)?}

O posicionamento estratigráfico das ocorrências conduz à consideração que as ocorrências de arenitos asfálticos são reservatórios exumados. Os hidrocarbonetos possivelmente migraram para os arenitos sob condições de soterramento. Não há evidências de exudações em rochas Terciárias ou Quaternárias. Além disso, o reservatório Pirambóia está diretamente sobre os siltitos e lamitos pouco permeáveis da Formação Teresina. Houve uma migração horizontal de hidrocarbonetos nos arenitos triássicos Pirambóia em função da presença de camadas intercaladas de lamito e das variações verticais das condições de porosidade-permeabilidade. Estas camadas agiram como barreiras horizontais, que impediram ou dificultaram a migração vertical. Não são encontradas quaisquer ocorrências na Formação Botucatu, Jurássico. Entretanto, na Formação Botucatu há boas condições de porosidade e permeabilidade. Por outro lado, foi encontrada uma ocorrência nos arenitos da Formação Tatui, Permiano. Na verdade, esta ocorrência resulta de falhamento, o qual colocou os arenitos da Formação Tatuí ao lado dos folhelhos negros do Subgrupo Irati.

\section{Qual o papel do magmatismo Serra Geral na gênese das ocorrências?}

O magmatismo Serra Geral está relacionado a geração (Simoneit et al. 1978a e b) e também a migração e acumulação. Considerando um intervalo de 10 a 12 Ma para o magmatismo Cretáceo (Stewart et al. 1996) é possível considerá-lo como o responsável por todo o processo de gênese do arenitos asfáltico. Soleiras de diabásio do início do magmatismo causaram aquecimento anômalo nas camadas ricas em matéria orgânica do Subgrupo Irati. Eventos tectônicos do início do magmatismo causaram a reativação de lineamentos antigos e fraturaram os folhelhos negros causando a migração primária. Diques do início do magmatismo intrudiram estruturas NE principalmente e o aumento das condições de pressão e temperatura por $10 \mathrm{Ma}$ aproximadamente propiciou a maturação. Finalmente, a acumulação de hidrocarboneto ocorreu, mais tarde, junto às paredes de diques e sob camadas argilosas quando as rochas básicas já estavam cristalizadas. Este modelo considera um intervalo de tempo restrito a $10 \mathrm{Ma}$ entre a geração e a acumulação, além de considerar a idade ${ }^{40} \mathrm{Ar} /{ }^{39} \mathrm{Ar}$ de $134 \pm 2$ Ma obtida em diques e soleiras na área de estudo.

\section{Quais elementos geológicos compõem o processo de migração?}

A explicação dos processo de migração e acumulação está relacionada à presença de diques de rochas básicas, falhamentos e posicionamento estratigráfico. A migração primária ocorreu de acordo com o intenso fraturamento dos folhelhos negros Irati (Araújo et al., 2000). A migração secundária está relacionada aos limites de blocos tectônicos: mais precisamente falhas, diques e 
zonas de juntas gerados em diversos pulsos tectono-magmáticos durante a Reativação PósPaleozóica. A intersecção de zonas de falhamento são especialmente importantes para o processo de migração secundária. Estruturas antigas NE, reativadas a partir do embasamento, são cruzadas por estruturas mais jovens NW relacionadas ao magmatismo Cretáceo. A interseç̧ão de zonas de falha forma áreas de dilatação com tensões cisalhantes relativamente pequenas (Gartrell et al. 2003) adequadas para a migração de hidrocarbonetos.

\section{Como explicar o pósicionamento estratigráfico das ocorrências?}

A maioria das ocorrências está localizada na base da Fm. Pirambóia e uma delas localiza-se na Formação Tatuí. A acumulação preferencialmente na base da Fm. Pirambóia ocorreu em função das condições de baixa permeabilidade dos depósitos de interduna e da fácies fluvial da Fm. Pirambóia conjugadas com a alta viscosidade dos hidrocarbonetos cuja maturação foi anômala.

$\mathrm{Na}$ área de estudo notam-se importantes falhas verticais e presença de altos e baixos estruturais que possibilitaram a aproximação entre a rocha geradora e a reservatório. Além disso, as falhas configuraram-se como caminhos de migração. Desse modo, a presença de óleo em arenitos da Fm. Tatuí é um exemplo do soerguimento destas rochas que foram colocadas próximas à rocha geradora, ou seja, a acumulação na Fm. Tatuí encontra-se em um bloco alto.

Interpreta-se que a migração do sistema Irati-Pirambóia é caracterizada na área como de alta impedância e drenagem (migração) principalmente vertical. Ou seja, sistemas petrolíferos de alta impedância podem ser discriminados a partir de algumas características (Demaison \& Huizinga, 1994); entre elas, destaca-se que quase todas as acumulações ocorrem sobre ou próximo a área da rocha geradora. A distância de migração lateral é pequena (geralmente menor que $30 \mathrm{~km}$ ). Além disso, várias acumulações em rochas reservatório de idades diferentes contêm óleo do mesmo tipo genético.

\section{Como são caracterizadas as armadilhas nas ocorrências?}

As armadilhas são caracterizadas por elementos verticais que são os diques de rochas vulcânicas e por elementos horizontais. As armadilhas horizontais são compostas por depósitos de interdunas e fácies fluvial da Fm. Pirambólia cujas variações de permeabilidade causam o trapeamento. Além disso, as condições de alta viscosidade dos hidrocarbonetos os faz susceptiveis a estas variações de permeabilidade o que aumenta eficiência dos depósitos de interdunas e fácies fluviais como armadilhas.

Qual a cronologia dos eventos que compöem o modelo de geração, migração e acumulação?

- sistema petrolífero Irati-Pirambóia é Permiano de acordo com a rocha geradora. É importante considerar não somente a Reativação Pós-Paleozóica, mas também os eventos tectônicos 
permianos como relacionados à gênese do arenito asfáltico. A orogenia Cabo-La Ventana causou a reativação de estruturas do embasamento e o desenvolvimento de novas fraturas nas rochas da bacia. Este evento causou uma rede de fraturamento na rocha geradora, permitindo a futura migração primária. Além disso, com o início da Reativação Pós-Paleozóica, estas áreas de fraqueza funcionaram como caminhos para a migração de hidrocarbonetos, especialmente nas áreas de cruzamento das direções NW e NE. A intensa atividade vulcânica do início do Cretáceo propiciou a maturação anômala da matéria orgânica e a formação de armadilhas verticais na forma de diques de rochas básicas.

Qual é o modelo geral para a gênese de arenitos asfálticos? Há apenas um modelo? Todas as ocorrências foram geradas segundo o mesmo modelo?

Considera-se que todas as ocorrências estejam relacionadas aos eventos descritos anteriormente. Os elementos básicos já descritos são a presença de rocha geradora permiana, maturação anômala e migração a partir de eventos tectono-magmáticos decorrentes da Reativação Pós-Paleozóica e finalmente acumulação em arenitos da Fm. Pirambóia e Tatuí.

A maior parte das ocorrências associam-se a diques NE, outras a diques NW. A principal diferença entre as ocorrências está relacionada à direção dos diques associados. A interpretação de lineamentos nas imagens de sensoriamento sugere que os diques NW sejam mais jovens que os de direção NE. Além disso, a estruturação NE do embasamento sugere que esta seja uma direção de fraqueza preferencial para a entrada dos primeiros corpos intrusivos. Entretanto, a datação obtida junto a um dique NW (ocorrência de Porto Martins), com uma idade ${ }^{40} \mathrm{Ar} /{ }^{39} \mathrm{Ar}$ de $134 \pm 2 \mathrm{Ma}$, sugere que os diques NE e NW têm a mesma idade. Infelizmente, as datações dos diques NE não foram bem sucedidas para confirmar definitivamente se o óleo acumulou-se em diques de mesma idade e de direções diferentes. Esta é uma evidência que o modelo geral é o mesmo para todas as ocorrências, com um tempo de migração semelhante. 


\section{CAPITULO 5}

\section{CONSIDERAÇÕES FINAIS}

Os trabalhos de reconhecimento de campo, geofísica e análises geocronológicas permitiram o melhor entendimento dos fatores relacionados à gênese das ocorrências de arenito asfáltico no sistema petrolifero Irati-Pirambóia. Foram definidos fatores estratigráficos e estruturais e suas relações temporais como fundamentais para a acumulação de hidrocarbonetos na área de estudo. $\mathrm{A}$ definição e compreensão do papel destes fatores em uma área de afloramento da borda da bacia contribui para a pesquisa em porções profundas da Bacia do Paraná.

\subsection{Conclusões}

Os levantamentos gravimétricos e magnetométricos auxiliaram na definição do arcabouço estrutural da área. A área do Jacu é caracterizada como uma região de baixo gravimétrico com um espesso pacote sedimentar circundado por intrusões vulcânicas. Isto resultou em uma anomalia de drenagem anelar bem definida. A interpretação morfoestrutural empregada permitiu o mapeamento dos principais blocos tectônicos e seus limites. Também permitiu a análise da estrutura do Jacu, que é caracterizada como de origem geomorfológica, relacionada às direções NW e NE.

A distribuição espacial das ocorrências de arenito asfáltico na área de estudo está diretamente relacionada aos elementos geológicos condicionantes. Entretanto, os processo erosivos atuantes na região foram fundamentais para a exposição dos afloramentos. Estes processos erosivos são reconhecidos nas características geomorfológicas da área de ocorrência caracterizada pelo domínio da paisagem de depressão geomorfológica.

Desse modo, considera-se que as ocorrências de arenito asfáltico estão diretamente relacionadas a condicionantes estratigráficos e estruturais, mas o processo denudacional é também considerado fundamental para a exposição das ocorrências. De um modo geral, os principais elementos do fator estratigráfico e estrutural são relacionados e estão no mapa de contorno estrutural: as ocorrências estão localizadas nos flancos de altos estruturais e localizadas a poucos metros do contato Teresina-Pirambóia, que é um importante parâmetro estratigráfico. Nos afloramentos, a presença de camadas argilosas na base da Formação Pirambóia age como uma barreira a migração vertical de hidrocarbonetos. Além disso, a migração horizontal seguiu a direção do plano de acamamento dos arenitos Pirambóia (estratificação cruzada eólica).

O fator estrutural está relacionado aos lineamentos interpretados em imagens de satélite, na rede de drenagem e no MNT: as ocorrências estão localizadas perto dos principais lineamentos estruturais, especialmente na intersecção de falhas NW e NE. Fraturas de extensão relacionadas a 
falhas NW também são elementos importantes para a migração de óleo. Estas descontinuidades agem como condutos para a migração do óleo, mas as falhas também agem como selos, especialmente aquelas com fraturamento na mesma direção de deslocamento do movimento. A geração de falhas está relacionada a antigas zonas de fraqueza incluindo as estruturas do embasamento, eventos Permianos e a Reativação Pós-Paleozóica. É inferido que as falhas transportaram hidrocarbonetos por dezenas de metros verticalmente e poucos metros lateralmente. $A$ migração lateral ocorreu principalmente ao longo dos planos de estratificação.

Considerando as ocorrências observadas e a alta permeabilidade dos arenitos Pirambóia. É muito importante a contribuição das variações de permeabilidade nas bandas de deformação para a migração de hidrocarbonetos, que segmentam o reservatório. Entretanto, não é descartada a importância das fraturas no aumento da migração no reservatório e sua produção.

O elemento chave na área de estudo é a presença de diques de rochas básicas associados às ocorrências de arenitos asfálticos. Além disso, as ocorrências estão em áreas de alto magnético. Esta assinatura magnética é interpretada como derivada da presença de corpos básicos intrusivos. 0 magmatismo agiu nos estágios de geração, migração e acumulação. O magmatismo que gerou as armadilhas verticais (diques) ocorreu principalmente no periodo inicial da Reativação Pós-Paleozóica, diques e soleiras foram datados ${ }^{40} \mathrm{Ar} /{ }^{39} \mathrm{Ar} 134 \pm 2 \mathrm{Ma}$, assim como o aumento da temperatura que provocou o início da maturação e geração de óleo imaturo. Já a chegada do óleo no reservatório ocorreu tardiamente durante os estágios finais do magmatismo, quando as armadilhas verticais já estavam consolidadas. 


\section{REFERÊNCIAS BIBLIOGRÁFICAS}

ABOARRAGE, A.M; LOPES, R.C. (coords). (1986) Projeto Borda Leste da Bacia do Paraná: Integração geológica e avaliação econômica. Convênio CPRM-DNPM, CPRM SUREG-SP.

AB'SABER, A.N. (1969) A depressão periférica paulista: um setor das áreas de circundesnudação pós-cretácea na Bacia do Paraná. São Paulo, IGEO-USP, Geomorfologia 15, 11p.

ALMEIDA, F.F.M. (1964) Fundamentos geológicos do relevo paulista. Boletim do I.G.G., v.41, p.167.

ALMEIDA, F.F.M. (1967) Origem e evolução da plataforma brasileira. Boletim da Divisão de Geologia e Mineralogia, DNPM, v. 241, p. 1-36.

ALMEIDA, F.F.M \& CARNEIRO, C.D.R. (1989) The igneous record of the mesozoic activation of South American Platform. Geotectonica et Metallogenia, v.13, p. 308-325.

ALIYEV A. (1979) Regional fracturing of the Pamirs and its metallogenic significance. Doklady Akad. Nauk, USSR, v. 250, p. 90-93.

ANDRADE, S.M.; SOARES, P.C. (1971) Geologia de Semi-detalhe no centro leste de São Paulo. Rio de Janeiro, Petrobrás, DESUL, relatório n. 407, 52 p.

ANTONELLINI, M.A.; AYDIN, A.; POLLARD, D.D. (1994) Microstructure of deformation bands in porous sandstones at Arches National Park, Utah. Journal of Structural Geology, v. 16, n. 7, p. 941-959.

ARAÚJO, L.M.; TRIGUIS, J.A.; CERQUEIRA J.R.; FREITAS L.C. DA S. (2000) The atypical Permian Petroleum System of the Paraná Basin, Brazil. In M.R. Mello \& B.J. Katz (eds.) Petroleum systems of South Atlantic margins. AAPG Memoir v. 73, p. 377-402.

AYDIN, A. (1978) Small faults formed as deformation bands in sandstone. Pageoph, v.116, p. 913930.

AYDIN, A.; JOHNSON, A.M. (1983) Analysis of faulting in porous sandstones. Journal of Structural Geology, v. 5, n. 1, p. $19-31$.

BEISL, C.H. (1996) Integração de dados de sensoriamento remoto, geologia, gravimetria e topografia para o estudo do arcabouço estrutural em uma parte do compartimento nordeste da bacia do Recôncavo. São José dos Campos, 109 p. (Dissertação - Mestrado) - Instituto Nacional de Pesquisas Espacias.

BRIGUETTI, J.M.P. (1994) Faciologia dos sedimentos da Formação Pirambóia na região de Rio Claro (SP). Rio Claro, 124 p. (Dissertação de Mestrado) - Instituto de Geociências e Ciências Exatas, UNESP.

CAETANO-CHANG, M.R. (1997) A Formação Pirambóia no Centro-Leste do Estado de São Paulo. Rio Claro, 196 p. (Tese - Livre-Docência) - Instituto de Geociências e Ciências Exatas, UNESP.

CHAMANI, M.A.C.; MARTIN, M.A.B.; RICCOMINI, C. (1992) Estruturas de liqüefação induzidas por abalos sísmicos no permomtriássico da Bacia do Paraná, Estado de São Paulo, Brasil. In: CONGRESSO BRASILEIRO DE GEOLOGIA, 37, São Paulo. Boletim de Resumos Expandidos. São Paulo, SBG, v. 2, p.508-510.

CHRISTIE-BLICK N. \& BIDDLE K.T. (1985). Deformation and basin formation along strike-slip faults. In K.T. Biddle \& N. Christie-Blick (eds.) Strike-slip deformation, basin formation, and sedimentation. Society of Economic Paleontologists and Mineralogists Special Publication No. 37, 1-34.

CNP. (1944) Relatório de 1944. Rio de Janeiro, CNP, 280 p. 
COBBOLD P.R.; MASSABIE A.C.; ROSSELLO E.A. (1986) Hercynian wrenching and thursting in the Sierras Australes foldbelt, Argentina. Hercynica, n. 2, p. 135-148.

COBBOLD, P.R.; GAPAIS, D. \& ROSSELO, E.A. (1991) Partioning of transpressive motions within a sigmoidail foldbelt: The Variscan Sierras Australes, Argentina. Joumal of Structural Geology, v. 13, p. 743-758.

COBBOLD P.R.; ROSSELLO E.R.; MILANI E.J.; SZATMARI P. (1992) Permo-Triassica intracontinental deformation in SW Gondwana. In: de Wit \& Randsome (eds), Inversion Tectonics of the Cape Fold Belt, Karoo and Cretaceous Basins of Southern Africa. Rotterdam, Balkema, p.23-26.

COIMBRA A.M.; BRANDT NETO M.; PETRI, S. (1977) O alinhamento estrutural do Tietê. In: SIMPÓSIO DE GEOLOGIA REGIONAL, São Paulo, 1977, SBG, p. 145-152.

COLLON A. (1897) Le petrole dans les environs du Mont de Bofete et de Porto Martins, dans l'Etat de São Paulo. Instituto Geográfico e Geológico, Secretaria de Agricultura do Estado de São Paulo, $69 \mathrm{p}$.

CPRM - Companhia de Pesquisa de Recursos Minerais. (2001a) Mapa Geológico do Brasil. Rio de Janeiro. (Escala 1:2.500.000). CD-ROM.

CPRM - Companhia de Pesquisa de Recursos Minerais. (2001b) Mapa Tectônico do Brasil. Rio de Janeiro. (Escala 1:2.500.000). CD-ROM.

CREPANI E. (1987) Análise de fraturas através de imagens fotográficas de baixa resolução espacial: uma contribuição ao estudo da evolução tectônica da região da Chapada do Araripe - NE do Brasil. São Paulo, 139 p. (Tese - Doutorado) - Instituto de Geociências, Universidade de São Paulo.

DAEE-UNESP. (1984) Landim, P.M.B. (coordenador), Mapa Geológico do Estado de São Paulo, escala 1:250.000 - Folha Botucatu.

DAEE-UNESP. (1984) Landim, P.M.B. (coordenador), Mapa Geológico do Estado de São Paulo, escala 1:250.000 - Folha Campinas.

DAVIS, G.H.; BUMP., A.P.; GARCÍA, P.E.; AHLGREN, S.G. (1999) Conjugate Riedel deformation band shear zones. Journal of Structural Geology, v.22, p. 169-190.

DEMAISOM, G.; HUIZINGA, B.L. (1994) Genetic classification of petroleum systems using three factors: charge, migration, and entrapment. In: Magoon, L.B. and W.G. Dow (eds.), 1994, The petroleum system - from source to trap: AAPG Memoir 60.

FERNANDES, L.A. \& COIMBRA, A.M. (1993) Registros de episódios sísmicos na parte superior da Formação Rio do Rasto no Paraná, Brasil. In: SIMPÓSIO DE GEOLOGIA DO SUDESTE, 3, Rio de Janeiro. Atas. Rio de Janeiro, SBG/UERJ, p.271-275.

FERREIRA F.J.F.; MORAES R.A.V.; FERRARI M.P.; VIANNA R.B. (1981) Contribuição ao estudo do alinhamento estrutural de Guapiara. In: Simpósio Regional da Geologia, 3, Curitiba, 1981 Atas, SBG, v. 1, p. 226-240.

Ferreira F.F.J. 1982. Integração de dados aeromagnéticos e geológicos:configuração e evolução tectônica do Arco de Ponta Grossa. Inst. de Geociências, Universidade de São Paulo, São Paulo, Dissertação de Mestrado, 169 p.

FOSSEN, H. (1997) Geometric Analysis and scaling relations of deformation bands in porous sandstone. Journal of Structural Geology, v. 19, n.12, p.1479-1493.

FRANZINELLI, E. (1972) Arenitos asfálticos do estado de São Paulo. São Paulo, 104 (Tese Doutorado) - Instituto de Geociências, Universidade de São Paulo. 
FÚLFARO, V.J. (1967) Contribuição à geologia da região de Angatuba, Estado de São Paulo. São Paulo, 91 p. (Tese - Doutorado) - Instituto de Geociências, Universidade de São Paulo.

FúlfFARO, V. J.; Saad, A. R.; Santos, M. V.; Vianna, R. B. (1982) Compartimentação e evolução tectônica da Bacia do Paraná. Revista Brasileira de Geociências, v.12, p. 590-611.

FÚlFARO, V.J.; SAAD, A.R.; PERINOTTO, J.A.J.; ETCHEBEHERE, M.L.C. (1997) Paraná Basin: Mineral Resource Potentials in Brazil, Uruguay, and Paraguay. Intemational Geology Review, v. 39 p. 703-722.

GARTRELL, A.; ZHANG, Y.; LISK, M.; DEWHURST, D. (2003) Enhanced hydrocarbon leakage at fault intersections: an example from the Timor Sea, Northwest Shelf, Autralia. Joumal of Geochemical Exploration, v.78-79, p. 361-365.

GOULART, E.P.; JARDIM, N.S. (1982) Avaliação geoquímica das formações Ponta Grossa e Irati Bacia do Paraná. In: Geologia da Bacia do Paraná - Reavaliação da Potencialidade e Prospectividade em Hidrocarbonetos. São Paulo, Paulipetro/CESP/IPT, p. 41 - 74.

GUNN, P.J.; MAIDMENT, D.; MILLIGAN, P.R. (1997) Interpreting aeromagnetic data in areas of limited outcrop. AGSO Joumal Of Australian Geology \& Geophysics, v. 17, n.2, p. 175-185.

HACHIRO, J.; COIMBRA, A.M.; MATOS, S.L.F. (1993) O caráter cronoestratigráfico da Unidade Irati. In: Simpósio sobre cronoestratigrafia da Bacia do Paraná,1. Rio Claro, 1993. Resumos, Rio Claro, IGCE-UNESP, p. 62-63.

HOBBS, B.E. (1976) An outline of structural geology. New York, Wiley \& Sons, 525p.

INSTITUTO DE PESQUISAS TECNOLÓGICAS DO ESTADO DE SÃO PAULO (IPT). (1981) Mapa geomorfológico do Estado de São Paulo, São Paulo. Escala 1:1.000.000, nota explicativa, v.1, $93 p$.

KING, L.C. (1956) A geomorfologia do Brasil oriental. Rev. Bras. de Geografia, v.18, n.2, p.147.

MATOS, S.L.F. (1995) O contato entre o Grupo Passa Dois e a Formação Pirambóia na borda leste da Bacia do Paraná no Estado de São Paulo São Paulo. São Paulo, 110 p. (Dissertação Mestrado) Instituto de Geociências, Universidade de São Paulo.

MATOS, S.L.F.; COIMBRA, A.M. (1997) Sucessão de fácies na Camada Porangaba, Grupo Passa Dois, Estado de São Paulo. Revista Brasileira de Geociências, v.27, p. 377-366.

MATTOS, J.T.; BALIEIRO, M.G.; SOARES, P.C.; BARCELLOS, P.E.; MENESES, P.R.; CSORDAS, S.M. (1982) Análise morfoestrutural com uso de imagens MSS/Landsat e Radar para pesquisa de hidrocarbonetos no Estado de São Paulo. INPE-2445-RTR/015. São José dos Campos, 170 p.

MCDOUGALL, I; HARRISON, T.M. (1999) Geochronology and thermochronology by the ${ }^{40} \mathrm{Ar} /{ }^{39} \mathrm{Ar}$ method. Oxford University Press, New York, 269p.

MELFI, A. (1967) Potassium-argon ages for core samples of basaltic rocks from Southern Brazil. Geochimica et Cosmochimica Acta, v. 31, p. 1079 - 1089.

MILLIGAN, P.R.; GUNN, P.J. (1997) Enhancement and presentation of airborne geophysical data. AGSO Journal of Australian Geology \& Geophysics, v. 17, n.2, p. 63-75.

MIZUTA, K.; CARVALHO, T.E.M.; TRIGUIS, J.A. (1983) Oil migration examples in Irati Formation, Parana Basin, Brazil. AAPG Bulletin, v. 67, p. 457.

NICKELSEN, R.P. (1974) Early jointing and cumulative fracture patterns. In: Utah Geological Association Publication, International Conference on the New Basement Tectonic, 1., Proceedings, 5:193-199.

NOGER, M.C. (1999) Tar-Sand Resources of Western Kentucky. Kentucky Geologic Survey, Reprint Series, Series XI, Reprint n.45, 27p. 
NORTHFLEET, A.A.; BETTINI,C.; CHAVES, H.A.F. (1971) Aplicação de geomatemática à prospecção de petróleo, análise de fraturas por poliedros ortogonais. In: CONGRESSO BRASILEIRO DE GEOLOGIA, 25, São Paulo, 1971. Anais. São Paulo, SBG, v. 3, p. 61 - 70.

OLIVEIRA, E.P. (1920) Rochas petroliferas do Brasil. Rio de Janeiro, Serviço Geológico e Mineralógico do Brasil, p.101-102.

OLIVEIRA, E.P. (1940) História da pesquisa de petróleo no Brasil. Rio de Janeiro, Serviço de publicidade agrícola, 208p.

OSSRN. (2003) Oil sands reclamation research network, Universidade de Alberta http://www.rr.ualberta.ca/oilsands/FAQs. htm\#hfmd

PARADELLA, W.R. (1998) Aplicações de sensoriamento remoto em geologia. Disciplina do curso de pós graduação em recursos minerais. Notas de Aula. São Paulo, Instituto de Geociências, Universidade de São Paulo.

PETRI, S. \& FÚLFARO V.J. (1983) Geologia do Brasil. 1 ed. São Paulo, EDUSP, 631. p.

PLICKA (1974) Observations on Joint Zones in Moravia, Czechoslovakia. New basement tectonics contribution, v. 30, p. 279-289.

QUADROS, L.P. \& SANTOS, A.S. (1980) Efeito das intrusões de diabásio sobre o conteúdo orgânico das rochas sedimentares. In: CONGRESSO BRASILEIRO DE GEOLOGIA, 31, Camboriú, 1980 Anais. Camboriú,SBG, v. 2, p. 410-422.

QUINTAS M.C.L. (1994) O embasamento da Bacia do Paraná: reconstrução geofísica de seu arcabouço. São Paulo, 218 p. (Tese - Doutorado) - Instituto de Astronomia e Geofísica, Universidade de São Paulo.

RAMOS, V. (1988) Late Proterozoic - Early Paleozoic of South América: a collisional history. Episodes, 11, 168-174.

RAMSAY, J.G.; HUBER, M.I. (1987) The techniques of modern structural geology: - folds and fractures. London, Academic Press, v. 2, 700 p.

RENNE, P. R.; ERNESTO, M.; PACCA, I.G.; COE R.S.; GLEN, J.M.; PRÉVOT, M.; PERRIN, M. (1992) The age of Paraná Flood Volcanism, Rifting of Gondwanaland, and the JurassicCretaceous Boundary. Science, v. 258, p. $975-979$.

RICCOMINI, C.; CHAMANI, M.A.C.; AGENA, S.S.; FAMBRINI, G.L.; FAIRCHILD, T.R.; COIMBRA, A.M. (1992) Earthquake-induced liquefaction features in the Corumbatai Formation (Permian, Paraná Basin, Brazil) and the dynamics of Gondwana. Anais da Academia Brasileira de Ciências, v.64, p. 210.

RICCOMINI, C. (1995) Tectonismo gerador e deformador dos depósitos sedimentares pósgondvânicos da porção centro-oriental do estado de São Paulo e áreas vizinhas. São Paulo, 100 p. (Tese Livre-docência) - Instituto de Geociências, Universidade de São Paulo.

ROCHA-CAMPOS A.C., CORDANI U.G., KAWASHITA K., SONOKI H.M., SONOKI I.K. (1988) Age of Paraná Flood Vulcanism. In: E.M. Picirillo \& A. Melphi (eds). The Mesozoic flood basalts of the Paraná Basin: petrogenetic and geophysical aspects. São Paulo, Instituto Astronômico e Geofísico - USP, 600 p.

ROSS, J.L.S. \& MOROZ, I.C. (1997) Mapa geomorfológico do Estado de São Paulo. Laboratório de Geomorfologia, Depto. de Geografia, FFLCH, USP/ Laboratório de Cartografia Geotécnica, Geologia Aplicada, IPT/ Fapesp, Fundação de Amparo à Pesquisa do Estado de São Paulo, Relatório 64 p. (escala 1:500.000).

ROSSELO, E.A.; MASSABIE, A.C.; LÓPEZ-GAMUNDI, O.R.; COBBOLD, P.R.; GAPAIS, D. (1997) Late Paleozoic transpression in Buenos Aires and northeast Patagonia ranges, Argentina. Journal of South Americam Earth Sciences, v.10, n. 5-6, p. 389-402. 
ROSTIROLLA, S. P.; ASSINE, M.L.; FERNANDES, L.A \& ARTUR, P.C. (2000) Reativação de paleolineamentos durante a evolução da Bacia do Paraná - O exemplo do Alto Estrutural de Quatiguá. Revista Brasileira de Geociências, v. 30, p. 639 - 648 .

SÁ, N.C. (1994) Redução de observações gravimétricas: teoria e prática. Apostila de aula. IAG, Universidade de São Paulo, 90 p.

SANTOS, A.R. (1986) Estudos sobre a tectônica de fraturamento na região do quadrilátero ferrifero e em partes do complexo migmatito-granulitico de Minas Gerais, com base em sensoriamento remoto. São Paulo, 172 p. (Tese - Doutorado) - Instituto de Geociências, Universidade de São Paulo.

SANTOS, R.V.; DANTAS, E.; ALVARENGA, C.J.S.; BEDRAN, F.; REIS, W.; GUIMARÃES, E.M.; OLIVEIRA, C.G.; MARQUES-TOIGO, M.; MENDONÇA FILHO, J.G.; REIS, C.W.D.; MEDEIROS, S.R. (2003) Geochemical and thermal effects of basic intrusive rocks on sediments from the Irati Formation - Northwestern Paraná Basin. In: SOUTH AMERICAN SYMPOSIUM ON ISOTOPE GEOLOGY, 4, Salvador, 2003. Short Papers, Salvador, v.3, p.776.

SCHOBBENHAUS, C.; CAMPOS, D.A.; DERZE, G.R.; ASMUS, H.E. (1984) Geologia do Brasil. Texto explicativo do Mapa Geológico do Brasil (escala = 1:2.500.000), DNPM, $501 \mathrm{p}$.

SIMONEIT, B.R.T.; BRENNER, S.; PETERS, K.E.; KAPLAN, I.R. (1978a) Thermal alteration of Cretaceous black shale by basaltic intrusions in the eastern Atlantic. Nature, v. 273, p. 501-504.

SIMONEIT, B.R.T.; BRENNER, S.; PETERS, K.E.; KAPLAN, I.R. (1978b) Thermal alteration of Cretaceous black shale by basaltic intrusions in the eastern Atlantic - II. Effects on bitumen and kerogen. Geochimica et Cosmochimica Acta, v. 45, p.1581-1602.

SOARES, P.C. (1973) O Mezosóico Gonduânico no Estado de São Paulo. Rio Claro, 152 p. (Tese Doutorado) - Departamento de Geologia e Mineralogia da Faculdade de Filosofia, Ciências e Letras de Rio Claro.

SOARES, P.C. (1974) Elementos estruturais da parte nordeste da Bacia do Paraná: Classificação e Gênese. In: CONGRESSO BRASILEIRO GEOLOGIA, 28, Porto Alegre, 1974. Anais, Porto Alegre, SBG, v. 4, p. 107-121.

SOARES, P.C.; FIORI, P. (1976) Lógica e sistemática na análise e interpretação de fotografias aéreas em geologia. Noticia Geomorfológica, v. 16, n. 32, p. 71-40.

SOUZA, R.G. (1997) Petróleo - Histórias das descobertas e o potencial brasileiro. Muiraquitã, Niterói, $272 p$.

STEVEAUX, J.C.; SANTOS, M.V.; SEIGNEMARTIN, C.L. (1980) Geologia do bloco 49, balizado pelas cidades de Avaré, Itapeva e Itapetininga. São Paulo, Paulipetro CESP/IPT, 90p. (Relatório BP-016/80)

STEWART, K.; TURNER, S.; KELLEY, S.; HAWKESWORTH, C.; KIRSTEIN, L.; MANTOVANI, M. (1996) 3-D, ${ }^{40} \mathrm{Ar}-{ }^{39} \mathrm{Ar}$ geochronology in the Paraná continental flood basalt province. Earth and Planetary Science Letters, v. 143, p.95-109.

TANKARD, A.J.; ULIANA, M.A.; WELSINK, H.J.; RAMOS, V.A.; TURIC, M.; FRANÇA, A.B.; MILANI, E.J.; BRITO NEVES, B.B.; EYLES, N.; SKARMETA, J.; SANTA ANA, H.; WIENS, F.; CIRBIAN, M.; LÓPEZ PAULSEN, O.; GERMS, G.J.B.; DE WIT, M.J.; MACHACHA, T.; MCG. \& MILLER, R. (1995) Structural and Tectonic controls of basin evolution in southwestern Gondwana during the Phanerozoic. Américan Association of Petroleum Geologists Memoir, 62, 5-52.

THOMAZ FILHO, A. (1982) Ocorrência de arenito betuminoso em Anhembi (SP) - cubagem e condicionamento geológico. In: CONGRESSO BRASILEIRO GEOLOGIA, 37, Salvador, 1982. Anais, Salvador, SBG, v. 5, p. 2344-2348. 
TRIGUIS, J.A. (1986) An organic geochemical investigation of heat-effected sediments in the Paraná Basin (Brazil). Newcastle, UK, 140p. (Tese - Doutorado) - University of Newcastle Upon Tyne.

TURNER, S.; REGELOUS, M.; KELLEY, S.; HAWKESWORTH, C.; MANTOVANI, M. (1994) Magmatism and continental break-up in the South Atlantic: high precision ${ }^{40} \mathrm{Ar}-{ }^{39} \mathrm{Ar}$ geochronology. Earth and Planetary Science Letters, v. 121, p. 333-348.

UNDERHILL, J.R. \& WOODCOCK, N.H. (1987) Faulting in high-porosity sandstones; Red Sandstone, Arran, Scotland. In: Jone, M.E. \& Preston R.M.F., 1987, Deformation of Sediments and Sedimentary Rocks. Geological Society Special Publication n. 29, p. $91-105$.

VASCONCELLOS, R.M.; METELO, M.J.; MOTTA, A.C.; GOMES, R. D. (1994) Geofísica em levantamentos geológicos no Brasil. CPRM, Rio de Janeiro, 165p.

VENEZIANI, P. (1987) Análise de movimentos da tectônica rúptil e rúptil-dúctil através da interpretaçâo de produtos de sensores remotos na região do espinhaço meridional (mg): uma correlação com processos evolutivos. São Paulo, 186 p. (Tese - Doutorado) - Instituto de Geociências, Universidade de São Paulo, São Paulo.

WASHBURNE, C.W. (1930) Geologia do Petróleo do Estado de São Paulo. Rio de Janeiro, Departamento Nacional de Produção, Mineral Ministério de Agricultura, 228 p.

YOSHIDA, R. \& GAMA, JR. E. (1982) Geologia da Bacia do Paraná: reavaliação da potencialidade e prospectividade em hidrocarbonetos. In: Geologia da Bacia do Paraná - Reavaliação da Potencialidade e Prospectividade em Hidrocarbonetos. São Paulo, Paulipetro/CESP/IPT, p. 1 17.

ZALAN, P.V.; WOLFF, S.; CONCEIÇÃO, J.C.J.; ASTOLFI, M.A.M.; VIEIRA, I.S.; APPI, V.T.; ZANOTTO, A.; MARQUES, A. (1991) Tectonics and sedimentation of the Parana Basin. In: GONDWANA SEVEN PROCEEDINGS. São Paulo, Instituto de Geociências - USP, p. 83-117. 